\title{
"A statesmanlike measure with a partisan tail": The Development of the Nineteenth-Century Dominion Electoral Franchise
}

\author{
by \\ Colin J. Grittner, BHum
}

\begin{abstract}
A thesis submitted to
the Faculty of Graduate Studies and Research

in partial fulfillment of

the requirements for the degree of
\end{abstract}

Master of Arts

Department of History

Carleton University

Ottawa, Ontario

29 June, 2009

(C) copyright

2009, Colin J. Grittner 


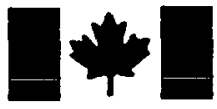

Library and Archives

Canada

Published Heritage

Branch

395 Wellington Street

Ottawa ON K1A ON4

Canada
Bibliothèque et

Archives Canada

Direction du

Patrimoine de lédition

395, rue Wellington

Ottawa ON K1A ON4

Canada
Your file Votre refférence
ISBN: $978-0-494-60310-9$
Our file Notre reference
ISBN: $978-0-494-60310-9$
NOTICE:

The author has granted a nonexclusive license allowing Library and Archives Canada to reproduce, publish, archive, preserve, conserve, communicate to the public by telecommunication or on the Internet, loan, distribute and sell theses worldwide, for commercial or noncommercial purposes, in microform, paper, electronic and/or any other formats.

The author retains copyright ownership and moral rights in this thesis. Neither the thesis nor substantial extracts from it may be printed or otherwise reproduced without the author's permission.
AVIS:

L'auteur a accordé une licence non exclusive permettant à la Bibliothèque et Archives Canada de reproduire, publier, archiver, sauvegarder, conserver, transmettre au public par télécommunication ou par l'Internet, prêter, distribuer et vendre des thèses partout dans le monde, à des fins commerciales ou autres, sur support microforme, papier, électronique et/ou autres formats.

L'auteur conserve la propriété du droit d'auteur et des droits moraux qui protège cette thèse. $\mathrm{Ni}$ la thèse ni des extraits substantiels de celle-ci ne doivent être imprimés ou autrement reproduits sans son autorisation.
In compliance with the Canadian Privacy Act some supporting forms may have been removed from this thesis.

While these forms may be included in the document page count, their removal does not represent any loss of content from the thesis.
Conformément à la loi canadienne sur la protection de la vie privée, quelques formulaires secondaires ont été enlevés de cette thèse.

Bien que ces formulaires aient inclus dans la pagination, il n'y aura aucun contenu manquant.

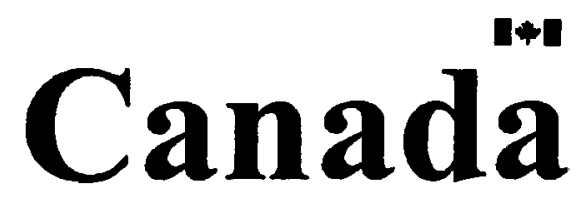




\begin{abstract}
In Canada, the vote represents the principal avenue for political participation. Between Confederation in 1867 and the end of the nineteenth century, Canada's federal franchise law - the law that determines who may vote in Dominion elections - underwent a series of seemingly antithetical alterations. Thus far, historians and political scientists have written very little on this development of the nineteenth-century Dominion franchise. Amongst those who have, the idea that franchise reform took place during this period because of partisan expediency has tended to hold sway historiographically. Taking other factors into account - from political altruism to popular pressure - this thesis questions that historiographical trend. Certainly, partisanship still played a part in these legislative alterations. Through an application of state formation theory, this thesis argues that nineteenth-century Canadian statesmen, by means of new franchise law, in large part attempted to graft their own ideological visions of Canada onto the burgeoning nation.
\end{abstract}




\section{Acknowledgements}

This thesis would have never reached its completion without the generous support of those around me. I must first thank my parents for all they have done. Aside from reading drafts and acting as a sounding board for my zany ideas, they unfailingly provided encouragement and motivation whenever I needed it. I am similarly grateful to my family and friends. If I managed to stay grounded while undertaking this project, I have them to thank for it. Many thanks must also go to my supervisor at Carleton University, Professor Duncan McDowall. Whatever I required, whatever my concern, I could always count on Prof. McDowall to provide a friendly ear and sage advice. I would also like to thank Professors Norman Hillmer and John Walsh for keeping their doors open to me and challenging me to push my work further. I must also extend a thank you to Joan White for helping steer me through the woolly world of graduate studies. Lastly, I would like to thank both SSHRC and the Ontario Graduate Scholarship program for their confidence in and financial support of this project.

Before it begins in earnest, I would like to dedicate this thesis to my grandmother, Alice Grittner. One of the toughest (yet kindest) people I have ever known, she sadly passed away just before this project got underway. Her memory has helped push me through whatever obstacles fell before me, no matter how insurmountable or unpleasant they may have appeared. Thanks Granny. 


\section{Table of Contents}

Abstract

Acknowledgements

ii

Table of Contents

iii

List of Figures

Chapter 1 "The Canadian franchise was a neglected field": $\quad 1$ Introduction, Historiography, and Methodology

Chapter 2 "Every man who now has a vote...should continue to have a vote": The Confederation Franchise of 1867

Chapter 3 "It is conservative in its very essence":

The Electoral Franchise Act of 1885

Chapter 4 "In no two cases...do you find the same franchise apply": 


\section{List of Figures}

Page

“A Bird's-Eye View" $\quad 115$

"The Triple Alliance" 133 


\section{Chapter 1}

\section{"The Canadian franchise was a neglected field": Introduction, Historiography, and Methodology}

On June 18, 1886, at nine o'clock in the morning, Judge Edward Morgan opened the court of final revision for divisions four, five, six, and seven of East York in Davisville, Ontario. ${ }^{1}$ In front of the judge appeared delegations for both the Conservative and Reform parties, led respectively by lawyers Alfred Boultbee and John A. Paterson, their witnesses, contingents of party loyalists, and individuals hoping to receive the federal vote. ${ }^{2}$ The previous year, Prime Minister John A. Macdonald's Conservative government had rewritten Canada's federal electoral franchise legislation. The new Dominion Franchise Act removed jurisdiction over the federal franchise from the provincial sphere and placed it under the sole control of the Dominion Parliament, thereby instituting new qualifications for voting in federal elections. Consequently, the Dominion government needed to establish afresh precisely who could elect

\footnotetext{
${ }^{1}$ Born in St. Vincent, Wisconsin, in 1838, Edward Morgan came to Canada with his father in 1854. Originally a Newmarket, Ontario solicitor, he was appointed as junior judge for York County on September 15, 1885. As of 1912, he still resided in Toronto. See: "Morgan, His Honour Edward," The Canadian Men and Women of the Time, ed. Henry James Morgan (Toronto: William Briggs, 1912 ), 821. When drawing up voters' lists - the lists that named individuals who could legally vote in a given election - the revising barrister (the person responsible for this process) would hold courts of final revision. There, individuals could make their case as to who should or should not receive the vote in a given election. After such a court took place, and the resultant changes to the voters' lists made, no other alterations would take place before election day.

2 "East York," Toronto Globe, 19 June 1886, 14. Born near Southampton, England in 1828, Alfred Boultbee was called to the Ontario bar in 1855. A Conservative, he served as York North's Member of Provincial Parliament from 1872 until he resigned in 1875 to contest a federal by-election for the same riding. Although he failed in this instance, he was elected under the Conservative banner as Member of Parliament for York East in 1878. While he was not reelected in 1882, he remained a Conservative supporter until his death in 1901. See: Richard Boultbee, "Alfred Boultbee (1828 - 1901)," The History of the Boultbee Family (2005), <http://homepage.ntlworld.com/boultbee/bfh/alfredb.htm> (17 October 2008). Born in Scotland on the Isle of Lewis in 1846, John Andrew Paterson received his education at the University of Toronto. Also a lawyer by trade, he lived and practiced in Toronto as well. See: "Paterson, John Andrew," The Canadian Men and Women of the Time, 885.
} 
representatives to the House of Commons. ${ }^{3}$ As the revising barrister for East York, it fell to Judge Morgan to finalize the constituency's federal voters' list before the impending winter election. ${ }^{4}$

Arthur and James Acey, a pair of brothers who resided in Division Five of the constituency, submitted two of the first applications heard by Judge Morgan that day. ${ }^{5}$

The Acey brothers were farmers. Not possessing land of their own, the two still lived on the family farm with their aging father, John Acey. ${ }^{6}$ To gain their livelihood, they helped him with the farm's upkeep. According to the new franchise act, all sons of farmers who had reached the age of majority of twenty-one, and whose fathers owned farms worth at least $\$ 150$, could exercise the vote. ${ }^{7}$ Unfortunately for the junior Aceys, while they had both reached the age of majority, John Acey did not own his farm. He was a tenant farmer. ${ }^{8}$ Under Ontario's franchise law - the legislation used to regulate the federal franchise in Ontario before January 1, 1886 - the fact that the senior Acey rented his land would not have posed a problem. Ontario viewed all farmers' sons as equals with respect to the franchise. ${ }^{9}$ If the federal franchise had remained unaltered, the Acey brothers could have therefore happily cast their ballots at the next federal election. Despite the exhortations of John A. Paterson on the Aceys' behalf, the new act was clear. As the

\footnotetext{
${ }^{3}$ See: Elections Canada, A History of the Vote in Canada (Ottawa: The Minister of Public Works and Government Services Canada, 1997), 48-49.

${ }^{4}$ Each constituency would have had its own revising barrister. His task was to draw up and finalize the constituency's voters' list. As such, he most directly determined who could and could not vote in a given election. Judge Morgan received his appointment soon after his call to the bench. See: The Canadian Men and Women of the Time, 821.

5 "East York," Toronto Globe, 19 June 1886, 14.

${ }^{6}$ Bruce S. Elliott, ed, Index to the 1871 Census of Ontario: York (Toronto: Ontario Geneological Society, 1992), 1. According to the census record, John Acey had moved to Canada from England. Even as early as 1871 he lived and farmed in East York. See: Ibid.

${ }^{7}$ Thomas Hodgins, The Canadian Franchise Act (Toronto: Roswell \& Hutchison, 1886), 87-88.

8 "East York," Toronto Globe, 19 June 1886, 14.

${ }^{9}$ Ibid.
} 
sons of a tenant farmer, Judge Morgan had no choice but to keep Arthur and James Acey off of East York's voters' list. ${ }^{10}$ As a result of Prime Minister Macdonald's franchise act, they had become disenfranchised: they no longer had a voice in Canada's federal elections.

Today in Canada, the Acey brothers would have never found themselves in the situation they faced in 1886. As guaranteed by the Charter of Rights and Freedoms, all Canadian citizens who have reached the age of majority (which has since been lowered to the age of eighteen) have the unalienable right to vote in Canada's federal elections. Indeed, the income and property qualifications for enfranchisement that struck the Aceys from the federal voters' list have not existed federally since 1920 . During the nineteenth century, however, Canada's Dominion franchise had nowhere near the same inclusiveness and stability. As the Acey clan worked the land in hopes of sustaining itself and providing for its future, Canadians from across the country struggled to frame the ultimate shape of the nation's franchise. Canada's would-be electors formed a strikingly discordant chorus. Opinions varied greatly and individuals championed a myriad of different franchises: ones controlled by the Dominion government, and ones governed by the provincial legislatures; ones based on the principle of 'one person one vote,' and ones that allowed multiple votes cast by the same person; ones with every sort of qualification imaginable (such as property, income, taxation, and education qualifications, to name a few), and ones with no qualifications whatsoever. While manhood suffrage gained in popularity as the twentieth century approached, dialogue rooted in the language of exclusion never fully left the late nineteenth-century debate.
${ }^{10} \mathrm{Ibid}$. 
These deliberations in fact stretched from Confederation in 1867 down to the end of the nineteenth century. Canada's federal franchise and its legislative foundation consequently underwent a series of seemingly antithetical alterations. In 1867 , a very restrictive, property-based set of provincially-controlled franchises denied the vote to the majority of Canadian men and all Canadian women. (There were also other exclusions rooted in race). By the beginning of the twentieth century, however, authority over the Canadian franchise had changed hands twice over: from the provincial governments to the federal government in 1885 ; then, in 1898 , back to the provinces once again. During this strange revolution of removal and reinstatement, the restrictive franchise initially became less strict, which in turn gave way to a resurgently restrictive, if not more restrictive, franchise in 1885 . By 1898 , however, a franchise that closely resembled manhood suffrage was embraced throughout most of Canada.

This convoluted and contradictory string of legislative and jurisdictional changes begs a series of questions. First, what political and social ideologies precipitated such antithetical changes to the nineteenth-century Dominion electoral franchise? Were the shifts prompted by philosophical inclinations or political expediency? Who desired and who initiated such changes? How great an influence did the public have in compelling their elected representatives to legislate these changes? How did Canada's political parties, social groups, and economic classes react to newly-enacted franchise legislation? And, lastly, how did these reactions affect subsequent political dialogue and legislation? The following study will attempt to answer these questions to better understand why Canada's nineteenth-century franchise legislation developed in the peculiar way it did. 
Historically within Canada, the franchise has acted as the cornerstone to the nation's democratic system of governance. It has represented, and still represents, the principal avenue by which Canadian citizens participate in the governance of the Canadian state. As the Acey brothers would have understood when election day arrived in 1887 , individuals without the franchise have no direct means of influencing the course of government and, consequently, the nation itself. Despite the importance of enfranchisement to Canada's democratic underpinnings, it has not nearly received its due attention from Canadian scholars. The vote and its regulation are generally treated as 'givens' of Canadian political history. As early as 1968, Canadian historian and social critic Frank Underhill identified Canadian electoral franchise studies as a sadly "neglected field" in the realm of historical scholarship. ${ }^{11}$ He had a very sound basis for his lament. By that time, Canadian historians and political scientists had combined to publish a grand total of thirty-one pages of analysis in their attempts to explain the whole of Canadian franchise reform! Of course, the literature on nineteenth-century Canadian federal franchise development represents a mere fraction of these thirty-one pages. The fractious years of 1917 to 1920 - with all the excitement of wartime elections, women's suffrage, and Prime Minister Robert Borden's gerrymandering - have more successfully riveted the attention of Canada's franchise scholars. In the forty years that have passed since 1968, the scholarship on nineteenth-century Canadian suffrage has admittedly expanded, if only slightly. The Canadian government has published one factual compendium of Canadian franchise law. A few, rather brief explanations of individual franchise acts have emerged. The abuse of the franchise has attracted the attention of

${ }^{11}$ John Garner, The Franchise and Politics in British North America 1755-1867 (Toronto: University of Toronto Press, 1969), preface. 
nineteenth-century political historians; but virtually no one has presented the franchise in normative terms. Scholars have attempted to examine how suffrage reform and electoral law affected particular groups of Canadians, and the nineteenth-century federal elections themselves. These analyses, while intriguing, unfortunately have not filled the gap in the historiography. So far, no one has yet to fully and thoroughly explain nineteenth-century Dominion franchise reform in a sequential and systematic fashion.

While pioneering University of Toronto historian George M. Wrong briefly mentioned the federal extension of the vote to women in his Canadian institutional history of 1938 , the first scholarly attempt to analyze Canadian franchise development arrived in 1943. ${ }^{12}$ At the Canadian Historical Association meeting of that year, then University of Manitoba historian W. L. Morton presented his very brief, ten-page essay entitled "The Extension of the Franchise in Canada: A Study in Democratic Nationalism." As the title suggests, Morton's principal interest in his paper stretches beyond electoral franchise development. Instead, he views the franchise as a way to measure the ascendency of democracy in Canada and the rate of its acceptance. To support his argument that "democracy...came to Canada almost by stealth," Morton cites that franchise extension has never been "a major political issue in any part of Canada."13 Indeed, he claims that franchise reforms neither met any sort of popular demand nor received anything beyond a placid "lukewarm" acceptance from the Canadian public. ${ }^{14}$

\footnotetext{
${ }^{12}$ George M. Wrong, The Canadians: A Story of a People (Toronto: Macmillan, 1938), 403-404. Amongst other early professional histories of Canada, Canada and its Provinces stands out. A massive twenty-three volume series published between 1914 and 1917, it was presided over by historian Adam Shortt and Canada's first federal archivist, Arthur G. Doughty. Despite its considerable size and scope, it makes no mention of the franchise whatsoever.

${ }^{13}$ W. L. Morton, "The Extension of the Franchise in Canada: A Study in Democratic Nationalism," Report (Canadian Historical Association, 24-25 May 1943), 73.

${ }^{14}$ Ibid., 78-79.
} 
Since Morton categorically dismisses any kind of bottom-up explanation for Canadian franchise expansion, what inspired such reforms? For Morton, political ideology and, to a lesser extent, crass partisan benefit, provide the answers to this question. ${ }^{15}$

In his paper, Morton portrays Canada's two nascent nineteenth-century political parties - the Liberals and the Conservatives - in ideologically contrasting terms. He describes the Liberals, on one hand, as defenders of democratic advance and provincial autonomy. As a result, they reportedly advocated franchise expansion and provincial control of suffrage legislation. ${ }^{16}$ On the other hand, Morton argues that the Conservatives resisted popular sovereignty (which they saw as leading to mob rule) and vehemently supported the notion of a strong centralized federal government. The Conservatives therefore wished to maintain a restricted franchise controlled by the federal government in Ottawa. ${ }^{17}$ While Morton acknowledges more partisan party interests must have had some effect, he depicts ideological motivations as playing the lead role in moulding the various nineteenth-century franchise reforms. For example, he argues that the restrictive Confederation franchise stemmed from engrained mid-nineteenth-century Conservative values because its legislators designed it to resist the spread of popular democracy. ${ }^{18}$ Similarly, he cites that the Conservative franchise act of 1885 unmistakably "preserved the ascendency of conservative principles and, no doubt, the Conservative party" because it restricted the vote and nationalized the electoral lists. ${ }^{19}$ Morton makes similar

\footnotetext{
${ }^{15}$ In this study, terms such as "partisan benefit" and "partisan party interest" (for lack of a better phrase) describe actions motivated by a political party's desire to either attain power, stay in power, or exploit its power.

${ }_{16}^{16}$ Ibid., $75 ; 77$.

${ }^{17}$ Ibid., 76-77.

${ }^{18}$ Ibid., 76.

${ }^{19}$ Ibid., 77.
} 
ideological implications concerning the Franchise Act of 1898, only this time he sees no involvement of partisan influence whatsoever. He argues this Liberal act seemingly put Liberal reformist philosophy into practice because it returned control of federal franchise legislation to the provinces, which had since all lowered their franchise qualifications, many to the point of manhood suffrage. ${ }^{20}$ The correlations that Morton draws between ideology and legislation represent the strength of his paper. Unfortunately, the paper contains significant deficiencies as well. The largely unsubstantiated discussion of partisan benefit gives it the appearance of a hurried afterthought. Even more conspicuously, the article completely dismisses any notion of public influence over legislation without providing a shred of proof. Morton's generalization is perhaps understandable: he originally designed the paper as a short conference presentation, and not as a full-blown academic article. Still, these glaring liabilities hinder the article's explicative power. While Morton laudably provided a starting point for historical research on the Canadian federal electoral franchise, the incompleteness of his work left the door wide open for future studies.

Within seven years of Morton's essay, University of Saskatchewan political scientist Norman Ward forwarded his own investigation of Canadian franchise reform (thus beginning the trend of political scientists overtaking the historical study of the Canadian franchise, a trend that continues today). His study was also quite short, only spanning a chapter in a larger text on Canadian political institutions. ${ }^{21}$ Despite this brevity, Ward covers eighty-one years of Canadian franchise history starting with

\footnotetext{
${ }^{20}$ Ibid., 77-78.

${ }^{21}$ Norman Ward, The Canadian House of Commons: Representation (Toronto: University of Toronto Press, 1950). See: Chapter XII - "The Franchise", 211-232.
} 
Confederation in 1867 . He does so by focusing on the franchise acts passed during this period. Taking a page from Morton, Ward suggests that party ideology played a role in nineteenth-century Canadian franchise development. For example, he argues that the Conservatives nationalized the federal franchise in 1885 as part of their belief in a strong federalist political structure for Canada. ${ }^{22}$ Ward also contends that the Liberals may have passed 1898's franchise reform under ideological auspices as well; in deference to their "faith in provincial autonomy," they supposedly reversed the Conservative Act and provincialized the federal vote. ${ }^{23}$ Laurier's franchise was thus a triumph of provincial rights. Taking another page from Morton, Ward contends that the desire for partisan benefit permeated and encouraged nineteenth-century franchise reform as well. At this point, however, their opinions begin to diverge.

In comparison with Morton, Ward places much more emphasis on partisan benefit, and political expediency more generally, as explanatory factors. For Ward, the form of Canada's first franchise had more to do with pragmatism than anything else. While "Section 41 of the British North America Act, 1867, provided for the continued use of provincial franchises," Ward argues that the Fathers of Confederation preferred a unified, federally-governed franchise. They supposedly employed the existing provincial franchises simply because "it was impracticable [for the first Canadian Parliament] to use anything" else. ${ }^{24}$ To Ward, this political expediency shifted more towards an expediency for partisan benefit as the nascent Parliament began to establish itself. By 1885, the Conservatives had supposedly set their eyes on legislatively swinging future federal
${ }^{22}$ Ibid., 211.
${ }^{23}$ Ibid., 224.
${ }^{24}$ Ibid., 211. 
elections in their favour. According to this argument, the Conservatives must have also pushed their 1885 reform through the Commons to both disenfranchise potential Liberal voters (who had previously gained the franchise through predominantly Liberal provincial franchise legislation) and to enfranchise other groups of Canadians who, they hoped, would vote Conservative out of gratitude. ${ }^{25}$ For the 1898 act, Ward argues that the Liberals had the same idea, but with a reverse rationalization. They also hoped that their legislation's expansion of the franchise would create a new, loyal electoral base. Moreover, he goes on to claim that provincial politics may have helped induce the Liberals to return control over the franchise to the provinces. Since Liberal governments governed most provinces in 1898 , the federal Liberals reportedly believed they could legislatively bring provincial election machinery to their aid as well. ${ }^{26}$

Through these arguments, Ward made two significant additions to Canadian franchise historiography. First, he forwarded an expediency argument concerning 1867's federal franchise that nicely counterbalances Morton's ideology argument. Second, and perhaps more importantly, he greatly reinforced Morton's partisan benefit argument. Of the two perspectives, scholars have since drawn upon this second interpretation the most. In fact, Ward's expanded partisan benefit argument still holds up as the foundation for the majority of today's nineteenth-century Canadian federal franchise studies (as we shall see). Yet, toward the end of his analysis, Ward provides a curious twist to his treatment of franchise reform. He introduces another motivation that Morton had completely dismissed: that of public opinion. In doing so, he gave agency to the people - something that Canada's old nationalist historians seldom did.

\footnotetext{
${ }^{25}$ Ibid., 215-216.

${ }^{26}$ Ibid., 224.
} 
Ward sees public opinion as a present but minor contributor to suffrage development during this period. Although he does not mention it in connection with the acts of 1867 or 1885 , he does argue that a "rise in [public] pressure to force the wider franchise on the federal government" had emerged by $1898 .{ }^{27}$ Yet, like Morton, Ward takes his pronouncement about public opinion as a given. He provides no evidence to corroborate it. While the reader may have been able to forgive Morton's generalization because of his particular forum, it proves less easy to do so in the case of Ward. He could have easily expanded his chapter by the few necessary pages for such a discussion. A lack of interest, or a lack of knowledge, may have prevented this examination of extragovernmental sentiment (a possibility with Morton as well). When Ward wrote his text in the early 1950s, institutional histories and political biographies still represented the "dominant form[s] of historical writing." ${ }^{28}$ The 'new histories' - beginning with social history and its attempt to recapture the 'average' person's life - did not attain any sort of popularity until the next decade. Gender history, labour history, and cultural history developed even later. Without a strong social history tradition to guide him, Ward may have not seen the need to more closely investigate the average Canadian's opinion. And even if he had such an interest, he certainly did not have the tools to do so. Because he wrote in 1950, he did not have access to the propositions, methodologies, and raw data later developed and espoused by the new historians to discover public sentiment. Nor could he access theories on state formation and the public sphere eventually assimilated into the new histories from the social sciences. As a result, he had little prospect to provide a complete explanation as to why the nineteenth-century Canadian suffrage

\footnotetext{
${ }^{27}$ Ibid., 224.

${ }^{28}$ Carl Berger, The Writing of Canadian History (Toronto: Oxford University Press, 1976), 160.
} 
developed in the way that it did. True, Ward opened a new avenue of inquiry for Canadian franchise studies: the Canadian public now apparently played at least some role in franchise reform. As with Morton's study, however, unanswered questions prevented a satisfactory account of Canada's nineteenth-century federal franchise development.

Following the publication of Ward's analysis, a lull fell over this particular line of inquiry. In 1955, former University of Toronto historian Donald Creighton briefly mentioned federal franchise reform as part of his magisterial biography of John A. Macdonald. While he viewed the passage of Macdonald's franchise act as a testament to "the old man's expertise in the fine points of parliamentary in-fighting", Creighton offered little explanation as to the act's necessity aside from the notion that Macdonald "disliked the fact that federal elections were held in accordance with franchises determined by the different provincial legislatures."29 Thirteen years later, in 1968, Dalhousie political scientist J. Murray Beck advanced his own discussion of Canadian electoral history. Containing perhaps the sole compilation of Dominion election statistics, Pendulum of Power follows a blow-by-blow account of Canada's federal elections from 1867 to 1968 . Although obviously interested in the vote and its results, Beck on the other hand never seeks to investigate its underpinnings. He therefore tended to ignore the franchise, unless it became an election issue (as it did in 1917) ${ }^{30}$

${ }^{29}$ Donald Chreighton, John A. Macdonald: The Old Chieftan (Toronto: Macmillan, 1955), 427; 407.

${ }^{30}$ J. Murray Beck, Pendulum of Power (Scarborough: Prentice-Hall, 1968), 139. Of course, Canadian women (admittedly, only "the close female relatives of persons on active duty overseas") in 1917 received the federal vote for the first time. The War-Time Elections Act would also "deny the vote to naturalized immigrants en bloc". According to Beck, Prime Minister Borden's Union government won at least fourteen seats because of this alteration of the Dominion franchise. See: Ibid., 139; 145. 
The year after Pendulum of Power hit the bookstores, the University of Toronto Press published The Franchise and Politics in British North America 1755-1867 by former University of Manitoba political scientist John Garner. Despite the inclusion of "1867" in the title, the text does not expand its investigation beyond the British North American colonial franchises. Admittedly, his opening chapter does provide some indication as to colonial sentiments regarding enfranchisement during the 1860 s, such as a general belief that a restricted franchise would prevent the excesses of unbridled popular democracy witnessed in the United States. ${ }^{31}$ Nonetheless, Garner does not connect these opinions to Confederation and the structure of Canada's inaugural suffrage legislation. An investigation of nineteenth-century Canadian franchise reform must make these connections. While University of New Brunswick historian Gail G. Campbell would later test some of Garner's assumptions concerning franchise restrictiveness using Albert County, New Brunswick as a case study, her study did not chronologically proceed any further than the late-1850s. ${ }^{32}$ Even so, Campbell urges historians of the franchise to adopt a more balanced approach to their subject. While franchise reforms sometimes "came as a result of contests for influence among competing elites", she argues that they just as often came as "a response to pressures from below". 33 In light of

${ }^{31}$ Garner, 7. More generally, see: Garner, 3-10.

${ }^{32}$ More specifically, Campbell suggested a reevaluation of Garner's claim that "'no numerous and important segment of the [adult male] population' was excluded from the exercise of the franchise in any of the six colonies he examined." In her conclusion, she argues that Garner was ultimately correct in his assessment concerning the breadth of the colonial franchises considering the suffrage was "a right that the vast majority of young men could realistically expect to gain, and to gain legally." On the other hand, Campbell did disagree with Garner's conclusion "that a broad franchise necessarily meant that the law and the reality diverged in any truly significant way." See: Gail G. Campbell, "The Most Restrictive Franchise in British North America? A Case Study", Canadian Historical Review 71.2 (June 1990), 160; 187-188. This study will comment upon Campbell's article more fully in the following chapter.

${ }^{33}$ Ibid., 159. 
the generally one-sided arguments concerning franchise reform that preceded her study, Campbell's point is well taken.

Around the same time, University of British Columbia political scientist R. Kenneth Carty, and his colleague social historian W. Peter Ward, published an edited volume on national politics in Canada. In it, they employed a scant two pages of their study of the making of Canada's political community to analyze the entirety of nineteenth-century Canadian suffrage. In repackaging Norman Ward's political expediency and partisan benefit arguments for a new generation of scholars, they did not really add anything new to the historiography. ${ }^{34}$ Similarly, in 1993, Brock University political scientist Garth Stevenson included a couple of pages about "Canadian attitudes toward democracy and the evolution of the franchise" in his monograph on federalprovincial relations in Canada entitled Ex Uno Plures. ${ }^{35}$ Unfortunately, Stevenson does not offer the reader any sort of exegesis of this evolution, aside from a rather enigmatic remark that links the Electoral Franchise Act of 1885 to a supposed practical acceptance of democracy by Prime Minister Macdonald. ${ }^{36}$ To find the next sizeable inquiry into Canadian federal franchise evolution, one must therefore leap ahead to 1997. In that year, Canada's Chief Electoral Officer, Jean-Pierre Kingsley, sponsored the publication of $A$ History of the Vote in Canada. Based largely on the research of University of Montreal political scientist Louis Massicotte, it traces the evolution of suffrage and, more broadly, responsible government from 1758 - when Nova Scotia elected the first

\footnotetext{
${ }^{34}$ R. Kenneth Carty and W. Peter Ward, "The Making of a Canadian Political Citizenship," in National Politics and Community in Canada, eds. R. Kenneth Carty and W. Peter Ward (Vancouver: University of British Columbia Press, 1986), 71-72.

${ }^{35}$ Garth Stevenson, Ex Uno Plures: Federal-Provincial Relations in Canada 1867-1896 (Montreal and Kingston: McGill-Queen's University Press, 1993), 41.

${ }^{36}$ Ibid., 43.
} 
legislative assembly in British North America - through to the present day. To do so, the text meticulously details Canadian franchise law through an exhaustive presentation of enfranchisement progression and regression.

At the factual level, this book is exceptionally useful. It provides much of the necessary statistical and legislative information needed to sustain a detailed study of nineteenth-century Canadian franchise reform. Sadly, for those undertaking such a study, it only barely extends its approach beyond the mere reporting of fact. While every so often the writer attempts to describe why franchise reform occurred when it did and in the way it did, such attempts generally amount to one-sentence declarations that do not provide an incisive argument. For example, the book claims that Prime Minister Macdonald tabled a restrictive franchise act in 1885 because he "had a profound aversion to universal suffrage. ${ }^{37}$ The unsubstantiated brevity of this justification parallels the text's explanation of the Franchise Act of 1898. To the author, the Liberals had designed this act out of fiscal practicality. Because Macdonald's franchise act obliged the federal government to spend excessive amounts of money (primarily in preparing voters' lists), Laurier's Liberals gave jurisdiction over franchise legislation back to the provinces. In doing so, it divested Ottawa of any financial responsibility. ${ }^{38}$ These arguments do not in any substantial way attempt to surpass the previous scholarship on the topic.

Before further disparaging the effort of Elections Canada, one must acknowledge two possible reasons for this somewhat thin analysis. First, $A$ History of the Vote in Canada was designed with a more general readership in mind. Its relatively short 109page length, its journalistic style, and its extensive use of pictures, sidebars, and charts

\footnotetext{
${ }^{37}$ Elections Canada, 49.

${ }^{38}$ Ibid., 52.
} 
clearly reveal this predisposition. It commendably sought to provide Canadians with a ready reference on their vote and its evolution. Since the average reader would tend to lack historiographical background on the topic - and have no desire to wade through the nuanced arguments, the pages of elaborate detail, and the exhaustive documentary support expected by a scholarly audience - the Chief Electoral Officer does not include such heavy fare. His publication instead provides a succinctness that keeps the text flowing and maintains its high readability. While this overall lack of thorough analysis may not please historians interested in Canadian suffrage development and reform, it does reflect the book's overall purpose. Second, the political status of the Chief Electoral Officer may have prevented a candid or speculative explanation of franchise development. As the head of a non-partisan bureau, Jean-Pierre Kingsley could not afford anything that resembled analytical bias - whether Conservative or Liberal - to appear within a book published at his office's behest. Since a lack of analysis represents the most neutral analysis of all, it is perhaps understandable that the author excluded detailed arguments as to nineteenth-century Canadian franchise development. Unfortunately, this ten-year-old factual goldmine still represents the most up-to-date literature on this topic. To find any further information, readers must expand their search criteria to include all studies on the nineteenth-century Canadian franchise, and not just those histories explicitly dedicated to examining its progress.

Scholars have produced a slightly larger body of research on more narrowlyfocused details of the nineteenth-century Canadian franchise. It must be acknowledged here that some of the studies within this historiography do in fact present brief explanations of particular franchise reforms during this period (especially the franchise 
act of 1885). Such accounts, however, do not generally represent the main focus of the studies in question: they instead tend to invoke the franchise as contextual background material or as a means to support a more central argument. Upon assessing this body of literature, the reader perceives three general avenues of investigation. The first of these branches investigates the nineteenth-century franchise in relation to specific groups of Canadians, particularly disenfranchised ones.

One of the earliest of these studies arrived in 1950 with Catherine L. Cleverdon's The Woman Suffrage Movement in Canada. Based on her Columbia University doctoral dissertation, Cleverdon - an American-born historian and former high school teacher traces the struggle for female enfranchisement in Canada from its late nineteenth-century origins until 1940, when Quebec finally eliminated the last vestige of wholesale female disenfranchisement in Canada. As a result, her Whiggish celebration of Canadian suffragists moves far beyond the nineteenth century. A largely descriptive and chronological work, Cleverdon painstakingly enumerates how the provinces each shifted to female suffrage. Her fifth chapter has perhaps the greatest relevance for studies of the federal franchise. Entitled “Ottawa Interlude: Women's Political Rights as a Federal Issue," its fifty pages meticulously traces the path Canadian women followed to receive the federal vote in 1917 and $1918 .{ }^{39}$ While these women successfully completed their journey, Cleverdon argues that suffrage groups during the nineteenth century (largely comprised of elite professionals) took only tentative steps toward enfranchisement because they did not muster the "courage to raise their voices."

\footnotetext{
${ }^{39}$ Catherine L. Cleverdon, The woman suffrage movement in Canada, $2^{\text {nd }}$ ed. (Toronto: University of Toronto Press, 1974), 105-155.

${ }^{40}$ Ibid., 110.
} 
since expanded upon this analysis. For Canadian expatriate and University of Adelaide historian Carol Lee Bacchi, in Liberation Deferred?, the largely white, middle-class suffragists took part in a larger reform movement that viewed family life and female morality as a panacea for the evils of industrialization. Because of their high social status and their belief in a way of life that reinforced the bourgeois values of their husbands, Bacchi argues that the suffragists neither desired to revolutionize sex roles in Canada nor work outside the boundaries of societal norms (where they may have achieved their goals faster). ${ }^{41}$ Despite Bacchi's more controversial analysis, Cleverdon's study still remains the most detailed history of the women's suffrage movement in Canada. As Toronto barrister and solicitor Malcolm Montgomery would remind us, however, women did not represent the sole disenfranchised group in nineteenth-century Canada.

In his article published in Ontario History in 1965, Montgomery focuses on an entirely different group of disenfranchised Canadians: the First Nations. Entitled "The Six Nations Indians and the Macdonald Franchise," the article investigates why certain male First Nations Canadians received the vote in 1885 only for the federal government to withdraw it in 1898. According to Montgomery, partisan benefit played the principal role in this shift. ${ }^{42}$ While the Conservative franchise act of 1885 did not enfranchise all male members of the First Nations, it gave the vote to those who lived off the reservation and owned enough real property to meet the act's franchise qualifications. Montgomery argues that in response to continued Liberal hostility toward First Nations' suffrage, enfranchised First Nations people cast their ballots predominantly for the Conservatives

${ }^{41}$ Carol Lee Bacchi, Liberation Deferred?: The Ideas of the English-Canadian Suffragists, 18771918 (Toronto: University of Toronto Press, 1983), 145-149.

${ }^{42}$ Interestingly, Montgomery does not once cite Norman Ward in his paper. 
by the 1896 federal election. ${ }^{43}$ Yet, the Liberals supposedly dismissed any attempts to "woo the Indian electorate." contends that the Liberal party returned the federal franchise to the provinces with full knowledge that they, the provinces, had not yet enfranchised Canadians of First Nations descent. ${ }^{45}$ Montgomery concludes that the First Nations lost the vote because, in the eyes of the Liberal government in Ottawa, they did not cast their ballots for the right candidates. As a result of this Liberal decision, the First Nations had to wait until 1960 to federally exercise the vote again. ${ }^{46}$ As for Montgomery's argument concerning the Franchise Act of 1898 - that the Liberals designed it to silence oppositional First Nations voters - such an explanation can by no means fully account for the act's inception. First Nations voters represented much too small a percentage of the electorate to justify a drastic Liberal change of federal franchise law. That said, this article does at least point to one of the multiple rationalizations that may help clarify why the federal Liberals chose to table the Act in the first place. Almost four decades later, University of British Columbia social historian Veronica Strong-Boag adopts a comparable approach to the franchise act of 1885 .

Veronica Strong-Boag's chapter entitled “"The Citizenship Debates': The 1885 Franchise Act" in a book of essays about Canadian citizenship provides one of the most recent examples of such studies investigating disenfranchised groups. The first two sections of her chapter briefly set the stage and explain who in Canada had been

\footnotetext{
${ }^{43}$ Malcolm Montgomery, "The Six Nations Indians and the Macdonald Franchise," Ontario History 57.1 (1965), 16-18; 23.

44 Ibid., 22.

45 Ibid., 22-23.

${ }^{46}$ Ibid., 25.
} 
disenfranchised prior to 1885 . The third provides a very quick snapshot of which groups disenfranchised before 1885 their reactions to their disenfranchisement. The core of the paper, however, concentrates on the Conservative franchise act itself and, more specifically, how it treated three groups of these disenfranchised Canadians: women, the First Nations, and Chinese immigrants. Strong-Boag introduces this section with a short page-and-a-half contextual summary of the act and the reasons for its implementation. In writing it, however, she principally relies on Norman Ward's work mentioned earlier in this paper. ${ }^{47}$ It therefore provides little new illumination into why this particular reform occurred.

Strong-Boag's subsequent investigation of women's, First Nations', and Chinese citizenship is much more useful. Drawing upon 1885's House of Commons Debates, she enumerates the Parliamentary arguments from both sides of the Legislature as to why these three groups should or should not receive the vote. According to the Debates, both Liberal and Conservative Members of Parliament supported this enfranchisement (especially for women of European origin). But, as Strong-Boag relates, these members were in the minority. The majority, reflecting nineteenth-century racial and gender norms, had supposedly already designated "women, Natives, and Asians...as properly subordinated. ${ }^{48}$ She concludes that this bias inherent within the white ruling elite ensured these disenfranchised groups would remain predominantly disenfranchised despite franchise reform in $1885 .^{49}$ Admittedly, Strong-Boag's argument based on racial and gender prejudice does not exactly break any new ground within this branch of

\footnotetext{
${ }^{47}$ Veronica Strong-Boag, “'The Citizenship Debates,"' in Contesting Canadian Citizenship, ed. Robert Adamski, Dorothy E. Chunn, and Robert Menzies (Peterborough: Broadview Press, 2002), 75-76.

${ }^{48}$ Ibid., 90.

${ }^{49}$ Ibid., $90-91$.
} 
franchise studies. One can find notions of such bias within the earlier works of

Cleverdon and Montgomery as well. Still, Strong-Boag's essay provides perhaps both the best summation of minority disenfranchisement between 1885 and 1898 , and the best summation of this branch of franchise studies in general.

The second thrust of nineteenth-century franchise studies revolves around the federal elections themselves and how individuals circumvented franchise or electoral law. In "Sinners and Publicans: Sir John A. Macdonald's Trial under the Controverted Elections Act, 1874," Montreal lawyer Thomas Brady employs microhistory to approach this broad theme. After John A. Macdonald won the federal seat for Kingston, Ontario in the January 1874 election by a mere 37 votes, Kingston Liberals immediately petitioned the government to void the election "on the grounds of bribery and corrupt practices." Using Macdonald's subsequent controverted elections trial as a case study, ${ }^{51}$ Brady argues that the transformation of such trials from a partisan political process to a more impartial public inquiry took part in a broader electoral reform that changed electioneering in Canada. ${ }^{52}$ While the trial cleared Macdonald of any wrongdoing because of the ambiguous and inconclusive evidence levelled against him, it did reveal that widespread electoral misbehaviour - from 'treating' voters to alcoholic beverages to outright bribery - on the part of Macdonald's campaigners may have helped Macdonald

${ }^{50}$ Thomas Brady, "Sinners and Publicans: Sir John A. Macdonald's Trial under the Controverted Elections Act, 1874," Ontario History 76.1 (1984), 69.

${ }^{51}$ As one of the checks and balances to nineteenth-century Canadian elections, the losing candidate could challenge an election result if he felt the contest unfairly contested. A controverted elections trial would subsequently investigate the allegation. Once he heard the case, the judge hearing the trial had the power to let the election result stand, call a by-election, or even bring charges against the candidates.

${ }^{52}$ Ibid., $65 ; 80$. 
win the election. ${ }^{53}$ Although Brady's study has, at best, a tenuous connection to nineteenth-century enfranchisement, his discussion of illegal electoral practices produces an interesting implication: that such dishonesty was in all likelihood a nationallypervasive phenomenon in nineteenth-century Canada. If this presumption is correct, electoral corruption may have also extended to and infiltrated local decisions as to who could (or could not) vote during a given election.

In the same volume of Ontario History, James A. Eadie's “The Federal Election in Lennox Riding and Its Aftermath, 1882-83: A Glimpse of Victorian Political Morality" broadens Brady's inference concerning federal electoral corruption. Adopting the same case study approach, Eadie - a retired history department head at Napanee District Secondary School - also chooses to focus on one of John A. Macdonald's electoral campaigns. Macdonald ran for the Lennox seat (centred on Napanee, Ontario) during the 1882 federal election. ${ }^{54}$ As in 1874, the Liberals alleged that Macdonald and his campaigners bribed the electorate. Once again, they challenged Macdonald's victory under the Controverted Elections Act. ${ }^{55}$ Eadie uses this controverted election and its aftermath as a window into the political culture surrounding nineteenth-century electoral corruption. He argues that, in contrast to the supposedly stern morality maintained by the typical Victorian Canadian in private life, Canadians from all ranks of society during this period "had become inured to, and tolerant of," the largely widespread political

\footnotetext{
${ }^{53}$ Ibid., 75.

${ }^{54}$ James A. Eadie, "The Federal Election in Lennox Riding and Its Aftermath, 1882-83: A Glimpse of Victorian Political Morality," Ontario History 76.4 (1984), 353-354. Lennox was also the former political domain of Liberal Member of Parliament and Cabinet Minister Sir Richard Cartwright.

${ }^{55}$ Ibid., 353. The Controverted Elections Act created the infrastructure necessary for individuals to challenge the outcomes of elections. It also provided for establishment of the aforementioned
} controverted elections trials. 
misbehaviour that occurred in the public sphere. ${ }^{56}$ To substantiate his claim, Eadie, using politicians' personal papers and the local press, suggests that Macdonald's controverted elections trial did not cause any great reaction, negative or otherwise, amongst Lennox's clergy or general population. ${ }^{57}$ While Eadie perhaps overgeneralizes in allowing primarily Protestant English Canadians from Lennox to speak for the entire nation, including Catholic French Canadians from Quebec, his argument does support and advance the implications of Brady's article. If electoral corruption was as systematic and as accepted as Eadie suggests, underhanded local alterations to voters' lists seem probable as well. The last article within this second branch of franchise studies provides a well-argued affirmation to this assumption.

In their 1986 article entitled "The Franchise, Personators, and Dead Men: An Inquiry into the Voters' Lists and the Election of 1891," Canadian historians Ben Forster, Malcolm Davidson, and R. Craig Brown adopt a somewhat different approach to nineteenth-century elections than that of Brady and Eadie. Instead of focusing on controverted elections trials, the authors investigate electoral discrepancy by means of the 1891 federal voters' lists. More specifically, they wish to understand why some legal voters at the time of the 1891 federal election were denied the vote and (more importantly to them) why so many extra voters across Canada submitted ballots. ${ }^{58}$ Before they attempt to clarify these inconsistencies, Forster, Davidson, and Brown contextualize

${ }^{56}$ Ibid., 369.

${ }^{57}$ Ibid., 365-368.

${ }^{58}$ Ben Forster, Malcolm Davidson, and R. Craig Brown, "The Franchise, Personators, and Dead Men: An Inquiry into the Voters' Lists and the Election of 1891," Canadian Historical Review 67.1 (March 1986), 17-19. 
enfranchisement at the time of the election through a brief investigation of 1885 's franchise act.

Based on their readings of the House of Commons Debates, these three authors contend that several factors combined to explain why the Conservatives passed the franchise act of 1885. These reasons included the now well-worn Conservative desires to uphold their ideological belief in a property-qualified suffrage, to break the provincial Liberal stranglehold over enfranchisement, and to ensure anticipated supporters would receive the vote. ${ }^{59}$ To this list, Forster, Davidson, and Brown add newer explanations of the act as well. For example, they claim that the Tories endorsed the franchise act in part to rationalize federal franchise law. ${ }^{60}$ In placing the federal franchise solely under the federal banner, the Dominion would require only one piece of franchise legislation for federal elections, as opposed to six different ones. Prior to this article, the more politically crass explanations of expediency and partisan benefit had generally dominated the nineteenth-century franchise analysis. For possibly the first time within the historiography, these authors place franchise reform within the sphere of good governance. Just as innovative, they employ the concept of political culture with regard to nineteenth-century enfranchisement. By means of this viewpoint, Forster, Davidson, and Brown assert that the franchise act of 1885 also took part in a Tory attempt to foster a conservative national political culture that revolved around the party and its ideology. ${ }^{61}$ Despite the inclusion of such novel explanations, the reader cannot help but notice the narrow, party-centric focus of this investigation. While it speaks about political culture,
${ }^{59}$ Ibid., $19-20$.
${ }^{60}$ Ibid., 19.
${ }^{61}$ Ibid. 
it does not mention the ways that Canadians outside of Parliament may have aided in shaping this culture. Indeed, it does not mention the broader Canadian public with regard to franchise reform whatsoever. This omission impedes the article's ability to persuasively account for the act and its contents. On the other hand, they provide a much more convincing description as to how these contents translated into reality at election time.

To Forster, Davidson, and Brown, the franchise act's content, at its most fundamental level, represent mere words on a page. It took the work of individual bureaucrats - the revising officers - to put the act into practice. ${ }^{62}$ In their analysis, the authors admit that some revising officers worked explicitly to develop voters' lists that would benefit a particular political party. The authors do not believe, however, that the partisan actions of a few biased appointees could have inflated the federal voters' lists to the extent encountered. ${ }^{63}$ They argue instead that the "Byzantine" complexity of the franchise act itself, coupled with Ottawa's financial inability to create new voters' lists to account for voter migration, led to the countless electoral discrepancies encountered on election day. ${ }^{64}$ Indeed, the authors argue that Ontario voters' lists contained almost 30,000 more names than adult men in Ontario largely because the electoral officers had such difficulty coping with the demands of the act. ${ }^{65}$ The article therefore provides an interesting conclusion that expands upon Brady's and Eadie's line of inquiry. While corrupt bureaucrats did have opportunities to alter enfranchisement at the local level, the

${ }^{62}$ Ibid., 22-23.

${ }^{63} \mathrm{lbid} ., 25-27$.

${ }^{64}$ Ibid., 38. This complexity ranged from a bizarre revising formula that made it easier to get names on voters' lists than to have them removed, to the possibility that, because of population movement, one man could have his name on multiple lists. See: Forster, Davidson, and Brown, 24-26; 30.

${ }^{65}$ Ibid., 58; 
convoluted nature of the franchise legislation supposedly ensured that discrepancies concerning suffrage would occur anyway. Although the franchise act stipulated who could or could not vote, this second branch of franchise studies reminds the reader to move beyond the written act: he or she must delve into the messy world of Canadian electoral politics to fully understand nineteenth-century enfranchisement.

The last area of these more narrowly-focused franchise studies is also the least densely populated. This offshoot seeks to explain why specific nineteenth-century Canadian politicians pursued particular franchise reforms at all. In his 1894 Memoirs of the Right Honourable Sir John A. Macdonald, Macdonald's private secretary, Sir Joseph Pope, devotes three pages "to say a word on a subject which he [Macdonald] considered of great importance, namely the Franchise Act of 1885."66 Employing both Macdonald's correspondence and his own close working relationship with Macdonald to support his arguments, Pope cites that "The main principles underlying Sir John Macdonald's Franchise Act are (1) uniformity of the suffrage, and (2) the recognition of a property qualification as determining the right to vote. ${ }^{.67}$ According to Pope, Macdonald apparently tabled new franchise law as a way to both assimilate the political conditions in the various provinces and (in true conservative fashion) assure the ascendency of property-owners within the country. ${ }^{68}$ Unfortunately, Pope does not take his analysis of Macdonald's ideological reasons for new franchise legislation any further, thus limiting its explicative power. Still, his contentions with respect to this particular franchise reform fit nicely with those forwarded by W. L. Morton.

\footnotetext{
${ }^{66}$ Sir Joseph Pope, Memoirs of the Right Honourable Sir John A. Macdonald, vol. II (Ottawa: J. Durie \& Son, 1894), 245.

${ }^{67} \mathrm{Ibid} ., 247$.

${ }^{68}$ Ibid.
} 
To find a scholarly embodiment of this area of nineteenth-century federal franchise scholarship, one must leap forward almost one hundred years to 1982. In that year, Michigan State University historian Gordon Stewart published the article "John A. Macdonald's Greatest Triumph". Adopting a completely different argument than Sir Joseph Pope, Stewart uses the franchise act of 1885 to springboard into a discussion on how Prime Minister Macdonald relied upon and exploited patronage when in power. According to Stewart's argument (in the first section of his article), Macdonald saw patronage as the overwhelming reason for suffrage reform. ${ }^{69}$

New franchise legislation supposedly provided Macdonald with power over patronage in two ways. First, tailoring enfranchisement to encapsulate traditionally Conservative voters while excluding traditionally Liberal voters provided better odds for re-election. Remaining in office meant continued use of the government purse to reward loyal party members. ${ }^{70}$ Second, this legislation placed governance over the franchise in the hands of the federal government, including the power over voters' lists and revising officer appointments. Macdonald thus added the job of revising officer to his already long list of patronage positions. This patronage post, of course, was cleverly connected to the goal of re-election: Conservatives manning the polls could (and sometimes did, as illustrated by Forster, Davidson, and Brown) interpret the franchise act in ways that ensured known Conservatives cast their ballots, and prevented known Liberals from

\footnotetext{
${ }^{69}$ Gordon Stewart, "John A. Macdonald's Greatest Triumph," Historical Review 63.1 (March 1982), 3-4.

${ }^{70}$ Ibid., 4.
} 
submitting theirs. ${ }^{71}$ Stewart's argument therefore builds nicely on the contentions forwarded by Norman Ward (and to a much lesser extent, W. L. Morton). The formation, dispersal, and exploitation of new patronage positions certainly reinforce motivations of partisan benefit. Since Stewart does not take any other potential reasons into account, however, his article cannot adequately explain the franchise act of 1885 . Then again, such an explanation was not his primary goal. After Stewart's line of examination, investigations into the nineteenth-century Canadian franchise come to an end. To retrieve additional information outside of these three categories of study, one must leave the Canadian federal sphere altogether and enter the realm of the Canadian provincial franchise.

So far, only one investigation of a nineteenth-century Canadian provincial franchise has been undertaken. Roman Wasyl Franko performed this examination for his unpublished Queen's University doctoral dissertation in political science completed in 1992. Entitled "Toward a Liberal Democracy in Ontario: The Franchise and PolicyMaking 1868-1888," it traces the development of the Ontario franchise from a relatively strict property-based franchise to universal manhood suffrage. While it may at first seem otherwise, much of Franko's content on the Ontario provincial franchise has direct bearing on the study of the Canadian federal franchise. ${ }^{72}$ Since governance over the

${ }^{71}$ Ibid., 6-8. Journalist Jeffrey Simpson echoes this argument in his excellent text on the politics of patronage in Canada entitled Spoils of Power. See: Jeffrey Simpson, Spoils of Power (Toronto: Collins, 1988), 201-202.

${ }^{72}$ In her biography of Ontario premier Sir Oliver Mowat, Margaret Evans briefly mentions the federal franchise in light of that of Ontario. Instead of describing the effect (if any) Mowat may have had on Macdonald's choice to reform the Dominion franchise in 1885, she merely writes that "When the House of Commons opened in January 1885, Macdonald announced that he would introduce a uniform franchise in federal elections to replace the different provincial qualifications. This convinced Mowat that the time had come for a new law in Ontario, which might steal some of the acclaim from the prime minister." If anything, Evans seems to suggest that Ontarians viewed Macdonald's uniform franchise favourably. This 
federal franchise rested in provincial hands between 1867 and 1885, the dissertation (for most of its span) technically discusses the federal franchise as well. As a preface to his argument concerning the Ontario franchise, Franko rightly affirms that no one had yet "provide[d] a comprehensive description, let alone explanation, of franchise extensions in post-Confederation Canada." ${ }^{.73}$ In his attempt to offer such a comprehensive explanation that addresses previous research, Franko forwards a highly theoretical three-pronged hypothesis concerning policy innovation.

According to Franko's premise, franchise reforms - as well as all other policy innovations for that matter - result from the following factors: 1) the grievances of new social movements that have arisen from socio-economic change; 2) the ideological principles designed and espoused to legitimate particular socio-political innovations; and, 3) the political beliefs and partisan desires of opposition party politicians. ${ }^{74}$ Throughout his dissertation, Franko attempts to fit Ontario franchise development into this universalist theory. In comparison to other analyses of Canadian franchise reform, his is quite thorough: it accounts for extra-governmental opinion, ideological motivations, the legitimization of power, and the partisan desires of one half of the Legislative Assembly. Yet, Franko's tripartite theory has one glaring limitation. While it acknowledges partisan benefit on the part of the Opposition party, it does not allocate the same motivations to the party in power - the very party that would have enacted any franchise legislation in the first place. Considering the fact that Canadian historians and political scientists have

may suggest one reason why Macdonald advanced it. See: A. Margaret Evans, Sir Oliver Mowat (Toronto: University of Toronto Press, 1992), 209.

${ }_{73}$ Roman Wasyl Franko, "Toward a Liberal Democracy in Ontario: The Franchise and PolicyMaking 1868-1888," Ph.D. diss. (Queen's University, 1992), 8.

${ }^{74}$ Ibid., 10. 
rather exhaustively detailed how franchise reforms reflected the government party's desire to maintain its dominance, Franko's omission of this factor leaves his analysis incomplete. Despite the fact that this significant problem limits his theory's applicability, Franko does provide detailed historical evidence as to why the Ontario government progressively lowered franchise qualifications right through to 1888. Beyond Franko's provincial franchise study, no other substantial body of Canadian franchise literature exists. The gap in the historiography surrounding the Canadian franchise remains unpatched.

Sixty-five years have now passed since W. L. Morton's trailblazing work on nineteenth-century Canadian federal franchise reform. Despite his best efforts to highlight a principle so important to the freedoms enjoyed by all Canadians, few scholars have chosen to follow the path he pioneered. In almost seven decades, five others wrote explicitly on this particular topic (if one counts the four or so pages written by Kenneth Carty, Peter Ward, and Garth Stevenson). Of these five, only one - Norman Ward attempted any sort of novel critical analysis. If one expands the search criteria to encompass everything written on the nineteenth-century Canadian franchise, one fares somewhat better. Still, such a query yields about a dozen results - a paltry number at best. Taking all of these texts into account, not one of them satisfactorily explains why the nineteenth-century federal franchise evolved in the way it did. They either overlook key explanatory factors, leave questions unanswered, repeat older incomplete investigations, or present arguments too narrowly centred on one piece of legislation. That said, the existing literature offers no shortage of theories as to why franchise reform took place. These hypotheses range from more mundane explanations such as political 
ideology and partisan expediency, to arguments about public pressure and racial prejudice. With all of these theories to draw upon, one should remember the words of Harvard historian Alexander Keyssar. At the end of his 2000 award-winning history of American franchise entitled The Right to Vote, he offers some sage advice for those interested in studying franchise development. Considering the franchise of each state underwent its own process "of both expansion and contraction, of inclusion and exclusion, of shifts in direction and momentum at different places and at different times", Keyssar warns his readers "that the search for any single-factor explanation...is misguided." ${ }^{75}$ Methodologically, the following study of the nineteenth-century Dominion franchise takes Keyssar's counsel as its starting point.

As the preceding discussion of the relevant body of work has illustrated, scholars of the nineteenth-century Canadian franchise have moved progressively away from the single-factor explanations of legislative evolution that Keyssar criticizes. Consequently, their explanations have become more complex and their research more thorough. Still, as highlighted here, no one manuscript or article has completely accounted for the spectrum of factors that may have had a role in stimulating franchise development. This study will attempt such a multivarious account. Taking into consideration potential influences such as ideology, expediency, partisanship, good governance, and popular pressure, it will determine the role each of these played in promoting new federal franchise legislation. Of course, these influences do not all carry the same weight. Embracing the general stance of W. L. Morton's pioneering work in particular, this investigation will hold

\footnotetext{
${ }^{75}$ Alexander Keyssar, The Right to Vote (New York: Basic Books, 2000), xx; 195. Much like the situation in Canada at Confederation, each individual state governed its own federal franchise legislation. In 2000, Keyssar's text won the American Historical Association's award for best book in American history. It was also a finalist for the Pulitzer Prize that same year.
} 
political ideology and partisan politics of the legislators themselves as the two principal motivating factors for nineteenth-century Dominion franchise development. Differing rather markedly from Morton, however, arguments here will take a more theoretical turn. They will do so through their reliance on the concept of 'state formation' - "the processes by which states emerge". ${ }^{76}$

Although sociologists first coined the term in the 1960 s, the pedigree of state formation reaches as far back as the nineteenth and early-twentieth century literature on the state itself. In their attempts to explain the state's role in society and how it functions, social theorists such as Karl Marx, Emile Durkheim, Alexis de Tocqueville, and Max Weber all contributed crucial ideas that would eventually give rise to the present concept. While Marx advanced the notion that the state represents an organizing and subjugating force that acts in the interest of a minority (in his view, an economic minority, the bourgeoisie), ${ }^{77}$ Durkheim later argued that the state acts as an "organ of social thought" and "above all,...the organ of moral discipline". ${ }^{78}$ These two writers therefore implicitly agreed with de Tocqueville's earlier assessment that the state operates in such a way that it can shape not only political aspects of life but seemingly non-political ones as well, such as social relationships. ${ }^{79}$ Yet, Marx, Durkheim, and de Tocqueville only defined

76 "state," A Dictionary of Sociology, eds. John Scott and Gordon Marshall (New York and Oxford: Oxford University Press, 2009), 728.

${ }^{77}$ Throughout their careers, both Karl Marx and his literary partner Friedrich Engels wrote substantially on the role of the state within society. For references to this belief that the state organizes society to realize bourgeois interests, refer to The German Ideology and Critique of the Gotha Program in particular. See: Karl Marx and Friedrich Engels, The Marx-Engels Reader, ed. Robert C. Tucker, $2^{\text {nd }}$ edition (New York and London: W. W. Norton, 1978), 186-188 and 537-539.

${ }^{78}$ Emile Durkheim, Professional Ethics and Civic Morals, trans. Cornelia Brookfield (London: Routledge \& Kegan Paul, 1957), 79 and 72; Herrick Chapman, "State and Society," Encyclopedia of Social History, ed. Peter N. Stearns (New York and London: Garland, 1994), 719.

${ }^{79}$ For de Tocqueville, state control of everyday life represents the "sort of despotism democratic nations have to fear". Sincede Tocqueville believed that what sociologists now call state formation stifles 
what the state does; they never ventured to clarify what comprises it. As Herrick

Chapman explains in the Encyclopedia of Social History, Weber subsequently attempted

to fill this theoretical void when he referred to the state "as a cultural, organizational, and legal entity - as authority, bureaucracy, and rules - that evolved not just in response to societal pressures but also in accord with an internal developmental logic." ${ }^{80}$ For Weber, the state therefore encompasses much more than merely 'government'. This belief will represent one of the cornerstones for state formation theory in the decades to come. ${ }^{81}$

As a result of such different approaches to defining the state, two contending visions of state formation have since arisen. Canadian historians Allan Greer and Ian Radforth concisely outline these positions in Colonial Leviathan, their edited work on state formation in mid-nineteenth-century Canada. ${ }^{82}$ On the one hand, the Marxian/Durkheimian/Tocquevillain approach has spawned the study of state formation as a "cultural phenomenon". ${ }^{83}$ According to academics who espouse this idea in particular, such as sociologists Philip Corrigan and Derek Sayer (to name but two), the state attempts to employ the power it has amassed to transform a given culture so that it

democracy, it would either lead to "freer institutions" (because the people tire of state repression) or the state "soon fall[ing] back at the feet of a single master." See: Alexis de Tocqueville, Democracy in America, ed. J. P. Mayer, trans. George Lawrence (New York: Harper and Row, 1988), 690-695. See also: Chapman in Encyclopedia of Social History, 719.

${ }^{80}$ For the quotation, see: Chapman in Encyclopedia of Social History, 719 . Weber's thoughts concerning the state extend through a series of different texts. In the brochure entitled "The Profession and Vocation of Politics", Weber himself defined the state as an "institutional association of rule". See: Max Weber, Political Writings, ed. Peter Lassman and Ronald Speirs (Cambridge: Cambridge University Press, 1994), 316.

${ }^{81}$ Allan Greer and Ian Radforth maintain this view in Colonial Leviathan, their own text on state formation. Colonial Leviathan was published in 1992. See: Allan Greer and Ian Radforth, eds. Colonial Leviathan: State Formation in Mid-Nineteenth-Century Canada (Toronto: University of Toronto Press, 1992), 9.

${ }^{82}$ See: Ibid., 9-11.

${ }^{83}$ Ibid., 10. 
may create a cultural acceptance of itself and its goals. ${ }^{84}$ Drawing heavily upon Italian Marxist Antonio Gramsci's notion of hegemony and French philosopher Michel

Foucault's discussion of governmentality, state formation represents the state's increasing penetration of and diffusion within the given culture to produce the societal vision of those who wield power. ${ }^{85}$ Hence, Corrigan and Sayer have argued that state formation reflects nothing less than a "cultural revolution". ${ }^{86}$ For those who have adopted the Marxian/Durkheimian/Tocquevillain approach, however, the state has generally remained a somewhat ethereal entity. While such scholars broadly mention "institutions of the state", many tend not to go into great detail as to the particular roles specific agencies play. ${ }^{87}$ Here, on the other hand, is where the Weberian approach tends to recommend

${ }^{84}$ Philip Corrigan and Derek Sayer, The Great Arch (Oxford: Basil Blackwell, 1985), 2-3.
${ }^{85}$ While Karl Marx argued that the state represents an instrument of an economic minority, Antonio Gramsci believed that the state reproduced cultural and moral aspects of life instead of merely economic ones. To explain this process, Gramsci developed his concept of hegemony. By means of cultural and moral consensus and coercion, the interests of the ruling class (as the minority that controls the reigns of state) slowly become the universal interests of society in general. Once the whole of society embraces these particular interests, hegemony is achieved. See: Antonio Gramsci, Prison Notebooks, ed. and trans. Quintin Hoare and Geoffrey Nowell Smith (New York: International Publishers, 1971), 12-13. With governmentality, on the other hand, Michel Foucault discards any notion of class struggle and centres his focus purely on how state's exercises power for the purpose of social discipline. As Simon Gunn puts it in his interpretation of Foucault, governmentality concerns the state's "conduct of conduct". Through "the formation of a whole series of specific governmental apparatuses" - in other words, bureaucratic institutions - the state collects knowledge concerning its "target population". Through such knowledge, it can better guide the behaviours of those who comprise a given society. Yet, one must also understand that coercion does not necessarily result. Instead, individuals may accept and internalize these behaviours and reproduce them willingly. The governmentalized state comes to fashion individuals who govern themselves. Through this ongoing process, the state forms itself and its disciplinary proficiency increases. See: Graham Burchell, Colin Gordon, and Peter Miller, eds., The Foucault Effect: Studies in Governmentality with two lectures by and an interview with Michel Foucault (Chicago: University of Chicago Press, 1991), 102-103. See also: Simon Gunn, History and Cultural Theory (Harlow: Pearson, 2006), 91. For a more thorough discussion of discipline and its objectives, see also: Michel Foucault, Discipline and Punish, trans. Alan Sheridan (New York: Vintage Books, 1995), 135-169.

${ }_{87}^{86}$ Corrigan and Sayer, 2

${ }^{87}$ For example, see: Ibid., 3-4. The Politics of Population: State Formation, Statistics, and the Census of Canada, 1840-1875, by Carleton University sociologist Bruce Curtis, represents a growing exception to this rule. While he explicitly draws upon Corrigan's and Sayer's belief that state formation reflects a cultural revolution, Curtis centres his arguments on one institution in particular: Canada's federal census. More and more, scholars have begun to ground their cultural discussions of state formation in the specific institutions and agencies that comprise the state. For his reference to Corrigan and Sayer, see: 
itself. Championed principally by Harvard sociologist Theda Skocpol, this view of state formation focuses squarely on the bureaucratic institutions that comprise the state to determine how they have developed their capacities to administrate, regulate, and coerce. ${ }^{88}$ In his own essay in Greer's and Radforth's volume, Allan Greer thus focuses on the emergence of the police force in nineteenth-century Canada. ${ }^{89}$ To those who follow Weber and Skocpol, state formation consequently consists of this institutional development itself. Greer and Radforth, in the end, refuse to "make a case for one or the other of these conceptions of state formation". ${ }^{90}$ The following study will be more discerning.

With respect to the connection between state formation and franchise development in the Canadian context, this research argues that the Marxian/Durkheimian/Tocquevillian approach holds much promise. Since Dominion franchise reform did not particularly result from any bureaucratic development, Weber's and Skocpol's view of state formation does not readily seem to apply. And while Skocpol does briefly discuss the part political leadership plays in state formation, she ascribes it a more marginal role: in its struggle to maintain power, it creates the environment through which state formation may occur. ${ }^{91}$ As such, Skocpol seems to view political leaders as potential catalysts to state formation but not those who attempt

Bruce Curtis, The Politics of Population: State Formation, Statistics, and the Census of Canada, 18401875 (Toronto: University of Toronto Press, 2001), 37.

${ }^{88}$ Theda Skocpol, State and Social Revolutions (Cambridge and New York: Cambridge University Press, 1979), 161-162; 173.

${ }^{89}$ See: Allan Greer, "The Birth of the Police in Canada," in Colonial Leviathan, 17-49.

${ }^{90}$ Greer and Radforth, 11.

${ }^{91}$ Skocpol, 168. 
to oversee state formation themselves. This inquiry will argue that this was not the case when it came to nineteenth-century federal franchise reform in Canada.

Instead, when this analysis draws upon the idea of state formation as a cultural revolution, it will hold a very specific idea of culture in mind. While scholars such as Durkheim, Corrigan, and Sayer mention culture only very broadly in their analyses, this research will zero in upon the type of culture that arguably played the largest part in federal franchise development: political culture. ${ }^{92}$ Indeed, it will argue that the development of the nineteenth-century Dominion franchise took place in large part because state legislators wished to revolutionize, regulate, and normalize the dominant political ideologies upheld within the country. By means of franchise reform, these legislators could alter the shape and composition of the electorate. While they could not necessarily enfranchise or disenfranchise groups of Canadians solely because of their ideological proclivities, statesmen - the term this thesis will employ to describe those state actors who attempted to carry out the larger project of state formation - could

\footnotetext{
${ }^{92}$ Like state formation, political culture has also received various definitions by those who study it. For instance, the Blackwell Dictionary of Sociology defines political culture as the "accumulated store of the symbols, beliefs, attitudes, norms, and other cultural products that shape and govern political life in a society." Since the entry's author also links the concept of political culture with Gramsci's concept of hegemony, this definition of political culture seems to tie in nicely with the study of state formation as well. In the Canadian context, University of Toronto political scientist Nelson Wiseman has very recently described political culture as "the way of life of a political community or polity." To Michael Thompson, Richard Ellis, and Aaron Wildavsky, in their groundbreaking work on political culture, such descriptions would be too vague. While they also view "political culture as patterns or orientation toward political action or objects", they believe that if one does not expand upon that definition one "sidesteps the question of what is to count as political." Indeed, these three authors suggest that "[s]ome insist that all action is political", from shopping to child-rearing, because every action in some fashion participates within domain of power relations. Thompson, Ellis, and Wildavsky therefore recommend to those who wish to define political culture that they should clearly demarcate the boundaries between the political and the nonpolitical. With regard to this study's use of political culture, the political solely refers to the affairs and governance of the state. See: "political culture" in Allan G. Johnson, Blackwell Dictionary of Sociology, $2^{\text {nd }}$ ed., (Malden, Mass.: Blackwell, 2000), 227; Nelson Wiseman, In Search of Canadian Political Culture (Vancouver: University of British Columbia Press, 2007); Michael Thompson, Richard Ellis, and Aaron Wildavsky, Cultural Theory (Boulder, San Francisco, and Oxford: Westview Press, 1990), 216-217.
} 
exercise their power more generally to institute legislation that adhered to a particular ideology or encompassed economic, social, or racial groups believed to uphold that ideology. ${ }^{93}$ As such, conservative or liberal statesmen, through new franchise legislation, could attempt to ensure the dominance of conservative or liberal political ideology within the nation's political culture. With a new political culture legitimated through the electorate, these statesmen may have consequently hoped that the state would progressively form itself along those lines. Because of its emphasis on state formation, the following study will tend to adopt a predominantly, but not exclusively, top-down approach to its arguments and explanations. ${ }^{94}$

To support these arguments, this investigation will employ a wide range of both official and popular sources, including the Confederation debates in central British North America, the debates of the House of Commons, both Conservative and Liberal parliamentarians' correspondence, political party literature, and the proceedings of nineteenth-century occupational associations (such as the Canadian Labor Congress). In its effort to gauge popular opinion concerning franchise reform, this study will also rely upon eighteen contemporary newspapers from across the country. From west to east, these newspapers are: the Victoria Daily Colonist, The Victoria Daily Times, The Brandon Mail, the Manitoba Daily Free Press, the Palladium of Labor, the Toronto Globe, the Toronto Evening News, the Toronto Evening Telegram, The Toronto World,

\footnotetext{
${ }^{93}$ As such, this thesis will not employ the term 'statesman' in the more traditional brokerage sense (i.e. a political leader who rises above narrow, parochial interests to shape national policy).

${ }^{94}$ To make a full account of nineteenth-century Dominion franchise reform, this study of course cannot solely focus on high politics, elected officials, and legislative decisions. If it did, it would most likely overlook any ways that extra-governmental opinion affected the direction of franchise development. That said, my approach will generally contrast with other Canadian political histories that zero in upon the public sphere and the authority of public opinion, such as The Capacity to Judge by Queen's University historian Jeffrey McNairn. See: Jeffrey L. McNairn, The Capacity to Judge (Toronto: University of Toronto Press, 2000), 3-19.
} 
The Montreal Daily Star, La Presse, Le Courrier du Canada, The Summerside Journal and Western Pioneer, the Charlottetown Daily Examiner, Charlottetown Daily Patriot, the Acadian Recorder, and the Halifax Chronicle (including its direct predecessor, the Novascotian). In selecting these particular examples, an attempt has been made to conform as closely as possible to a set of predetermined, balanced criteria based upon a newspaper's location, political affiliation, and press run. With each province possessing its own franchise, it is understandable that opinions concerning the franchise varied considerably by location or region. While this variance occurred most obviously at the provincial level, attitudes toward the franchise may have also tended to differ whether expressed in an urban or rural environment, or in English or French Canada. Through these eighteen newspapers, an attempt will be made to capture as many of these potential regional outlooks as possible. Due to the temporal constraints of Master's level research, this thesis does not move beyond this sampling. Of course, the political allegiance of a given newspaper had a profound effect on the opinion offered within. In other words, a Conservative or Liberal newspaper would generally tout the party line as expressed in the House of Commons no matter its geographical situation. For this reason, this research has incorporated as many independent newspapers (those newspapers that received no financial support from Canada's political parties and refused to act as mouthpieces for those parties) as possible to measure opinions of Canadians outside of political party circles. With respect to those areas that did not possess an independent press - such as Victoria, British Columbia and Charlottetown, Prince Edward Island for example - this 
research will consult both the Conservative and Liberal organs to strike a balance of opinion. ${ }^{95}$

Out of the three aforementioned criteria, however, the length of a given newspaper's press run is perhaps the most limiting. When Parliament tabled franchise legislation, one could look to just about any newspaper in print at the time to find some sort of opinion about the new bill. To determine whether press attitudes toward the franchise evolved in any way, however, one must instead read those journals that managed to stay in business between franchise acts. Regrettably, in the cutthroat world of the late-nineteenth-century Canadian press, very few survived from 1867 through to 1898. Moreover, these rare examples - such as the Toronto Globe - tended to survive because of their status as dogged party organs. ${ }^{96}$ Employing only those newspapers that reported on all three nineteenth-century Dominion franchise acts does not therefore represent a viable option. Consequently, this research will endeavour to select journals whose press run spanned at least two pieces of franchise legislation. All of the eighteen newspapers do so with the notable exception of two: the Palladium of Labor and the Brandon Mail.

Admittedly, Hamilton's Palladium of Labor only existed for approximately four years in the mid $1880 \mathrm{~s}$. As a result, it does not provide the same sort of comprehensive

\footnotetext{
${ }^{95}$ The appendix to University of Toronto historian Paul Rutherford's monograph on latenineteenth-century Canadian daily press lists the political affiliations (or lack thereof) of Canada's leading newspapers published between the years of 1870 and 1900. See: Paul Rutherford, $A$ Victorian Authority (Toronto: University of Toronto Press, 1982), 235-240. While Rutherford also discusses the patronage opportunities available to those newspaper editors willing to speak for a particular political party, John Abbott College historian Minko Sotiron's text on the commercialization of Canadian daily newspapers perhaps provides the best source on the topic. See in particular: Minko Sotiron, From Politics to Profit (Montreal and Kingston: McGill-Queen's University Press, 1997), 106-124.

${ }^{96}$ Although a party organ, The Globe has been included in this study primarily because of its association with Reform Party leader and key Confederation delegate George Brown.
} 
opinion as the other newspapers in this study. Despite such a short press run, the Palladium will be employed for two reasons. First, as labour historian and union supporter Ron Verzuh has argued in his study of the nineteenth-century pioneer labour press in Canada, the Palladium of Labor represented the "cream of $19^{\text {th }}$-century labour journals." ${ }^{97}$ The Palladium's circulation figures reflected this quality: on average, it managed to distribute five thousand to seven thousand copies per issue. ${ }^{98}$ Because these numbers handily eclipsed the circulation counts of all other nineteenth-century Canadian labour newspapers, its opinions perhaps most convincingly reflected those of Canada's labouring class during this period. ${ }^{99}$ Second, most nineteenth-century Canadian labour newspapers had rather short lifespans. Indeed, the Palladium's four-year existence was longer than most. Consequently, no nineteenth-century labour journal existed long enough to span two pieces of nineteenth-century federal franchise legislation. Because this study would be incomplete without the inclusion of labour's opinion, it employs the Palladium as arguably its best representative. The Brandon Mail has been selected for somewhat similar reasons. Like the nineteenth-century Canadian labour press, nineteenth-century Manitoban newspapers did not seem to survive for extended periods of time. Aside from the Manitoba Free Press (which this study has also included), the Brandon Mail represented one of the longest running. Its presses started in 1883 and it ceased publication in May of 1897, just nine months before the Liberals tabled their franchise bill. As such, the Mail's existence did not technically bridge the two franchise acts of 1885 and 1898. Still, even in 1897, its editor provided space to discuss franchise

\footnotetext{
${ }^{97}$ Ron Verzuh, Radical Rag (Ottawa: Steel Rail Publishing, 1988), 50.

${ }^{98}$ Ibid., 51.

${ }^{99}$ According to Verzuh, the Palladium's closest competitor at the time, Toronto's Trades Union Advocate, boasted a circulation of a mere "several hundred". See: Verzuh, $47 ; 51$.
} 
legislation. For this reason, and for the general lack of longer-running Manitoban papers, the Mail has been added to the list. With these sources in hand, the following pages will attempt to understand and explain the radical changes within Canada's federal franchise legislation between 1867 and 1898 . To fully account for nineteenth-century Dominion franchise development, however, this study must chronologically return to the period just before Confederation and the swirling debates that resulted in the Dominion's first franchise law. Armed with this methodology and challenged to produce a multivarious analysis of nineteenth-century Dominion franchise reform, our investigation may now commence. 


\section{Chapter 2}

\section{"Every man who now has a vote...should continue to have a vote": The Confederation Franchise of 1867}

By the beginning of 1866 , the process for shaping Canada's confederation was well underway. Representatives from all the British North American colonies had met in Charlottetown, Prince Edward Island, two years earlier, with the blessing of the British Colonial Office, to first discuss the scheme. A few months later, toward the end of September, 1864, the confederation delegates hammered out a draft constitution in Quebec City. In early 1865 , the United Province of Canada agreed in principle with the plan of a federal union. Very soon, the provinces of Nova Scotia and New Brunswick would get on board as well. Still, the confederation was by no means settled. Delegates still had to travel to England to draft the final British North America Act and get it approved by both the British House of Commons, and the House of Lords. At any one of these steps, those resolutions decided upon in Canada could undergo any number of alterations or setbacks, as the voters of New Brunswick were about to demonstrate. While interested individuals on both sides of the Atlantic understood that the new nation would generally establish itself upon British principles of governance, the particulars of confederation still floated in the balance. Onlookers were curious as to the final form of Canada's inaugural institutions. Mr. Alex MacWhorter, a New Jersey-born Episcopalian clergyman hailing from New Haven, Connecticut, represented one such onlooker. ${ }^{1}$

\footnotetext{
${ }^{1}$ In the letter, the author signs off as merely "A. MacWhorter". The 1870 United States federal census provides his full name, place of birth, and occupation. See: United States, Ninth Census of the United States, 1870 (Washington, D.C.: National Archives and Records Administration, 1870), TI 32, RG 29, roll 593_109, page 2 (New Haven Ward 1, New Haven, Connecticut).
} 
Writing on March 20,1866, Alex MacWhorter sought to thank an acquaintance of his - a Mr. A. J. (James) Williamson, John A. Macdonald's brother-in-law ${ }^{2}$ - for some political literature concerning Canada. ${ }^{3}$ Aside from the information contained within such cross-border correspondence, MacWhorter acknowledged that he was "quite unacquainted with the details of [Canada's] affairs". ${ }^{4}$ Despite his admitted ignorance, MacWhorter believed that he had "a right to feel an interest in Canada". ${ }^{5}$ As he told his Canadian contact, he (like so many other northern Americans at the time) had a clear familial connection with British North America: his "Uncle, Gerard Jamie[?] Bolton (deceased)[,] when Col. of Royal Engineers[,] constructed the Rideau Canal, \& [he thought] had something to do with the laying out of the city of Ottawa." ${ }^{.6}$ MacWhorter related that Ottawa even had "a street wh[ich] bears his name - Bolton Street." While the Fenian threat against Canada from Irish expatriates in the United States had captured his attention, the upcoming confederation scheme had come to fascinate him as well. ${ }^{8}$ of

${ }^{2}$ A professor of political science at Queen's University, Williamson married Macdonald's sister Margaret in 1852. According to John A. Macdonald's most recent biographer, journalist Richard Gwyn, Williamson, "although bookish and humourless, was well liked by colleagues and students" as well as Macdonald himself. See: Richard Gwyn, John A.: the man who made us: the life and times of John A. Macdonald, vol. 1 (Toronto: Random House Canada, 2007), 133-134.

${ }^{3}$ Library and Archives Canada [LAC], Sir John A. Macdonald fonds, MG 26-A, "Political papers. Subject files" series, volume 57, reel C1507, page 22832, letter from Mr. A. MacWhorter to Mr. A. J. Williamson, 20 March 1866.

${ }^{4}$ Ibid., 22834.

${ }^{5}$ Ibid.

${ }^{6}$ Ibid.

${ }^{7}$ Ibid.

${ }^{8}$ Formed in the late 1850 s, the Fenian movement organized itself around one key desire: Irish independence from Great Britain. Comprised of Irish immigrants to North America, the Fenians viewed attacks against British territorial possessions in North America (in other words, the British North American colonies) as one way of forcing the British to release Ireland. The year before Confederation, the Fenians attempted two cross-border raids into Canada: one at Campo Bello Island, New Brunswick; and, the other at Niagara. While combined British and American forces at the New Brunswick border effectively forced the Fenians to abort their raid at Campo Bello in May of 1866, the brotherhood managed to advance across the Niagara River into Canada in June of the same year. Canadian militia and British infantry repelled the invaders at Ridgeway, Ontario - approximately twenty kilometres from the Canadian-American border. See: Hereward Senior, The Fenians and Canada (Toronto: Macmillan, 1978), 90-95; 99-106. 
the institutions that the new nation would establish, however, one interested him more than all else: the electoral franchise.

With the Dominion franchise not yet set in stone, MacWhorter wanted his friend to know exactly where he stood on the matter. In the two decades before MacWhorter penned his letter, most American states had undertaken a radical expansion of their state franchises to the point of introducing universal manhood suffrage. ${ }^{9}$ Connecticut had done so in $1845 .^{10}$ Moreover, by March of 1866 , franchise reform had come to occupy the English Parliament. Despite the much more conservative nature of English society when compared with that of the United States, Benjamin Disraeli's Second Reform Act would significantly expand the number of Englishmen who had access to the vote upon its passage in $1867 .{ }^{11}$ Mr. MacWhorter, however, disagreed with such egalitarian pursuits. To him, the franchise represented a "privilege" earned by those "who have a genuine interest \& stake in their own country", and not a right exercised by just anyone who demanded it. ${ }^{12}$ To protect the nation from negative outside influences, he believed most adamantly in the "absolute necessity $\&$ security of confining suffrage to those alone

${ }^{9}$ According to Harvard historian Alexander Keyssar, twenty-nine of the thirty-one states that existed in 1855 had abolished their property qualifications for the franchise. Rhode Island and South Carolina represented the sole two that resisted universal democracy and manhood suffrage. See: Keyssar, 342-347.

${ }^{10}$ See: Ibid., 342 (Table A.2)

${ }^{11}$ Liberal Prime Minister Lord John Russell first introduced a franchise reform bill in March of 1866. The bill soon failed, Russell's Liberal ministry resigned as a result, and Lord Derby's Conservative party took the reigns of office. As Chancellor of the Exchequer under Derby, future Prime Minister Benjamin Disraeli introduced the bill that would eventually become the Second Reform Act in February of 1867. It reduced residence the residence requirement for the franchise from three years to one, it allowed lodgers the vote (so long as they paid at least $£ 10$ per year), and made some extensions to the county franchise. All in all, as Catherine Hall, Keith McClelland, and Jane Rendall explain, "the privileges in citizenship were extended far beyond the 'Select few'..." See: Hall et al., 1; 4-5. The following chapter will discuss the Second Reform Act in much greater detail.

${ }^{12}$ LAC, Mr. A. MacWhorter to Mr. A. J. Williamson, 22832; 22833. 
who have a stake in the country." ${ }^{13}$ Mr. MacWhorter's ideas were by no means novel. The belief that voters should possess a stake in the nation through real property had held sway in the inchoate democracies of Europe and America. Perhaps first elaborated upon during the mid-eighteenth century by the French political theorist Charles de Secondat, Baron de Montesquieu, this view of property as an anchor to democracy had retained its ascendant popularity amongst most of the Western democracies through to the midnineteenth century. ${ }^{14}$ (Only the United States and France had ventured to abolish their property qualifications for the franchise. $)^{15}$ While MacWhorter upheld such ideas with regard to his homeland, he apparently felt they applied just as readily to Canada. Indeed, he "hope[d] to see the new Confederation of Canada avoid the fearful enfranchisement of unqualified suffrage wh[ich] we [Americans] are trying." ${ }^{\prime 16}$ These words should have left no doubt in A. J. Williamson's mind: his Connecticut associate profoundly desired those responsible for confederation would see fit to invoke a restrictive federal franchise for the good of the new Canadian nation. But, would Mr. MacWhorter have his wish granted? Or, would Canada follow the lead of its estranged sister to the south?

Of course, Canada's inaugural federal franchise did not emerge from a vacuum. Even someone as distantly informed of the state of Canadian institutions in 1866 as $\mathrm{Mr}$. MacWhorter should have known that the British North American colonies had maintained representative institutions for quite some time. With these representative

\footnotetext{
${ }^{13}$ Ibid., 22833-22834. Emphasis in text.

${ }^{14}$ For his discussion on the fitness of individuals to exercise the vote, refer to Montesquieu's classic text of 1748, The Spirit of the Laws: Charles de Secondat, Baron de Montesquieu, The Spirit of the Laws, vol. 1, trans. Thomas Nugent (New York: Hafner, 1949), 155. Montesquieu's philosophy will be discussed in more detail later in this chapter.

${ }^{15}$ The French first employed universal manhood suffrage in 1792 to elect the National Convention during the French Revolution. While the French abandoned manhood suffrage after the Revolution, the Second French Republic, soon after its formation, reinstituted it in 1848.

${ }^{16}$ LAC, Mr. A. MacWhorter to Mr. A. J. Williamson, 22833. Emphasis in text.
} 
governments - first established in Nova Scotia in 1758, followed by Prince Edward Island, New Brunswick, and Upper and Lower Canada in 1773, 1785, and 1792 respectively - came franchise laws to provide for the election of such governments. ${ }^{17}$ Needless to say, these colonial franchises underwent a series of alterations and reforms themselves under the pressure of ideological ferment and demographic expansion. ${ }^{18}$ By the time of confederation, however, the statute books showed these franchises as clearly set. In 1854, the Nova Scotia legislature, at the behest of Attorney General James William Johnston, had decided to experiment with manhood suffrage. ${ }^{19}$ As the Toronto Globe wrote, it had done so "in the hopes of obtaining relief from the corruptions attendant upon the existing law, involving property qualification." ${ }^{, 20}$ Electoral fraud had plagued the previous legislative election in 1851 . To underhandedly receive a ballot, disenfranchised individuals had both tampered with the assessment rolls and forged tax collection receipts to make it appear as if they owned property. ${ }^{21}$ The legislature apparently viewed the elimination of property qualifications as the swiftest way of eliminating such widespread corruption. ${ }^{22}$ By 1863 , however, the experiment had ended, and mainly for partisan purposes. To curry the favour of Nova Scotia's Protestant

${ }^{17}$ Elections Canada, 3-4.

${ }^{18}$ The first chapter of $A$ History of the Vote in Canada (entitled "British North America 17581866") outlines the changes to the British colonial franchises. For more in-depth description and explanation, however, see John Garner's much earlier work, The Franchise and Politics in British North America 1755-1867.

${ }^{19}$ Garner, 31-32. A solicitor by training, Johnston was oddly enough a solid Tory politician. Despite his staunch anti-democratic impulses and his generally cautious nature, he advanced his manhood suffrage bill with such tenacity that it passed the Liberal majority in the provincial legislature. See: D. A. Sutherland, "Johnston, James William", Dictionary of Canadian Biography, vol. X, ed. Marc La Terreur (Toronto: University of Toronto Press, 1972), 386-388; Garner, 32.

20 "Manhood Suffrage in Nova Scotia," Toronto Globe, 13 April 1863, 2.

${ }^{21}$ Garner, 30.

22 John Garner argues that as a result of such corruption, "the public witnessed a 30 per cent increase in the vote cast in the general election of 1851 as compared with the previous election of $1847 . "$ See: Ibid. 
population - owners of most of the province's real estate - Liberal leader Joseph Howe reportedly sought to disenfranchise the colony's generally less-propertied Catholic voters (mainly Irishmen who for the most part supported the Conservatives). Since Nova Scotia's Catholics tended to work as labourers and did not own real property, the reinstitution of a property qualification had Howe's desired effect. ${ }^{23}$ Aside from being a male who had reached the age of majority of twenty-one year, a Nova Scotian voter in 1863 now had to own at least $\$ 150$ worth of real property or $\$ 300$ worth of personal and real property combined to cast a vote. ${ }^{24}$ This franchise, spurred on by class and partisan impulses rather than a democratic urge, would remain on the statute books in Nova Scotia until well after confederation. ${ }^{25}$

In New Brunswick, ${ }^{26}$ on the other hand, a property qualification had always been in effect. As of 1855 , a man had to own real estate assessed at $£ 25$ or more for his enfranchisement. ${ }^{27} \mathrm{He}$ could also receive the vote if he earned at least $£ 100$ in annual income. ${ }^{28}$ Historians have generally quadrupled these values to arrive at equivalent amounts in Canadian dollars (in other words, a potential voter required the equivalent of

${ }^{23}$ Ibid., 34 .

${ }^{24}$ Nova Scotia, The Statutes of Nova Scotia, passed in the Fourth Session of the General Assembly of the Twenty-sixth Reign of Her Majesty Queen Victoria, held on the Twelfth Day of February, 1863

(Halifax: E. M. McDonald, Queen's Printer: 1863), 50.

${ }^{25}$ In 1885, Nova Scotia's legislature passed The Franchise Act, 1885. For details of the act, see: Thomas Hodgins, The Canadian Franchise Act, with Notes of Decisions on the Imperial Acts Relating to Registration, and on the Provincial Franchise and Election Acts (Toronto: Boswell and Hutchinson, 1886), 190-193.

${ }^{26}$ Prince Edward Island has been removed from this list because it pulled out of the confederation talks soon after the Charlottetown conference in 1864. Out of all the British North American colonies at the time, Prince Edward Island maintained the least strict franchise qualifications. As long as a male Prince Edward Islander had reached the age of twenty-one, had lived on the Island for at least one year, and had provided four days' labour to the province (or the cash equivalent) for road maintenance, he could legally cast a ballot in the legislative elections. See: Elections Canada, 15.

${ }^{27}$ Garner, 72.

${ }^{28}$ Elections Canada, 18. 
$\$ 100$ in real property or a quite substantial $\$ 400$ yearly income).$^{29}$ In the central Canadas, franchise qualifications were the same for much of the $1860 \mathrm{~s}^{30}$ Alongside the age and sex requirements stipulated by the other colonies, franchise law required rural residents to either own or lease land worth at least $\$ 200$. Urban Canadians, in contrast, had to own or lease $\$ 300$ of real property. ${ }^{31}$ In 1866 , however, Upper Canada instituted new qualifications for its voters. While John Sandfield Macdonald's Ontario government would largely reverse these changes the year after confederation, ${ }^{32}$ the 1866 Upper Canadian suffrage legislation introduced perhaps the highest property qualifications in Canadian history: $\$ 600$ for city dwellers, $\$ 400$ for town inhabitants, $\$ 300$ for those who lived in incorporated villages, and $\$ 200$ for township residents. ${ }^{33}$

Taking all of these qualifications and exclusions into account, one can see certain trends that ran through the pre-Confederation franchises. First, no matter where one travelled in British North America, only males who had reached the age of majority could receive the ballot. Such qualifications would in fact remain in effect at the federal level throughout the rest of the nineteenth century, and even into the early twentieth century. ${ }^{34}$ Second, the British North American colonies that would enter into the union in 1867 all maintained quite restrictive franchises. The average salaries earned by Canadians at the time speak to this. For example, a highly skilled worker such as a Saint John, New

${ }^{29} \mathrm{Ibid} ., 46$.

${ }^{30}$ By this time, Upper Canada had been renamed Canada West and Lower Canada renamed Canada East. For the sake of clarity, this paper will use the terms Upper Canada and Lower Canada to refer to pre-Confederation Ontario and Quebec. Most contemporary nineteenth-century Canadians used the same terms as well.

${ }^{31}$ Ibid., 33.

${ }^{32}$ Franko, 108-109. A Liberal politician from Upper Canada and an anti-unionist, John Sandfield Macdonald would become Ontario's first premier. For more on J. S. Macdonald, see: Bruce W. Hodgins, “Macdonald, John Sandfield", Dictionary of Canadian Biography, vol. X, 462-469.

${ }^{33}$ Elections Canada, 33.

${ }^{34}$ While the age of majority would remain at twenty-one until 1970 (when it was reduced to eighteen), Canadian women received the federal vote for the first time in 1917. See: Ibid., 92; 67-68. 
Brunswick shipbuilder, earned on average one dollar per day in 1865 , and no more than $\$ 300$ per year. ${ }^{35}$ Slightly later, in 1871 , skilled workers in Toronto, such as butchers, millwrights, plumbers, and cotton carders and weavers, would have also expected to make one dollar per day. ${ }^{36}$ After paying for essentials such as food and fuel for their families, very few of these Canadians would have been able to procure the amount of property necessary to receive the franchise, especially in Upper Canada. ${ }^{37}$ While electoral statistics from this time should be considered tentative at best, John Garner has argued that as of the early 1860s (before Upper Canada elevated its franchise qualifications to their astronomic 1866 level) approximately ten to twelve percent of

${ }^{35}$ Ibid., 17.

${ }^{36}$ M. C. Urquhart and K. A. H. Buckley, eds., Historical Statistics of Canada, (Toronto: Macmillan, 1965), 94. That same year, skilled workers in Nova Scotia would have expected to earn similar wages to their counterparts in Toronto. According to Julian Gwyn and Fazley Siddiq, these skilled labourers earned on average $\$ 1.05$ per day. The unskilled (or "common") Nova Scotian labourer, however, earned far less in 1871: only $\$ 0.64$ per day. Nova Scotians who worked as school teachers - an expectedly more educated position - received similarly debased wages. They, on average, earned an annual salary of $\$ 133$ in 1871. See: Julian Gwyn and Fazley Siddiq, "Wealth Distribution in Nova Scotia during the Confederation Era, 1851 to 1871," Canadian Historical Review 73.4 (December 1992): 451-452.

${ }^{37}$ Costs of living for nineteenth-century Canadians still remain largely unknown. Considering these costs would change with the size, composition, and geographical location of each family, the historian's task in making such determinations becomes all the more difficult. That said, one can posit certain generalizations that help illuminate these costs. University of Guelph historian J. G. Snell has put together perhaps the best compilation of mid-nineteenth-century Canadian prices for essential foodstuffs (taking in to account the cities of Ottawa, Hamilton, Brantford, Chatham, St. John, Fredericton, and Quebec). According to his price tables, in 1870, a staple such as eggs cost anywhere between twelve to twenty-two cents per dozen. If a skilled labourer earned on average one dollar per day, twelve eggs alone would cost him ten to twenty-five percent of his daily wage. Moreover, according to Snell's tables, a pound of butter could cost anywhere from eighteen to twenty-four cents in these cities. In larger cities, the price of butter could reach even higher. For example, Joel Miller \& Brother, in the price circular of 25 November 1869 for their Toronto-based dry goods company, sold butter for anywhere between twenty-five and thirty-nine cents (while the circular does not say for what quantity, one can assume it means per pound). At these prices, butter could cost a skilled labourer twenty to forty percent of his daily salary depending upon where he happened to live. With food expenses so high - and the need to pay for heating fuel, lighting fuel, clothing, and accommodations on top of that - one could not expect many skilled labourers to own their own land. See: J. G. Snell, "The Cost of Living in Canada in 1870", Histoire Sociale: Social History 1979 12(23), 190; "Joel Miller \& Brother, West Enterprise, November 25 Produce Circular and Prices Current", (Toronto: s.n., 1869). In her text Working Families (originally published in 1993), York University historian Bettina Bradbury attempted to determine the cost of living for working families in industrializing Montreal. While her statistics refer to a later date (1882), she argues that a family of five (with a boy aged sixteen, and two girls aged fourteen and eight) would exhaust a labourer's annual salary on essentials alone. See: Bettina Bradbury, Working Families: Age, Gender, and Daily Survival in Industrializing Montreal (Toronto: University of Toronto Press, 2007), 93 (Figure 3.1). 
British North Americans exercised the franchise. ${ }^{38}$ Considering the electorate today consists of sixty-seven percent of the total Canadian population, these colonial numbers appear remarkably low. ${ }^{39}$ Because of their restrictiveness and their emphasis on property, the British North American franchises would have undoubtedly pleased individuals such as Connecticut's Alex MacWhorter. They also provided a readily accessible template for the colonial delegates responsible for drawing up the articles of confederation. Whether they chose to follow that template was another matter altogether.

Despite their momentous undertaking, the delegates to the confederation discussions only kept the scantiest of minutes to the Charlottetown conference in 1864 and their gathering at Quebec City later that year. In his recent biography of Sir John A. Macdonald, Richard Gwyn discusses the accounts that do exist for the two conferences. For the Charlottetown conference, Reform party leader George Brown wrote almost daily

${ }^{38}$ Garner, 217 (endnote 2). As $A$ History of the Vote in Canada has mentioned, readers should take statistical pronouncements about the nineteenth-century Canadian franchises with a grain of salt because of the largely unreliable statistics kept for nineteenth-century elections. See: Elections Canada, 50. Garner, to his credit, prefaces his numbers in stating that "The statistics of populations and vote returns are fragmentary and do no permit a conclusive assertion." Indeed, he had to rely upon voter turnouts to compile his statistics. As such, his figures reflect only the number of people who voted instead of the number of people who the provinces had enfranchised. Still, Garner represents the only person to attempt a statistical breakdown of the British North American colonial franchise. See: Garner, 217 (endnote 2). To arrive at the conclusion that ten to twelve percent of the colonists had the vote in 1861 , this paper could unfortunately solely rely upon data from Upper Canada, Lower Canada, and New Brunswick (where reportedly 9.5 percent and 11.6 percent of the population exercised the franchise respectively). While Garner only supplied statistics for Nova Scotia's experiment with manhood suffrage (where 21.6 percent of the population reportedly voted), Nova Scotia's subsequent property qualifications would have undoubtedly lowered the percentage of the population enfranchised.

${ }^{39}$ Elections Canada, 99. As mentioned in the preceding chapter, Gail G. Campbell (by means of her case study of Albert County, New Brunswick) has argued that "[ $t$ ]he suffrage had not yet become a universal right, accorded to all voting-aged males, but it was, nonetheless, a right that the vast majority of young men could realistically expect to gain, and to gain legally." Earlier in the article, Campbell mentions to the reader that "[t]he major occupation in the county was farming". She also relates that "[f]armers, by virtue of their very dependence on the land, were more often prepared to make sacrifices to secure a freehold" and, therefore, much more likely to own land. As such, Campbell's choice of county for her case study may have skewed her findings to make the franchise more inclusive than it was. The study of a more urban riding would have probably revealed a greater disparity between the enfranchised and the disenfranchised. See: Campbell in Canadian Historical Review, 165; 176; 188. 
letters to his wife Anne. ${ }^{40}$ Unfortunately, the letters tended to deal "not with politics but with people.” As for Quebec, “Official minutes were kept by [John A.] Macdonald's deputy minister, Hewitt Bernard, but they were prosaic and terse. Unofficial and abbreviated notes were taken by Prince Edward Island delegate, A. A. Macdonald..." While those notes that exist from Charlottetown make no mention of the franchise, Hewitt Bernard's minutes from Quebec City happily make such a reference. ${ }^{41}$ Even so, Bernard's summary reveals very little: only that the delegates discussed the franchise question during the morning session of October 20, 1864, that John A. Macdonald Conservative politician, the chairman of the Quebec Conference, the man credited with penning fifty of the seventy-two resolutions himself, and, soon, the first Prime Minister of Canada - made the motion concerning Canada's new franchise, and that those present in Quebec unanimously agreed to it. ${ }^{42}$ Macdonald's resolution read as follows:

Until provisions are made by the General Parliament, all the laws which at the date of the Proclamation constituting the Union are in force in the Provinces respectively, relating to the qualification and disqualification of any person to be elected or to sit or vote as a member of the Assembly in the said Provinces respectively; and relating to the qualification or disqualification of voters, and to returning officers and their powers and duties; and relating to the proceedings at elections, and to the period during which such elections may be continued; and relating to the trial of controverted elections, and the proceedings incident thereto; and relating to the vacating of seats of members, and the issuing and execution of new writs in case of any seat being vacated otherwise than by a dissolution, shall respectively apply to elections of members to serve in the House of Commons, for places situate in those provinces respectively. ${ }^{43}$

${ }^{40} \mathrm{Gwyn}, 302-303 ; 315$. In Upper Canada, the Reform party was the precursor to the postConfederation Liberal party.

${ }^{41}$ A. A. Macdonald's minutes, however, make no mention of the franchise whatsoever.

42 "Hewitt Bernard's Minutes of the Quebec Conference, 10-29 October, 1864," 20 October 1864, in G. P. Browne, ed., Documents on the Confederation of British North America (Toronto and Montreal: McClelland and Stewart, 1969), 74-75. Richard Gwyn writes that Macdonald's Conservative ally, Irish expatriate, and Confederation delegate Thomas D'Arcy McGee credited Macdonald with penning the fifty resolutions. See: Gwyn, 311.

${ }^{43}$ Ibid. 
In other words, those present in Quebec City had agreed that they should employ the existing colonial franchises as the basis for the new Dominion franchise. Macdonald's resolution eventually became the twenty-sixth of the famed seventy-two resolutions that represented the final outcome of the Quebec Conference. ${ }^{44}$ While Confederation would not take place for another two years, and a conference in London, England still had to take place, the language of this resolution did not change. Enshrined as section forty-one of the British North America Act, it guaranteed that those individuals enfranchised within the soon-to-be Canadian provinces would legally have the vote in upcoming federal elections as well. ${ }^{45}$ But, why did the Confederation delegates adopt this course of action? They most apparently did so out of pure convenience or pragmatism.

At the start of 1865 , the Canadian Legislative Assembly met to determine whether it would endorse the Confederation scheme. The task fell to the delegates who represented Upper and Lower Canada in Quebec to convince their colleagues of its merits. Soon after the debates started, the discussion quickly turned to the sort of franchise the new Dominion would receive. Attorney General John A. Macdonald outlined the pragmatic approach to nation building that those at the Quebec Conference adopted in this regard. According to him, "Insuperable difficulties would have presented

${ }^{44}$ See: Report of resolutions adopted at a conference of delegates from the provinces of Canada, Nova Scotia, and New Brunswick, and the colonies of Newfoundland and Prince Edward Island held at the city of Quebec, October 10, 1864, as the basis of a proposed confederation of those provinces and colonies (London: s.n., 1867?), 4-5.

${ }^{45}$ While the punctuation differs between section forty-one of the British North America Act and resolution twenty-six, the wording remains the same. See: Canada, The British North America act, 1867, and amending acts (Ottawa: s.n., 1890), 19-20. 
themselves if we had attempted to settle now the qualification of electors..."46 Because those at the Quebec Conference arguably had neither the time to fashion new franchise legislation for the Dominion, nor the desire to stir up the contentious topic of the franchise as they delicately negotiated the union, they "therefore adopted a similar clause to that which is contained in the Canada Union Act of 1841, viz., that all the laws which affected the qualification of members and of voters...should obtain in the first election to the Confederate

Parliament, so that every man who has now a vote in his own province should continue to have a vote in choosing a representative to the first Federal Parliament."47 With the

\section{Nineteenth-Century Voting}

The voting process at the time of Confederation was somewhat different from that of today. In the months leading to an election, the government would prepare its voters' lists. These lists contained the names of all those men who would receive a ballot. The task of creating the voters' lists fell to the revising barrister. Each electoral district had its own revising barrister. On election day, those men listed on the voters' lists would present themselves at the hustings.

Waiting his turn amongst the throngs of partisan supporters and interested onlookers, he would present himself to his peers and openly declare his support for the candidate of his choice. Generally, a chorus of cheers and jeers would follow, and possibly a speedy exit if the crowd believed he made a particularly uninformed choice. Prime Minister Alexander Mackenzie ended the era of open voting for Dominion elections in 1874 , when he introduced the secret ballot.

reported agreement that "it [would be] left to the Parliament of the Confederation, as one of their first duties, to consider and to settle by an act of their own the qualification of the elective franchise, which would apply to the whole Confederation", the delegates moved on to more pressing (and perhaps less contentious) matters. ${ }^{48}$ Yet, pragmatism provides only the first, most superficial explanation as to the adoption of the colonial franchises

\footnotetext{
${ }^{46}$ Parliamentary Debates on the Subject of the Confederation of the British North American
} Provinces [Confederation Debates], 3rd Session, $8^{\text {th }}$ Provincial Parliament of Canada (Quebec: Hunter, Rose \& Co., 1865), 39.

${ }^{47} \mathrm{Ibid}$. As the House of Commons debates concerning the Dominion Franchise Act of 1885 will demonstrate, the formation of new franchise legislation could have taken months to accomplish.

${ }^{48}$ Ibid. 
for the inaugural Dominion franchise. Considering the other pronouncements made concerning the franchise during the debates surrounding Confederation, underlying political ideology must have played an equally important, if not more important, role as well.

Over the past fifteen years, the ideological foundation of Confederation has represented a topic of considerable debate. Challenging the orthodox view of past decades that Confederation epitomized a project of Burkean conservatism (as advanced by the preeminent Canadian scholars George Grant and Gad Horowitz), ${ }^{49}$ political scientists and historians such as McMaster University's Janet Ajzenstat and Queen's University's Ian McKay have instead argued that a liberal political philosophy rooted in notions of egalitarianism, progress, and individual rights underpins the Canadian union. ${ }^{50}$ In response, other scholars, such as Athabaska University political scientist Peter J. Smith and Laurentian University historian Andrew Smith, have offered defences of the conventional conservative conception of Confederation. ${ }^{51}$ While some of these scholars briefly mention the franchise in their analyses - such as Ajzenstat, within a broader

${ }^{49}$ See: George Grant, Lament for a Nation (Toronto: McClelland and Stewart, 1965); Gad Horowitz, "Conservatism, Liberalism, and Socialism in Canada: An Interpretation", Canadian Journal of Economy and Political Science 52.2 (May 1966): 143-171.

${ }^{50}$ See: Janet Ajzenstat, "The Conservatism of the Canadian Founders", in After Liberalism: Essays in Search of Freedom, Virtue, and Order, ed. William D. Gairdner (Toronto and New York: Stoddart, 1998), 17-32; Ian McKay, "The Liberal Order Framework: A Prospectus for a Reconnaissance of Canadian History", Canadian Historical Review 81.4 (December 2000), 617-645. For an even more recent work, see: Janet Ajzenstat, The Canadian Founding: John Locke and Parliament (Montreal and Kingston: McGill-Queen's University Press, 2007), xv-xvi.

${ }^{51}$ See: Peter J. Smith, "The Ideological Origins of Canadian Confederation", in Canada's Origins: Liberal, Tory, or Republican?, eds. Janet Ajzenstat and Peter J. Smith (Ottawa: Carleton University Press, 1995), 68-72; Andrew Smith, "Toryism, Classical Liberalism, and Capitalism: The Politics of Taxation and the Struggle for Canadian Confederation", Canadian Historical Review 89.1 (March 2008), 2-25. 
discussion of democratic principles - none of them devote nearly enough attention to it (despite its importance to their arguments). ${ }^{52}$

By the time of Confederation, western conservatives and liberals had already established clearly-defined positions when it came to the franchise. For the conservative stance, one must turn to the so-called father of western conservatism, the aforementioned Edmund Burke. An English Parliamentarian and political philosopher during the second half of the eighteenth century, Burke believed that experience, prudence, efficacy, order, tradition and the ascendency of property should act as the foundation for politics. ${ }^{53}$ In the case of England, the constitution had enshrined a political system based upon representative monarchy. While the lower house debated the desires of Englishmen (and, to a lesser extent, Englishwomen), it fell to the monarch to rule the nation. Through his belief in the ascendency of political tradition, Burke argued that it was not his place to examine "whether the principles of the British (the Irish) Constitution be wise or not": he believed that all Britons "must assume that they are". ${ }^{54}$ Moreover, for Burke, such a constitutional arrangement had allowed his fellow countrymen to receive, inherit, and enjoy the freedoms and liberties they had come to possess. As such, he concluded that any precipitous change to England's political system would be highly unwise. Of all these potential changes, however, he most despised the institution of republicanism,

${ }^{52}$ See: Ajzenstat in After Liberalism, 26. More specifically, Ajzenstat states that despite the fact that John A. Macdonald and George-Étienne Cartier "express[ed] doubts about the further extension of the franchise", they actually supported liberal democracy. Ajzenstat never reveals where Macdonald and Cartier expressed these doubts.

${ }^{53}$ While generally identified as a conservative today, Burke was actually a Whig in the English Parliament (as opposed to the more conservative Tories). If anything, this speaks to the complexity of Burke's political philosophy.

${ }^{54}$ Edmund Burke, "A Letter to Sir Hercules Langrishe, Bart., M.P., on the Subject of The Roman Catholics of Ireland and The Propriety of Admitting Them to the Elective Franchise, Consistently with the Principles of the Constitution, as Established at the Revolution" (1792), in The Works of the Right Honourable Edmund Burke (London: John C. Nimmo, 1899), 253. 
otherwise known as universal democracy, and its confidence in manhood suffrage. Instead of the monarch ruling through the legislative assembly for the good of the nation, universal democracy creates a system where (in Burke's view) the many rule from below, embracing their "idleness and profligacy" and the "corruption of manners". ${ }^{55}$ In instituting such a system, as the French reportedly did through their revolution in 1789, the people ungenerously rebuke all the good representative monarchy had done for the nation and disinherit the freedoms bestowed upon them. ${ }^{56}$

For Burke, the property-based franchise represented a pivotal element of the British constitution. Indeed, ever since England adopted parliamentary institutions, it had relied upon a suffrage based upon the ownership of real property. As a traditionalist, one may think that Burke would have fought against any changes to this material base to political action. Interestingly, this was apparently not the case. Burke understood that some Englishmen of the mid-eighteenth century believed that the nation had too few voters. ${ }^{57}$ These Englishmen desired an expansion of the franchise in the same direction the French would take at the end of the century (but perhaps not to the same extent). According to Burke, such an alteration to the franchise should be out of the question. As he stated: "I believe that most sober thinkers on this subject are rather of opinion, that our fault is on the other side; and that it would be more in the spirit of our constitution, and more agreeable to the pattern of our best laws, by lessening the number [of voters], to add to the weight and independency of our voters. ${ }^{958}$ Since the ownership of property traditionally conferred one's political independence, the conservative Burke believed that

\footnotetext{
${ }^{55}$ Burke, "The Present State of the Nation", in Ibid., 371.

${ }^{56}$ Edmund Burke, Reflections on the Revolution in France, ed. J. C. D. Clark (Stanford: Stanford University Press, 2001), 288-299.

${ }^{57}$ Ibid.

${ }^{58}$ Ibid., 370-371.
} 
the state should make it as precious a right as possible. He consequently deemed that the franchise should at the very least remain as restrictive as before. The spirit of the constitution demanded that much. But, if one must reform the franchise, Burke asserted that any alterations must take the form of restrictions. For him, the good of the nation required nothing less.

Considering British North Americans commonly knew John A. Macdonald's party as the Conservative party, one would think that Macdonald and his allies would have prescribed to Burke's view of the franchise. Undoubtedly, the biographical literature on contemporary Conservative luminaries tends to support such a hypothesis. While former Wilfrid Laurier University political scientist Rod Preece has argued that Canadians should "regard Macdonald as the statesman embodiment of the principles of Burkean philosophy," University of Toronto historian David A. Wilson has used similar language to describe Thomas D'Arcy McGee. ${ }^{59}$ In his recent biography of McGee Canada's Minister of Agriculture in 1865, a Confederation delegate, and the Conservative party's most eloquent representative - Wilson intimates that " $[t]$ he connecting figure, the man who loomed largest in McGee's intellectual world, was undoubtedly Edmund Burke." ${ }^{.00}$ With such strong assertions of individual Conservatives' Burkean values, it is unsurprising that the Conservatives appear to adhere quite closely to Burkean conservatism upon examining their remarks concerning the franchise. Such

${ }^{59}$ Rod Preece, "The Political Wisdom of Sir John A. Macdonald", Canadian Journal of Political Science 17.3 (September 1984), 486.

${ }^{60}$ David A. Wilson, Thomas D'Arcy McGee: Passion, Reason, and Politics 1825-1857, vol. 1 (Montreal and Kingston: McGill-Queen's University Press, 2008), 25. Wilson writes that "As a young man himself, McGee had held ambivalent views about Burke's political science." By 1865 (and the Confederation debates), however, "McGee had not only dropped but reversed his criticism" of Burke and promoted Burkean political philosophy. See: Ibid. 
sentiments were first evident in Macdonald himself - the man who apparently penned the franchise resolution at Quebec - and then received the endorsement of those around him.

Even as early as 1858 , Attorney General Macdonald had declared to the Upper Canadian Legislative Assembly that "he was not in favour of universal suffrage but completely opposed to it." ${ }^{\prime 61} \mathrm{He}$ later built upon this sentiment in 1861 in front of the Canadian Legislative Assembly when he argued that to prevent "anarchy and despotism...property [must be] protected and made one of two principles on which [legislative] representation was based..."62 By 1865, Macdonald had not changed his tune in any way. As part of the discussions concerning Confederation, he reported that the delegates had deliberated upon the popular notion of representation by population. ${ }^{63}$ Still, Macdonald felt that his statement required a disclaimer. "When [he spoke] of representation by population", Macdonald confirmed, "the House will of course understand, that universal suffrage is not in any way sanctioned, or admitted by these resolutions, as the basis on which the constitution of the popular branch [of government the House of Commons -] should rest." ${ }^{24}$ In fact, Macdonald went on to speak not only for himself but for the other thirty-one men present at Quebec (including those representing the Atlantic colonies) when he declared that "not a single member of the Conference, as I stated before, not a single one of the representatives of the government

\footnotetext{
61 "House of Assembly," Toronto Globe, 12 May 1858, 2.

${ }^{62}$ Canada, Debates of the Legislative Assembly of United Canada, 19 April 1861. Cited in: Preece in Canadian Journal of Political Science, 472.

${ }^{63}$ In the Canadian context, those who uphold the principle of representation by population (or what contemporaries commonly referred to as 'Rep. by pop.') believe that each province should have as many seats in the House of Commons as warranted by its population figures. Consequently, upon the formation of Canada, Ontario and Quebec would have more seats than less populated provinces such as Nova Scotia and New Brunswick. As Norman Ward relates, "nothing emerges more emphatically from the Confederation negotiations then the insistence of Upper Canada" on representation by population (because it would receive the most seats by virtue of its larger population). See: Ward, 22.

${ }^{64}$ Confederation Debates, 35.
} 
or of the opposition of any one of the Lower Provinces was in favour of universal suffrage.,"65 If Macdonald had his way, manhood suffrage would not arrive in Canada any time soon.

To justify his stance, Macdonald echoed and expanded upon his earlier statement of 1861. Standing before the Legislative Assembly, he declared to his peers that "[i]n all countries the rights of the majority take care of themselves, but it is only in countries like England, enjoying constitutional liberty, and safe from the tyrany [sic] of a single despot or of an unbridled democracy, that the rights of minorities are regarded. So long, too, as we form a portion of the British Empire, we shall have the example of her free institutions..." S66 Such a contention (and its stance toward universal democracy, traditional British political institutions, and, most importantly, manhood suffrage) followed Burke's conservative arguments almost to the letter. ${ }^{67}$ Like Burke, Macdonald apparently saw the value in abiding by political institutions that had proven themselves through the test of time.

A British loyalist at heart, Macdonald, throughout his life, reportedly remained "fiercely loyal" to Great Britain's law and its institutions, "never having the least doubt [they were] far superior to that of any other nation". 68 Macdonald "the great loyalist" may have consequently had an instinctual attraction to English institutions such as

${ }^{65}$ Ibid., 39.

${ }^{66}$ Confederation Debates, 44.

${ }^{67}$ In a very recent chapter discussing the notion of rights within nineteenth-century Canada, McGill University historian Elsbeth Heaman similarly connects John A. Macdonald's philosophy regarding the franchise with that of Burkean conservatism. See: E. A. Heaman, "Rights Talk and the Liberal Order Framework", in Liberalism and Hegemony: Debating the Canadian Liberal Revolution, eds. Jean-François Constant and Michel Ducharme (Toronto: University of Toronto Press, 2009), 150-151.

${ }^{68}$ Gwyn, 152. Macdonald's other biographer, Donald Creighton, also highlights Macdonald's strong loyalty to Great Britain and its political institutions. See: Donald Creighton, John A. Macdonald: The Young Politician (Toronto: Macmillan, 1952), 180. 
English franchise law however. ${ }^{69}$ As his most recent biographer, Richard Gwyn, relates, "there was no deference in his posture": Macdonald was loyal, but not unthinkingly so. ${ }^{70}$ The fact that British institutions (as developed and employed over the centuries) so clearly met the needs of that nation therefore justified his support for them. Since the "tyrany $[s i c]$ of a single despot or of an unbridled democracy" would radically displace these institutions (and the benefits they bestowed), Macdonald, like Burke, evidently could not support such departures from tradition whatsoever. ${ }^{71}$ As one of these English institutions, the restrictive, property-based franchise had seemingly served England well since it had adopted representative government. ${ }^{72}$ It had apparently preserved the audibility of minority voices from the mob's cacophony; and, it had ostensibly prevented the kind of sectarianism that could tear a nation apart (so important when attempting to form a delicate federal union). Prudence therefore dictated that Canada should not stray from a franchise already proven effective. If the ownership of property had apparently guaranteed the steady judgement of voters in the past, one would assume that it would do so in the future as well. Indeed, just as Burke encouraged, Macdonald's resolution concerning Canada's inaugural franchise suggested no changes at all to the size of the federal electorate as conceived by the provinces. As a result, it appears that Macdonald both composed and heartily endorsed a piece of federal franchise legislation seemingly formed from Burke's conservative mould. Yet, Macdonald left his argument incomplete. While he warned the Legislature of the tyranny of "unbridled democracy", he never fully clarified why universal democracy and its reliance on manhood suffrage are so

\footnotetext{
${ }^{69}$ Gwyn, 366

${ }^{70}$ Ibid., 368.

${ }^{71}$ Again, refer to: Confederation Debates, 44.

${ }^{72}$ See: Jon Roper, Democracy and Its Critics (London: Unwin Hyman, 1989), 116-123.
} 
tyrannical. Embedded with the Victorian Tory political mindset, he may have simply assumed that his peers would have instinctively understood his argument. Macdonald therefore left it to his Conservative allies to give such an explanation.

In the following days, Attorney General Macdonald's Conservative colleagues took their turns to address the Legislative Assembly. Of these allies, Macdonald's Lower-Canadian counterpart, Attorney General George-Étienne Cartier, was first to speak. A pragmatic Conservative himself, he spoke for French Canada in Macdonald's Conservative party. Despite his Canadien and Patriote roots, ${ }^{73}$ Cartier's love for Great Britain reportedly rivalled even that of Macdonald (despite his Canadien heritage). ${ }^{74} \mathrm{He}$ had named one of his daughters Reine-Victoria; he viewed himself as "an Englishman who speaks French"; and, he had planned in his retirement to "settle [himself] in London". ${ }^{75}$ As historian Jacques Monet has argued, bleu nationalism in Quebec was rooted in an appreciation of the power of representative parliamentary democracy to shield minorities. ${ }^{76}$ Consequently, he wholeheartedly agreed with Macdonald that "In our Federation the monarchical principle [and its respective institutions] would form the leading feature". ${ }^{77}$

Cartier contrasted these decidedly British institutions with those established south of the border in the United States. According to Cartier, "They [the American people] had founded Federation for the purpose of carrying out and perpetuating democracy on

${ }^{73}$ According to Richard Gwyn's recent description of Cartier, "Cartier was wholly and completely Canadien. He was never happier than when belting out voyageur songs at his regular and raucous conversations...In 1834 he was the first secretary of the new Société St-Jean-Baptiste, of which the slogan was "Nos institutions, notre langue, nos droits." See: Gwyn, 179 (emphasis in text).

${ }^{74}$ Alistair Sweeny, George-Etienne Cartier: A Biography (Toronto: McClelland and Stowart, 1976), 10; Gwyn, 179.

${ }_{75}^{75}$ Ibid., 178-179; 182.

${ }^{76}$ See: Jacques Monet, The Last Cannon Shot (Toronto: University of Toronto Press, 1969), 398.

${ }^{77}$ Confederation Debates, 59. 
this continent". ${ }^{78}$ Alongside the introduction of democracy in the United States had soon come "the introduction of universal suffrage" ${ }^{79}$ Now just under eighty years after the formation of the American republic and the first state's institution of manhood suffrage, what had occurred? For Cartier, the defects of republicanism had clearly revealed themselves: "governmental powers had become too extended...and mob rule had consequently supplanted legitimate authority; and we now saw the sad spectacle of a country torn by civil war, and brethren fighting against brethren." ${ }^{.80}$ Since unbridled democracy and universal manhood suffrage apparently led to civil war - indeed, one of the bloodiest civil wars in recorded history - Cartier concluded "that purely democratic institutions could not be conducive to the peace and prosperity of nations." ${ }^{.81}$ For the simple maintenance of order, Cartier believed that Canada should follow the British example and institute a restrictive, property-based franchise. As he himself worded it when addressing the Canadian Legislative Assembly, "un gouvernement fondé sur [le suffrage universel]...ne peut durer longtemps." ${ }^{82}$ For Cartier's fellow Conservative, the aforementioned Thomas D'Arcy McGee, the institution of democracy in Canada could end in an even worse result.

Speaking two days after Cartier, on February 9, 1865, McGee also viewed the United States as a political experiment gone horribly wrong. McGee himself had lived in the United States and had witnessed the persecution of his Irish brethren by the unfettered

${ }^{78}$ Ibid.

${ }^{79}$ Ibid. By "universal suffrage", Cartier means manhood suffrage. In Canada, during the midnineteenth century, the two terms were used interchangeably.

${ }^{80}$ Confederation Debates, 59. The American Civil War, which began in 1861 , split the nation into two: the northern Unionists and the southern Confederacy. Since the war was still well underway during the Confederation conferences and debates, it weighed heavily on the mind of the Confederation delegates.

${ }^{81}$ Ibid.

${ }^{82}$ Joseph Tassé, Discours de Sir Georges Cartier (Montreal: Eusèbe Senécal \& Fils, 1893), 269. 
temperament of the Yankee 'mob'. He believed that "[ $t$ ]he idea of a universal democracy in America is no more welcome to the minds of thoughtful men among us, than was that of a universal monarchy to the mind of the thoughtful men who followed the standard of the third William in Europe". ${ }^{83}$ If British North Americans should opt for universal democracy, McGee predicted a fate worse than the collapse of good government or the outbreak of civil war: he predicted the annexation of British North America by the United States. If the nations on either side of the forty-ninth parallel had similar political institutions, McGee foresaw an easy conquest: 'the Lower Provinces - the smaller fragments - will be 'gobbled up' first" and then the Canadas "afterwards by way of dessert". 84

To prevent such a horrible political result, McGee embraced the confederation scheme as proposed by Attorneys General Macdonald and Cartier. As he declared with rhetorical flourish to a chorus of cheers and applause, it "will enable us to bear up shoulder to shoulder; to resist the spread of universal democracy doctrine;... it will give us a new lease of existence under other and more favorable conditions; and resistance to this project, which is pregnant with so many advantages to us and our children, means ultimate union with the United States." ${ }^{\prime 85}$ The rejection of universal democracy and its associate, universal manhood suffrage, would therefore do more than to ensure peace and prosperity in the new Canadian nation: it would apparently also help guarantee that it would remain independent of the older American one and ensure that it would respect minority rights. As did Cartier, McGee also resisted an expansive franchise for the

\footnotetext{
${ }^{83}$ Confederation Debates, 143.

${ }^{84} \mathrm{Ibid}$.

${ }^{85} \mathrm{Ibid}$.
} 
pragmatic purpose of maintaining order. From this point of view, it thus appears that Canada's leading conservatives both drafted and endorsed the Confederation franchise to codify their own Burkean conservative values. That said, one must also remember that Canadians only called Macdonald, Cartier, and McGee 'Conservatives' for short: as politicians, they were technically members of the Liberal-Conservative party. While such a title may sound like a contradiction in terms, the opposition is not particularly apparent when it comes to nineteenth-century philosophies concerning the franchise.

Nineteenth-century liberal political thought approached the franchise from a different perspective than Burkean conservatism. While conservatives traditionally upheld a hierarchical arrangement of society where one's social position at birth dictates one's lot in life, liberals instead tended to believe in the perfectibility of humankind. Through one's own hard work and perseverance, one may rise in social rank and better one's lot in life. ${ }^{86}$ The same convictions held true with respect to the liberal view of the franchise. As one of the most liberal thinkers of the seventeenth century, the aforementioned French political theorist Montesquieu argued that "[a]11 inhabitants...ought to have a right of voting at the election of a representative, except such as are in so mean a situation as to be deemed to have no will of their own." ${ }^{\text {"87 }}$ Unlike

${ }^{86}$ According to Andrew Gamble in The Blackwell Encyclopedia of Sociology, liberalism, during the nineteenth-century, "came to signify adherence to the principles of individualism, liberty, limited government, progress, and equality." See: Andrew Gamble, "liberalism", The Blackwell Encyclopedia of Sociology, vol. VI, ed. George Ritzer (Malden, Mass.: Blackwell, 2007), 2622. In the Macmillan Encyclopedia of Sociology, Robert Boguslaw contrasts liberalism with conservatism. Whereas classical liberals favour "uniformity, egalitarianism, and pursuit of utilitarian goals", their conservative counterparts believe that "The only true equality is moral equality; civilized society requires orders and classes. Property and freedom are inseparable." See: Robert Boguslaw, "Liberalism/Conservatism", Encyclopedia of Sociology, vol. 3, $2^{\text {nd }}$ ed., eds. Edgar F. Borgatta and Rhonda J. V. Montgomery (New York: Macmillan Reference, 2000), 1598.

${ }^{87}$ Montesquieu, 155. By the phrase "all inhabitants", Montesquieu refers solely to men. While he may have held liberal views, he was not as radical as to suggest women should possess the franchise as equals to men. 
the conservative Burke, Montesquieu proposed a significant extension of the franchise: he felt that virtually all should have access to it. Like Burke, however, he also believed that the state should not permit all individuals to possess the franchise. The most impoverished classes of society, because of their dependence upon others through their reliance upon charity, apparently should remain the sole exception. ${ }^{88}$ Still, according to Montesquieu's argument, such a restriction would not be permanent. Through hard work and self-improvement, even the poorest of souls could climb out of penury and ensure themselves a better standard of living. In doing so, almost as a reward, they would receive the franchise.

By the time of Canada's Confederation, western liberal opinion concerning the franchise had changed little. In his 1861 treatise on representative government, the leading liberal political philosopher of the day, British Parliamentarian John Stuart Mill, extolled much the same point of view as Montesquieu. For Mill, "it is a personal injustice to withhold from any one...the ordinary privilege of having his voice reckoned in the disposal of affairs in which he has the same interest as other people."89 Just as lateeighteenth-century Americans demanded no taxation without representation, he argued

${ }^{88}$ This notion of indebtedness represented one of the strongest arguments in favour of a restricted franchise. Because indebted individuals relied on others to survive, they supposedly proved their inability to care for themselves and their families. If one could not care for oneself, one reportedly could not be expected to have the wherewithal to care for the nation through the franchise as well. Moreover, the reliance of debtors on debtees supposedly meant that debtees exercised substantial power over their debtors. Because of this power, those who favoured a restrictive franchise believed that debtees could coerce their debtors to vote in a particular way. Thus, debtees would supposedly have the unfair advantage of multiple votes because of the power they wielded. In the Canadian context, such arguments were employed to bar not only the poor from the vote, but also aboriginal Canadians. Since many aboriginal Canadians lived on government-established reserves and received government subsidies, it appeared to many legislators as if they relied on the government for their survival. As such, many Canadians argued that aboriginal enfranchisement would simply mean a slew of guaranteed votes for the government party. For an example of such an argument see the 1885 speeches of Liberal leader Edward Blake, and his compatriots: Canada, Official Report of the Debates of the House of Commons of the Dominion of Canada, $3^{\text {rd }}$ session, $5^{\text {th }}$ Parliament, vol. XVII (Ottawa: Maclean, Roger $\&$ Co., 1885), 1486ff.

${ }^{89} \mathrm{John}$ Stuart Mill, Considerations on Representative Government (Chicago: Gateway, 1962), 169. 
that if an individual "is required to implicitly obey, he should be legally entitled to be told what for; to have his consent asked, and his opinion counted at its worth, though not at more than its worth." $" 90$ Since all inhabitants of a country should apparently have access to the vote, Mill concluded that "[n]o arrangement of the suffrage, therefore, can be permanently satisfactory, in which any person or class is peremptorily excluded; in which the electoral privilege is not open to all persons of full age who desire to obtain it." 91 While such a statement contradicts Burkean political philosophy and its belief in an enduring limitation on enfranchisement, Mill still managed to inhabit considerable common ground with Burke.

Like Burke, Mill's opinions reveal that he too disfavoured the notion of universal manhood suffrage - that the state should bestow the franchise upon all citizens whether they wished to obtain it or not. He worried about the "danger of a low grade of intelligence in the representative body, and in the popular opinion which controls it; and danger of class legislation on the part of the numerical majority" should the state institute manhood suffrage. ${ }^{92}$ As such, he also advocated that legislators maintain certain restrictions on the franchise. As evidence of their intelligence and economy, he believed

${ }^{90}$ Ibid.

${ }^{91}$ Ibid., 170. Interestingly, and quite radically for the time, Mill favoured franchise expansion for both women and men alike. In true liberal (and paternalist) fashion, he wrote in Considerations on Representative Government: "In the preceding argument for universal, but graduated suffrage, I have taken no account of difference of sex. I consider it to be as entirely irrelevant to political rights, as difference in height, or in the colour of the hair. All human beings have the same interest in good government; the welfare of all is alike affected by it, and they have equal need of a voice in it to secure their share of its benefits. If there be any difference, women require it more than men, since, being physically weaker, they are more dependent on law and society for protection." See: Mill, 187. During the franchise reform debates in England of 1866 and 1867, Mill stayed true to his ideals and motioned an amendment "embodying the principle of female suffrage, which he said was a logical consequence of the constitutional maxim that taxation and representation should go hand in hand." See: "Suffrage for Women", Toronto Globe, 4 June $1867,1$.

${ }^{92}$ Mill, 139. 
that only literate taxpayers should receive the vote. ${ }^{93}$ In comparison with the propertybased franchise in England at the time (and those of the Canadian provinces), Mill set his desired suffrage qualifications quite low. In true liberal fashion, he reportedly did so to "leave the suffrage accessible to all who are in the normal condition of a human being". 94 Thus, the liberal Mill, much like Montesquieu, advocated a broad franchise that all could attain through hard work yet one that still contained restrictions limiting the vote to a select group of individuals. ${ }^{95}$

In light of Montesquieu's and Mill's arguments, and their partial affinity to those of Burke, many of the pronouncements made by the Liberal-Conservatives regarding the franchise can be seen to be rooted in liberal philosophy as much as that of conservatism. This holds especially true with regard to George-Étienne Cartier and Thomas D’Arcy McGee. As the Confederation Debates indicate, these two Liberal-Conservative politicians principally desired to defend the new Canadian nation against manhood suffrage to avoid disorder, anarchy, war, and, ultimately, annexation. Although Mill

\footnotetext{
${ }^{93}$ Ibid., 170-173.

${ }^{94}$ Ibid., 175. While Mill never defines what he precisely means by the "normal condition of a human being", one should assume that the phrase refers to self-sufficient individuals.

${ }^{95}$ While less influential than Mill, transplanted English liberal philosopher Goldwin Smith took a much greater interest in Canada than his fellow countryman. Like Mill, Smith throughout the 1860s advocated for a wider suffrage in England. As Mill also suggested, Smith believed that receipt of the franchise should depend upon some sort of educational test. Otherwise, the nation would receive a Parliament "elected by vast masses of gullibility, ignorance, and blind passion." Smith therefore did not advocate universal manhood suffrage either. See: Elisabeth Wallace, Goldwin Smith, Victorian Liberal (Toronto: University of Toronto Press, 1957), 145-148. With regard to Canada, it seems that Smith favoured an expanded franchise as well. In a column he penned for England's Macmillan Magazine, he argued: "And assuredly it is not on the ground of special certainty or stability that, in a colony like Canada, political distinctions in favour of real property ought to be drawn: for there are few places, we apprehend, where the value of land and houses is more uncertain and variable... But there seems to be a notion that because land itself is stable, property in it, though it may be the wildest of all possible speculations, is stable also: a mere illusion, as we need scarcely observe. The object, however, of this peculiar provision is no doubt to be explained simply by the desire of imitating the British constitution." To Smith, propertybased qualifications for the franchise made no sense for the new North American nation. In abolishing them, the franchise would have necessarily expanded. See: Goldwin Smith, "The Proposed Constitution for British North America", Macmillan's Magazine 11 (March 1865), 413. Three years after the publication of this letter, in 1868, Smith immigrated to Canada.
} 
(who, of course, did not live as a neighbour to the restless United States) did not foresee manhood suffrage as leading to as dire a consequence, he certainly viewed it as a danger that governments should explicitly avoid. Because conservative thinkers such as Burke cautioned his readers about the threat of manhood suffrage as well, Cartier's and McGee's positions would have broadly appealed to both conservatives and liberals alike. John A. Macdonald, on the other hand, adopted a more ideologically-defined position concerning the franchise question.

Although he also took a stand against manhood suffrage to prevent tyranny and maintain order (as both conservatives and liberals recommended), Macdonald made one assertion that his fellow Liberal-Conservatives did not make in 1865: that the franchise should guarantee the ascendency of property. Considering that conservatives such as Burke upheld property-ownership as the principal characteristic of political independence, Macdonald's emphasis on a property-based franchise was thoroughly conservative in its outlook. Moreover, the overall restrictiveness of resolution twenty-six as drafted by Macdonald lends itself better to Burke's conservative belief in maintaining as narrow an electorate as possible (considering that liberals such as Mill tended to endorse a more inclusive franchise legislation based upon intelligence or the payment of taxes). As such, it does appear, after all, that Macdonald drafted the inaugural Dominion franchise to coincide with his own conservative ideology. That said, one could still interpret such a restrictive franchise as reflecting elements of prevailing liberal ideology, albeit a more moderate version of it. Despite the essential restrictiveness of Canada's inaugural franchise, it did not disenfranchise anyone not already disenfranchised before Confederation, and it did not institute any new permanent exclusions from the vote. 
Indeed, nothing technically stopped those male Canadians with a willingness to work hard from saving their money and, eventually, purchasing enough land for their enfranchisement. Because of the general proximity of conservatism to liberalism when it came to the franchise, all Liberal-Conservatives, whether conservative or moderately liberal in their outlook, could have ideologically accepted resolution twenty-six. ${ }^{96}$ Yet, $_{\text {, }}$ the Liberal-Conservatives were not the sole party that occupied the Canadian Legislative Assembly. In fact, they shared the electorate's attention with a much more expressly liberal political group: the Reform Party.

At the time of Confederation, George Brown led the Reform cause. Owner of Canada's leading Liberal organ, the Toronto Globe, he had entered into a coalition government with John A. Macdonald's Conservatives in 1864 for the express purpose of forming the union. ${ }^{97}$ Deeply loyal to Great Britain himself, he also viewed Confederation as a way to draw Canada closer to the mother country. ${ }^{98}$ Such a view tied into Brown's liberal values. While he generally endorsed (and even praised) John Stuart Mill's philosophy, Brown was not nearly as radical as the British parliamentarian. ${ }^{99}$ As his biographer J. M. S. Careless has concluded, Brown upheld a more "moderate Victorian Liberalism", "believing in empirical, parliamentary growth, suspicious of doctrinaire

\footnotetext{
${ }^{96}$ In his recent Master's thesis, Carleton University historian David Banoub goes as far as to argue that moderate liberalism best describes George-Étienne Cartier's political ideology more than anything else. Because of Cartier's ideological ambiguity when it came to his discussion of the vote, this paper can neither support nor criticize Banoub's contention. While Banoub does make a passing reference to the franchise in his work, it concerns Montreal's La Minerve newspaper - reportedly one of Cartier's chief supporters - and not Cartier himself. See: David J. Banoub, "Liberalism, Quebec's Political Culture, and George-Étienne Cartier, 1864-1871", M.A. thesis (Carleton University, 2007), 72-73.

${ }^{97}$ Confederation Debates, 995.

${ }^{98}$ Ibid., 87; 91.

${ }^{99}$ Elsewhere, Brown's Globe heaped nothing but praise on John Stuart Mill. In a review of Mill's work in the English Parliament, the Globe gushed that "he has achieved an amount of success in the arena of actual politics, which his antecedents could scarcely have justified. He has shown himself to be no mere theoriser, but one who takes a practical statesmanlike view of matters of public interest..." See: "Stuart Mill on the New Order of Things", Toronto Globe, 13 August 1868, 2.
} 
remaking of the constitution. ${ }^{, 100}$ Indeed, he moderated his liberalism to such an extent that he reportedly viewed his newspaper as “'thoroughly conservative'; conservative, that is, by American standards."101 Brown consequently disagreed with Mill's encouragement of women's suffrage and viewed Goldwin Smith's argument that Canada should break away from the British Empire in a highly negative light. ${ }^{102}$

With regard to Canada's inaugural franchise, it is already known that Brown at least tacitly supported a restrictive franchise. As a Canadian delegate at the Quebec Conference, he had cast one of the votes that unanimously supported Macdonald's resolution for such a franchise. ${ }^{103}$ While Brown unfortunately said very little about the subject in the Confederation Debates, he at least briefly mentioned why he may have been led to such an endorsement. Like George-Étienne Cartier and D'Arcy McGee, Brown centres his explanation on a comparison with the United States. Speaking about congressional representation, Brown affirmed that "[i]f there is one evil in the American

${ }^{100}$ J. M. S. Careless, Brown of the Globe: Statesman of Confederation 1860-1880, vol. 2 (Toronto: Macmillan, 1963), 327. In fact, political scientists William Christian and Colin Campbell have argued that "The centrist, middle of the road position established by Brown and his supporters has remained a hallmark of the Liberal Party to this day." See: William Christian and Colin Campbell, Political Parties and Ideologies in Canada, $3^{\text {rd }}$ ed. (Toronto: McGraw-Hill Ryerson, 1990), 46.

${ }^{101}$ Christian and Campbell, 44. In comparison with political ideologies such as republicanism and universal democracy, Brown's moderate liberal ideology could appear as conservative.

${ }^{102}$ In his letter of October 1, 1864 to his wife Anne, Brown relates to her how he met Goldwin Smith at a party he attended. Rather disparagingly, Brown identifies Smith solely as "the Oxford Professor who seeks to cut off the colonies from Great Britain." See: Library and Archives Canada, George Brown fonds, MG 24-B40, "Textual records" series, volume 5, reel C1602, page 1056, letter from George Brown to Anne Brown, 1 October 1864.

${ }^{103}$ Considering the Reform cause generally upheld the ascendency of local (provincial) governments, one might think that Brown supported Macdonald's franchise resolution because it left control over the franchise in the hands of the provincial legislatures. At the Quebec Conference, however, Brown moved that "[a]s to Local Governments, we desire in Upper Canada that they should not be expensive, and should not take up political matters." Despite his Liberal roots, Brown consequently agreed with Attorney General Macdonald that the Dominion Parliament, once formed, should hold the preponderance of power. See: "Hewitt Bernard's Notes on the Quebec Conference, 11-25 October, 1864", in Documents on the Confederation of British North America, 113. According to J. M. S. Careless, Brown adopted this stance because he believed that provincial sphere would be less important in the new nation, that Upper Canada could best secure its interests in the Dominion Parliament, and that a centralization of power would avoid the problems encountered by the decentralized system of the United States (in other words, the Civil War). See: Careless, Brown of the Globe, vol. 2, 167-169. 
system which in my mind stands out as preëminently its greatest defect, except universal suffrage, it is that under than Constitution the representatives of the people must reside in the constituencies for which they sit." ${ }^{104}$ Although he may have only mentioned the franchise in passing, Brown still made his sentiments perfectly clear: that, above all else, universal manhood suffrage represents the worst institution established by the United States.

In the preceding years, Brown's newspaper, the Toronto Globe, illustrated why he viewed an expanded suffrage in such a negative light. As early as 1849 , Brown had editorially denounced the evils of universal suffrage, which he believed "had converted Republican France in to a neo-Napoleonic despotism..."105 Fourteen years later, when Nova Scotia repealed its manhood suffrage legislation in 1863 , the Globe's opinion had not changed whatsoever. It was more than happy to report that a system of property qualifications would return to restrict the vote in that province. As its editor wrote: "It is complained that under its [manhood suffrage's] influence men of intelligence, owners of property, are compelled to give way before ragged and penniless demagogues, who have nothing which should recommend them to the electors, unless glib tongues, great powers of buncombe, and illimitable impudence are fitting qualities in the legislators of a country."106 A restrictive franchise in Nova Scotia would apparently curtail this sort of demagoguery. With he and his paper set squarely against the institution of manhood suffrage for the sake of political order, Brown's arguments concerning the franchise fit just as well with Edmund Burke's conservatism as John Stuart Mill's liberalism (and the

${ }^{104}$ Ibid., 90.

${ }^{105}$ Sydney F. Wise, "Through the Lace Curtain: Canadian Views of American Democracy in the Pre-Civil War Period", Canadian Association for American Studies bulletin 2.2 (1967), 61. See also: "Influence of Liberty in Great Britain and the United States, No. III", Toronto Globe, 3 November 1849, 2. 106 "Manhood Suffrage in Nova Scotia", Toronto Globe, 13 April 1863, 2. 
views of Liberal-Conservatives for that matter). Aside from a somewhat enigmatic statement against universal democracy from Nova Scotian Liberal Adams George Archibald, no other Reform or otherwise expressly liberal member of the Canadian, Nova Scotian, or New Brunswick Legislative Assembly sought to follow Brown's example and address the franchise question. ${ }^{107}$ To determine whether Brown's sentiments reflected those of all British North American Liberals, or only his own, one must therefore turn to other sources.

As former Carleton University historian Sydney Wise has argued, "As the 1850s wore on, circumstances were to show that [Brown]...spoke for most reformers on the question of American institutions" such as universal manhood suffrage. ${ }^{108}$ Consequently, most Upper Canadian Liberals tended to agree with Brown's opinions on the subject as recorded in the Globe. The fact that the Globe also represented Canada's leading newspaper in terms of readership also speaks to the general acceptance received by

${ }^{107}$ During Nova Scotia's debates concerning Confederation, no one on either side of the floor, Conservative or Liberal, made any mention of the franchise at all. Their concerns rested with whether the union would benefit the province or not. Consequently, the debate revolved around topics such as whether representation by population would provide enough power to the province (considering its comparatively low population), and whether Nova Scotia would end paying more than its fair share. Liberal member of the Legislative Assembly and Confederation delegate Adams George Archibald offered perhaps the closest thing to an opinion on the franchise during these Nova Scotian debates. Referring to the United States' republican institutions, he remarked that "For however peaceably disposed the majority of the right thinking portion of the American people might be, everybody knew how difficult it was, in a country where the democratic element ruled, to control the impulses of the masses." While ambiguous, Archibald, like George Brown, was apparently sceptical of republican institutions (such as manhood suffrage). See: Nova Scotia, Debates and Proceedings of the House of Assembly, during the Second Session of the Twenty-Third Parliament of the Province of Nova Scotia 1865 [Hansard - Nova Scotia], $2^{\text {nd }}$ session, $23^{\text {rd }}$ Parliament (Halifax: Crosskill and Bourinot, 1865), 222. More generally, see: Ibid., 203-273. As far as this author could determine, members of New Brunswick's Legislative Assembly similarly made no comment with regard to the franchise resolution.

${ }^{108}$ Wise in Canadian Association for American Studies bulletin, 64. Indeed, Wise goes on to argue that while "Brown's Liberals and Macdonald's Conservatives might fight many a bitter political battle,... on the subject of American democracy both parties were in the same political culture." Wise unfortunately never specifies the exact political culture to which he refers. See: Ibid. 
Brown's brand of moderate liberalism. ${ }^{109}$ Outside of Upper Canada, however, other journals held sway amongst British North American Liberals. For example, on the east coast, the Novascotian and the Acadian Recorder represented two of the foremost Liberal newspapers of the day. Owned by Joseph Howe, the former Liberal premier of Nova Scotia, Halifax's Novascotian had become the province's leading newspaper as early as $1840 .^{110}$ While he was premier, Howe's Liberal government had repealed the colony's manhood suffrage legislation in $1863 .{ }^{111}$ As one might therefore expect, Howe's Novascotian held some particularly strong views concerning franchise law. A few months after the Confederation debates in the Province of Canada, the Novascotian published a long editorial on "The New Franchise Law". In the article, the editor declared that "We have had the trial of universal suffrage, and what was the result?...The penniless and ignorant servants and labourers of the well-to-do and intelligent merchant and farmer not only neutralize the votes of the latter, but by selecting their rules decide how much they shall be taxed and how they shall be governed. This is surely not right..."112 Joseph Howe's Novascotian therefore represented yet another British North American Liberal voice that vilified manhood suffrage. In accordance with both John A. Macdonald and George Brown, and Edmund Burke and John Stuart Mill, the absence of personal wealth should limit one's accessibility to the franchise. On this point, Nova Scotia's other leading Liberal newspaper tended to agree.

109 "[T]he most successful and profitable daily Journal in the Dominion" - indeed, its circulation doubled that of its next leading competitor, the liberal Montreal Witness - it had a wide distribution throughout western Ontario. See: Rutherford, $42 ; 49$.

${ }^{110}$ Howe purchased the Novascotian in late 1827. As Beck writes, it was the "best all-round paper in the province" and the "most influential newspaper in the province". See: J. Murray Beck, Joseph Howe: Conservative Reformer 1804-1848, vol. 1 (Montreal and Kingston: McGill-Queen's University Press, 1982), 41; 43; J. Murray Beck, "Howe, Joseph", Dictionary of Canadian Biography, vol. X, 363.

${ }_{111}$ Garner, 35.

112 "The New Franchise Law", Novascotian, 29 May 1865, 1. 
The Acadian Recorder was published out of Halifax. While not as popular as Howe's Novascotian, its presses ran for nearly the whole of the nineteenth century (and beyond). ${ }^{113}$ Aside from some "Radical tendencies", it generally remained loyal to the Liberal party throughout that time. ${ }^{114}$ When it came to "The Franchise Question", the Recorder adopted a perhaps broader, if no less scathing, view than that of the Novascotian. On March 24, 1865, it declared that "We are bound to say that any comparison between the character of Assemblies where a universal franchise is put against a limited franchise, whether as regards to the character of public men, insecurity of government, or corruption and profligacy in the management of public affairs, must tell strongly against universal suffrage." 115 For the Recorder's editor, the pages of history had spoken: those legislative bodies that had adopted manhood suffrage - whether in Nova Scotia, France, or the United States - had depreciated themselves and their abilities to govern.

In a statement that perhaps went beyond classical liberal ideology, the Recorder concluded its editorial by rather harshly stating that "[i]f possible it would be no unmitigated hardship to disenfranchise large numbers of worthy citizens if the worst class could be absolutely eliminated..."116 Once again, another Liberal newspaper stood quite categorically against any sort of widespread expansion of the suffrage. Moreover, the

${ }^{113}$ Mr. A. H. Holland published the Recorder from its inception in 1813 until his death 1830 . The Blackader brothers purchased it from Holland's brother six years later, and controlled the paper until its presses ran for the last time on May 10, 1930. See: Gertrude Tratt, "Holland, Anthony Henry", Dictionary of Canadian Biography, vol. VI, ed. Francess G. Halpenny (Toronto: University of Toronto Press, 1987), 321-323; Lois K. Kernaghan, "Blackadar, Hugh William", Dictionary of Canadian Biography, vol. IX, ed. Francess G. Halpenny (Toronto: University of Toronto Press, 1976), 54-55; J. Murray Beck, "Blackadar, Henry Dugwell", Dictionary of Canadian Biography, vol. XIII, ed. Ramsay Cook (Toronto: University of Toronto Press, 1994), 70-71.

${ }^{114}$ Rutherford, 235.

115 "The Franchise Question", Acadian Recorder, 24 March 1865, 2.

${ }^{116}$ Ibid. 
Recorder's editor felt so steadfastly opposed to manhood suffrage that he encroached upon conservative ideology in declaring it safest to disenfranchise too many citizens than too few. An otherwise Liberal newspaper, therefore, came closest to the conservative John A. Macdonald in unequivocally and unambiguously advocating the establishment of a Burkean franchise. While such a stance demonstrates the heavily moderated nature of liberal ideology in British North America, it also reveals the overlapping sentiment of contemporary conservative and liberal thought concerning the franchise. True, resolution twenty-six merely recycled the colonial franchises for the new Dominion franchise. In doing so, however, it also satisfied the adherents to British North America's two leading political ideologies: conservatism and classical liberalism. In fact, the Confederation franchise legislation snubbed only that small minority who had actually advocated the establishment of republicanism and manhood suffrage. Interestingly, some of these individuals - such as former Clear Grit William McDougall and Parti Rouge leader Antoine-Aimé Dorion - still occupied the benches of the Canadian Legislative Assembly. Both formed at the end of the 1840s, the Upper Canadian Clear Grits and the Lower Canadian Parti Rouge had broken away from classical liberal values as extolled by Montesquieu and Mill to espouse a more radical political ideology. While promoting elective political institutions, secularization, and a closer relationship with the United States (indeed, les Rouges even favoured annexation), they also advocated the establishment of universal manhood suffrage. ${ }^{117}$ During the 1850s, William McDougall - a journalist by profession, writing for the radical Toronto-based North American newspaper, and later a lawyer who practiced in Upper Canada - had positioned himself

${ }^{117}$ David Mills, "Clear Grits", The Canadian Encyclopedia, vol. III, $2^{\text {nd }}$ ed., ed. James H. Marsh (Edmonton: Hurtig, 1988), 1625; "Parti Rouge", The Canadian Encyclopedia, vol. I, 435. 
as one of the leading spokesmen of Clear Grit philosophy in Upper Canada. By 1862, however, he had joined sides with George Brown's Reformers; and, in 1864, he crossed the floor with his leader to take part in both the Macdonald-Brown coalition government as provincial secretary and the Confederation talks at Quebec. ${ }^{118}$ With the Clear Grit in him perhaps safely locked away by that point - or possibly scared away by the civil war raging in the United States - McDougall never once raised the question of the franchise during the Quebec Conference or the Confederation Debates. ${ }^{119}$ In fact, he hardly spoke at all. Instead, during the Confederation Debates at least, he centred his attention on his belief that the discussion had dragged on for too long and that all should be "determined to obtain as early as possible (without, however, preventing any honorable member from expressing his views upon them) a vote of this House." 120 As an ardent supporter of Confederation, he simply wanted it accomplished as quickly as possible. ${ }^{121}$ Dorion, on the other hand, did not exhibit quite the same inclination.

After assuming leadership of the Parti Rouge in 1854, Dorion had remained leader right through to Confederation. As such, he represented the chief FrenchCanadian Radical voice within the Canadian Legislative Assembly. Unlike William McDougall, Dorion and his Rouges neither joined the Macdonald-Brown alliance nor supported the Confederation project as designed in Quebec. ${ }^{122}$ Still, amongst his

\footnotetext{
${ }^{118}$ Suzanne Zeller, "McDougall, William", Dictionary of Canadian Biography, vol. XIII, ed. Ramsay Cook (Toronto: University of Toronto Press, 1994), 632-634.

${ }^{119}$ McDougall's nickname, 'Wandering Willie', was a rather caustic salute to this wandering allegiance.

${ }^{120}$ Confederation Debates, 719.

${ }^{121}$ According to Suzanne Zeller in the Dictionary of Canadian Biography, "During the confederation debates in 1865 [McDougall] expressed impatience with detailed discussion since the proposed escape from the legislative union of 1841 seemed to him both self-evident and inevitable." See: Zeller in Dictionary of Canadian Biography, 634.

122 Jean-Claude Soulard, "Dorion, Sir Antoine-Aimé", Dictionary of Canadian Biography, vol. XII, ed. Francess G. Halpenny (Toronto: University of Toronto Press, 1990), 263-264.
} 
harangues concerning the proposed union's unfair treatment of Lower Canada - from underrepresentation in the lower house to an overly centralized system of government he made no reference to the resolution concerning the Dominion franchise. ${ }^{123}$ His overarching statement that Cartier and Macdonald thought "that the hands of the Crown should be strengthened and the influence of the people, if possible, diminished" was the closest he came. ${ }^{124}$ Perhaps Dorion's belief in the ascendency of the local government led him to consider a provincially-controlled federal franchise as the best solution possible. If Lower Canadians desired manhood suffrage, they could then implement it for themselves. ${ }^{125}$ Even though the Confederation franchise explicitly discounted more radical liberal beliefs, those members of the Legislative Assembly most likely to protest such a rebuke made no concerted attempt to address the franchise question. So far, this analysis of Canada's inaugural franchise has focused predominantly on British North America's political institutions, and their arguments with regard to resolution twenty-six as agreed upon at Quebec. Of course, Canadians organized themselves in other ways as well. With that in mind, did the opinions of any other groups help sway their representatives to fashion the new Dominion franchise as they did?

Keeping in line with the general resistance directed toward universal democracy evinced across Canada in 1865 , the broad process behind Confederation was not a

${ }^{123}$ For a good snapshot of Dorion's arguments, see: Confederation Debates, 694.

${ }^{124}$ Confederation Debates, 255.

${ }^{125}$ In the Legislative Assembly, Dorion declared: "With these views on the question of representation, I pronounced in favor of Confederation of the two Provinces of Upper and Lower Canada, as the best means of protecting the varied interests of the two sections. But the Confederation I advocated was a real confederation, giving the largest powers to the local governments, and merely a delegated authority to the General Government - in that respect differing in toto from the one now proposed which gives all the powers to the Central Government, and reserves for the local governments the smallest possible amount of freedom of action." A provincially-governed franchise would have at least taken part in this supposed "smallest amount of freedom of action." See: Confederation Debates, 250. 
particularly democratic one. As previously mentioned, the thirty-two delegates at Quebec had agreed upon the seventy-two articles that would serve as the foundation for Canada's constitution. It then fell to the colonial legislatures of Canada, Nova Scotia, and New Brunswick to determine whether they agreed with those particular terms. In this all or nothing deal, the local governments therefore had no opportunity to alter the articles with which they may not have agreed. Moreover, in a universal democracy, something as monumental as the British North American union would have undoubtedly warranted an appeal to the populace itself. Whether by referendum or general election, the people would have the right in such a system to voice whether they actually wished to take part in the formation of a new nation. In the "pre-democratic" provinces of Canada and Nova Scotia, however, such a democratic measure was not an option. ${ }^{126}$ While members of the Canadian Legislative Assembly John Hillyard Cameron and Malcolm Crooks Cameron desired the approval of the people before the scheme's enactment, the House leaders firmly rejected the suggestion. ${ }^{127}$ For Conservative leader

${ }^{126}$ In his article on "The Canadian Political Elite's Attitudes Toward the Nature of the Plan of Union", Trent University historian Bruce W. Hodgins argues that "Confederation was basically the achievement of a pre-democratic elite at the very time when ideas of political democracy and concepts of local majoritarianism were growing, especially in Upper Canada." See: Bruce W. Hodgins, "The Canadian Political Elite's Attitudes Toward the Nature of the Plan of Union", in Federalism in Canada and Australia: The Early Years, eds. Bruce W. Hodgins, Don Wright, and W. H. Heick (Waterloo: Wilfrid Laurier University Press, 1978), 48.

${ }^{127}$ See: Confederation Debates, 962; 975. Conservative representative for Peel county in Upper Canada and a supporter of Confederation, John Hillyard Cameron upheld that the voters had not played a large enough role in the formation of the union. As he stated to the Legislative Assembly, he did not desire to "leave it for any one to say that the people had not had an opportunity of expressing themselves, through an election, on a matter of such vital importance - that I claim that it should be submitted to them, in order that they shall declare by their votes whether they are in favor of this measure or not." See: Ibid., 972. The Conservative representative for Ontario County north, Matthew Crooks Cameron, supported his colleague for a different reason. Not convinced by the Confederation scheme at all, he was "in favor of the resolutions going to the people in any way rather than the scheme should be carried out without such expression..." See: Ibid., 976. John Hillyard Cameron's motion ultimately failed by a margin of 84 to 35 . See: Ibid., 1020. For more on the two Camerons, see: Donald Swainson, "Cameron, John Hillyard", Dictionary of Canadian Biography, vol. X, 118-123; A. Margaret Evans, "Cameron, Sir Matthew Crooks", 
John A. Macdonald, such an appeal would be highly unconstitutional. As

"representatives of the people and not mere delegates", Macdonald believed that a referendum "would be robbing ourselves of the character of representatives". ${ }^{128}$ Indeed, for him, the direct appeal represented

the means by which a despot, at the point of the bayonet, may ask the people to vote yea or nay on the measure he proposes; but in every free country where there is a Constitution at all, the vote must be taken by the constituted authorities, the representatives of the people, and not become a mere form and cover to tyranny, but a measure which accords with the calm and deliberate judgments of the people, as expressed through their representatives. ${ }^{129}$

To uphold constitutional principles and to respect the decisions of voters made in the previous provincial election of 1864 , Macdonald steadfastly believed that it was his duty to reject any sort of democratic overture to the people with respect to the union. Reform leader George Brown, the long time "critic of American republicanism [and]... democracy", took the same position as Macdonald. ${ }^{130}$ He argued that "the verdict of the people [with regard to a potential referendum] may be judged from what has been the vote of their representatives here, who are responsible to them."131 Since the people had their chance to speak during the previous provincial election, Brown saw no need to ask their opinions once again. With the two party leaders in agreement that the people should have no direct say as to Confederation, Upper and Lower Canadians had to accept the scheme, and its resolution concerning the Dominion franchise, whether they liked it or not.

Dictionary of Canadian Biography, vol. XI, ed. Francess G. Halpenny (Toronto: University of Toronto Press, 1982), 143-146.

${ }^{128}$ Confederation Debates, 1004.

129 Ibid. Union", 48.

${ }^{130}$ Bruce W. Hodgins, “The Canadian Political Elite's Attitudes Toward the Nature of the Plan of ${ }^{131}$ Ibid., 992. 
Whereas the Province of Canada had its last general election before Confederation in 1864, Nova Scotia's took place in 1863 . Another election would therefore not take place in Nova Scotia until September of 1867, well after the Dominion's official formation. During this period, Nova Scotian Conservative leader Charles Tupper was the province's premier. A staunch believer in Confederation, he had the legislative muscle to back up his convictions: his party held forty of fifty-five seats. ${ }^{132}$ While Tupper may have worried more about the state of public opinion concerning the union than Macdonald, he took the same stance as his Canadian counterpart with respect to an appeal to the people. ${ }^{133} \mathrm{He}$ felt that Nova Scotia's participation in the union rested solely on "the decision of the Legislature." 134 The voters of Nova Scotia therefore had no direct way of affecting the Confederation scheme as supported by Tupper's majority government either. In fact, only in New Brunswick did the province's voters get the opportunity to pronounce their opinions concerning the union. In 1865, in the middle of the debates surrounding Confederation, the government's term expired and New Brunswick went to the polls. While New Brunswickers thoroughly rejected unionist premier Samuel Leonard Tilley's Conservatives for the anti-Confederation party of Liberal Albert James Smith, they could only vote on the overall mandate of the province. Like all other British North Americans, the people of New Brunswick had no viable way to directly revise the various articles of Confederation themselves. Soon after, in May of 1866, Smith's government, after a great deal of gubernatorial pressure, resigned; New

\footnotetext{
${ }^{132}$ Phillip Buckner, "Tupper, Sir Charles", Dictionary of Canadian Biography, vol. XIV, ed. Ramsay Cook (Toronto: University of Toronto Press, 1998), 1016.

${ }^{133}$ Hansard - Nova Scotia, $2^{\text {nd }}$ session, $23^{\text {rd }}$ Parliament, 215.

${ }^{134}$ Ibid.
} 
Brunswickers re-elected Tilley, and, in doing so, tacitly supported Confederation. ${ }^{135}$ Because of the generally undemocratic nature of Confederation, British North Americans had no real opportunity to effect a revision of the new Dominion's franchise should they have desired one. Even if they did have such influence, however, the large majority would have most likely seen no need to exercise it.

With leading members of the Clear Grits and the Parti Rouge having taken a large step away from their earlier demands for a radically-expanded franchise, these two of the largest potentially dissenting groups remained noticeably quiet concerning the restrictiveness of Canada's inaugural suffrage legislation. The general quiescence of other groups of Canadians also reflected their general tolerance of resolution twenty-six as determined at Quebec. Although the war-torn example of the United States may have frightened many into supporting a restrictive federal franchise, many had other reasons not to beat the drum against the franchise handed down by the Confederation delegates. Throughout the nineteenth century, farming represented the most common occupation in Canada. According to 1851 Canadian census figures, approximately thirty-seven percent of all workers (men women, and children) earned their living as farmers. Compare that to the next most popular occupation - that of 'labourer' - at approximately thirty-two percent. ${ }^{136}$ While nineteenth-century census figures tended to be unreliable in the consistency of their categorization, these data at least highlight in general terms the predominantly agricultural underpinnings of Canada's working population. By the 1871 1054-1055.

${ }^{135}$ C. M. Wallace, "Tilley, Sir Samuel Leonard", Dictionary of Canadian Biography, vol. XII,

${ }^{136}$ Canada, First Report of the Secretary of the Board of Registration and Statistics, on the Census of the Canadas, for 1851-52, vol. I (Quebec: John Lovell, 1853), 503-551. According to the census data, out of the 447,272 members of the work force in Upper and Lower Canada, 164,488 were identified as farmers. In comparison, 141,949 were identified as labourers. See: Ibid., 512; 515; 536; 539. 
census, the number of Canadians who earned their living through farming had increased to just shy of half of the working population (perhaps because this time farm labourers were apparently included under the category of 'farmer'). ${ }^{137}$ As Gail G. Campbell has argued in her study of the pre-Confederation franchise, farmers, of all groups of Canadians at the time, were most likely in British North America's developing society to own real property. Since they primordially relied upon the land for their livelihood, farmers "were more often prepared to make sacrifices" to acquire a piece of real estate. ${ }^{138}$ The franchise would have usually come with ownership of real property sizeable enough for farming. ${ }^{139}$ Because British North American farmers tended to possess enough property to ensure their enfranchisement - if simply for the sake of their livelihood - the majority of farmers would have generally had no reason to worry about the continuance of the restrictive provincial franchises in the federal sphere.

Of all the occupational classes in mid-nineteenth-century Canada, the Confederation delegates' choice of franchise would have adversely affected general labourers the most. After that of 'farmer', the category of 'labourer' represented the next most popular occupation in both the 1851 census and the 1871 census. ${ }^{140}$ As previously illustrated, these individuals would have been the least well paid and the least likely to possess real property of their own. One might therefore think that, of all Canadians,

${ }^{137}$ Canada, Census of Canada 1870-71, vol. III (Ottawa: I. B. Taylor, 1875), 250-345. In the 1871 census, 476,922 of 1,101,966 working Canadians were identified as farmers. This time, the census categorized only 124,922 Canadians as labourers. See: Ibid., 337; 339.

${ }^{138}$ Campbell in Canadian Historical Review, 176. The fact that arable land was still both relatively inexpensive and abundant in mid-nineteenth-century Canada also helped farmers in this respect.

${ }^{139}$ Because the franchise tended to go hand in hand with farming, Campbell relates that farmers encompassed a disproportionately large portion of the electorate. Through her case study of Albert County, New Brunswick during the 1840 s and 1850 s (an agricultural community at the time, mind you), she cites that while "Farmers comprised 56.6 per cent of the total workforce in Albert County, but 64.4 per cent of the total electorate. Of those who failed to qualify, just 26.7 per cent were farmers. See: Campbell in Canadian Historical Review, 176.

${ }^{140}$ See: Census of the Canadas 1851-52, vol. I, 515; 539; Census of Canada 1870-71, vol. III, 339. 
labourers would have had the greatest cause to actively promote an expanded franchise for the new Dominion. Several different factors combined to prevent them from doing so, however. True, as early as the $1850 \mathrm{~s}$, workingmen's associations began to emerge throughout urban British North America as industrialization brought large numbers of workers close together for the first time. While labourers had undoubtedly made advancements with respect to their organization, journalist and one-time New Democratic Party publican Steven Langdon reminds his readers that one "must not exaggerate the state of the state of central Canadian labour organization by the mid-sixties..."141 Indeed, Canadian labour historians agree that by Confederation in 1867 such workers still tended to concentrate their efforts solely within the local sphere and exclusively for specific groups of skilled craftsmen, such as coopers for example. ${ }^{142}$ Unskilled or general labourers were left to fend for themselves. ${ }^{143}$ Because of their very narrow focus, trade organizations of the period "remained small and vulnerable, even when they had formal links with central bodies of workingmen". ${ }^{144}$ Of course, it did not help that contemporary labour leaders tended to hold memberships within the existing political parties as well.

${ }^{141}$ Steven Langdon, The Emergence of the Canadian Working Class Movement 1845-1875 (Toronto: New Hogtown Press, 1975), 11. Langdon's article was originally published in two parts within the Journal of Canadian Studies. See: Steven Langdon, "The Emergence of the Canadian Working Class Movement 1845-1875", Journal of Canadian Studies 8.2 (1973), 3-11; Steven Langdon, "The Emergence of the Canadian Working Class Movement 1845-1875", Journal of Canadian Studies 8.3 (1973), 8-26.

${ }^{142}$ Bryan D. Palmer, "Labour Protest and Organization in Nineteenth-Century Canada, 18201890", Labour/Le Travail 20 (Fall 1987), 76; Eugene Forsey, Trade Unions in Canada 1812-1902 (Toronto: University of Toronto Press, 1982), 62; Bernard Ostry, "Conservatives, Liberals, and Labour in the 1870's", Canadian Historical Review 41.2 (June 1960), 93.

${ }^{143}$ Bryan D. Palmer, Working Class Experience: Rethinking the History of Canadian Labour 1800-1991, $2^{\text {nd }}$ ed. (Toronto: McClelland and Stewart, 1992), 89.

${ }^{144}$ Langdon, The Emergence of the Canadian Working Class Movement 1845-1875, 11. 
Because of such allegiances, party doctrine often came to overshadow labourers' grievances, particularly in an era of open voting. ${ }^{145}$

A strong labour press could have perhaps compensated for the fragmented and partisan nature of mid-1860s labour organization. By that time, however, British North America had only one weekly labour journal endorsed by the emerging labour movement: Hamilton's Workingman's Journal. Tellingly, it was founded and owned by Isaac Buchanan, Hamilton businessman and former Conservative Member of Canada's Legislative Assembly. ${ }^{146}$ While the Journal's first issue rolled off the presses in the spring of 1864 , it unfortunately "did not survive the events leading up to Confederation". Buchanan had gone bankrupt in 1866. When Confederation came into effect, Canada's labourers once again had no newspaper to call their own. ${ }^{147}$ Even the Palladium of Labor, Canada's premier nineteenth-century labour journal, had to admit in 1884 that at the time of Confederation, "The Labor press was weak and uninfluential - so far as Canada is concerned non-existent." ${ }^{\text {"148 }}$ Without such a journalistic voice, or centralized unions for that matter, Trent University historian Bryan Palmer has concluded that "[c]lass differences in these years definitely widened, but consciousness of such differentiation remained somewhat inhibited and constrained." ${ }^{149}$ Lacking this internal definition, cohesion, and direction, Canada's labouring classes had no way to concertedly

${ }^{145}$ Ostry in Canadian Historical Review, 127. Ostry argues that most labour leaders maintained party bonds right through the 1870 s and beyond.

${ }^{146}$ Verzuh, 11-15.

${ }^{147} \mathrm{Ibid} .$, 17. Canadian labourers would not receive another labour newspaper until 1872. In the spring of that year, the Ontario Workman published its first issue. See: Ibid., 19.

${ }^{148}$ Enjolras, "Progress", Palladium of Labor, 4 October 1884, 1.

${ }^{149}$ Bryan D. Palmer, Working Class Experience: Rethinking the History of Canadian Labour 1800-1991, 86. 
pressure their governments with regard to their enfranchisement, whether they desired it or not.

Women comprised the other most obvious group of British North Americans excluded from the Confederation franchise. While women had voted in Nova Scotian general elections and, more prominently, in Lower Canadian general elections, earlier in the nineteenth century, they had been effectively disenfranchised across British North America by the time Upper Canada and Lower Canada unified in $1840 .{ }^{150}$ Such events markedly contrast those in the United States, where by the end of that decade the women's suffrage movement had emerged as a political force under the leadership of Elizabeth Cady Stanton and Lucretia Mott. ${ }^{151}$ By the beginning of the 1860 s, prominent liberals in England such as John Stuart Mill had also begun to stir debate in favour of women's suffrage. ${ }^{152}$ Yet, such agitation had not spread to the perhaps more conservative British North American colonies. For most contemporary Canadian political commentators, women's enfranchisement was portrayed in an almost comical light. ${ }^{153}$ As later debates concerning Canadian women's enfranchisement would demonstrate, the majority of Canadians (including Canadian women, it seems) steadfastly upheld traditional, patriarchal divisions of labour that hived women within the household and protected them from the raucous political sphere. ${ }^{154}$ With open voting still in effect in all the provinces - where a voter would openly declare his choice of candidate on the

${ }^{150}$ Garner, 155-159.

${ }^{151}$ Keyssar, 173.

${ }^{152}$ See footnote 86 of this chapter.

${ }^{153}$ See, for example: "Suffrage for Women", Toronto Globe, 4 June 1867, 1.

${ }^{154}$ See: Canada, Official Report of the Debates of the House of Commons of the Dominion of Canada, $3^{\text {rd }}$ session, $5^{\text {th }}$ Parliament, vol. XVIII (Ottawa: Maclean, Roger \& Co., 1885), 1388-1442. As Carol Bacchi has somewhat controversially written, even those women who later took part in the Canadian women's suffrage movement during the last quarter of the nineteenth century upheld such views concerning divisions of labour. See: Bacchi, 146-149. 
hustings - enfranchised women would have had to brave the same foul language, threats, and scenes of violence endured by their fathers, brothers, sons, and husbands. Politics was a dirty business, a business evidently too dirty for the apparent delicacy of women. With such ideals so commonly upheld across Victorian British North America, no group of women or men actively sought to include women within the scope of the new Dominion franchise. Indeed, the first women's suffrage association would not arrive in Canada until 1876, almost an entire decade after Confederation. ${ }^{155}$ And even then, it would not achieve success until well into the twentieth century. ${ }^{156}$ Yet, British North Americans did not solely identify and organize themselves with regard to their political views, their occupations, and their gender. Linguistically-based cultural ties proved more powerful and cohesive in a society that Lord Durham had likened to two nations warring in the bosom of a single state.

Culturally, Canada has principally developed along the lines of its two founding European peoples: the English and the French. As mentioned earlier, English Canadian political culture at the time of Confederation tended to look toward Great Britain. Loyalty to British traditions and institutions served as a unifying bond. As John Garner has argued, "there were many [English-speaking] British North Americans whose attachment to the British constitution led them to silently support" the restrictive franchise, even if they did not fully understand the philosophies behind it. ${ }^{157}$ The citizens of French Canada were another story. Although many French Canadians, as Jacques Monet has argued, welcomed British political institutions as guarantors of their cultural

\footnotetext{
${ }^{155}$ Cleverdon, 20.

${ }^{156}$ Manitoba was the first province to enfranchise women for legislative elections. It did so in January of 1916. Canadian women could not vote federally until the following year. See: Ibid., 2.

${ }^{157}$ Garner, 6.
} 
self-preservation, they never forged the same instinctual bonds to the British Crown as their English-speaking countrymen. Theirs was an "Unemotional loyalty...; one founded not on sentiment, or quick-lived stirring passion." 158 After all, as Wilfrid Laurier would later phrase it in 1877, "nous Canadiens Français, nous sommes une race conquise. C'est une vérité triste à dire, mais enfin c'est las vérité."159 That being said, most French Canadians had still formed their own emotional bonds of loyalty. They simply did so with a different overseas authority: the Catholic Church.

Of those Canadians who identified themselves as deriving from French ancestry, contemporary census data indicates that the vast majority also identified themselves as Catholic. ${ }^{160}$ Still a traditionally conservative institution, the Catholic Church - both in Rome and in Quebec - had taken up the struggle against the spread of democracy. ${ }^{161}$ As historian Fernand Ouellet has written, "Dans la clergé, la représentation est aussi d'une exceptionnelle simplicité: les Etats-Unis sont assimiles à la France révolutionnaire, l'un et l'autre pays représentant par ses institutions une menace a la fois sociale et religieuse. La démocratie y apparait donc comme le véhicule infaillible de l'anarchie, du matérialisme, de l'incroyance et de l'athéisme."162 Because it apparently challenged both Church dogma and organized religion itself, the Pope, through the French Canadian

\footnotetext{
${ }^{158}$ Monet, 399. 1909), 85.

${ }^{159}$ Sir Wilfrid Laurier, Discours a L'Etranger et au Canada (Montreal: Librairie Beauchemin,

${ }^{160}$ The 1851-52 Canadian census identified 746,866 of 890,261 Lower Canadians as belonging to the "Church of Rome". That translates to approximately 84 percent of the entire Lower Canadian population. See: Census of the Canadas 1851-52, vol. I, 142. By the 1870-71 census, that percentage had increased $(1,019,850$ of $1,191,516$ or approximately 86 percent). In fact, by 1871 , Quebec alone contained over two-thirds of Canada's Catholic population. See: Census of Canada 1870-71, vol. I, 246-247.

${ }^{161}$ According to Church historian Joe Holland, the Catholic Church adopted a reactionary stance against the spread of democracy until the pontification of Leo XIII in 1878 (eleven years after Confederation). See: Joe Holland, Modern Catholic Social Teaching: The Popes Confront the Industrial Age 1740-1958 (New York and Mahwah, New Jersey: Paulist Press, 2003), 293-294.

${ }^{162}$ Fernand Ouellet, "Through the Lace Curtain: Canadian View of American Democracy in the Pre-Civil War Period: Commentary", Canadian Association for American Studies bulletin 2.2 (1967), 70.
} 
bishops, directed parish priests to speak out against the evils of democracy. ${ }^{163}$ While those French Canadians who relied on the United States for trade - such as French Canadian merchants, for instance - would have also recognized the economic prosperity that seemed to move hand-in-hand with American democracy, Ouellet relates that such views would generally not have trumped Catholic values (especially with the apparently failed example of American democracy so close at hand). ${ }^{164}$ Only portions of Lower Canada's liberal intellectual elite, as represented by the anti-Catholic Rouges, had actively endorsed democracy and manhood suffrage in French Canada; and, as previously mentioned, their leader, Antoine-Aimé Dorion, had remained noticeably silent on the subject at the time of Confederation. Although each group had different reasons for their positions, both English Canada and French Canada on the whole believed that a restrictive franchise best suited their collective beliefs. Without any particular group of British North Americans actively demanding different franchise legislation than that penned at Quebec, the Confederation delegates had nothing to stop them from instituting the type of franchise they desired for the new Dominion of Canada.

With the declaration of Confederation in July of 1867 , the franchise law decided upon at the Quebec Conference just under three years earlier finally came into effect.

${ }^{163}$ On December 8, 1864, Pope Pius IX disseminated an Encyclical Letter and Syllabus of Modern Errors to "our venerable brethren, all patriarchs, primates, archbishops, and bishops having the favor and communion of the Holy See" across the world, including Lower Canada. In the Encyclical, the Pope urges his flock to resist the "wicked men" who promise liberty by spreading "their fallacious opinions and most pernicious writings to subvert the formulations of the catholic religion and...civil society". Yet, the Pope saved his most direct attack against liberal democracy for the Syllabus of Errors. Consisting of eighty propositions, the ultimate proposition of the Syllabus specifically condemns liberal democracy. As it states, it is an error to believe that "[t]he Roman Pontiff can and ought to reconcile and harmonize himself with progress, with liberalism, and with modern civilization." If the Pope considered liberalism anathema, then the Catholic clergy in Lower Canada (and later Quebec) would have upheld and advocated the same view. See: Catholic Church, The Encyclical Letter of Pope Pius $L$, and the Syllabus of Modern Errors, Dated Dec. 8, 1864 (S.I.: s.n., 1864), 2; 15.

${ }^{164}$ Ibid. 
Instead of a freshly drawn piece of legislation, however, the new nation would simply employ the existing provincial franchises. Those Canadians who could legally vote in provincial elections could therefore legally vote in future federal elections as well. When attending the Quebec Conference, the delegates had very limited time to deliberate and fashion those principles that would form the institutional foundation for the new Dominion. For the sake of convenience, the Attorney General for Upper Canada, John A. Macdonald, suggested that the provincial franchises would suffice. If the delegates attempted to establish wholly new suffrage legislation that all could accept, the Quebec Conference may have stretched far longer that its eighteen-day duration, or broken apart altogether. Yet, those at Quebec would have never agreed to use the existing provincial franchises if they did not sit well with them ideologically.

The four provinces that originally joined together to create the Canadian nation Nova Scotia, New Brunswick, Quebec, and Ontario - all possessed rather restrictive, property-based franchises at the time of Confederation. For Liberal-Conservatives such as John A. Macdonald, George-Étienne Cartier, and Thomas D'Arcy McGee, Reformers such as George Brown, and other Liberals such as Nova Scotia's Joseph Howe, such limited franchises fit their ideological outlooks quite nicely. Not only did these franchises follow the precedent set by the mother country, Great Britain, they also appealed to both dominant British North American political ideologies: liberals and, even more so, conservatives. With restrictions placed on the provincial franchises, legislators felt assured that the real dangers - universal democracy and manhood suffrage - would not find their way into Canada any time soon. Living so close to the Civil War-torn United States, Canadian politicians had a clear view of the supposed effects of unbridled 
democracy and manhood suffrage on that nation. The Americans had chosen to rid themselves of British institutions and it had apparently torn their country in half: minority voices were suppressed, sectarianism was inflamed, and bloodshed was the result. Viewing the sad circumstances to the south, British North Americans, no matter their ideology, refused to make the same mistake. Although in the minority, even Clear Grits and members of the Parti Rouge such as William McDougall and Antoine-Aimé Dorion - individuals who had encouraged republicanism and manhood suffrage in the past voiced no concerted complaint with regard to the use of the restrictive provincial franchises for the Dominion franchise. Both Conservatives and Liberals in all the colonies therefore saw the Confederation franchise as a way to impose their parties' ideologies upon the new nation.

Outside the members of Canada's political parties, most other Canadians seemed to accept the restrictive, provincially-controlled franchise as well. Occupational, gendered, and cultural groups such as farmers, labourers, women, English-Canadians, and French-Canadians apparently did so because it either did not particularly affect them, it fit well into their shared set of cultural beliefs, or it did affect them adversely but they did not yet have the organizational capacity to lobby for and pursue any sort of change. And even if any of these groups had expressly coalesced to speak against the new Dominion franchise, the undemocratic nature of Confederation itself would have effectively muted their cries. Canada's first federal franchise was, therefore, bestowed from above by the nation's political elites. In choosing to employ the existing provincial franchises for the Dominion franchise, these elites fashioned legislation that largely served their own pragmatic and ideological interests. Despite Attorney General 
Macdonald's statement that Parliament would rewrite the nation's suffrage law as one of its first duties, the Confederation franchise remained on the statute books for the next eighteen years. It was left there to simmer for fear of upsetting the delicate balance of Confederation. Only in 1885 did Macdonald, who had since served fifteen years as prime minister, get around to delivering on his promise. 


\section{Chapter 3}

\section{"It is conservative in its very essence": The Electoral Franchise Act of $\mathbf{1 8 8 5}$}

On September 9, 1885, an exhausted Prime Minister John A. Macdonald settled down to catch up on his correspondence with Henry Molyneux Herbert, the fourth Earl of Carnarvon. A staunch conservative himself, Carnarvon was an old acquaintance of Macdonald - a kindred spirit, and a friend. ${ }^{1}$ In 1867 , as Secretary for the Colonies, Carnarvon both acted as one of the principal English advocates for colonial federation and, through his position, a confederated Canada by means of the British North America Act. $^{2}$ Earlier in 1885, however, Carnarvon had received a new position: the British government had appointed him Lord-lieutenant of Ireland. With the gruelling six-month Parliamentary session now over, as well as the multi-day sittings that accompanied it, Prime Minister Macdonald finally had the opportunity to offer Carnarvon his congratulations and best wishes with regard to the new post. While Macdonald expressed his disappointment that Carnarvon would no longer have the opportunity to assume the Governor Generalship of Canada - something that Macdonald earnestly desired, for he "looked upon [Carnarvon] as belonging especially to us" - Macdonald also articulated that he understood the challenge before his old friend: "taming" a land previously "untamed."

\footnotetext{
${ }^{1}$ Sir Arthur Hardinge, The Life of Henry Howard Molyneux Herbert Fourth Earl of Carnarvon 1831-1890, vol. 1, ed. Elisabeth Countess of Carnarvon (London: Oxford University Press, 1925), 82-83; Gwyn, 392.

${ }^{2}$ Hardinge, vol. 1, 327.

${ }^{3}$ Library and Archives Canada [LAC], Sir John A. Macdonald fonds, MG 26-A, "Political papers. Subject files" series, volume 526 part 2, reel C34, letterbook 23, page 280, letter from Sir John A. Macdonald to Lord Carnarvon, 9 September 1885.
} 
In the course of his letter to Carnarvon, Macdonald discussed the Dominion's recently legislated Electoral Franchise Act. As one of the primary parties responsible for Canada's constitution, Macdonald felt that Carnarvon would take an interest in any changes to it. ${ }^{4}$ Over two pages, Macdonald confided in Carnarvon the details of the struggle in which he had engaged to see his act passed. Most of Macdonald's criticism centred on the Liberal opposition, "or Grits as they are called", and how they continually and "violently" obstructed the passage of the act. ${ }^{5}$ In their apparently naked desire for power, Macdonald lamented that the Liberals had delayed necessary legislation and, in doing so, wasted both the Commons' and the nation's time. ${ }^{6}$ But, for Macdonald, the result was worth all the effort. Because of the new franchise act, his political dream had become a reality: the "Federal Constitution which [Carnarvon had] so great a hand in constructing...[had] at last been perfected."

Prime Minister Macdonald wrote these words to Lord Carnarvon over eighteen years after the ratification of the original British North America Act. During those years Canada came to embrace three other provinces - Manitoba in 1870, British Columbia in 1871, and Prince Edward Island in 1873 - and the whole of the Northwest Territories. With the partnership of these provinces and territories, the nation had spread itself from the Atlantic to the Pacific. Snaking its way across the country, the very recentlycompleted Canadian Pacific railway linked this vast tract of land together, technologically uniting it as one. Despite these grand accomplishments, Prime Minister Macdonald apparently did not feel he had completed his work with regard to the

\footnotetext{
${ }^{4}$ Ibid., 279.

${ }^{5}$ Ibid., 280.

${ }^{6}$ Ibid.

${ }^{7}$ Ibid.
} 
Canadian Confederation. Instead, it took the ratification of a franchise bill - a relatively short piece of legislation announced within the House of Commons five times before - to provide the 'Old Chieftain' with such a sense of accomplishment. ${ }^{8}$ Indeed, it was so important to him that he both drafted the legislation and tabled it himself. Macdonald's candidness with Carnarvon, therefore, generates multiple questions. First, why did Macdonald see the Conservative Franchise Act of 1885 as the "completion of the Federal Constitution" enacted almost two decades earlier? ${ }^{9}$ What legislative changes did it make to warrant such a response? What effects did it have, both on the federal franchise and on other aspects of governance? To its legislators, were any of these effects more important in comparison with the others? And, finally, was the act something that Canadians had generally demanded, or did it represent a personal project of Macdonald and his Conservatives? Through an analysis of the federal Franchise Act of 1885 and the debates surrounding it, this chapter will attempt to answer these questions. To begin, however, one must first understand what exactly this new legislation entailed.

When compared with Canada's previous franchise law, Prime Minister Macdonald's act represented a radical legislative departure. As mentioned in the preceding chapter, section 41 of the British North America Act stipulated that the provincial legislatures would operate the mechanisms of the suffrage until the Dominion Parliament dictated otherwise. It took eighteen years, but in 1885 Parliament finally spoke through its new act: the House of Commons would take full control over the federal franchise and its upkeep. The provincial governments would no longer have any official say as to the form Dominion franchise law would take. Alongside this

\footnotetext{
${ }^{8}$ Strong-Boag in Contesting Canadian Citizenship, 75.

${ }^{9}$ LAC, Sir John A. Macdonald to Lord Carnarvon, 279.
} 
administrative change, the new franchise act also completely retooled the qualifications for voting in federal elections. Since 1867 , the overall shape of the Dominion franchise had not remained constant. The provisions of section 41 ensured that Canada would have a variegated franchise. Over the span of these years, several provinces had seen fit to alter their provincial franchises. In doing so, they altered the federal franchise as well. While not all provinces followed the same pattern, these adjustments to franchise law generally resulted in much more inclusive franchise qualifications in comparison with those that existed at Confederation. ${ }^{10}$ For example, at the time of Confederation, Ontario imposed a $\$ 600$ property qualification on the enfranchisement of city dwellers, a $\$ 400$ qualification for town inhabitants, a $\$ 300$ qualification for those who lived in incorporated villages, and a $\$ 200$ qualification for township residents. In 1877 , however, it had reduced these property qualifications to $\$ 200$ for those who lived in cities and towns and $\$ 100$ for those who lived in incorporated villages and townships. ${ }^{11}$ Moreover, on April 24, 1885, as the federal Parliament debated the Electoral Franchise Act, Nova Scotia's legislature chose to pass "An Act to extend the Electoral Franchise". Through this legislation, Nova Scotia opened its franchise to certain inhabitants who did not own real property themselves: namely, the sons of property-owning men and widows. ${ }^{12}$ With his new Dominion franchise act, Prime Minister Macdonald apparently reversed this trend.

${ }^{10}$ Only Prince Edward Island had not altered its provincial franchise since Confederation. That said, Prince Edward Island's franchise was very inclusive to begin with. While Quebec did pass a new franchise law in 1875 , it did not lower its franchise qualifications. Urban residents still had to possess $\$ 300$ worth of real property, and rural residents $\$ 200$ worth of real property, to qualify for Quebec's provincial franchise. See: Thomas Hodgins, 179-205 (and 187-189 for Quebec's franchise in particular).

${ }^{11}$ Ontario, The Revised Statutes of Ontario, 1887, vol. I (Toronto: John Notman, 1887), 95.

${ }^{12}$ Nova Scotia, The Statutes of Nova Scotia, passed in the Forty-Eighth Year of the Reign of Her Majesty Queen Victoria, being the Third Session of the Twenty-Eighth General Assembly Convened in the said Province (Halifax: Commissioner of Public Works and Mines, Queen's Printer: 1885), 3-4. 
In forsaking seven disparate provincial franchises for a single, universallyapplicable piece of legislation, the Electoral Franchise Act of 1885 unified the Dominion franchise. Despite its replacement of these motley provincial acts, however, Canada's new suffrage law was arguably no easier to understand when it finally received its royal assent. Indeed, the Electoral Franchise Act contained so many different qualifications and exceptions that commentators have since attached to it a variety of unflattering descriptions, ranging from "a nightmare of complexity" to "an astonishing hodgepodge" to "a tangle of provisions verging on gibberish". ${ }^{13}$ While the basic conditions for enfranchisement had not changed - being a male British subject by birth or naturalization who had reached the age of majority of twenty-one - the other qualifications certainly had. To begin, Macdonald's act instituted a graduated property qualification depending upon the riding in which one lived. While residents of rural ridings only required $\$ 150$ worth of real property to vote, those who lived in towns required at least $\$ 200$ worth of real property. City-dwellers, on the other hand, had to possess $\$ 300$ in real estate. ${ }^{14}$ Under the same guidelines, male Canadians whose fathers owned enough real property to qualify them both also received the vote. Fishermen who did not meet the aforementioned property qualifications could also receive the franchise as long as they owned at least some real property and a minimum of $\$ 150$ in fishing equipment. ${ }^{15}$ No other occupations received the same courtesy.

If one did not own sufficient amounts of real property, all was not lost. Canadians could also qualify for the suffrage under the franchise act's tenant and income

${ }^{13}$ Forster, Davidson, and Brown, 20; Ward, 218; Elections Canada, 49.

${ }^{14}$ Thomas Hodgins, 64-67;82. See section 3 , subsection 3 for the property qualification for those Canadians who lived in cities or towns. See section 4 , subsection 3 for the property qualification for rural residents.

${ }^{15}$ Ibid., 90. See section 4, subsection 9. 
stipulations. In all ridings, potential voters who paid at least two dollars per month or twenty dollars per year in rent could also have their names placed on the voters' list. ${ }^{16}$ The same went for Canadians who earned at least $\$ 300$ per year in annual income. ${ }^{17}$ Since these tenant and income voters did not own property, however, they also fell subject to another requirement: they had to prove that they had lived in Canada for a minimum of one year before the date of the election. In addition to these qualifications, the franchise act provided special exemptions for residents of British Columbia and Prince Edward Island. ${ }^{18}$ Prime Minister Macdonald had conceded such special treatment because these two provinces had previously instituted significantly more liberal franchise laws than the others. ${ }^{19}$ As a result, residents of British Columbia and Prince Edward Island who had their names on voters' lists before the new act passed would retain their vote whether they met the new act's qualifications or not. Those who had not reached the age of majority by 1885 , however, were not so lucky. They would have to meet the same qualifications as the rest of country. ${ }^{20}$

If this patchwork of overlapping qualifications did not confuse revising barristers enough, the new franchise act also included stipulations based upon race. The act disenfranchised all persons who belonged to "the Mongolian or Chinese race" no matter how long they had resided in Canada. ${ }^{21}$ Such racist language followed closely an 1875

${ }^{16}$ Ibid., 73; 82; See: section 3 subsection 5 ; section 4, subsection 3 .

${ }^{17}$ Ibid., 76-78; 86. See: section 3, subsection 6; section 4, subsection 6 .

${ }^{18}$ Ibid., 102-105. See section 9.

${ }^{19}$ The provincial franchise of British Columbia contained no property qualifications whatsoever. Although Prince Edward Island's franchise did contain property qualifications, the Public Roads Act of 1879 permitted residents who did not own property to qualify for the franchise by performing "two days, or eighteen hours" of road work, or paying the equivalent in wages to the province. For British Columbia's franchise, see: Ibid., 198-200. For Prince Edward Island's franchise, including the Public Roads Act of 1879, see: Ibid., 201-205.

${ }^{20}$ Ibid., 102-105. See section 9.

${ }^{21}$ Ibid., 42-43. See section 2. 
amendment to British Columbia's franchise law that stipulated "No Chinaman...shall have his name placed on the register of voters for any electoral district, or be entitled to vote at any election of a member to serve in the Legislative Assembly of this Province. $\$ 22$ Aboriginal Canadians, on the other hand, received better treatment. Although British Columbia had also disenfranchised provincially every "Indian" within its borders, the new federal legislation made certain exceptions with regard to the new federal franchise. ${ }^{23}$ While British Columbian "Indians" would remain disenfranchised, as well as those who inhabited the Northwest Territories and Manitoba, the Electoral Franchise Act of 1885 gave the federal vote to the so-called "educated Indian": the male member of the First Nations who lived east of Manitoba and who owned a piece of real property that he had improved to a minimum value of $\$ 150 .^{24}$ This long series of qualifications encapsulated the Dominion franchise as it stood on January 1, 1886, when the new franchise act first took effect. To determine its overall effect upon the composition of the federal electorate, however, one must look beyond the legislation.

Within the generally-limited historiography of the Canadian federal franchise, scholars have disagreed as to the overall effect of the Electoral Franchise Act of 1885 on the size of the federal electorate. On the one hand, political scientists Norman Ward, Rod Preece, and Garth Stevenson have argued that despite Prime Minister Macdonald's supposed aversion to universal democracy, his legislation significantly increased the

\footnotetext{
${ }^{22}$ Ibid., 200. See "An Act relating to an Act to make Better Provision for the Qualification and Registration of Voters".

${ }^{23}$ Ibid.

${ }^{24}$ Canada, Official Report of the Debates of the House of Commons of the Dominion of Canada [Hansard], $3^{\text {rd }}$ session, $5^{\text {th }}$ Parliament, vol. XVIII (Ottawa: Maclean, Roger \& Co., 1885), 4 May 1885, 1576; Thomas Hodgins, 42; 109-111. See section 9c of the Act in particular.
} 
number of eligible federal voters. ${ }^{25}$ According to Ward - although he does not reveal the source of his statistics - the federal electorate as a whole grew by 27.7 percent between 1882 and $1891 .{ }^{26}$ Preece attributes an even larger expansion of the electorate to Macdonald's franchise act. Without revealing his sources as well, Preece concludes that "the final result was a franchise which, while being based on complex property qualifications, granted almost manhood suffrage. ${ }^{.27}$ In a later monograph, Stevenson adopts a similar view to that of Preece. Employing elections statistics compiled by former Dalhousie political scientist J. Murray Beck, he cites an apparent forty percent increase in votes cast between the federal elections of 1882 and $1887 .^{28}$ Of course, one could argue that the slow rise of national prosperity gradually lifted increasing numbers of eligible voters into the existing franchise. Because Canada's population and economic prosperity reportedly did not grow enough to adequately reflect such an increase, however, Stevenson concludes that "the measure was designed to exclude very few males from voting" and that by 1891 "universal male suffrage had been achieved in New Brunswick, Ontario, and Manitoba". ${ }^{29}$ The contentions upheld by Ward, Preece, and Stevenson lie in stark contrast to the latest work on the subject. In comparison with the studies of Ward, Preece, and Stevenson, A History of the Vote in Canada, an authoritative narrative review of the Canadian franchise

${ }^{25}$ Stevenson, 43. R. Kenneth Carty and W. Peter Ward also agree with the assessments of Stevenson and Norman Ward. According to them, "Without really intending to, it [the new electoral law] extended the privilege of voting somewhat, but this extension was limited and uneven..." While Kenneth Carty and Peter Ward do not provide any statistics to support their claim, they do cite Norman Ward's House of Commons: Representation. See: Carty and Ward in National Politics and Community in Canada, 71.

${ }^{26}$ Ward, 214; 221.

${ }^{27}$ Preece in Canadian Journal of Political Science, 473.

${ }^{28}$ Stevenson, 43.

${ }^{29}$ Ibid. 
commissioned by the Chief Electoral Officer of Canada, takes a completely different avenue of analysis to arrive at its judgement of the Electoral Franchise Act of 1885. As its author relates, complete election statistics do not exist for Canada's nineteenth-century Dominion elections. True, J. Murray Beck may have roughly determined the total number of votes cast on election day. ${ }^{30}$ Because the federal government did not keep precise electoral statistics, and because of the general unreliability of those they did keep, no one can know really how many individual Canadians actually had the right to vote at each election. It is therefore impossible to determine the extent to which exogenous factors such as population increase affected Dominion election returns. ${ }^{31}$ Moreover, as Ben Forster, Malcolm Davidson, and R. Craig Brown have argued, it is also impossible to determine how the complexity of Macdonald's act affected the size of the federal electorate. While these three authors admit that the number of federal votes cast may have increased after $1885,{ }^{32}$ they also hypothesize that the difficulty of interpreting the new act resulted in the erroneous provision of ballots to otherwise disenfranchised individuals. ${ }^{33}$ Indeed, these errors supposedly occurred on such a grand scale that Ontario recorded more votes cast in the 1891 Dominion election than adult men who lived in the province. ${ }^{34}$ As a result of such statistical impediments, Elections Canada's own interpretation of the vote in Canada instead turns to less problematic sources to arrive at its final position.

\footnotetext{
${ }^{30}$ For election statistics for the 1882 and 1887 federal elections, see: J. Murray Beck, Pendulum of Power (Scarborough: Prentice-Hall, 1968), 45; 56.

${ }^{31}$ Elections Canada, 50.

${ }^{32}$ Forster, Davidson, and Brown in Canadian Historical Review, 19.

${ }^{33}$ Ibid., 38.

${ }^{34}$ Ibid.
} 
To undertake its analysis, A History of the Vote in Canada juxtaposes the previously-used provincial franchises with the Electoral Franchise Act of 1885. According to such comparisons, the new act amplified the property qualifications for residents of Manitoba, Ontario, New Brunswick, and Nova Scotia by thirty-three to two hundred percent. Only in Quebec did this qualification decrease at all, and then only for rural ridings. ${ }^{35}$ Moreover, British Columbia and Prince Edward Island had both embraced near-manhood suffrage for their franchises well before 1885 . As a result, the author argues that any form of property qualification would have had to reduce the number of voters in each of these two provinces as well. ${ }^{36}$ By means of this information, A History of the Vote in Canada concludes that "In just one province - Quebec, a Conservative stronghold since 1867 - did the size of the electorate appear to have increased". 37

Upon weighing these two conflicting arguments, the latter proves more convincing. Without a doubt, J. Murray Beck's statistics, as employed by Stevenson in particular, indicate that Canadians apparently cast just over 207,000 more votes in the 1887 general election than in the 1882 general election. ${ }^{38}$ Yet, when one probes these statistics further, one finds some very strange inconsistencies with respect to Stevenson's contentions. Take Prince Edward Island, for example. According to Beck's figures, the number of votes cast in that province increased from 30,000 in 1882 to 36,000 in 1887 . At face value, it therefore appears that Prince Edward Island's electorate grew to such an extent that local returning officers could declare a twenty percent rise in ballots cast. But,

\footnotetext{
${ }^{35}$ Elections Canada, 50.

${ }^{36}$ Ibid.

${ }^{37}$ Ibid., 51.

${ }^{38}$ Beck, 45; 56.
} 
as previously highlighted, the new franchise act's institution of property and income qualifications undoubtedly restricted the federal vote in Prince Edward Island. When coupled with the fact that federal census returns indicate that the province's population apparently decreased between 1881 and 1891 , the reader cannot help but seriously question the statistical foundation upon which Stevenson's (and Ward's and Preece's) arguments rely.

The other half of Ward's, Preece's, and Stevenson's contention - that Prime Minister Macdonald designed his franchise act to disenfranchise as few male Canadians as possible - also loses much of its strength if one takes into consideration the Prime Minister's own correspondence. Four years after the legislation passed, Macdonald received a letter from one W. F. Roome, a Conservative stalwart and frequent correspondent hailing from Middlesex, Ontario. According to Roome, a large number of farm labourers in his constituency remained disenfranchised because they earned too little to qualify for the federal franchise. Since these labourers generally did not own real property, and that on average they received as pay " $\$ 159$ \& board or $\$ 250$ without board", Roome hoped that "the Franchise of wage earners be reduced from $\$ 300^{00}$ to

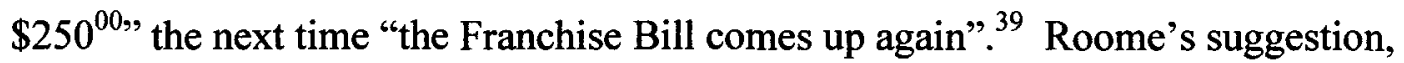
however, would have not only affected farm labourers. As indicated by the figures compiled within the Historical Statistics of Canada, most general labourers, lumbermen, and a good number of mill hands and textile workers would have also stood to benefit. ${ }^{40}$ Considering these occupations tended to pay just as poorly as farm labour when the

${ }^{39}$ LAC, Sir John A. Macdonald fonds, MG 26-A, "Political papers. Subject files" series, volume 472, reel C1796, page 234859, letter from W. F. Roome to Sir John A. Macdonald, 10 April 1889.

${ }^{40}$ Urquhart and Buckley, eds., 95. See also: Elections Canada, 56. 
franchise act passed in 1885 - and not only in Ontario, but across the country Macdonald's legislation would have consequently disenfranchised the vast majority of the men who undertook these largely unskilled occupations. ${ }^{41}$ While the ambiguity of nineteenth-century Canadian census returns does not allow an accurate determination of how many labouring men failed to meet the income thresholds of the federal franchise, the number was undoubtedly substantial. ${ }^{42}$ This study will thus adopt the argument that the Electoral Franchise Act of 1885 instituted a more restrictive franchise for Dominion elections when compared with the provincial legislation previously in place. As a result, the Prime Minister, in keeping with his Tory proclivities, halted the march toward federal manhood suffrage through his franchise act. Having established its position with regard to the Dominion Franchise Act, this chapter will now proceed to offer an explanation as

${ }^{41}$ According to the tables within the Historical Statistics of Canada, a Canadian farm labourer tended to make $\$ 1.00$ to 1.25 per day in 1885 . While a general labourer could earn up to $\$ 1.75$ or $\$ 2.00$ per day depending upon where he worked, the base salary for general labourers in Canada's urban centres remained at $\$ 1.00$ per day as well. Lumbermen, on the other hand, tended to receive their average $\$ 15$ to $\$ 20$ salary on a monthly basis. If a normal month contained twenty-six working days (based on the standard nineteenth-century six-day work week), then lumbermen brought in, on average, a very meagre fifty-eight to seventy-seven cents per day. See: Urquhart and Buckley, eds., 95.

${ }^{42}$ During the franchise debates in the House of Commons, Liberal member for Elgin County West, Ontario, George Elliott Casey, bandied about figures pertaining to the number of Canadians that the Electoral Franchise Act would disenfranchise. According to him, through his analysis of statistics he obtained through the Ontario Bureau of Industries, "it appears to be extremely probable that at least 125,000 persons will be disfranchised by this Bill" in Ontario alone. In other words, Casey believed that "about every fourth man who now possesses the vote will be deprived of it." Although he argued that "all the figures I have given are very moderate", Casey's estimate seems rather high (especially considering he used a $\$ 400$ Dominion income qualification to arrive at it). Still, if one adjusts the estimate to take into account a lower income qualification, one would imagine that it would still remain in the thousands. See: Hansard, vol. XVIII, 8 May 1885, 1742. Hamilton's Palladium of Labor newspaper also supported the view that the Conservatives' Electoral Franchise Act would have substantially reduced the size of the federal electorate. In the May 9, 1885 issue, in an article tellingly entitled "Assault on the Ballot Box", the Palladium's editor published the following pointed words: "From every point of view the franchise bill is an unjust, arbitrary and objectionable measure. It is unnecessary as there is nothing in the constitution requiring the basis of the franchise to be the same in all the Provinces. It is a retrograde step so far as Ontario is concerned, because the franchise as fixed last session by [Ontario premier] Mr. [Oliver] Mowat's act, is more liberal and comprehensive and includes a large class of voters, principally workingmen, who will be disfranchised should Sir John's bill carry." As Canada's premier workingman's advocate, the Palladium predicted that the new franchise act would have the same negative effect on Canada's working population as foreseen by George Elliott Casey. 
to why Canada received such legislation in 1885. To do so, John A. Macdonald's letter to Lord Carnarvon in September of that year offers a most revealing starting point.

Considering that Lord Carnarvon had endorsed Canada's original franchise as enshrined within Section 41 of the British North America Act, Prime Minister Macdonald felt that he had to justify to Carnarvon the changes that Canada's government made. Yet Macdonald made no mention of suffrage qualifications or electoral restrictions. He instead discussed how the Dominion franchise had been governed up to that point in Canadian history. As mentioned earlier, the provinces had overseen the federal franchise since Confederation. Because the provincial franchises in 1867 "did not greatly differ, [they] were allowed to continue". ${ }^{43}$ Macdonald revealed to Carnarvon that this balance had since changed. According to Macdonald, "the Provinces had begun to tinker at their electoral franchises" as part of their movement for provincial rights. ${ }^{44}$ Although these alterations had generally expanded the Dominion franchise, Macdonald did not centre his discussion on such details. On the contrary, his concerns lay with the fact that the provincial governments "in some cases legislated with the direct object of affecting the whims of the Federal Parliament, so that the dependence of that Parliament was threatened to such a degree that it had to be dealt with., ${ }^{, 45}$ As such, Macdonald apparently viewed complete federal control over the Dominion franchise as perhaps the

${ }^{43}$ LAC, Sir John A. Macdonald to Lord Carnarvon, 2.

${ }^{44}$ Ibid. By the early 1880 s, the provinces had begun their wider assault on federal prerogatives. Dissatisfied with "the cavalier treatment they were wont to receive from Ottawa", as historian Peter Waite so elegantly worded it, they had "begun to think of their own individual identity" and of how they too should have a say in the direction of the country. Thus began a series of interventions where the provinces sought to wrestle power from the federal government. The provinces choice to "tinker" with their franchises would have played in a part in this overall provincial desire for increased influence. For more on the provincial rights movement, see: P. B. Waite, Canada 1874-1896: Arduous Destiny (Toronto and Montreal: McClelland and Stewart, 1971), 75-77.

${ }^{45}$ LAC, Sir John A. Macdonald to Lord Carnarvon, 2. 
most important goal of his party's legislation. Indeed, when the House of Commons had debated the franchise act, the Conservatives repeatedly hammered at this point. ${ }^{46}$ As Macdonald's Secretary of State Adolphe Chapleau rhetorically put it: "Is it worthy of our Parliament, is it according to the dignity which this Parliament owes to itself, to allow the smallest Legislature of the smallest Province, not only to dictate, but to change, at its will, at its own caprice, the electoral franchise by which the members of the House of Commons are elected?"47 Macdonald himself insinuated that both the legislatures of Ontario and Nova Scotia had forwarded new franchise legislation that militated against the Dominion's best interests. ${ }^{48}$ In his letter to Carnarvon, Macdonald therefore made it appear that the Dominion government needed to take full control over the federal franchise, and consequently alter existing franchise law, for the sake of asserting effective federal sovereignty over the young Dominion. Without Parliamentary intervention, the Dominion would apparently fall under the legislative thumb of the provincial premiers and their own, more local ambitions. As a strong believer in centralized government himself, Carnarvon would have most likely approved of such a measure. ${ }^{49}$ Carnarvon

\footnotetext{
${ }^{46}$ For example, on April 21, 1885, Conservative Member of Parliament for King's County, Nova Scotia Douglas B. Woodworth argued: "Thus our Local Legislatures step in and disfranchise a number of electors at their own will and fancy, while this House lies powerless at their feet. This will continue until this House takes action, and it is provided by our constitution that at some time this should be done." See: Hansard, vol. XVIII , 21 April 1885, 1231.

${ }^{47}$ Hansard, vol. XVIII, 17 April $1885,1174$.

${ }^{48}$ In Macdonald's own words: "We have had an Act passed in the Legislature of Ontario; there is an Act now before the Legislature of Nova Scotia; there may be Acts passed in every Province in the Confederation, and these Acts may sweep away half the constituency which centre here or may enlarge the constituency much further than for Dominion purposes, on Dominion principles and with Dominion responsibilities, it ought to be extended." See: Hansard, vol. XVIII, 16 April 1885, 1133.

${ }^{49}$ On February 19, 1867, Carnarvon explained the British North American Confederation scheme and its division of powers to the House of Lords. When it came to the fact that the most important areas of governance, such as the enactment of criminal law, resided within the domain of the central government, he felt that he could not "but note a wise departure from the system pursued in the United States, where each State is competent to deal as it may please... The system here proposed is, I believe, a better and safer one..." See: Hardinge, 310.
} 
welcomed Macdonald's letter wholeheartedly at any rate. ${ }^{50}$ Yet, the primacy of the central government did not represent the sole reason behind Macdonald's desire to centralize Canada's federal franchise. Tellingly, the Prime Minister did not reveal to Carnarvon his other, more cunning motivation.

While the Conservatives often altruistically touted their franchise legislation as being in the best interests of the nation, they failed to mention the benefits it would confer on those holding the reins of power: in this case, the Conservative party itself. While Prime Minister Macdonald had pointed out that the provincial governments had instituted new legislation that did not coincide with the Dominion's interests as a whole, his Quebec lieutenant Hector Langevin had a slightly different take on provincial tampering with the franchise. ${ }^{51}$ In the House of Commons, he openly complained that "one of the smaller Provinces of this Dominion...for the purpose of depriving a certain number of people of the right to vote, men who were known to be disposed to vote for the Conservative party, it passed an Act to erase their names from the assessment book, and therefore from the list of voters." ${ }^{, 52}$ Unfortunately, Langevin never named the province in

${ }^{50}$ According to Carnarvon, in his letter to Macdonald dated October 1, 1885, "The sight of your handwriting was very welcome to me, and...your good wishes on the difficult \& doubtful task in at which I am engaged now." See: LAC, Sir John A. Macdonald fonds, MG 26-A, "Political papers. Subject files" series, volume 420, reel C1773, page 203702, letter from Lord Carnarvon to Sir John A. Macdonald, 1 October 1885.

${ }^{51}$ A lawyer by training, Sir Hector-Louis Langevin entered the Canadian Legislature in 1857. After George-Etienne Cartier's death in 1873, he took over the Quebec wing of the Conservative party. While Langevin held the position of John A. Macdonald's Quebec lieutenant throughout the $1880 \mathrm{~s}$, he effectively ended his political career in 1892 under the dark cloud of the McGreevy affair (by which one of Langevin's close friends and roommates, Thomas McGreevy, a Conservative Member of Parliament himself, had underhandedly awarded government building contracts to his brother, Robert McGreevy). See: Andrée Désilets, "Langevin, Sir Hector-Louis", Dictionary of Canadian Biography, vol. XIII, 567572.

${ }^{52}$ Ibid., 1138. 
question. ${ }^{53}$ Still, if he was correct in his accusation, at least one provincial government had passed legislation intending to affect the outcome of a Dominion election and, in this case, remove the Conservative government from power.

Although Langevin made sure to highlight the fact that his party "desire[d] to pass [the] law to protect the voters against any similar action on the part of the Local Legislatures", it seems that the federal Conservatives had more to protect than the sanctity of Canada's general elections from provincial plying. ${ }^{54}$ They also moved to protect their own political fortunes. The Conservatives had telegraphed their partisan manoeuvre to such an extent that the Opposition easily picked up on it. As William Vail, Liberal member for Digby, Nova Scotia, announced: "I do not know what the object the Government have in view in introducing this Bill. I can only imagine that it was to strengthen themselves, and I am really disposed to think that it was because of the fight that has been going on between the Local Government of Ontario and the Dominion Government for the last half a dozen years." $\$ 5$ Ontario's premier, Oliver Mowat, had positioned himself as Prime Minister Macdonald's greatest adversary in the struggle for

${ }^{53}$ During the Commons debate over the Liberal Franchise Act in 1898, then Conservative leader Sir Charles Tupper mentioned "that in the province of Nova Scotia the legislature absolutely passed a franchise Act after the general election to have an effect upon the Dominion elections, although they never intended to use it and never did use it, for their own elections; and they repealed the Act before the local election came on, showing they had absolutely the power to control the representation of this Parliament..." While Tupper never provided the year Nova Scotia passed or repealed this legislation, it may be the instance to which Langevin refers. See: Hansard, $3^{\text {rd }}$ session, $8^{\text {th }}$ Parliament, vol. XLVI (Ottawa: S. E. Dawson, 1898), 22 March 1898, 2274.

${ }^{54}$ Hansard, vol. XVIII, 16 April 1885, 1138.

${ }^{55}$ Hansard, vol. XVIII, 21 April 1885, 1276. The Honourable William Berrian Vail was Minister of Militia from 1874 to 1877 in Prime Minister Alexander Mackenzie's short-lived Liberal government. According to Stephen J. Harris in the Dictionary of Canadian Biography, Vail spoke rarely when in opposition, and then only briefly. Harris's assessment proves accurate with regard to the franchise debates in 1885 as well. See: Stephen J. Harris, "Vail, William Berrian," Dictionary of Canadian Biography, vol. XIII, ed. Ramsay Cook (Toronto: University of Toronto Press, 1994), 1045-1046. 
provincial rights. ${ }^{56}$ By federalizing the Dominion franchise through his legislation, Macdonald placed more power in his government's hands at the expense of provinces such as Ontario, and men such as Mowat. By means of the partisan exercise of this power, he could better protect his party from any provincial attempts to help diminish the power of the Conservatives or remove them as the government party (at least in the short term). ${ }^{57}$ This sort of pragmatic partisanship found its way into other aspects of Macdonald's franchise reform as well.

As the party that took the lead in promoting provincial rights, the opposition Liberals were not particularly happy with Prime Minister Macdonald's decision to remove control over the federal franchise from the provincial realm. According to Liberal leader and constitutional legalist Edward Blake, in perhaps the longest speech of the session, such centralizing tactics went against the federal principle upon which the Dominion was founded. ${ }^{58}$ Because the provincial legislatures better represented "public opinion" in Canada, Blake argued that "it is the people of the Province... who should tell you in what shape your representation is to take place." ${ }^{59}$ While the Conservatives' decision to ignore provincial opinions contradicted the core Liberal value of political

\footnotetext{
${ }^{56}$ One of Macdonald's former schoolmates, and an apprentice at Macdonald's Kingston law firm, Oliver Mowat became, according to Richard Gwyn, "Macdonald's most relentless and effective political opponent as premier of Ontario." Throughout the $1880 \mathrm{~s}$, Mowat fought to protect the provincial rights conferred by section 92 of the British North America Act from the centralizing tendencies of Macdonald's federal government. Confident that the British North America Act conferred provincial sovereignty, Mowat battled centralizing legislation in court, oftentimes travelling to defend provincial rights in person at the Judicial Committee of the Privy Council. According to historical writer Paul Romney, Mowat's "finest hour" and "greatest victory" took place in 1884 - the year before the Electoral Franchise Act became law when he successfully protected Ontario's borders from federal tampering. See: Gwyn, 48; Paul Romney, "Mowat, Sir Oliver," Dictionary of Canadian Biography, vol. XIII, 734-736.

${ }^{57}$ Of course, the federal Conservative party would not have to worry about provincial spite as much when the provinces returned Conservative legislatures of their own.

${ }^{58}$ Hansard, vol. XVIII, 17 April 1885, 1182. In Hansard, the speech spans sixteen pages. Considering the day's nine and a half hour session (three o'clock in the afternoon to one thirty in the morning, minus one hour at six o'clock in the evening for recess) spans thirty-eight pages, Blake's speech stretched on for approximately four hours.

${ }^{59} \mathrm{Ibid}$.
} 
pluralism, members of the Liberal party such as Blake did not see it as the worst outcome of a federally-controlled Dominion franchise. Instead, Liberals denounced most heavily the fact that federally-governed franchise legislation would directly result in the federal government's control over who voted in Canada's general elections.

Since Confederation, several responsibilities came with jurisdiction over the federal franchise. Of these responsibilities, the creation of the federal voters' lists represented the most important. Through the names on these lists, returning officers would determine who could vote and who could not vote in a given constituency. Until January 1,1886 , this task fell to the various provinces. Since the provincial legislatures had to produce voters' lists for their own general elections as well, this legislative understanding effectively (and economically) killed two birds with one stone: since the Dominion used provincial election law for federal elections, the provincial voters' lists would double as federal lists. Of course, Prime Minister Macdonald's legislation changed this arrangement. With the Dominion franchise differing from the provincial franchises, it now became the Dominion government's responsibility to fashion new, separate voters' lists for its own general elections. According to the government's Liberal opposition, such a stipulation allowed Macdonald's Conservatives to pursue all sorts of political chicanery.

Whether at the provincial or federal level, the task of drawing up voters' lists fell to the revising barrister, also known as the revising officer. Normally (but not necessarily) a judge who presided in the riding for which he would create the list, these officers had final say as to whose name would appear on the final register. Without a governing body such as Elections Canada to preside over general elections, the 
government of the day had the duty of appointing its revising barristers. Because the Electoral Franchise Act of 1885 centralized control over the Dominion franchise, the Prime Minister consequently became the person most directly responsible for making such appointments, thereby placing himself in a position to reap a political harvest from them. Conveniently, the Prime Minister in this case was the same person who drew up the franchise act. Such an arrangement placed new privileges and powers at the Prime Minister's fingertips. Because each electoral district required its own revising barrister, the new franchise legislation created 215 prime patronage positions ${ }^{60}$ for the Prime Minister to distribute amongst those who he wished to reward. ${ }^{61}$ It was this new role for the government that irked the opposition Liberals so much.

For the Liberals, the revising barrister clause of the new franchise act represented Prime Minister Macdonald's attempt at rigging federal elections in favour of his Conservative party while at the same time flattering his ideals for centralized authority in the new Dominion. ${ }^{62}$ While Macdonald agreed after much protest that revising barristers should primarily come from the ranks of Canada's sitting judiciary - although "a barrister of at least five years' standing at the bar" would also suffice - the clause did not receive any other sort of qualifications. ${ }^{63}$ The legislation therefore allowed Prime Minister

${ }^{60}$ The number of revising barristers required would of course change as Parliament created new electoral districts. For example, in the federal election of 1882, Canadians elected 211 Members of Parliament. By the 1887 federal election, however, Parliament had seen fit to provide the Northwest Territories with four seats of its own, thus raising the number of total seats (and electoral districts) to 215 . See: Beck, Pendulum of Power, 45; 56.

${ }^{61}$ The fact that Prime Minister Macdonald filed over 650 pieces of correspondence concerning the position of revising barrister and its appointment reveals its importance as a patronage position.

${ }^{62}$ Thomas Hodgins, 112-113. See sections 13 and 14.

${ }^{63}$ On May 28, Prime Minister Macdonald submitted that the revising barrister clause should read: "Any revising officer to be appointed under this Act shall, in any Province except Quebec and British Columbia be either a judge or junior judge of any County or District Court in the Province in which he is to act, or a barrister of at least five years standing at the bar of such a Province. In the Province of Quebec he shall be either a judge of the Superior Court of Lower Canada or an advocate or notary of the Province of at 
Macdonald to select judges loyal to the Conservative cause if he so chose. Indeed, the aforementioned revising barrister for East York, Judge Edward Morgan, apparently represented such a partisan appointment. As Alfred Boultbee, that loyal Conservative lawyer from Toronto, revealed to Macdonald, Morgan "is one of not a few in this country whose politics seem to begin \& end in you [i.e. Macdonald]." ${ }^{64}$ The Liberals feared that, with Conservatives revising the nation's voters' lists, the revising barristers might find ground to allow normally-disenfranchised Conservative sympathizers the vote and to keep the names of known Liberal supporters off the ledgers. As Liberal Member of Parliament for Peel County, Ontario, James Fleming argued on the very first day of debate over Macdonald's franchise act: "Now, we are to have the revising officers appointed by the Government on the recommendation of hon. members supporting the Government in this House. I will venture to say that they will recommend, and that the Government will appoint on their recommendation, the revising officers for the purpose of making the voters' list in the interest of those who nominated them." ${ }^{.65}$ If Fleming's hypothesis proved correct, the revising barrister clause in the new franchise act would allow Prime Minister Macdonald to indirectly fashion the nation's voters' lists for his own partisan purposes.

least five years' standing." Similar wording found its way into the final act as well. See: Hansard, vol. XIX, 28 May 1885, 2172. See also: Thomas Hodgins, 113 (section 14).

${ }^{64}$ Considering the language Boultbee employs in his letter, it seems that he and Morgan were friends. Not only did Boultbee view Morgan as a "clever fellow", Morgan had specifically asked Boultbee "to convey his gratitude to you for the appt. [to the position of revising barrister]..." The fact that Boultbee represented the Conservative cause in Morgan's court of revision for East York speaks volumes to the profundity of the partisanship permitted by the Electoral Franchise Act's revising barrister clause. See: LAC, Sir John A. Macdonald fonds, MG 26-A, "Political papers. Subject files" series, volume 11, reel C1491, page 3854, letter from Alfred Boultbee to Sir John A. Macdonald, 17 September 1885.

${ }^{65}$ Hansard, vol. XIX, 16 April 1885, 1148. 
Fleming was not alone in highlighting this particularly partisan aspect of

Macdonald's legislation. Every Liberal who spoke before the House of Commons during the franchise debates in 1885 in some way scolded the Conservatives for such a blatant attempt "to grasp the ballot box" for partisan purposes. ${ }^{66}$ The attacks ranged from Louis Henry Davies's reference to revising officers as "voter makers" to James Frederick Lister's statement that as "infamous as the Gerrymander Act was, this is infinitely more so."67 So enraged with the blatant partisanship on the Prime Minister's part, certain Liberal Members of Parliament went as far as advancing statements that would have bordered on slander outside the House. For example, in one particularly vitriolic tirade directed against the Prime Minister, Liberal member for Huron West, Malcolm Colin Cameron, exclaimed: "I am satisfied that if the hon. gentleman had invoked the powers below, if he had invoked his Satanic Majesty to prepare a Bill that would enable the hon. gentleman to remain in place and power for years to come, he could not have succeeded

${ }^{66}$ Liberal Member of Parliament for Lambton East, Mr. J. H. Fairbank, employed these words. See: Ibid., 21 April 1885, 1227.

${ }^{67}$ Ibid., 16 April 1885, 1150; 1156 . In the 1882 Parliamentary session, Prime Minister Macdonald's Conservatives introduced its Redistribution Bill before the House of Commons. It proposed to redraw the size and shape of Canada's federal constituencies. As Dalhousie University historian Peter Waite has explained, "Redistribution could have been done by committee with some semblance of honesty. Instead it was an unblushing attempt to weaken the Liberals by engineering out of existence wherever possible some of their electoral support." In a process known as gerrymandering (hence the nickname for the legislation), the Redistribution Bill rearranged closely contested electoral districts that returned Liberal Members of Parliament in such a way that the new districts would most likely elect Conservatives as well (for example, a Liberal constituency could be divided into two so that the Conservatives could capture at least one of the seats). Prime Minister Macdonald therefore designed the Gerrymander Act of 1882 to ensure Conservative ascendency over the Liberals. The similarity between it and the revising barrister clause in the Franchise Act of 1885 is admittedly uncanny. See: Waite, Canada 1874-1896, 114. The term gerrymander itself derives from the name of the eighteenth and early nineteenth-century American republican politician Elbridge Gerry. A signer of both the Declaration of Independence and the Articles of Confederation, Gerry was inaugurated as governor of Massachusetts on June 13, 1810. As governor, Gerry's administration passed legislation in February of 1812 that divided the state's senatorial districts along highly partisan lines. Moreover, Gerry's home county of Essex had been redrawn in such a way that Gerry's opposition remarked that it looked like a salamander. The combination of the words 'Gerry' and 'salamander' gave birth to the term 'gerrymander'. See: George Athan Billias, Elbridge Gerry: Founding Father and Republican Statesman (Toronto and New York: McGraw Hill, 1976), 313; 316-317. 
more effectually than he has by this Bill." 68 While the revising barrister clause of the

Conservatives' franchise bill would undoubtedly cast doubt upon the impartiality or

fairness of future federal elections, it also potentially jeopardized the seat of every sitting

Liberal within the House of Commons. To preserve their own positions within

Parliament, Liberals such as Cameron denounced this aspect of the Prime Minister's

franchise legislation.

While Liberal sympathizers within the Canadian press unsurprisingly joined

their Parliamentary comrades in denouncing the revising barrister clause - such as Grip

magazine's J. W. Bengough through his highly effective satirical cartoons - independent

newspapers also joined in on the attack. ${ }^{69}$ For the editor of the independent Montreal

Star, "The Revising Barrister clause is a dangerous one": through it "the country will find

itself saddled with the possibility that any Government can let loose upon it a horde of

political thugs - of agents having the power, while irresponsible themselves, to

disfranchise - kill politically - electors whom they know to be of the opposing party."70

${ }^{68}$ Hansard, vol. XIX, 16 April 1885, 1143.

${ }^{69}$ During the franchise debates of 1885 , the partisan nature of Prime Minister Macdonald's franchise act (and more particularly the revising barrister clause) represented one of Bengough's favourite targets. While he drew multiple cartoons on the subject, Bengough's cartoon of May 2, 1885 entitled "A Bird's-Eye View" perhaps best reflects his view of the legislation. With tongue planted firmly in cheek, Bengough expanded upon his cartoon with the following lines: "Grip has turned this matter over in his mind, and has just one amendment to propose. It is, to let the Revising Barristers do the voting. This would save time, trouble and expense, and would no doubt be satisfactory to the Government." As one can clearly see, Bengough's words mirrored the barbs hurled across the House of Commons floor by Liberal Members of Parliament. See: J. W. Bengough, "A Bird's-Eye View", Grip, 2 May 1885, 2; 5. For the cartoon itself, see Figure 1.

70 "The Grits and the Franchise Bill", Montreal Daily Star, 16 May 1885, 2. Hamilton's Palladium of Labor, an independent labour journal, employed even harsher words to describe the Electoral Franchise Act's revising barrister clause. As its editor argued, Prime Minister Macdonald "broached his revising barrister scheme as an engine of corruption and disfranchisement, and will not be guided even by tho [sic] alarmed remonstrances of his own followers..." See: "Manhood Suffrage", Palladium of Labor, 6 June 1885, 2. Not all independent Canadian newspapers followed the Star's and the Palladium's lead, however. For example, the independent Toronto Telegram remarked that "So long as the revising barristers who are appointed happen to be judges the Reformers will not be able to find much insult. Whatever may be said of the bar, or individual members of it, nothing but good can be said of the bench, or of its 
The potential for electoral corruption was so obvious that the Governor General himself, Lord Lansdowne, wrote Macdonald on the subject. Ever the diplomat, in the brokerage sense of the term, he chose his words carefully when he inquired: "Would it be irresponsible to allow the original draft of the list to be prepared by a municipal officer or body?...If something of the kind could be done the argument that the revising officer might subtract at the outset the names of political opponents would be effectively demolished." ${ }^{\text {71 }}$ Even those Canadians who reportedly did not maintain party affiliations - from the humble newspaper editor all the way to the Queen's representative in Canada - therefore worried about the highly partisan nature of the new franchise act's revising barrister clause. ${ }^{72}$ Despite these accusations of transparent partisanship from both inside and outside the Liberal party, Conservative Canadians were decidedly unapologetic.

Considering the fact that the provincial governments had appointed their own revising barristers for provincial elections since the pre-Confederation period, contemporary Conservative commentators viewed opposition arguments against the revising barrister clause as hypocritical. True, the clause would not eliminate the chance of electoral corruption. Still, under the new Electoral Franchise Act, that chance would arguably be no greater than in any provincial election held across the country. By means

individual members." See: Toronto Evening Telegram [editorial], 9 October 1885, 4. For the political affiliation of the Star and the Telegram, or lack thereof, see: Rutherford, 237; 239.

${ }^{71}$ LAC, Sir John A. Macdonald fonds, MG 26-A, "Political papers. Subject files" series, volume 85, reel C1516, pages 33083-33084, letter from Lord Lansdowne to Sir John A. Macdonald, 29 May 1885.

${ }^{72}$ Aside from these political attacks, some Canadians took such umbrage with the revising barrister clause that they went so far as to threaten Prime Minister Macdonald with physical violence. For example, an anonymous writer addressed the following ominous lines to Macdonald: “... and now the Bill you have before Parliament takes the franchise from the Provinces and put them in the hands of hired Barristers and Bailiffs will caus[e] [sic] the Balls to fly thicker at Ottawa than they have in the North west you deserve a ball hole in your head and you shall have it." While he or she makes no mention of it, one can assume that the disgruntled writer had Liberal tendencies. See: LAC, Sir John A. Macdonald fonds, MG 26-A, "Political papers. Subject files" series, volume 415, reel C1771, page 200957, letter from Anonymous to Sir John A. Macdonald, May 1885. 
Figure 1

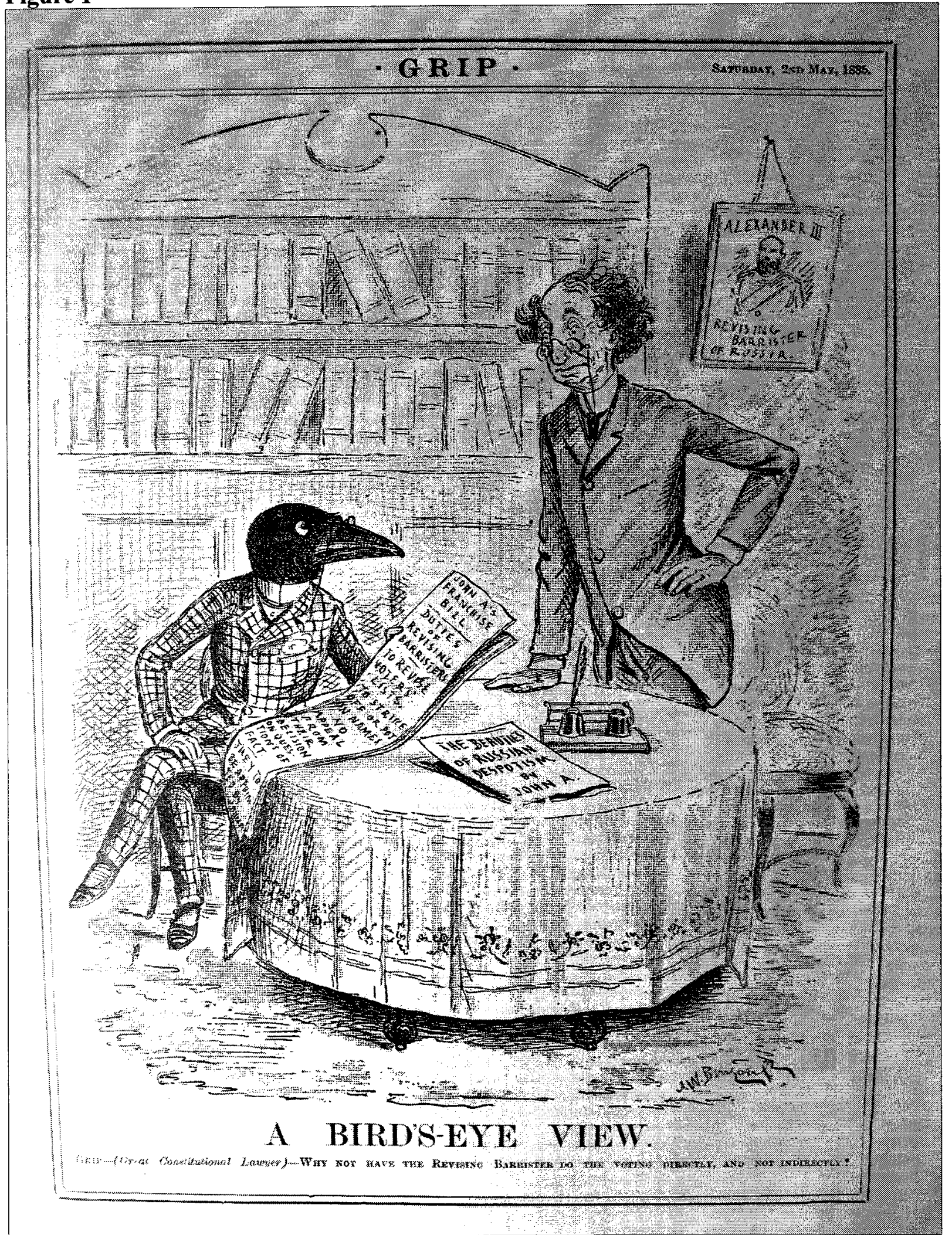

J. W. Bengough, “A Bird's-Eye View”, Grip, 2 May 1885, 5. 
of sarcastic language, The Brandon Mail - a Conservative farmers' newspaper published out of Brandon, Manitoba - offered perhaps one of the best synopses of this supposed Liberal hypocrisy when its editor wrote:

It is outrageous to place such powers in the hands of a judge under a Tory administration, but it was all right for a lot of Grit rascals, in the late Algoma election, to disfranchise many of the electors by refusing to open booths in localities where it was known there was a strong Tory vote; and more honourable still for the GritGovernment [sic] to pass a whitewashing bill to exonerate these rascals from the penalties that would otherwise have been imposed on them for their nefarious acts... ${ }^{73}$

As the editor of the Mail contended, Liberal provincial governments, for years, had used their power to appoint revising barristers for partisan gain at election time. In response, the Conservatives could apparently do nothing. Only now that new franchise act gave the Conservatives the same sort of power did the Liberals apparently feel the need to decry such partisan tactics. ${ }^{74}$ Consequently, Prime Minister Macdonald's Conservative government saw no reason to alter its stance on the revising barrister clause. Not only did it give them control over a slew of new patronage positions, but they had precedent on their side. The Conservatives, therefore, got the increased centralized power that they wanted. Yet, one must remember that the Electoral Franchise Act of 1885 did more than just shift control over the Canadian franchise to the federal government. Just as importantly, it also established new, more restrictive franchise qualifications for future

73 "The Franchise Bill", The Brandon Mail, 28 May 1885, 4.

${ }^{74}$ Once the federally-appointed revising officers began to undertake their duties in 1886 , Liberal attacks against their supposedly partisan character picked up even greater momentum. For example, when the Liberal Toronto Globe published its reports of the courts of revision for East York, it decried the Conservative tendencies of the aforementioned Judge Edward Morgan. Feeling that he struck too many worthy Liberals from the county's voters' list, the Globe referred to the court's apparently partisan process as "Morganization". See: "Morganization", Toronto Globe, 22 June 1886, 1; "Further Morganization", Toronto Globe, 23 June 1886, 1. 
federal elections and thereby bucked the trend evident at the provincial level since Confederation.

Ever since the Confederation delegates drafted Canada's inaugural franchise legislation, Canadians' thoughts concerning the shape of the franchise had begun to change. Seeing the example set by British Parliament in 1867 when the Second Reform Act engineered a sizable expansion of its own franchise, many of the Canadian provinces had followed suit (generally while under the direction of Liberal governments, as previously mentioned) ${ }^{75}$ With more Canadians receiving the franchise, the demand for even more inclusive franchise legislation increased. By the early 1880 s, radically independent newspapers such as The Toronto World and the Toronto Evening News began to call for radical franchise expansion, to the point of manhood suffrage. ${ }^{76}$ These newspapers did not simply serve a handful of republican ideologues either: the World had an average circulation of 8,000 copies in 1880 while the News on average circulated 17,489 copies. ${ }^{77}$ Groups of disenfranchised Canadians themselves also increasingly stood up for their alleged right to the franchise. In post-Confederation Canada, most disenfranchised Canadians were either women or working-class men. Although the women's suffrage movement had yet to gain any real momentum, Canadian labourers had organized themselves as a national political force by the early 1880 s. $^{78}$

\footnotetext{
${ }^{75}$ The British example to which this sentence refers is the Reform Act of 1867. Further on, this chapter discusses the Reform Act in greater detail.

${ }^{76}$ For examples of the World's and the News's views of the franchise, see: "The Political Franchise", The Toronto World, 31 October 1883, 2; "A Popular Question", Toronto Evening News, 26 November 1883, 2.

${ }_{77}^{7}$ See: Rutherford, 239.

${ }^{78}$ As Carol Lee Bacchi explains, the women's suffrage movement in Canada began to hit its stride only after the turn of the twentieth century. During the nineteenth century, any demands for women's suffrage tended to emanate from women's groups that linked themselves to other social causes, such as the temperance movement. Indeed, according to Bacchi, before 1900, only a handful of societies explicitly dedicated to the promotion of women's suffrage existed in Canada. Of these societies - the Canadian
} 
Certainly, trade unions still represented workers' interests at the local level. With the formation of the Canadian Labor Congress in 1883, however, these unions could finally unite around a strong central organizational force. In its first meeting, the Congress unanimously carried the motion that it would petition for the institution of manhood suffrage. ${ }^{79}$ After changing its name to the Trades and Labor Congress of Canada, the Congress reiterated the same "demand [for] manhood suffrage at the hands of our legislators" in its second meeting in the summer of $1886 .{ }^{80}$ As the mouthpieces for labour's organizational bodies, Canada's labour newspapers also spoke in favour of a more inclusive franchise. For example, Phillips Thompson (under the pseudonym Enjolras), the leading contributor to Canada's leading labour newspaper, Hamilton's Palladium of Labor, recognized the restricted franchise as an abuse against Canada's workers. ${ }^{81}$ While Thompson believed every Canadian man should have the vote - and every Canadian woman for that matter - he also believed that labourers were not doing

Woman Suffrage Association (of Toronto) [CWSA], the Dominion Women's Enfranchisement Association (also of Toronto) [DWEA], the Saint John Suffrage Association, and the Manitoba Equal Suffrage Club only two existed before the passage of the Dominion Franchise Act of 1885: the CWSA and the DWEA. The others formed in 1894. Despite the existence of these societies, Bacchi concludes that "In 1895 the suffrage movement stood in no-man's land. The few feminist founders were old and tired. The vast majority of women were unconcerned or unconverted." See: Bacchi, 27-30. That said, Prime Minister Macdonald did receive approximately eight letters - five by private individuals and three by suffrage organizations - that requested the establishment of women's suffrage federally in Canada. While those letters by private individuals tended to originate within Canada (with the exception of Lady Clara E. L. Rayleigh of England), two of the organizational letters actually came from other countries (from the Victorian Women's Suffrage Association of England, and the New York State Woman Suffrage Association) where the women's suffrage movement had more support behind it. The sole Canadian organizational letter was penned by Jessie McEwen, president of the recently formed Canadian Woman Suffrage Association. See: LAC, Sir John A. Macdonald fonds, MG 26-A, "Political papers. Subject files" series, volume 393 part 1, reel C1761, pages 187472 to 187476 , letter from Jessie McEwen to Sir John A. Macdonald, 17 April 1883.

${ }^{79}$ Canadian Labor Congress, Proceedings of the Canadian Labor Congress, held in Toronto, On Wednesday, Thursday, and Friday, December $26^{\text {th }}, 27^{\text {th }}$, and $28^{\text {th }}, 1883$ (Toronto: Roddy \& Nurse, 1884), 24-25.

${ }^{80}$ Trades and Labor Congress of Canada, Proceedings of the Trades and Labor Congress of Canada, held in Toronto, On Tuesday, Wednesday and Thursday, September $14^{\text {th }}, 15^{\text {th }} \& 16^{\text {th }}, 1886$ (Toronto: Labor Record Print, 1886), 13.

${ }^{81}$ Enjolras, "Labor and Politics", Palladium of Labor, 12 April 1884, 1. See also: Verzuh, 52. 
enough to assure their own enfranchisement. ${ }^{82}$ Admonishing the "political apathy and partizan spirit" that slowed labour's political progress, the Palladium trumpeted its rallying cry: "It is only by remaining aloof from these [political] organizations, and acting independently of party issues that our object can be attained. ${ }^{, 83}$ As historian Bernard Ostry reveals, established loyalties to Canada's existing political parties above all else helped muffle labour's demands for an expanded franchise. ${ }^{84}$ Instead of forming a united front in support of the labour cause, labour leaders' interests tended to splinter along party lines and, consequently, promote either Conservative or Liberal policy positions. Even so, by the time John A. Macdonald tabled his franchise bill in 1885, many disenfranchised labouring Canadians (and those who supported their efforts) asserted more pressure on their political representatives for an expanded franchise than ever before. ${ }^{85}$ As the so-called 'workingman's friend' - a nickname he acquired in the 1870 s for his labour reforms, his legislation to legalize trade unions, and his apparent ability to maintain prosperous economic conditions - Macdonald seemed well positioned to solidify his reputation and provide Canadian labour organizations what they demanded. ${ }^{86}$ Macdonald's legislation did the exact opposite.

\footnotetext{
${ }^{82}$ Enjolras, "Democracy", Palladium of Labor, 24 May 1884, 1.

${ }^{83}$ Enjolras, "Political Power", Palladium of Labor, 7 June 1884, 1; "Labor's Opportunity", Palladium of Labor, 9 May 1885, 1.

${ }^{84}$ Bernard Ostry, "Conservatives, Liberals, and Labour in the 1880s", Canadian Journal of Economics and Political Science 27.2 (May 1961), 156.

${ }^{85}$ Of course, just how much pressure labour groups actually placed on the federal government when it came to franchise reform is open for debate. Considering Macdonald apparently restricted Canada's federal franchise despite the vocalizations of these labour groups, it seems that the amount of pressure applied was not great enough for the government to take seriously.

${ }^{86}$ Ostry in Canadian Journal of Economics and Political Science, 153. By 1885, however, the workers' Palladium of Labor did not view Prime Minister Macdonald in the same positive light. According to its editor, "[f]ew years ago [when he portrayed himself as the workingman's friend] Sir John Macdonald would have seen his opportunity and got out of the fix by declaring for manhood suffrage." Now, however, "Sir John has grown so obstinate and pig-headed in the days of his dotage that he will listen to neither friend nor foe." In summation, the Palladium believed "the old man is not what he used to be"-
} 
As previously stated, the Electoral Franchise Act made Canada's federal franchise no more accessible than before. Because most provincial governments had expanded their franchises since the time of Confederation, the new legislation and its stress upon personal assets arguably ensured that greater numbers of Canada's working poor would legally remain without a vote for years to come. While such a restriction of the franchise may have been exceedingly unpopular amongst disenfranchised or otherwise liberalminded Canadians, it seemingly followed one ideological tradition almost to the letter: that of Burkean conservatism. Not only did it place further limitations upon the number of federal voters, just as Edmund Burke advocated, it also based these limitations upon one's personal assets. Under the new franchise act, property and income would remain the sure foundation of political citizenship. This conservative predilection was not lost upon Members of Parliament. During the House of Commons debates concerning the franchise bill, the Conservative member for Beauce, Quebec, Thomas Linière Taschereau, wholeheartedly endorsed the franchise bill for this very reason. Affirming the legislation's fundamentally conservative orientation, he announced that

I shall give my vote in favor of the second reading of this Bill, for the chief reason that it contains a conservative idea, a conservative principle, and that it is conservative in its very essence. It is conservative as a whole, and will be conservative in its consequences...[Y] ou will find in it the suffrage given to the elector who is owner of property, or lessee, or who has a certain income. This is the essence of the conservative principle, as regards the right of suffrage. ${ }^{87}$

Of course, such obvious conservatism irked the opposition Liberals to no end. They predictably viewed it as "retrograde legislation, striking at the rights and privileges of the

and especially when it came to the working population of Canada. See: "Manhood Suffrage", Palladium of Labor, 6 June 1885, 2.

${ }^{87}$ Hansard, vol. XVIII, 21 April 1885, 1236. 
people and depriving them of a privilege they have possessed for years". ${ }^{88}$ As

Taschereau observed, however, the legislation was not designed to satisfy liberal minds: it was instead "conservative in its essence, and for this reason it was right it should be introduced by the leader of the Conservative party". ${ }^{89}$ Considering the Prime Minister's earlier inclinations toward Burkean conservatism, the fact that Macdonald consciously drafted a piece of franchise legislation steeped in conservative political philosophy should not have been unexpected.

According to Macdonald's private secretary, Joseph Pope, the Prime Minister had two main aims in mind when he first drew up the Electoral Franchise Act of 1885 . While Macdonald had touted the first of these reasons - "uniformity of the suffrage" - in both the House of Commons and his letter to Lord Carnarvon, he never made the second as explicit, "the recognition of a property qualification as determining the right to vote." 90 As he did with Canada's inaugural franchise, Macdonald apparently created franchise legislation that satisfied one of the basic tenets of conservative political philosophy: that, above all else, property ownership and personal wealth should remain the principal criteria for political citizenship. Moreover, through his legislation, the Prime Minister apparently wanted to keep it that way. When Macdonald fashioned Canada's first federal franchise law in 1865, rigid property qualifications represented the norm in Canada. Consequently, very few Canadians had the vote. Now that many provinces had reduced their property qualifications to only nominal levels - or had basically eliminated them in the cases of British Columbia and Prince Edward Island - the conservative, property-

\footnotetext{
${ }^{88}$ Ibid., 15 May 1885,1860 . The citation itself comes from a speech by Liberal member for Wellington North, Ontario, James McMullen.

${ }^{89}$ Ibid., 21 April 1885, 1236.

${ }^{90}$ Pope, 247.
} 
based franchise in Canada seemed to edge ever closer to extinction. With 1885's

Electoral Franchise Act placing the federal franchise solely under the (Conservative)

Dominion government's control, the provinces had no power to continue their

liberalization of Canada's franchise law. The conservative ideology that underpinned the

act would consequently live within the federal statute books for the foreseeable future (or

until the Liberals took power and decided to alter the legislation). Yet, this promotion

and preservation of Burkean conservatism within Canada's franchise apparently

participated in a much grander purpose. As Liberal provincial governments extended the

franchise, greater numbers of Canadians outside Quebec began to demand more liberal

franchise legislation. ${ }^{91}$ With this spread of liberal political ideology came changes to the

${ }^{91}$ In terms of the franchise, very little had changed in Quebec since the time of Confederation. While the Quebec legislature had passed a franchise reform in 1875 , the new legislation did not change the property qualifications for enfranchisement in any way. As a result, Quebec's franchise in 1885 was the most restrictive in the country. Moreover, the conservatism that held sway with regard to the franchise in Quebec remained as present as ever. Although the new Roman pontiff, Pope Leo XIII, sought to reconcile Catholicism with the modern world, as late as his Encyclical of 1888 he referred to "Liberalism" as "simply a road leading straight to tyranny." As these words clearly indicate, the Catholic Church (despite a new pope) still resisted any policy that smacked of republicanism. Consequently, the vast majority of Quebecers saw no need to alter their highly restrictive franchise law. As a young Wilfrid Laurier put it to the House of Commons, "I believe the members from the Province of Quebec will admit that universal suffrage would not be suitable to the majority of the people of our Province." In an 1883 letter to his party leader, Edward Blake, Laurier more fully expressed his sentiments concerning Quebecers' beliefs concerning the suffrage. As he wrote: "Still, any one conversant with the internal life of this province must have a pretty accurate opinion of what will be the expression of public opinion, whenever public opinion is expressed on the subject. The expression will be a strong disapproval of manhood suffrage, \& concession of suffrage to women, however restricted. The reason is that the clergy have very determined ideas, already, on the subject. You are aware that the clergy of this province, at all times, but especially since communications have become more easy \& frequent between the two continents, have always taken a deep interest in the politics of France. The information has been uniformly $\&$ solely derived from the ultramontaine press, which has bee \& is yet rabbid [sic] against universal suffrage. You are also aware that the clergy, in the politics of this province, have always applied the same standard which guided their sympathies abroad, even when the questions under discussion here \& abroad were at a total variance. So, I think I am exactly written the very truth when I say that the clergy will be unflinchingly opposed to universal suffrage: $\&$ the expressed opinion of the clergy wil [sic] be the opinion of the vast majority of the people." Obviously, Laurier felt that the general sentiment against universal manhood suffrage in Quebec stemmed from the power of the Catholic Church in the province. See: Catholic Church, "Human Liberty" (20 June 1888), The Great Encyclical Letters of Pope Leo XIII (New York: Benzinger Brothers, 1903), 146 [emphasis in text]; Holland, 168; Hansard, vol. XVIII, 17 April 1885, 1169; LAC, Edward Blake fonds, MG 27-ID2, "Canadian political correspondence" series, "Correspondence with specific individuals 
nation's political culture. Although Confederation had only taken place eighteen years earlier, the ideology that served as the groundwork of the Canadian state had shifted noticeably away from conservatism and toward liberalism. Through his decidedly conservative piece of franchise legislation, Prime Minister attempted to prevent the liberal tide from washing over Canada completely. He instead hoped to promote a reorientation and a re-formation of the Canadian state.

In his apparent effort at what modern scholars call state formation - the conscious exercise of state power to transform a given culture so that the state may gain a cultural acceptance of itself and its goals - through franchise reform, Prime Minister Macdonald was attempting nothing new. ${ }^{92}$ Indeed, the one politician he perhaps admired above all others, former Conservative British Prime Minister Benjamin Disraeli, had done much the same thing nearly eighteen years earlier with the so-called Second Reform Act of $1867 .{ }^{93}$ Throughout the $1850 \mathrm{~s}$ and $1860 \mathrm{~s}$, popular demand for an expanded suffrage had increased in England. ${ }^{94}$ While the British government under Whig Prime Minister Lord Grey had extended the franchise in 1832 with the so-called Great Reform Act, the $£ 10$ property qualification ensured that very few working class Britons would have had access to the vote. ${ }^{95}$ As public pressure mounted, Lord Russell's Liberal ministry decided to act and, in 1866 , introduced a reform bill to the House of Commons that would have significantly expanded the nation's franchise. After the bill's failure, the Russell ministry

(Canadians or persons connected with Canada)", reel M240, paper 20, page 1, letter from Wilfrid Laurier to Edward Blake, 10 December 1883. Emphasis in text.

${ }_{92}^{92}$ For a discussion of this definition of state formation, see pages 33-35 of this thesis.

${ }^{93}$ After they met for the first time in 1879, Disraeli remarked of Macdonald: "He is gentlemanlike, agreeable, and very intelligent; a considerable man..." See: Creighton, The Old Chieftain, 274.

${ }_{95}^{94}$ Hall et al., 2.

${ }^{95}$ Michael Brock, The Great Reform Act (London: Hutchinson University Library, 1973), 321. See also: Hall et al., 1. 
resigned and workers' demands for enfranchisement increased; the threat of rioting and violence emerged, as typified by the so-called Hyde Park riots of July, $1866 .^{96}$ Receiving a minority mandate after Russell's resignation, Lord Derby's Conservatives took control over the reigns of government. With public pressure still mounting, and the Parliamentary contest between Conservatives and Liberals intensifying because of the minority situation, both sides of the House of Commons reportedly "view[ed] that the reform question had to be settled." 97 In February of 1867, as Conservative leader of the House of Commons, Disraeli introduced the bill that would eventually become the Second Reform Act. Although with it he in part sought to pacify the many Britons who demanded reform, it seems that he also had much more ambitious motivations in mind when it came to the state.

\footnotetext{
${ }^{96}$ As a way to pressure Parliament for a more inclusive franchise, England's Reform League (formed in 1865 to pressure the government to introduce manhood suffrage) organized a mass demonstration to take place in London's Hyde Park in July, 1866. The Parks Regulation Meetings Act of May 3, 1866, however, had made such a gathering illegal. When police barred the reformers from entering the park on the evening of July 23,1866 , the agitated crowd pulled down the railings that surrounded the park. Although Lancaster University historian Eric J. Evans has called the "so-called Hyde Park riots small beer indeed in the context of nineteenth-century agitation", the London Times had a much more sensational take on the events. Chronicling in detail the damage to the park that left it "a pitiable spectacle", the injuries (and deaths) suffered by both the crowd and the police, and the charges laid, the Times generally concluded that "It is a scandal to our civilization that such proceedings as those which prevail in Hyde Park at night should be tolerated anywhere." See: James Vernon, Politics and the People: A study in English political culture, c. 1815-1867 (Cambridge: Cambridge University Press, 1993), 214; George Macaulay Trevelyan, British History in the Nineteenth Century (1782-1901) (London, New York, and Toronto: Longmans, Green and Co., 1933), 345; Eric J. Evans, The Forging of the Modern State: Early industrial Britain 1783-1870, $3^{\text {rd }}$ ed. (Harlow: Pearson, 2001), 436. For the London Times's take on the demonstrations, see: "The Reform Demonstration in Hyde Park", London Times, 24 July 1866, 9; "The Hyde Park Rioters", London Times, 25 July 1866, 5; "The Rioting in Hyde Park", Ibid., 9; "The Riots in Hyde Park", London Times, 26 July 1866, 10; "The Hyde Park Rioters", London Times, 27 July 1866, 5. For the Times's editorial generalization about the park, see: London Times [editorial], 1 August 1866, 9.

${ }^{97}$ Hall et al., 4. As Hall, McClelland and Rendall explain, historians are divided as to the direct catalyst of the Second Reform Bill. On the one hand, some contend that public outcry and the threat of violence reached such proportions that Parliament had to act. On the other hand, "many historians would nevertheless argue that it was the parliamentary battle, rather than such external pressures, which determined the precise timing and shaped the provisions of the Reform Acts." While the authors unfortunately never cite the historians to which they refer, it seems they somewhat prefer the first, more populist explanation. As one will see in the upcoming pages of this chapter, British historian Gertrude Himmelfarb would beg to disagree. See: Ibid.
} 
With regard to the most current body of work on the Second Reform Act, scholars agree that political opportunism, not public pressure, represented the principal catalyst for franchise reform. As British historian Gertrude Himmelfarb explains in her noteworthy essay on democracy and the Second Reform Act, Disraeli himself was "it would seem, more concerned with the future than the people whose future was being decided."98 While most Conservatives remained content with previous (restrictive) franchise legislation, Conservative leaders apparently felt that they could turn the volatile situation to their profit. ${ }^{99}$ When the Conservatives first introduced their Reform Bill on March 18, 1867, it was, as University of London historian Paul Smith describes it, "a very limited and conservative measure." 100 While the bill contained no property qualifications for urban ridings other than the stipulation that a voter must occupy a household, its various "checks and counterpoises" ensured that it would have little effect on the size of the electorate. ${ }^{101}$ Such an outcome would have undoubtedly pleased Burkean conservatives. When, however, the unpopularity of such conservatism both inside and outside the House of Commons reached Disraeli and threatened to topple his minority government, he struck his checks and balances from the legislation. This action ultimately resulted in a

${ }^{98}$ Gertrude Himmelfarb, “The Politics of Democracy: the English Reform Act of 1867”, Journal of British Studies 6.1 (1966), 103. 1967), 91.

${ }^{99}$ Paul Smith, Disraelian Conservatism and Social Reform (Toronto: University of Toronto Press,

${ }^{100}$ Ibid., 89-90.

${ }^{101}$ T. A. Jenkins, Disraeli and Victorian Conservatism (New York: St. Martin's Press, 1997), 7677; Paul Smith, 90-91. According to the bill, Britons living in rural constituencies still had to own property ( $£ 12$ worth) to qualify for the franchise. Still, a small minority of Conservatives viewed such a franchise, while seemingly conservative, as too liberal to either endorse or accept. In an interesting turn of events, Prime Minister Macdonald's overseas confidant, Lord Carnarvon, was among these unhappy British Conservatives. In 1867, Carnarvon sat in the House of Lords. Opposed to the sort of "radical settlement" Disraeli eventually proposed, he (alongside Lord Cranborne, the Secretary of State for India, and General Jonathan Peel, the Secretary for War) resigned their seats in protest. In light of these events, Carnarvon would have been much happier with the details of Macdonald's franchise reform than those of Disraeli's bill. See: Ibid., 77. 
radically expanded franchise when compared with the Reform Act of 1832: while it did not institute manhood suffrage, estimates indicate that the number of enfranchised Englishmen increased by eighty to one hundred percent. ${ }^{102}$ Such a massive expansion of the franchise certainly did not coincide with Burkean conservative ideology and its emphasis on restrictive franchises to increase the value of each individual vote. Indeed, many opponents of the billed likened it to 'shooting Niagara'. That said, Disraeli did not give up his legislation's various internal counterpoises without receiving something valuable in return.

Although Disraeli's Conservatives may have had to endure a franchise enlargement perhaps too radical for their tastes, the redistribution of House of Commons seats they received apparently made up for it. According to Cambridge University historian Maurice Cowling, in his exhaustive history of the passage of the Second Reform Bill, the conservative Disraeli "had to avoid the imputation of restrictiveness" in the franchise to obtain the sort of redistribution he desired. ${ }^{103}$ By amalgamating smaller urban constituencies, the Conservatives managed to free up fifty-two seats to supposedly serve the massive influx of new (primarily working class) voters. While the vast majority of these newly enfranchised voters tended to live in the country's urban centres (otherwise known as boroughs), Disraeli doled out twenty-five of the fifty-two reclaimed

${ }^{102}$ Daren Acemoglu and James A. Robinson, "Why Did the West Extend the Franchise? Democracy, Inequality, and growth in Historical Perspective", The Quarterly Journal of Economics 115 (November 2000), 1183; Paul Adelman, Gladstone, Disraeli \& Later Victorian Politics, $3^{\text {rd }}$ ed. (London and New York: Longman, 1997), 19. While Adelman only gives a percentage of increase (one hundred percent, in this case), Acemoglu and Robinson cite that the number of voters expanded from 1.4 million to 2.52 million. The different between these two figures translates to eighty percent.

${ }^{103}$ Maurice Cowling, 1867: Disraeli, Gladstone and Revolution (Cambridge: Cambridge University Press, 1967), 308. 
urban seats to the much less populated rural counties. ${ }^{104}$ Indeed, contemporary electoral statistics indicate that the redistribution resulted in twenty-eight additional seats for England's counties and thirty-seven fewer seats for its boroughs. ${ }^{105}$ Rural votes consequently became much more valuable and the rural electorate had a much greater representation in the House of Commons. As both Cowling and former Kingston University historian Paul Adelman argue, this is just what Disraeli and the Conservatives wanted. ${ }^{106}$ Throughout much of its history, the English Conservative party had relied upon the traditionally conservative, landholding inhabitants of England's counties for their electoral success (where the property qualification still remained in place, now pegged at $£ 12) .{ }^{107}$ Urban voters at this time, on the other hand, tended to vote Liberal. ${ }^{108}$ Although Disraeli's franchise reform would have created swathes of new Liberal voters, their votes would have wastefully piled up behind the same few urban Liberal candidates. Not only did such a redistribution of seats effectively staunch the apparently democratic elements of Disraeli's franchise reform, it consequently sought to ensure that political power would rest with the nation's rural landholding conservative (and Conservative) voters. ${ }^{109}$ The 1867 act was, therefore, not a surrender to Liberal imperatives, but instead a shrewd tactical response to them.

Undoubtedly, Disraeli sought to improve his party's, and his own, political fortunes through his Reform Act. As the leader of a minority government engaged in a

${ }^{104}$ Adelman, 19.

${ }^{105}$ More specifically, England's counties had 142 seats before the Reform Act of 1867, and England's boroughs (including London's boroughs) had 322 seats. Compare that with 170 county seats and 285 borough seats after the act's passage. See: F. W. S. Craig, ed., British Parliamentary Election Results 1832-1885 (London: Macmillan, 1977), 622.

${ }^{106}$ Cowling, 78; Adelman, 19-20.

${ }^{107}$ Adelman, 19.

${ }^{108}$ Ibid.

${ }^{109}$ Cowling, 74; Adelman, 20. 
political battle for supremacy with the stronger Liberals (including one of the foremost politicians of the nineteenth century, Liberal House leader and future Prime Minister William Gladstone), the Conservatives needed every advantage they could muster. ${ }^{110}$ But, partisan gains do not completely explain Disraeli's legislation. As Paul Adelman convincingly argues, the bill possessed decidedly conservative ideological implications as well. ${ }^{11}$ With traditionally conservative rural voters now given significantly more political weight than before (despite the rise in popular support for liberal philosophies), the opportunity opened for the introduction of expanded conservative policy. If the Reform Act also resulted in a larger Conservative return in the House of Commons, the possibility for an increased application of conservative ideology would have held especially true. Disraeli's Reform Act, while perhaps outwardly democratic, therefore constituted an attempt at conservative state formation. Possibly, as Maurice Cowling suggests, the Conservatives may have preferred to implement a restrictive franchise "[i]f a restrictive Act could have been passed". ${ }^{112}$ Because of the unstable political situation in England at the time, however, Disraeli had to pursue a conservative reorientation of the English state in a less conventional, and perhaps more devious, way. ${ }^{113}$ Considering the precedent set by Benjamin Disraeli in 1867, it does not seem particularly far-fetched that

${ }^{110}$ Eric J. Evans relates that during the 1868 election the Tories managed to capture seventy-five percent of the seats that represented the English counties. Compare that with the Liberals winning 125 of the 159 seats representing the larger English boroughs. From a partisan point of view, Disraeli was consequently correct in emphasizing the rural English voter with his reform. See: Eric J. Evans, 444.

111 Adelman, 19.

${ }^{112}$ Cowling, 310.

${ }^{113}$ Paul Smith writes that after having made concessions with regard to his franchise legislation, Disraeli "tried deviously to limit" their effects. See: Paul Smith, 92. Although, as previously mentioned, the Conservative's won seventy-five percent of rural ridings during the 1868 election, the party lost one seat in England. It therefore seems that Disraeli's machinations failed to have the desired results. That said, the percentage of the popular vote the Conservatives garnered remained steady. If Disraeli managed to impose the wholly conservative franchise reform Macdonald managed to pass, the election results in Great Britain may have been different. See: Craig, ed., 626. 
John A. Macdonald would have made his own attempts at state formation through franchise reform in 1885 .

Even before Macdonald passed his suffrage legislation, contemporary commentators, such as Joseph Tassé of Montreal's La Minerve newspaper, drew strong parallels between Macdonald and Disraeli, and their approaches to politics. ${ }^{114}$ Aside from their strong mutual admiration, Tassé highlights in particular that the two were masters of parliamentary strategy: not only did "they know how, better than any of their compeers, by the selection of their words, to control a House, to mould it in favour of their own ideas, their own sentiments", they "excelled in masking the points of their play, in detecting the weak places in their opponents' cuirass, and in placing snares at their feet which it was almost impossible for them to avoid."115 Both Disraeli and Macdonald certainly employed these talents to their fullest when it came to the conservative aims that lay behind their franchise reforms. Indeed, when it came to the two franchise reforms, the principal difference hinged on the fact that Macdonald managed to pass his desired legislation principally intact while Disraeli had to compromise significantly to get what he ultimately wanted.

\footnotetext{
${ }^{114}$ In the introduction to his biography of Macdonald, Richard Gwyn more generally links Disraeli and Macdonald as two of the top four democratic leaders of the nineteenth century. Gwyn ensures to preface his remark by telling the reader he made this decision "[e]ven without the spur of chauvinism". The other two political leaders included on this list are American President Abraham Lincoln and British Prime Minister William Gladstone. See: Gwyn, 2. Editor of La Minerve for fifteen years, Tassé also served as a Conservative Member of Parliament, and, for the last four years of his life, as a senator. Although an "author of numerous historical publications", fellow French Canadian newspaperman JulesPaul Tardivel (of the Quebec City-based ultra-conservative Catholic newspaper, La Verite) remarked that Tassé was "a hard-working rather than brilliant writer". See: Jean-Marie Lebel, "Tassé, Joseph", Dictionary of Canadian Biography, vol. XII, 1026-1027.

115 Joseph Tassé, Lord Beaconsfield and Sir John A. Macdonald: A Political and Personal Parallel, trans. James Penny (Montreal: s.n., 1891), 30. Tassé originally published his text in 1880 , the year before Disraeli's death. See: Joseph Tassé, Un Parallele: Lord Beaconsfield et Sir John Macdonald (Ottawa: Imprimerie du Canada, 1880). Benjamin Disraeli became Lord Beaconsfield when he was raised to the peerage in 1876.
} 
During Canada's franchise debate in 1885, Prime Minister Macdonald did not nearly have to face the same sort of political turmoil concerning the franchise as his British counterpart. Although Canadian labour groups had become more vocal in their desire for an expanded federal franchise, the demands they made were still somewhat muted. The Dominion government certainly did not have to cope with mass demonstrations and threats of violence as a result of discontentedness with the franchise. In fact, during the spring of 1885 , when Parliament wrestled with the franchise question, suffrage reform did not even represent the most pressing news item. More Canadians instead preferred to look westward to the actions of the Canadian militia, the Métis, the First Nations, and Louis Riel during the so-called Northwest Rebellion. ${ }^{116}$ Some Liberal Members of Parliament, including St. John, New Brunswick's Charles Weldon, Lambton, Ontario's J. H. Fairbank, and former Minister of Finance Sir Richard Cartwright, went so far as to admonish the Prime Minister for using the Northwest troubles as a distraction from the Conservatives' decision to meddle with Canadians' political citizenship. ${ }^{117}$ With a strong majority supporting him within the House of Commons, and an excellent diversion without, Macdonald therefore had much better opportunity to pass the wholly

${ }^{116}$ While historians have most commonly called the events in the Northwest during the spring and summer of 1885 the Northwest Rebellion, these events have also been termed the Riel Rebellion and the Riel Resistance. Throughout the early 1880 s, the Métis inhabitants of the Northwest Territories had grown increasingly dissatisfied with the marginal treatment they had received from Ottawa. After the Dominion government had ignored Métis petitions for land, aid, and their own schools, Métis leader Louis Riel established a provisional government in the Northwest in hopes of settling Métis grievances. Unfortunately, skirmishes between the Métis, their First Nations allies, and the Northwest Mounted Police shattered the peace and compelled the Dominion government to send Canadian militia to the Northwest. After a six-week standoff, Riel was forced to surrender. During those weeks, the Northwest Rebellion riveted the attention of Canadian onlookers. See: Margaret Conrad and Alvin Finkel, Canada: A National History, $2^{\text {nd }}$ ed. (Toronto: Pearson Longman, 2007), 233.

${ }^{117}$ As Sir Richard Cartwright put it, "[p]ublic attention is concentrated on the affairs occurring in the North-West, and only a mere fragment of the attention of the press and the people will be given to this measure, no matter what consequences it involves, not matter what result may arise, or how important it may be to the whole future condition and welfare of this community." See: Hansard, vol. XVIII, 16 April 1885, 1135. For the words of Weldon and Fairbank, see respectively: Ibid., 16 April 1885, 1149; Ibid., 21 April 1885, 1227. 
conservative franchise legislation that Disraeli would have preferred. As a result, the Electoral Franchise Act could participate in conservative state formation to a much fuller extent.

While Prime Minister Macdonald may have desired to preserve the ascendency of property as the principal determinant of political citizenship, such a desire represented only the tip of the proverbial conservative iceberg. ${ }^{118}$ By framing the franchise through his restrictive qualifications based upon real property and personal wealth, Macdonald not only protected propertied interests for years to come: he also ensured that property owners would represent, to an even greater degree, the majority of voters once the new act came into effect. Indeed, even seemingly unrelated aspects of the act played into this ultimate goal. Take the legislation's various racially-based qualifications levelled against Chinese and Aboriginal Canadians, for example. ${ }^{119}$ When he addressed the House of Commons on the topic, Prime Minster Macdonald contended that Chinese individuals living in Canada had no "British instincts or British feeling or aspirations". ${ }^{120}$ Instead of finding a permanent home and raising a family as so many other immigrants have, he reasoned that "they [the Chinese] have no intention, as a people, of making a domicile of any portion of Canada; they come and work or trade, and when they are tired of it they go away, taking with them their profits". ${ }^{121}$ Undoubtedly, prevalent racial prejudices against Chinese people, as upheld by many Canadians, including many Members of Parliament,

${ }^{118}$ Again, see: Pope, 247.

${ }^{119}$ Aside from the acts racially-based qualifications, the fact that the act favoured rural Canadians over urban Canadians is quite telling. While rural inhabitants only required $\$ 150$ worth of real property to receive the federal vote (compared with $\$ 300$ for urbanites), rural Canadians were more likely to own property anyway, as mentioned in the previous chapter. It therefore seems the Electoral Franchise Act rewarded these rural property-owners simply because they tended to own real property. See: Elections Canada, 50.

\footnotetext{
Hansard, vol. XVIII, 4 May 1885, 1582.

121 Ibid.
} 
helped inform the Prime Minister's stance. ${ }^{122}$ Nevertheless, the justification that Macdonald gives for the disenfranchisement of Chinese Canadians - that they refused to make "a domicile of any portion of Canada" - speaks just as much to the conservative emphasis on property that underpinned the act. Since the Chinese inhabitants of Canada apparently, if not stereotypically, refused to purchase and settle land, the Conservatives felt that they did not deserve the suffrage.

Interestingly, the same conservative rationale ensured that certain members of Canada's First Nations would receive the federal vote for the very first time. Because Aboriginal Canadians were so-called "sons of the soil" - in other words, indigenous to Canada - Prime Minister Macdonald considered them more likely to eventually possess real property of their own. ${ }^{123}$ He consequently felt it safer, from a conservative point of view, to bestow the vote upon Aboriginal Canadians than Chinese Canadians. To be certain, however, Macdonald chose to insert a clause within the Electoral Franchise Act

${ }^{122}$ Other than the aforementioned Louis Henry Davies (Liberal member for Queen's County, Prince Edward Island), all Members of Parliament who decided to speak about Chinese enfranchisement both Liberal and Conservative - did not regard "Mongolians" as "desirable citizens to have amongst us." Most harsh of all, Nova Scotia's Douglas B. Woodworth went so far as to chastise Davies for having argued in favour of giving the vote the Chinese inhabitant, "a dirty, greasy man, a man with a long pigtail hanging down his back, unfit for human society, with a forbidding countenance, with a flat head, with pinched toes." The fact that the Commons committee agreed upon the disenfranchisement of Chinese Canadians quite quickly (within a matter of hours, when other aspects of the bill required several days of debate) demonstrates that most Members of Parliament shared similarly prejudiced views. See: Hansard, vol. XVIII, 4 May 1885, 1583-1584. Such racist language could be found outside the House of Commons as well. For example, on May 9, 1885, Grip magazine published the following fictitious letter from one "FING WING" on the question of Chinese enfranchisement: "How is it Chinaman not gette votee? Chinaman alle samee Yellow Calf, Yellow Calf gette votee. John A. bad man. He say Chinaman belly good, build Pacific Lailway, keepee laws, alle good. But he not give vote alle samee. Tell John A. Chinaman vote him if he get votee. Vote solid, sabe! Flee countly, Chinaman good as Indian. Eat lats, mice, belly good; not scalpee women like Indian. Must have votee light away." In the same issue of Grip, the leading cartoon attacked Prime Minister Macdonald's choice to enfranchise members of the First Nations, "whether civilized or not". With that in mind, FING WING's letter seems to indicate the Grip's racist belief that neither the Aboriginal Canadian nor the Chinese Canadian was "civilized" enough to receive the federal vote. For FING WING's letter, see: FING WING [pseud.], "The Chinese Question", Grip, 9 May 1885, 7. For the leading cartoon and its commentary, see: J. W. Bengough, "The Triple Alliance", Grip, 9 May 1885, 5; "Cartoon Comments", 2. For a sample of the cartoon itself, see Figure 2.

${ }_{123}$ Hansard, vol. XVIII, 4 May $1885,1582$. 
Figure 2

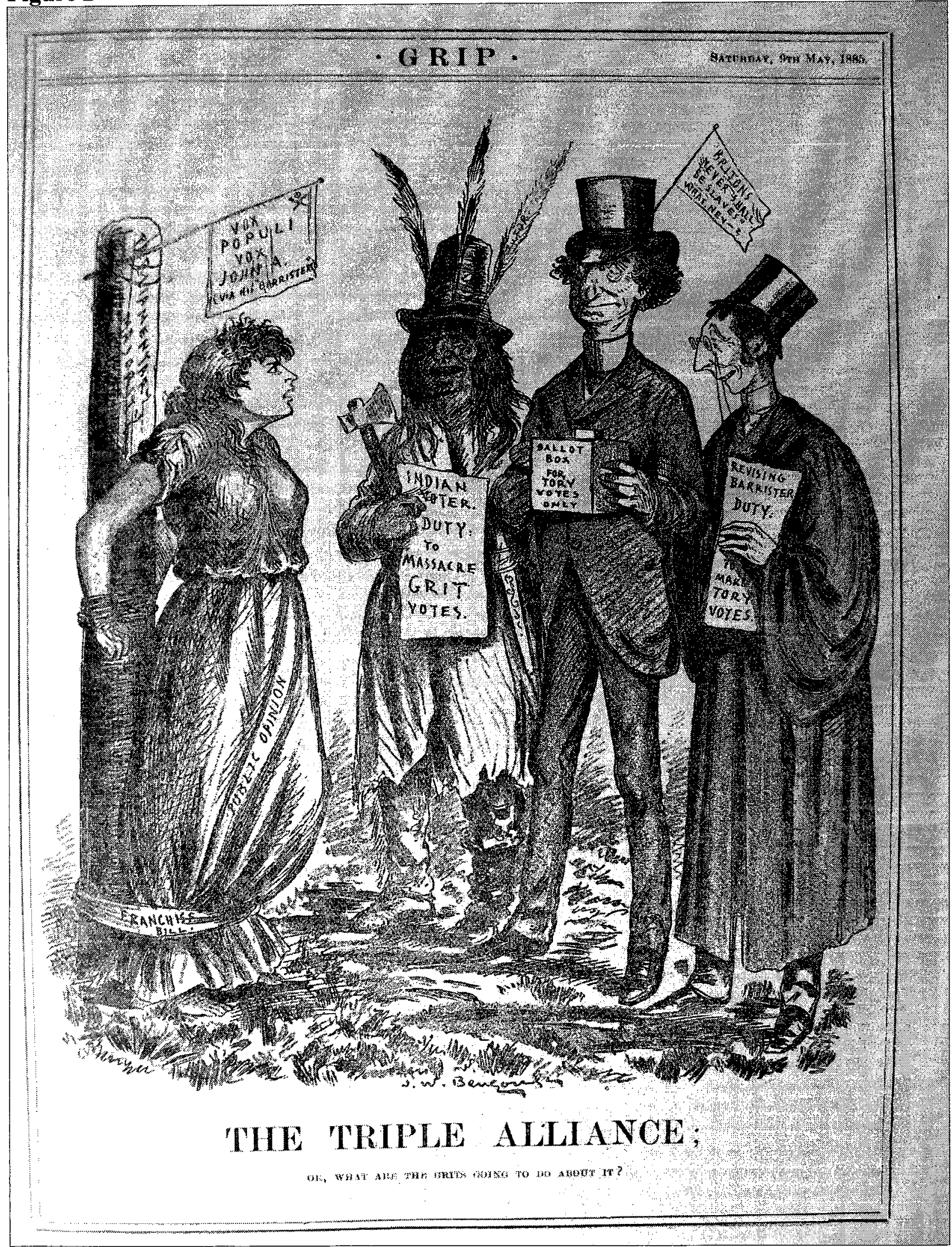

J. W. Bengough, "The Triple Alliance", Grip, 9 May 1885, 5. 
that forced Aboriginal Canadians to leave the reservation and to inhabit $\$ 150$ worth of private real estate if they wished to receive the federal vote. In other words, a Canadian of First Nations origin would have to adopt the life of a white property owner to cast a ballot federally. As a result, the Conservatives guaranteed that only property-owning members of the First Nations would gain the franchise. Yet, in his attempt to create a federal electorate composed predominantly of property-owners, Prime Minister Macdonald did not stop solely with discriminatory and exclusionist stipulations based upon racial stereotypes. In his crusade to elevate the status of the propertied classes in Canada, he forwarded a motion in his original franchise bill that many viewed as both radical and scandalous: the enfranchisement of women.

When Prime Minister Macdonald first submitted his Electoral Franchise Act to the House of Commons, its preamble made a bold and unprecedented declaration: that a “'Person' means a male person married or unmarried...or a female person unmarried or a widow." 124 With these few words, Macdonald attempted to bestow upon select Canadian women full political citizenship within the Canadian nation. Not only was such a decision unprecedented within Dominion's short history, Canada would have become the first country in the Western world to give its female inhabitants the vote. ${ }^{125}$ Yet, Macdonald evidently did not introduce women's enfranchisement out of some sense of gender equality. Although he admitted to the Commons that he "had hoped that we in Canada would have had the great honor of leading in the cause of securing the complete emancipation of women", his draft bill would have enfranchised only a small minority of

${ }^{124}$ LAC, Sir John A. Macdonald fonds, MG 26-A, "Political papers. Subject files" series, volume 64, reel $\mathrm{C} 1510$, page 25878, House of Commons "Bill No. 103: An Act respecting the Electoral Franchise", 1885. See section 2 .

${ }^{125}$ Of currently existing countries, New Zealand was the first to give women the vote. Yet, it only did so in 1893, eight years after Macdonald introduced his franchise legislation. 
Canada's female population. ${ }^{126}$ Since marriage represented the preferred status of women in Canada's highly patriarchal nineteenth-century society, Macdonald's opposition (and even members of his own party) repeatedly criticized Macdonald for drafting a piece of legislation that actually punished women for getting married. ${ }^{127}$ But, as the Prime Minister explained it, he had a very good reason for only enfranchising qualified "unmarried women and widows". ${ }^{128} \mathrm{He}$ did so, once again, "for the protection of property.",129

If few nineteenth-century Canadian women earned wages high enough to qualify for the federal franchise on the basis on income, many at least owned property. ${ }^{130}$ While married women, according to Prime Minister Macdonald, had their husbands to speak for both them and their property at the polls (a status dictated by the long-standing notion of coverture), unmarried women and widows had no similar enfranchised guardian at the voting booth. ${ }^{131}$ By extending the vote solely to this group of women, the conservative Macdonald would have, proportionally, given even greater political power to the country's property-owning classes: not only would he have reduced the number of male

${ }^{126}$ Hansard, vol. XVIII, 27 April 1885, 1388. Later in his speech on the women's franchise question, the Prime Minister even more bluntly stated "I am, however, in favor of giving ladies, married and unmarried, the franchise." See: Ibid., 1389.

${ }^{127}$ See the speeches of Wilfrid Laurier and Edward Blake in particular: Hansard, vol. XVIII, 17 April 1885, 1170; 1188 .

${ }^{128}$ Ibid., 1388.

129 lbid., 1389.

${ }^{130}$ According to the Historical Statistics of Canada, female domestics - the only women workers with available wage statistics - in 1885 earned between five dollars and sixteen dollars per month (with board) depending upon where they lived in the country. Since the best paid female domestic would only earn just shy of two hundred dollars per year in salary, none would qualify for the federal vote under the Electoral Franchise Act. See: Urquhart and Buckley, eds., 95.

${ }^{131}$ Hansard, vol. XVIII, 27 April 1885, 1389. To illustrate his point to his fellow Members of Parliament, Prime Minister Macdonald provided a short anecdote. As he stated: "It seems very hard to argue that a lady who has a large property should not have a vote when her servants may have votes. A lady of large wealth and property said to me when I was in England a short time ago: I have no vote. My butler has a vote, my steward has a vote, my coachman has a vote and at least fifty of my servants have votes; but I have no vote. She though it was rather an injustice to her that she had not a vote when so many who derived their means of living from her had votes, and were her superiors in that regard." See: Ibid. 
voters who did not own property, he would have enfranchised only those women whom he could guarantee owned property. Unfortunately for Macdonald's plans, the portion of his bill that sought to enfranchise widows and unmarried women never made it past the House of Commons committee stage. During the debate, Prince Edward Island's selfdeclared radical Liberal, the aforementioned Louis Henry Davies, represented one of the very few members on either side of the House (aside from the prime minister himself) who spoke in favour of granting the vote to women. ${ }^{132}$ Arguments against women's enfranchisement ranged from the idea that the new act punished married women, to the argument that most women did not desire the suffrage, to the notion that a woman's sex did not suit her to political life. ${ }^{133}$ Because Parliament rejected the enfranchisement of property-owning widows and unmarried women, the Dominion's electorate would not consist of quite as many property-owners when the Electoral Franchise Act finally came into effect. Even so, the alterations the Conservatives made to the Dominion franchise ensured that property-owners and the wealthy would become even more dominant politically at the federal level.

In England, as mentioned earlier, propertied interests traditionally translated into conservative and Conservative interests. Through conservatism, property-owners could better secure their property and their wealth from others (such as the government itself) who wanted to reach into their pockets or encroach upon their liberties. As historian Sydney Wise relates, such ideological dispositions had travelled across the Atlantic Ocean to nineteenth-century Canada as well. According to him, "most landowners who

\footnotetext{
${ }^{132}$ For Davies's speech, see: Hansard, vol. XVIII, 27 April 1885, 1419-1420.

${ }^{133}$ For a sampling of arguments against women's suffrage, see: Ibid., 1152; 1391; 1441.
} 
thought of themselves as gentry, not farmers, were conservatives in politics." 134 More recently, scholars have revised Wise's thesis to fold a substantial portion of farmers into this conservatism as well. ${ }^{135}$ Furthermore, the most current sociological work has argued that such contentions are true within the Canadian context all the way through to the present day. Based upon her statistical approach to the subject, St. Francis Xavier University sociologist Norine Verberg has concluded that "homeownership does have an impact on political attitudes. Homeowners are more conservative than tenants on various moral, economic, and labour issues." "136 This does not mean that all Canadian propertyowners were necessarily conservative in their political outlook. Still, if these traditions meant anything, the majority would have upheld these conservative inclinations if only to better protect their rights as property owners. ${ }^{137}$ Prime Minister Macdonald could have

${ }^{134}$ S. F. Wise, "Upper Canada and the Conservative Tradition", in Profiles of a Province: Studies in the History of Ontario, ed. Edith G. Firth (Toronto: Ontario Historical Society, 1967), 24.

${ }^{135}$ See: S. J. R. Noel, Patrons, Clients, Brokers: Ontario Society and Politics, 1791-1896 (Toronto: University of Toronto Press, 1990), 234-242. See also: Darren Ferry, "'Severing the Connections in a Complex Community': The Grange, the Patrons of Industry and the Construction/Contestation of a Late $19^{\text {th }}$-Century Agrarian Identity in Ontario", Labour/Le Travail 54 (Fall 2004), 11. According to Ferry, "[m]ore recent historiography highlights the palpable conservatism of Ontario's farming population as a justification for rejecting the militant platform of both the Grange and the Patrons of Industry [both agrarian organizations]." While less has been written on farmers' ideologies outside of Ontario, Jeffrey Taylor has argued that Manitoba farmers at the turn of the twentieth-century increasingly shared in a conservative outlook. See: Jeffrey Taylor, Fashioning Farmers: Ideology, Agricultural Knowledge, and the Manitoba Farm Movement, 1890-1925 (Regina: Canadian Plains Research Centre, 1994), 118.

${ }^{136}$ Norine Verberg, "Homeownership and Politics: Testing the Political Incorporation Thesis", Canadian Journal of Sociology 25.2 (2000), 188.

${ }^{137}$ If they had received the vote, the majority of property-owning Canadian women would have likely followed this trend as well. Just like their male counterparts, women such as Emma Gregory - "the daughter of a lifelong conservative", who in her own right owned several thousand dollars worth of property - viewed it as in their best interests to protect their personal assets as well. See: LAC, Sir John A. Macdonald fonds, MG 26-A, "Political papers. Subject files" series, volume 393 part 2, reel C1761, pages 187996-187997, Mrs. Emma Gregory to Prime Minister John A. Macdonald, 17 May 1883. In her letter to Prime Minister Macdonald, Emma Gregory admitted that she was in fact "the wife of another" lifelong conservative. Because she owned property herself, she failed "to understand why married women alone are excluded from the Franchise and would beg respectfully to ask the reason." If she, by some unhappy circumstances, had become a widow, Mrs. Gregory would have become the perfect candidate for the women's vote if the stipulation for women's enfranchisement remained within the final legislation. See: Ibid., 187996; 187998. 
expected a greater percentage of conservative voters to result from his new franchise act. $^{138}$ With proportionally more conservative voters casting their votes across the country, two separate consequences could result. First, if all these conservative voters chose to vote for the political party that best represented their ideological predilections, the Conservatives would have had a much greater chance of maintaining power. Much like Benjamin Disraeli's reform eighteen years earlier, it very much appears as if Prime Minister Macdonald altered Canada's franchise to assure his party's, and his own, reelection. Because the Conservatives won the next two federal elections and actually took more votes in the 1896 election than the victorious Liberals, one could argue that the Electoral Franchise Act played a part in the Conservative success. ${ }^{139}$ Second, and just as important, the sudden shift to a primarily conservative electorate would probably result in a corresponding shift within Canada's political culture at the federal level. With more conservatives composing the nation's body politic, conservative changes to the country's statute books would presumably be more easily accepted. If all went according to plan, the state would undergo an ideological reorientation: if it did not become more

${ }^{138}$ After the new franchise act had passed, Ontario's Conservatives released a Handy Book on the Dominion Franchise Act that described how its membership should work with the new federal legislation to best ensure a Conservative victory come election day. After warning its Conservative readership that "The greatest care should be exercised in preventing them [the books] from falling into the hands of our opponents", it emphasized that "the motto of the party be Register! Register! Register!" Moreover, the text never specifies that its Conservative readers should only register known Conservative voters: it simply advises them to register as many people as possible. This Conservative strategy reinforces the notion that Prime Minister Macdonald's franchise act fashioned an electorate of predominantly conservative and Conservative voters. By registering as many Canadians as possible to vote, the Conservatives, in Ontario at least, must have felt certain that more of those Canadians would vote Conservative rather than Liberal. If the Conservative party did not make such an assumption, its strategy would make no sense. See: LiberalConservative Union of Ontario, Handy Book on the Dominion Franchise Act, $2^{\text {nd }}$ ed. (Toronto: The Union, 1886), $1 ; 22$.

${ }^{139}$ For the returns of the 1887 and 1891 general elections, see: Beck, Pendulum of Power, 56; 71. Although the Liberals won the 1896 election, they only garnered 405,185 votes. Compare that with the 414,838 votes that the Conservatives received. See: Ibid., 86 . As the next chapter will discuss, the Liberals struck the Electoral Franchise Act from the Dominion's statute books in 1898. Consequently, later elections took place under different franchise law. 
conservative, it, at the very least, would become no more liberal. In this way, the Conservatives' Electoral Franchise Act - a document comprised of a mere sixty-five sections - had the potential to precipitate a reformation of the Canadian state. Whether it did so successfully, however, is a story for another day. ${ }^{140}$

Upon the passage of Prime Minister John A. Macdonald's Electoral Franchise Act in July of 1885 an unprecedented and seismic change took place in Canada's electoral history. Ever since the advent of representative government in Nova Scotia in 1758, the provinces had always governed Canadian legislative elections. Even after colonial union and the creation of the Dominion Parliament in 1867, provincial control of the franchise remained in force. With Prime Minister Macdonald's franchise legislation finally on the statute books, that tradition had finally ended. The Dominion now possessed a unified federal franchise of its own and the provincial legislatures no longer had the ability to affect federal elections by toying with their own provincial franchises. The last piece of Confederation's puzzle was finally in place, and only eighteen years late. While John A. Macdonald's Conservative Dominion government nobly wished to prevent such tampering for the sake of good governance, its desire for federal control of the Dominion franchise was not entirely virtuous in nature. With Liberal parties leading provincial legislatures across the country, it was in the federal Conservatives' best interests to bring governance over the Dominion franchise completely into the federal sphere. If they did

${ }^{140}$ Although an analysis of the successes and failures of the Electoral Franchise Act's participation in state formation deserves a paper in of itself, a few words may be included here. When it comes to reorienting political culture through franchise reform, Canada represents a particularly difficult challenge. Unlike other nations, Canada at this time had separate federal and provincial franchises. Considering the fact that the provincial franchises continued upon a liberalizing path, which resulted in expanded provincial electorates, such liberal changes would have balanced out conservative restrictions to the Dominion franchise. As a result, the potential that federal franchise reform would have affected a broader political culture would have been diminished. 
not, these Liberal governments could have used their control over franchise law to pass legislation that could potentially hurt the federal Conservatives' chances for re-election.

The Conservatives' choice to federalize the Dominion franchise had other partisan motivations behind it as well. Because they took control of federal franchise while possessing a Parliamentary majority, it fell upon the Conservative government, and upon Prime Minister Macdonald more specifically, to create the nation's voters' lists. In other words, the Prime Minister gained the power to appoint officers of his choosing to revise these voters' lists. Not only did that place several hundred prime patronage positions into the Conservatives' hands, it also allowed them to employ known Conservative sympathizers, such as Judge Edward Morgan, to select just who could or could not vote during a given federal election. While these revising barristers did not necessarily allow their partisan sentiments to trump their impartiality, the fact they had the federal government to thank for their appointments undoubtedly increased the potential for electoral corruption in the (Conservative) government's favour. Political expediency and partisanship therefore played as large a role as that of good governance when it came to the administrative sections of the Conservatives' Electoral Franchise Act. With regard to the variety of franchise the legislation actually instituted, however, political ideology played the leading role.

In the years following Confederation, every province of the Dominion except for Quebec had seen fit to expand the size of its electorate. With the Electoral Franchise Act of 1885 , the Conservatives ended such liberal-minded extensions of the Dominion franchise. By placing property and income qualifications on the federal franchise that handily eclipsed those of every province except Quebec, Prime Minister Macdonald 
effectively restricted the federal franchise. In reducing the size of Canada's federal electorate, and in using real property and personal wealth in particular to do so, the Conservatives followed Edmund Burke's conservative political philosophy to the letter. Moreover, the Conservatives' franchise act went beyond a mere ideological correspondence with traditional conservative principles. Following the precedent set by Benjamin Disraeli's Second Reform Act of 1867, the legislation also sought to better engrain those principles into the very fabric of the Canadian state itself. By restricting the federal franchise to an even wealthier group of Canadians than before, it seems that Prime Minister Macdonald hoped to form a federal electorate composed of proportionally more Conservative voters than Liberal voters. While such a project would have undoubtedly improved the Conservatives' chances for re-election, it also represented an attempted reorientation of the state's political culture. As the new franchise act bestowed citizenship upon a generally more conservative group of Canadians, it increased the potential that the body politic would also embrace further conservative legislation instituted by the Conservative party. Through this process - made possible by a master stroke of legislation that dextrously combined partisan advantage and philosophical projection - the possibility arose that the Canadian state would slowly undergo a reorientation toward a more conservative path. For eleven years, that potential existed at the federal level. Then, in 1896, under the proposition that the Conservatives' Electoral Franchise Act "should be repealed", Wilfrid Laurier's Liberal party took the federal election of that year. ${ }^{141}$ Canada would have a new Dominion franchise two years later.

${ }^{141}$ Liberal Party of Canada, Platform of the Liberal Party of Canada: Exemplified by Quotations, Tables and Arguments Based on Census and Trade Returns (Charlottetown: Geo. W. Gardiner, 1895), 6. 


\section{Chapter 4}

\section{"In no two cases...do you find the same franchise apply": The Franchise Act of 1898}

When Prime Minister Wilfrid Laurier rose to address the House of Commons on the evening of April 21, 1898, he hoped to rise above the petty bickering that had hitherto plagued his party's franchise bill. The legislation, known as Bill No. 16, or, the Franchise Act of 1898, had by that date stagnated in the House of Commons' committee stage for three full weeks. In that time, the committee of the whole had managed to pass a mere four sections of the twenty-six encompassed within the bill. ${ }^{1}$ Indeed, the Commons had already spent the better part of the day discussing section five alone. ${ }^{2}$ As the Conservatives did their best to stall the legislation - as the Liberals had done when the Conservatives tabled their franchise bill in 1885 - Members of Parliament from both sides of the House grew increasingly restless. Decorum began to suffer as a result. Before the Speaker recognized the prime minster, Member of Parliament for York, New Brunswick and former Conservative finance minister, George Eulas Foster, had the floor. Renowned for his strong oratory and general lack of tact, Foster levelled yet another bombastic assault against both the Liberals' bill and the Liberals themselves. ${ }^{3}$ Amid grand indictments that the legislation would "disenfranchise thousands of...citizens of this country, just as intelligent as [those] who sit in [the] House", Foster seemingly

\footnotetext{
${ }^{1}$ See: Canada, Bill. An Act to repeal the Electoral Franchise Act, and to further amend the Dominion Elections Act (Ottawa: S. E. Dawson, 1898).

${ }^{2}$ It took another twenty-six days for the Liberals' franchise bill to clear the House of Commons Committee stage. It passed its third reading on the evening of May 17, 1898. See: Canada, Official Report of the Debates of the House of Commons of the Dominion of Canada [Hansard], $3^{\text {rd }}$ session, $8^{\text {th }}$ Parliament, volume XLVII (Ottawa: S. E. Dawson, 1898), 17 May 1898, 5709.

${ }^{3}$ P. B. Waite, "Foster, Sir George Eulas," The Canadian Encyclopedia, $2^{\text {nd }}$ edition, vol. 3, ed. James H. Marsh (Edmonton: Hurtig, 1988), 830.
} 
attempted to discredit the bill with every pejorative term he could muster. ${ }^{4}$ In the course of doing so, he called the legislation everything from "unjust", "retrograde", and "immoral" to "a cheat" and "a fraud". 5 Reflecting the general tenor of the session itself, Foster's onslaught continued for over an hour. ${ }^{6}$ When the Prime Minister finally had the opportunity to speak, the tone of the House, however, changed considerably.

In contrast to Foster's extemporaneous oral attack, Prime Minister Laurier had chosen to prepare an eloquent, well-researched address for his colleagues "to lift this discussion to the level which it ought to occupy by reason of its importance." from lessons in British, American, and French history to a treatise on DominionProvincial relations, to a discourse on the tenets of classical liberalism itself, he attempted to rationalize his repeal of John A. Macdonald's Electoral Franchise Act to both the naysayers who resided in the opposing benches and, perhaps to a certain extent, the members of his own party who sat behind him. Without mincing his words, Laurier laid bare his own opinions about the franchise before the House. This held especially true with respect to the notion of universal manhood suffrage. Even when the Conservatives reformed the federal franchise in 1885, certain Liberal Members of Parliament had advocated the institution of manhood suffrage. In comparison with the Conservatives'

${ }_{5}^{4}$ Hansard, vol. XLVI, 21 April 1898, 4002.

${ }^{5}$ Ibid., 4001-4002.

${ }^{6}$ Foster's speech spans eleven pages in Hansard, from pages 3997 to 4008 . As with earlier editions of Hansard, each printed page was divided into two columns of text. By 1898, however, each of these columns was given its own page number. As such, Foster's speech would have only stretched five and a half pages in previous editions. If four full pages of Hansard roughly equates to one hour of speech as determined by using the same method employed to calculate the length of Edward Blake's exceptionally long speech in the previous chapter of this thesis - then Foster spoke for approximately one hour and twenty-two minutes.

${ }^{7}$ Hansard, vol. XLVI, 21 April 1898, 4008. 
franchise act, they viewed manhood suffrage as nothing short of a godsend. ${ }^{8}$ Notably, a younger Wilfrid Laurier was not amongst those Liberals. At the time, he made it abundantly clear that he did not favour manhood suffrage and that it would be a "tyranny" to impose it upon Canada. ${ }^{9}$ Now thirteen years later, the Prime Minister's views had not changed. In his address to the House that Thursday evening, Laurier announced that "Liberal of the Liberals that I am, I do not believe that the French nation acted wisely in 1848 when they gave the right of suffrage to every man, whether he was qualified or not. ${ }^{\prime 10}$ Nor did he single out the French republic as irresponsible. For Laurier, all nations that had extended the suffrage universally had "prostituted their franchise." Bl1 Because he "believe[d] that manhood suffrage is not the correct thing", he declared that he refused to impose it upon Canada. ${ }^{12}$ Disenfranchised Canadians would apparently have to keep waiting before they too could exercise the federal vote.

Prime Minister Laurier's Liberals had originally promised electoral reform in the election campaign of $1896 .{ }^{13}$ After a false start in 1897 , and five months of gruelling debate in 1898 , the Liberals' franchise legislation took effect. ${ }^{14}$ When it did, any Canadians who expected a restrictive Dominion franchise would have been mistaken. Although Prime Minister Laurier, through his rhetoric, might have endorsed restrictions upon the Dominion vote, the Liberal franchise act in the end established near-manhood suffrage throughout most of Canada. Disenfranchised Canadians would apparently not

\footnotetext{
${ }^{8}$ These Liberal Members of Parliament included Huron West, Ontario's Malcolm Colin Cameron, and Elgin West, Ontario's George Elliott Casey. See: Ibid., vol. XVIII, 17 April 1885, 1140; 21 April $1885,1265$.

${ }^{9}$ Ibid., vol. XVIII, 17 April 1885, 1169.

${ }^{10}$ Ibid., vol. XLVI, 21 April 1898, 4010.

${ }^{11} \mathrm{Ibid}, 4011$.

${ }^{12} \mathrm{Ibid}$.

${ }^{13}$ Again, see: Liberal Party of Canada, 6.

${ }^{14}$ The Franchise Act Repeal Bill officially took effect June 13, 1898. See: Elections Canada, 52.
} 
have to wait very long to receive the federal vote after all. Why then did the Liberal party enact what basically amounted to manhood suffrage when its leader so fervently spoke in opposition to it? This chapter will attempt to answer this question through a closer examination of the federal Franchise Act of 1898 and the debates that surrounded it. Once again, however, an analysis of the legislation itself must first ensue.

When compared with the Conservatives' Electoral Franchise Act of 1885, the Liberals' franchise act appears as simplicity itself. Instead of a long series of confusing qualifications and exclusions, one easy to understand goal lay at its core: to repeal the franchise act introduced in 1885. In nullifying John A. Macdonald's franchise reform, the provincial legislatures would once again govern the federal franchise as they did in the years following Confederation. ${ }^{15}$ Yet, such a shift did not by any means signify a reversion to the franchises imposed upon Canadians during the first general election in 1867. While the Dominion government may have once again employed the provincial franchises for federal elections, the new franchise act did not give free reign to the provinces to enact whatever franchises they desired. For example, section six of the law provided that it would not disqualify any person on the basis of his "profession, calling, employment, or occupation" or whether he belonged "to any other class of persons, although possessed of the qualifications generally required by the provincial law, are by such law declared to be disqualified by reason of their belonging to that class." ${ }^{.16}$ While the legislation never specifically indicates to whom a "class of persons" refers, it is clear that the Laurier government only wished to narrowly embrace the various property and

\footnotetext{
15 "The Franchise Act, 1898" in Arnott J. Magurn, ed, The Parliamentary Guide and Work of General Reference 1898-1899 (Winnipeg: The Manitoba Free Press Company, 1898), 320. See sections 3 and 5 in particular.

${ }^{16}$ Ibid., 321. See section 6, particularly paragraphs 'c' and 'd'.
} 
income qualifications established by the provinces to create the Dominion franchise.

This meant that many Canadians who had been barred from the vote because of their race - such as Canadians of Chinese or Japanese descent in British Columbia - would receive the federal vote for the first time. ${ }^{17}$ Yet, somewhat strangely, the new legislation did not eliminate all forms of racial discrimination from the federal franchise.

Although section six of the act seems to encompass Aboriginal Canadians in the same way as Chinese Canadians, Canadians of First Nations descent could no longer vote federally after $1898 .^{18}$ The legislation provides no clear-cut explanation for such mass disenfranchisement. While the act stipulates that no person "in whole or in part...receiving charitable support" should exercise the franchise, which perhaps also refers to First Nations people living on reserves, not all members of the First Nations lived on reserve. ${ }^{19}$ As such, only one possible explanation presents itself: that the Laurier government did not choose to view Aboriginal Canadians as a distinct "class of persons". ${ }^{20}$ No matter the reasoning behind it, the Liberals in the end reversed one of the

${ }^{17}$ Section eight of British Columbia's Provincial Elections Act of 1888 - the provincial legislation in effect in 1898 - states that "No Chinaman, Japanese, or Indian shall have his name placed on the Register of Voters for any Electoral District, or be entitled to vote at any election. Any Collector of Votes who shall insert the name of any Chinaman, Japanese, or Indian in any such register, shall, upon summary conviction thereof before any Justice of the Peace, be liable to a penalty not exceeding fifty dollars." See: British Columbia, The Revised Statutes of British Columbia 1897, vol. I (Victoria: Richard Wolfenden, Printer to the Queen's Most Excellent Majesty, 1897), 689. See also: Elections Canada, 52.

${ }^{18}$ Malcolm Montgomery painstakingly attempts to highlight the federal disenfranchisement of Aboriginal Canadians by the Laurier government in "The Six Nations Indians and the Macdonald Franchise". See: Montgomery in Ontario History, 13; 25.

19 "The Franchise Act, 1898" in Magurn, ed., 321. See section 6, subsection 4.

${ }^{20}$ A History of the Vote in Canada also advances this argument. See: Elections Canada, 52-53. Montgomery argues that the Liberals wished to disenfranchise Canadians of First Nations descent because they "had committed the crime of not voting the right way". For example, primarily Aboriginal ridings such as South Brant in Ontario had refused to return Liberal candidates during the federal election of 1896. Montgomery concludes that "The punishment that the Indians received was that of being deprived of the right to vote for sixty-two years." (First Nations Canadians would only again receive the vote in $\mathbf{1 9 6 0}$ "when Parliament enabled the Indians of Canada living on reserves to vote in Federal elections".) Montgomery unfortunately never reconciles the stipulation within 1898's franchise act that barred 
very few socially-progressive elements incorporated into the suffrage legislation the Conservatives passed thirteen years earlier. This decision is quite odd considering the various provincial franchises they had chosen to adopt.

Just as the new Dominion franchise would not precisely mirror the franchise of 1867, the provincial franchises had themselves changed considerably since Confederation as well. Even before John A. Macdonald altered the Dominion franchise for the first time, certain provinces had already undertaken a process of expanding their franchises. The process had not stopped there either. As the end of the century drew nearer, manhood suffrage slowly became the norm for the majority of Canada's provinces. Prince Edward Island and British Columbia, as mentioned earlier, had enacted nearmanhood suffrage upon their entry into the Confederation. Their legislators had done nothing to change that fact between 1885 and 1898 . In the meantime, Ontario and Manitoba had seen fit to abolish their property and income qualifications and replace them with near-manhood suffrage as well. ${ }^{21}$ As a result, four of the seven provinces including Canada's most populous province, Ontario - had by 1898 instituted remarkably inclusive franchises at the provincial level. Only Quebec, New Brunswick, and Nova

discrimination against Canadians based upon their "class" and the disenfranchisement of Aboriginal Canadians. See: Montgomery in Ontario History, 25; 13.

${ }^{21}$ Elections Canada, 54. According to The Ontario Election Act, 1892, any "male person of the full age of twenty-one years [and] a subject of Her Majesty by birth or naturalization" who had resided in Ontario for at least nine months - with the exception of "unenfranchised Indians", who still had to meet a $\$ 200$ urban and $\$ 100$ rural property qualification - automatically qualified for the provincial vote. See: Ontario, Statutes of the Province of Ontario, 55 Victoria, 1892 (Toronto: Lud K. Cameron, 1892), 15-17. Manitoba's Election Act of 1891 similarly enfranchised all male citizens over the age of twenty-one who were, "at the date of the issue of the proclamation appointing the Registration Clerk, and has been for one month immediately prior to said date a resident of and domiciled within the said Electoral Division, and has been for six months immediately prior to said date a resident of and domiciled within the Province." See: Manitoba, Acts of the Legislature of the Province of Manitoba passed in the session held in the FiftyFourth Year of The Reign of Her Majesty Queen Victoria, being the Fourth Session of the Seventh Legislature, vol. I (Winnipeg: David Philip, Queen's Printer, 1891), 148. Refer to section twelve of the statute in particular. 
Scotia had not lowered their qualifications for enfranchisement since $1885 .{ }^{22}$ That said, both New Brunswick and Nova Scotia maintained less restrictive franchises than the Electoral Franchise Act of $1885 .{ }^{23}$ Quebec now represented the only province where the repeal of the Conservatives' franchise legislation actually reduced the electorate in any way: now rural Quebecers would have to own at least $\$ 200$ worth of real property instead of $\$ 150$ to cast a federal ballot. ${ }^{24}$ Even taking this modest restriction into account, there is no mistaking the overall effect the Liberals' franchise act had on the federal electorate. Because it introduced significantly less restrictive legislation in six of the seven provinces, and that it, for the most part, forbade disenfranchisement on the basis of traits such as occupation and race, the size of the federal electorate undoubtedly grew.

${ }^{22}$ According to the Quebec Election Act of 1895, male citizens over the age of twenty-ome still had to own "real property estimated, according to the valuation roll in force, at a sum of at least three hundred dollars in real value, in any city municipality entitled to return one or more members to the Legislative Assembly, or two hundred dollars in real value or twenty dollars in annual value in any other municipality" or pay "an annual rent, for real property, of at least thirty dollars in any city municipality entitled to return one or more members to the Legislative Assembly, or at least twenty dollars in any other municipality; provided such real property be estimated, according to such valuation roll, in real value at, at least, three hundred dollars in any city municipality entitled to return one or more members to the Legislative Assembly, or two hundred dollars in any other municipality". See: Quebec, Statutes of the Province of Quebec passed in the Fifty Ninth Year of the Reign of Her Majesty Queen Victoria and in the Fifth Session of the Eighth Legislature (Quebec: Charles François Langlois, 1895), 39. Refer to section nine of the statute especially. The New Brunswick Elections Act of 1889, on the other hand, required male citizens over the age of twenty-one to possess "real estate to the value of one hundred dollars, or personal property, or real and personal property together to the value of four hundred dollars in any electoral district" to qualify for the provincial vote. New Brunswick would not abolish its property and income qualifications for the provincial franchise until 1916. See: New Brunswick, Acts of the General Assembly of Her Majesty's Province of New Brunswick (Fredericton: G. E. Fenety, 1889), 22-23. See also: Elections Canada, 56. Like New Brunswick, Nova Scotia had also instituted new franchise legislation in 1889. Those who wished to receive a ballot, however, still needed to own "real property to the value of one hundred and fifty dollars, or, in respect of personal property, or of personal property and real property together, to the value of three hundred dollars... [or] Was, at the time of the last assessment, a bona fide yearly tenant of real property of the value of one hundred and fifty dollars..." Nova Scotians would have to wait even longer - until 1920 - to see property and income qualifications eliminated from their franchise. See: Nova Scotia, The Revised Statutes of Nova Scotia, 1900 (Halifax: Queen's Printer, 1900), 22 (particularly section three).

${ }^{23}$ Compare the above qualifications for New Brunswick and Nova Scotia with the federal Electoral Franchise Act of $1885^{\prime}$ 's $\$ 300$ city property qualification, $\$ 200$ town property qualification, $\$ 150$ rural property qualification, and $\$ 300$ income qualification.

${ }^{24}$ Elections Canada, 56. 
With respect to the extent of such growth in democratic participation, however, once again no entirely accurate means of determination exists. As mentioned earlier, the general unreliability of nineteenth-century election statistics and census returns do not sustain any sort of precise measurement of democratic activity. According to Norman Ward, the size of the electorate increased by 16.8 percent between the Dominion elections of 1891 and $1900 .{ }^{25} \mathrm{He}$, along with most other scholars on the subject, attributes this growth to the passage of the Franchise Act of $1898 .{ }^{26}$ Yet, as suggested by the preceding chapter, one should probably take Ward's statistics with a grain of salt. This is especially true considering electoral statistics within $A$ History of the Vote in Canada show a 190,926 decrease in the number of names on Dominion voters' lists between the federal election in 1896 and the federal election in $1900 .{ }^{27}$ Once again, a discussion as to who precisely received the federal vote offers the best method of determining the inclusivity of the new Dominion franchise.

As mentioned in chapter three, the Electoral Franchise Act of 1885 excluded two groups of Canadians from the franchise in particular: women, and low-income labouring Canadians. Although the women's suffrage movement had begun to gain momentum by 1898 , no Canadian province had yet sought to enfranchise its female inhabitants. ${ }^{28}$ The Franchise Act of 1898 had much more positive results for labouring Canadians, however. After weathering the punishing economic depression of the early-to-mid 1890s, Canadian

\footnotetext{
${ }^{25}$ Ward, 221, 225.

${ }^{26} \mathrm{Ibid}$., 225. See also: Elections Canada, 56.

${ }^{27}$ Elections Canada, 138. According to Table 1, Dominion voters' lists had 1,358,328 names for the 1896 federal election. Compare that number with 1,167,402 names for the 1900 election.

${ }^{28}$ Manitoba was the first province to grant the franchise to women when it did so on January 28 , 1916. The provinces of Saskatchewan and Alberta soon followed, respectively, in March and April of the same year. See: Cleverdon, 2.
} 
workers had started to reorganize themselves by $1898 .{ }^{29}$ The new trade unions that emerged once again placed an expansion of the franchise upon their list of demands. ${ }^{30}$ The Franchise Act of 1898 seems to have met this labour request. Because of the general rejection of property and income franchise qualifications within most provinces, the majority of labourers who remained disenfranchised in 1885 would have received the suffrage in 1898. Of course, one cannot offer exact numbers with respect to the scope of this enfranchisement. Nevertheless, labourers, and, more specifically, unskilled labourers, had represented the largest group of male Canadians before 1898 that still did not possess the federal franchise. ${ }^{31}$ As such, the Liberals' Franchise Act would have bestowed the federal vote upon most male Canadians. Despite Prime Minister Laurier's apparently conservative remarks to the House of Commons, he and his party argued that such an expansive, provincially-controlled franchise represented the best legislation for the Canadian nation.

As the Conservatives did in 1885, the Liberals employed the argument of good governance to preface their franchise reform. According to their campaign literature of 1896, the Electoral Franchise Act had simply cost the country too much money. The

\footnotetext{
${ }^{29}$ The depression of the 1890 s hit both Canadian labourers and their trade unions hard. As Bryan Palmer relates, "All unions avoided confrontation in these depression-ridden years, and some internationals, like the Molders', suffered serious setbacks in the face of a virulent capitalist offensive in 1890-92." When the nation's economy began to right itself through 1897 and 1898, so did Canada's trade unions. See: Palmer, Working Class Experience, 168.

${ }^{30}$ Canadian working-class and labour historians agree that "an explosion of [labour] organization" occurred between the years of 1898 and 1902. In fact, Bryan Palmer cites that these years saw a " 250 per cent increase in the number of chartered international unions in Canada." See: Desmond Morton, Working People, $5^{\text {th }}$ ed. (Montreal and Kingston: McGill-Queen's University Press, 2007), 71; Palmer, Working Class Experience, 169.

${ }^{31}$ By virtue of the fact that no Canadian women could vote federally, women still represented the largest identifiable group of disenfranchised Canadians. That would not change until 1918, when Prime Minister Robert Borden's Conservative government finally allowed a substantial portion of Canadian women the vote (those who met the property qualifications of the province in which they resided). See: Elections Canada, 63.
} 
federal franchise offended their liberal frugality. Estimates varied regarding the amount it drew from the federal coffers. On the one hand, Solicitor General Charles Fitzpatrick the Liberal Member of Parliament who tabled the franchise bill in the House of Commons - claimed that the four revisions of Dominion's voters' lists that took place between 1885 and 1895 had cost the federal government at minimum $\$ 1,154,000$. If one also included "cost to individuals, to the members, to those who take part in the administration of public affairs", Fitzpatrick approximated the final tally to be closer to $\$ 1,500,000 .{ }^{32}$ On the other hand, Fitzpatrick's Liberal colleague, Peter Macdonald, member for Huron East, Ontario, provided a somewhat more conservative assessment. Breaking down the cost of each revision, he asserted that the Electoral Franchise Act of 1885 had instead cost the Dominion an additional $\$ 1,124,729 .{ }^{33}$ Considering that the Dominion's entire defence budget for the previous year totalled $\$ 1,800,000$, either of these figures was rather sizeable for the time. ${ }^{34}$ With the provinces already spending thousands of dollars to revise their own voters' lists, the Liberals argued that spending thousands more dollars to fashion similar lists in Ottawa represented an exercise in wastefulness "out of all proportion to the benefits realized". ${ }^{35}$ By repealing the Electoral

\footnotetext{
${ }^{32}$ Hansard, vol. XLVI, 22 March 1898, 2273.

${ }^{33}$ During his speech, Macdonald provided a breakdown of his figures. According to him, the 1886 revision of the Dominion voters' list cost $\$ 416,000$, the 1889 revision cost $\$ 238,426$, the 1891 revision cost $\$ 226,749$, and the $1894-1895$ revision cost $\$ 243,554$. See: Ibid., 2302. During the same debates, the Conservative party provided its own estimated cost of the Electoral Franchise Act of 1885. Citing the Auditor General's findings, Conservative member for Stanstead, Quebec, Alvin Head Moore, reported that Conservatives' franchise legislation cost only $\$ 826,782.97$. Moore was even more specific: he informed the Commons that the 1886 revision cost $\$ 159,882.85$, that the 1887 revision cost $\$ 193,858.44$, that the 1889 revision cost $\$ 233,078.35$, and the 1894 revision cost $\$ 239,963.33$. Noticeably, not only did Macdonald and Moore not agree upon the cost of each revision, but they did not even agree upon the years those revisions took place. See: Hansard, vol. XLVI, 25 March 1898, 2603. A History of the Vote in Canada cites that, during its thirteen-year existence on the statute books, the Electoral Franchise Act of 1885 cost the nation approximately $\$ 1,500,000$. See: Elections Canada, 52.

${ }^{34}$ See: Buckley and Urquhart, eds., 201.

${ }^{35}$ Hansard, vol. XLVI, 22 March 1898, 2273.
} 
Franchise Act, the federal government claimed that it would free a substantial sum of money for more important projects, an objective rooted in the party's long dedication to low-cost government.

Unsurprisingly, Liberals outside the House of Commons joined their Parliamentary brethren in denouncing the cost of the Electoral Franchise Act of 1885. As W. F. Luxton, editor of the Liberal Manitoba Free Press, disparagingly wrote, the cost of administering the Conservatives' legislation was undoubtedly its most objectionable feature. Echoing the language hurled across the floor of the House of Commons, Luxton bemoaned the fact that "Each revision [of the voters' lists] has cost the country its hundreds of thousands, and hundreds of thousands more came out of the pocket of members and candidates. ${ }^{36}$ If only Liberals condemned the wastefulness of the 1885 franchise in this way, their opponents might have dismissed Liberal arguments as mere partisan gamesmanship. Yet, even Conservatives admitted that the Electoral Franchise Act represented too large a drain on the federal coffers. For example, Thomas $S$. Sproule, member for Grey County East, Ontario, conceded that "the old franchise is an expensive one..." ${ }^{37}$ The Conservative member for Lunenberg, Nova Scotia, Charles Edwin Kaulbach, went further than his Ontarian ally: he called the franchise act of 1885 both "expensive" and "cumbersome". ${ }^{38}$ Even newspapers that staunchly defended the Conservatives' franchise legislation in 1885, such as The Brandon Mail, published editorials stating that "No one can truthfully say the present Franchise Act is a model of

\footnotetext{
36 "The Franchise Bill", Manitoba Daily Free Press, 29 April 1898, 2.

${ }^{37}$ Hansard, vol. XLVI, 22 March 1898, 2301.

${ }^{38}$ Ibid., 1 April 1898, 2931.
} 
perfection - in fact it is very cumbersome and defective."39 These sorts of admissions allowed Liberal Canadians to posit that "the Conservative party itself never felt very much enamored of the franchise law which it created."

With Conservatives disparaging their own party's legislation, the Liberals' argument that they had decided to repeal the existing federal franchise legislation on the basis of good governance gained even more credence. Not only would the new franchise reportedly save the Dominion "hundreds of thousands", it would also more or less satisfy general public opinion concerning the Dominion franchise. This is especially true of working-class Canadians in 1898. In the Canadian Trades and Labor Congress of that year, members once again endorsed franchise extension as part of the new labour platform for the twentieth century. ${ }^{41}$ The fact that the Canadian organized labour at this time had a strong "affinity with the Laurier Liberals" may have also made this platform more evident to the presiding government. ${ }^{42}$ Canadians from all walks of political life had therefore ostensibly demanded a more frugal (and, perhaps, a more inclusive) federal franchise law. As a good democratic government should, the Liberals seemed to have listened to their constituents and used their franchise repeal act to fix the apparent problem. Aside from these financial and attitudinal considerations, the Liberals

39 "At Ottawa", The Brandon Mail, 11 March 1897, 4. By 1897, The Brandon Mail had detached itself from the Conservative party in favour of a strictly independent political outlook (although it still maintained its attachment to Manitoba's farmers). Such a political shift may in part explain the Mail's newfound opinion of the Electoral Franchise Act of 1885. Even so, in the same editorial, the Mail criticized the Liberals' legislation as inadequate as well.

${ }^{40}$ Victoria Daily British Colonist [editorial], 26 March 1898, 4.

${ }^{41}$ Palmer, Working Class Experience, 177.

${ }^{42}$ Ibid. As Bryan Palmer perceptively contends, this Liberal "affinity" may have ensured that labour's "impact in the political realm would not be felt until a few years later." While sympathy with the Liberals may have brought a certain amount of attention to the labour platform within the Liberal party indeed, Prime Minister Laurier created the federal Department of Labour in 1900 - it also would have most likely diminished any political pressure exerted upon Prime Minister Laurier and his government by labour supporters. See: Ibid. 
maintained that their franchise reform participated in good governance for one other reason as well. This motivation hearkens back to the infamous revising barrister clause of the Conservatives' franchise legislation.

Although the Liberals had many reasons to dislike the Electoral Franchise Act of 1885 , the fact that it allowed the Conservative government to directly appoint revising officers had angered them perhaps more than anything else. Liberals both inside and outside the House of Commons contended that such a conflict of interest would invariably lead to electoral mismanagement in favour of the Conservative party. Now after thirteen years of observing the 1885 act in operation, the Liberals had seen enough to claim that they were correct in their predictions. As Prime Minister Laurier himself pointedly described it in 1898, the Conservatives' franchise "was an abuse of power, whereby the revision of the lists was placed in the hands of henchmen of the Administration. ${ }^{, 43}$ Of course, the Liberals could have easily exploited the franchise act themselves by appointing their own Liberal-minded revising barristers. Instead, the Prime Minister had apparently decided that his party should adopt and promote a nobler approach to electoral politics. To that end, he declared to Parliament that "What we [as Liberals] want is a system that has in it least of the partisan spirit, and I submit that there is no system we can devise that will possess less of a partisan spirit as regards the preparation of the lists than the system which prevails in Ontario, Quebec, Nova Scotia and New Brunswick, where the lists are prepared by the municipal authorities." ${ }^{44}$ Thus, a repeal of the Electoral Franchise Act and an adoption of the provincial voters' lists would

\footnotetext{
${ }^{43}$ Ibid., 2289. At the level of party competition, Laurier also revealed that "[d]uring the last twenty years we [the federal Liberals] have suffered too much at the hands of revising officers..." See: Ibid., 2288.

${ }^{44}$ Hansard, vol. XLVII, 26 April 1898, 4313.
} 
apparently ensure that the Dominion would carry out its elections in a more neutral and objective manner. The liberal ideal of egalitarianism would therefore be upheld. Liberal Members of Parliament such as Colchester, Nova Scotia's Firman McClure commended themselves and their party's legislation for that reason at any rate. ${ }^{45}$ Nonetheless, the Franchise Act of 1898 was perhaps not as impartial as the Liberals let on.

Much like the motivation behind the Electoral Franchise Act of 1885, good governance coincided with political partisanship quite readily with respect to the Liberals' franchise legislation. True, the Dominion government may not have had the power to directly govern the federal franchise any longer. Even so, such a loss of control did not necessarily represent a disadvantage when it came to the Liberals' chances for reelection. ${ }^{46}$ During the 1898 session of Parliament, all provinces with the exception of British Columbia had returned the Liberals to form their provincial governments. ${ }^{47}$ Of course, the fact that the Liberals held power in the provinces did not necessarily translate to better treatment or increased cooperation for Prime Minister Laurier and his Dominion government. Ever since Confederation, however, the federal Liberals had billed themselves as the party of provincial rights and autonomy; for decades, they had

\footnotetext{
${ }^{45}$ Ibid., 4401.

${ }^{46}$ Norman Ward forwards a similar argument in The Canadian House of Commons: Representation. See: Ward, 224.

${ }^{47}$ British Columbia's Charles Augustus Semlin was this sole Conservative premier. Born near Barrie, Ontario in 1836, Semlin occupied himself with numerous jobs - from teacher to miner to rancher to hotel owner - before entering politics in British Columbia in 1871. After representing the constituency of Yale for a number of years, Semlin became the leader of the opposition in 1894. Interestingly, thenpremier John Herbert Turner was, like Semlin, a staunch conservative as well. After Turner's government failed to win a clear majority in the 1898 provincial election, British Columbia's Lieutenant-Governor dissolved Turner's government and eventually called upon Semlin to form the new ministry. Unfortunately for Semlin, his premiership only lasted until 1900, a mere eighteen months. See: Jeremy Mouat, "Semlin, Charles Augustus", Dictionary of Canadian Biography, vol. XV, ed. Ramsay Cook (Toronto: University of Toronto Press, 2005), 915-917.
} 
advocated for increased powers for the provincial governments. ${ }^{48}$ Moreover, Laurier's own cabinet reflected this ideal: it was filled with provincial rights champions (and former provincial premiers) Oliver Mowat, Andrew Blair, and William Fielding. ${ }^{49}$ It would have consequently been in the provinces' best interests to have the federal Liberals retain the reins of Parliament.

Conveniently, through the Franchise Act of 1898, the federal Liberals provided the provinces with the perfect way of protecting these interests: they could simply alter their own franchises to favour the federal Liberals come election day. In 1885, the Conservatives feared such alterations. They had in part reformed Canada's federal franchise legislation to prevent such underhanded schemes from taking place at the provincial level. Laurier's Liberals had now purposefully reopened the door to such "vic[i]ous" electoral designs, much to the chagrin of Conservative leader Sir Charles Tupper. ${ }^{50}$ And if the Liberal provincial governments did not go so far as to alter their franchise laws in favour of the federal party, Prime Minister Laurier could, at the very

${ }^{48}$ This Liberal belief will be discussed in more detail later in this chapter.

${ }^{49}$ Throughout their time in provincial parliament as leaders of their respective provinces' Liberal parties, Ontario's Mowat, New Brunswick's Blair, and Nova Scotia's Fielding worked tirelessly to wrestle power from the Dominion government and to have that power bestowed upon the provincial governments. Prime Minister John A. Macdonald, the dedicated centralist, viewed Mowat especially as his principal adversary with regard to the provincial rights movement.

${ }^{50}$ In a March 26, 1898 written response to Mr. Wellington Boulter of Picton, Ontario - a Conservative supporter, one would assume - Tupper very clearly outlined his complaint: "After the experience that we have had of the abuse of the franchise act in the hands of the local legislatures I need not say how much we dread seeing that vicous [sic] system fastened upon the country." See: LAC, Sir Charles Tupper fonds, MG 26-F, "Political papers" series, reel C3208, page 8709, letter from Sir Charles Tupper to Wellington Boulter, 26 March 1898. For similar sentiments expressed to the House of Commons, see: Hansard, vol. XLVI, 22 March 1898, 2274-2277. In the decades following Confederation, Tupper spoke for Nova Scotia in John A. Macdonald's federal Cabinet. After Mackenzie Bowell's short-lived ministry of 1895, Tupper became Prime Minister of Canada on February 4, 1896. He soon lost to Wilfrid Laurier's Liberal party in the federal election of that year. Courageous, combative, partisan, and sometimes pompous, Tupper was certainly a thorn in Laurier's side as leader of the opposition during Laurier's first term as prime minister. Tupper would subsequently lose his own seat in the federal election of 1900 and step down as Conservative leader as a result. See: Buckner in Dictionary of Canadian Biography, vol. XIV, 1017-1023. 
least, expect provincial franchise reforms to avoid damaging his chances for re-election.

For this reason, vociferous Conservative Member of Parliament, George Foster, condemned the Liberals' franchise legislation. Because the post of revising barrister represented such a plum patronage position, Foster believed that Liberal provincial governments would appoint Liberals to revise their voters' lists. ${ }^{51}$ Although the Liberals may have in part based their legislation "on the principle of being freed from the activity of a partisan government in making up their lists", Foster in the end concluded that "if it [the Liberals' bill] became law, we would be landed in exactly the same predicament [as with the Electoral Franchise Act of 1885]. ${ }^{.52}$ Although Prime Minister Laurier promoted his party's franchise act as a non-partisan measure, it appears that the act participated in the same partisan game as the legislation it repealed. Aside from good governance, however, the Liberals had another set of arguments to counter Conservative accusations of partisanship. These arguments revolved around political and party ideology.

Ever since their inception as the Reform Party of Canada, the Liberals had billed themselves as the party of small government. This shared belief stemmed from classical liberal values concerning individualism, derived largely from the seventeenth-century writings of English political philosopher John Locke. Locke maintained that the government should intrude into an individual's life only to the extent that it might protect the individual and those things fundamental to the enjoyment of life. ${ }^{53}$ Otherwise, the

${ }^{51}$ Hansard, vol. XLVIII, 26 April 1898, 4301-4302.

${ }^{52} \mathrm{Ibid}$., 4304. Despite his dogged defence of his party's franchise legislation in 1885, Foster here seems to admit that the Conservatives' legislation was indeed, after all, a highly partisan measure.

${ }^{53}$ In 1689, John Locke published his Two Treatises of Government. In the second of these treatises, he comments upon the reasons why people come together to form communities. Unlike one of Locke's close predecessors, Thomas Hobbes (when writing 1651's Leviathan), Locke did not view the "State all Men are naturally in" as "a war... of every man against every man". Instead, Locke saw humanity's natural state as one where an individual is beholden to no one else, but must still act in 
government should not attempt to infringe upon or regulate the actions of individuals;

they should instead be free to do whatever they wish as long as their actions do not undermine or attack another person's life, liberty, or property. Later liberal philosophers reiterated the very same sentiments throughout the eighteenth and nineteenth centuries. ${ }^{54}$ For example, John Stuart Mill adamantly defended the necessity for small central governments and limited government interference in people's lives in his famous 1859 essay entitled On Liberty. According to Mill, "The objection to government interference, when it is not such as to involve infringement of liberty, may be of three kinds." 55 Alongside his belief that it is a "great evil [to add] unnecessarily to [the government's] power", he argued that individuals better understand their own business because they have an interest in it and that localities can better account for their own peculiar circumstances than a central government. ${ }^{56}$ Through his widely-read essay, Mill

accordance with divine reason. Locke therefore chose to reclassify Hobbes's state of nature as "the State of War". For Locke, this state of war "is one great reason of Mens putting themselves into Society". To mutually protect and preserve their "Lives, Liberties, and Estates", individuals choose to enter into a social contract with one another and create a political community or commonwealth headed by some form of central government or sovereign. In doing so, however, the sovereign does not receive unquestionable, absolutist control over the commonwealth (as Hobbes advocated). Alternatively, Locke encouraged strict limitations upon the sovereign's power. If the sovereign begins to act arbitrarily, without the consent of the people, or starts to establish new legislation or taxes without popular approval, Locke argues that the social contract is broken and the people may consequently dissolve the government. From this point of view, an increase in local power makes sense: with a closer proximity to their electors, local governments apparently have a better chance of attaining the popular assent necessary to uphold the social contract. See: Thomas Hobbes, Leviathan, ed. Edwin Curley (Indianapolis and Cambridge: Hackett, 1994), 76; 110-118. See also: John Locke, Two Treatises of Government, $2^{\text {nd }}$ ed. (Cambridge: Cambridge University Press, 1967), 287; $296 ; 300 ; 368-369 ; 424-428$ (emphasis in text).

${ }^{54}$ In his study of Democracy in America, French liberal scholar Alexis de Tocqueville also believed that nations must avoid "the evil that extreme centralization may produce". Presaging Michel Foucault's writings on the notion of governmentality, de Tocqueville argued that a strong central government - one that constantly interferes in individuals' lives - "daily makes the exercise of free choice less useful and rarer, restricts the activity of free will within a narrower compass, and little by little robs each citizen of the proper use of his own faculties." In other words, de Tocqueville also recognized strong centralized popularly elected governments as potentially diminishing the liberties enjoyed by a nation's citizenry. See: Tocqueville, 692. 101.

${ }^{55}$ John Stuart Mill, On Liberty, ed. David Spitz (New York and London: W. W. Norton, 1975),

$$
{ }^{56} \text { Mill, On Liberty, 101-102. }
$$


consequently reaffirmed for nineteenth-century western liberals the belief in small government for the sake of individual liberty. ${ }^{57}$

Echoing the words of John Stuart Mill, Liberals both inside and outside the House of Commons claimed that in the Canadian context the provincial legislatures found themselves in a better position to fashion the nation's franchise than the Dominion government. As Prime Minister Laurier himself declared to his Parliamentary colleagues in his first speech on the subject in 1898 , "the experience of all countries, governed by parliamentary institutions such as our own, shows us that the extension or the restriction of all franchises is a question which depends largely upon the conditions of the different communities where the franchises apply. It is a question of education, of customs, of circumstances; and in no two cases hardly do you find the same franchise apply." Because of Canada's regional diversity, Laurier believed that one universal piece of franchise legislation - like the one imposed upon the country by the Conservatives in 1885 - could not fully satisfy Canadians.

As the Prime Minister later explained, the re-adoption of the provincial franchise reportedly solved this problem by allowing each local legislature to determine the franchise that best suited its local population. For example, as Laurier related, "If the province of Ontario desires to have manhood suffrage, well and good; let them elect their legislature upon manhood suffrage. We in the province of Quebec will suffer nothing by it. But we in the province in Quebec believe that manhood suffrage is not the correct

\footnotetext{
${ }^{57}$ As a budding politician, Laurier resonated Mill's notions of small government in his famous exegesis of June 26, 1877 on the topic of political liberalism. To paraphrase Laurier, liberalism's belief in small government specifically combats the abuses of traditional political institutions, such as those committed by the most centralized government of them all: the absolute monarchy. See: Sir Wilfrid Laurier, Discours a L'Étranger et au Canada (Montreal: Librairie Beauchemin, 1909), 82-108 (and page 90 especially).

${ }^{58}$ Hansard, vol. XLVI, 22 March 1898, 2282.
} 
thing. If, then, we believe it is not best, why in the name of everything that is just should it be imposed upon us by this Parliament? ${ }^{39}$ By following liberal ideology in allowing a locally-controlled federal suffrage, the Liberals underscored their traditional belief that the provinces could better account for the nation's regional diversity. Instead of forcing Canadians to accept a procrustean universal piece of franchise legislation, they believed as they had for decades now - that each province could more effectively satisfy the desires of their populations with regard to franchise law. ${ }^{60}$ As Prime Minister Laurier implied, anything else would represent an imposition of an overgrown centralized government upon the citizens of the country. That being said, the liberal ideology that underpinned the Franchise Act of 1898 did not solely dwell within the legislation's diffusion of authority over the Dominion franchise. One can find it permeating the act's radical expansion of the electorate as well.

The advocates of classical liberal philosophy, since the mid-eighteenth century, had campaigned for a broad electorate. Rejecting the notion that only real property should grant the individual full political citizenship, classical liberals, from Montesquieu to John Stuart Mill, argued that self-sufficient male persons (and even self-sufficient female persons, in the case of Mill) should have the right to participate in state governance by means of the franchise. ${ }^{61}$ Closer to home, one William Trant of Regina, Northwest Territory expressed the same sentiments in his letter of April 10, 1897 to

${ }^{59}$ Ibid., 21 April 1898, 4011.

${ }^{60}$ In an 1883 letter to Edward Blake (his then party leader), Laurier had expressed the very same ideological sentiments concerning the suffrage. As he asked Blake: "And now both as a question of expediency \& principle, do you not think that the question of the franchise right to be left with the provinces, \& that we are right to fight it in that line." See: LAC, Edward Blake fonds, MG27-ID2, "Canadian political correspondence" series, reel M240, file 20, letter from Wilfrid Laurier to Edward Blake, 10 December 1883.

${ }^{61}$ For more on Montesquieu's and Mill's philosophies regarding the franchise, refer to the second chapter of this document. 
Prime Minister Laurier when he wrote that "Indeed I hold that according to true Liberalism every man who is not morally or physically incapable has a clear right to the franchise. $" 62$ By reforming the federal franchise to include most of those Canadians disenfranchised by the Franchise Act of 1885, Prime Minister Laurier's Liberals appear to have followed this classical liberal view of the suffrage. Even so, one must also remember that the Liberals' franchise legislation did not introduce manhood suffrage across the whole of Canada.

Although classical liberals such as Montesquieu and Mill desired that all male inhabitants should have access to the franchise, they also believed that the state should withhold the franchise from individuals who had demonstrated that they could not exercise it properly. Whether because of a supposed lack of intelligence or an inability to provide for oneself and one's family, these liberal philosophers felt that certain people simply should not have the vote. As Prime Minister Laurier explained to the House of Commons, even Great Britain's foremost Liberal politicians of the nineteenth century, “John Bright, Mr. [Richard] Cobden or Mr. [William] Gladstone himself, never at any time of their career proposed the adoption of manhood suffrage" for the very same

${ }^{62}$ LAC, Sir Wilfrid Laurier fonds, MG 26-G, "Political correspondence" series, volume 42, reel C748, page 18340, letter from Wm. Trant to Wilfrid Laurier, 10 April 1897. Aside from frequent correspondence with Prime Minister Laurier, William Trant led a very interesting life. Born in Leeds, England, he was a journalist by profession. He first worked for the Yorkshire Post, which he subsequently quit to become a journalist in London. Travelling to Paris, he acted as a special correspondent during the whole time of the Paris Commune and its suppression. After having his dispatches intercepted, Trant was arrested, imprisoned, and sentenced to death - a sentence he narrowly escaped. On press missions, he subsequently travelled to India (where he accompanied the Prince of Wales on his tour of the subcontinent), Spain, Algeria, Morocco, the United States, and Mexico. He moved his family to the Canadian Northwest in 1889. There, Trant seemingly did everything: he was a school trustee, a Justice of the Peace, a lawyer, a police magistrate, a novelist, a lecturer, and a president of the Canadian Club in Regina. Politically, he had acted as an organizer of England's Financial Reform Association and, in 1883, founded the so-called Radical Federation. See: Morgan, ed., 1107. 
reason. ${ }^{63}$ British politicians such as Prime Minister Gladstone had avoided the institution of manhood suffrage to protect the state against the supposedly uninformed decisions of the state's most imprudent, unthinking, or economically irresponsible members. In following this long line of liberal thought, Laurier broke no new ground when he himself evocatively explained that he also did not believe in manhood suffrage and, as a result, refused to introduce it federally within Canada. ${ }^{64}$

Despite their increasing inclusiveness, the provincial franchises seemed to suit these liberal beliefs. Undoubtedly, Quebec maintained the most restrictive franchise in Canada when the Liberals passed their franchise reform in 1898. Traditional Catholic anti-republican and anti-democratic views concerning the suffrage still held sway, despite Pope Leo XIII's continued attempts to reconcile the Church with modern liberal thought. Indeed, in 1891, the Pope issued what commentators have since called "his greatest encyclical" and "the Magna Charta of Social Catholicism", the Rerum Novarum. ${ }^{65}$ While

${ }^{63}$ Hansard, vol. XLVI, 21 April 1898, 4010. Prolific speakers and writers, partners in radical reform, and sitting members of Great Britain's Liberal party, Englishmen Richard Cobden (1804-1865) and John Bright (1811-1889) worked throughout the nineteenth century for the expansion of personal freedoms and individual rights in England. While such work most famously revolved around their advocacy of freer trade and their consequent stand against the Corn Laws - import tariffs on corn that raised corn prices in Great Britain - they also sought parliamentary reform as well. As part of this demand for parliamentary reform, both Cobden and Bright promoted an expansion of the franchise. On the one hand, Cobden favoured the establishment of the freehold franchise in the counties, whereby an adult male who owned real property of any value would receive a vote. Bright, on the other hand, was perhaps even more radical than Cobden when it came to the suffrage. He wished to see a taxpayer franchise in the boroughs and a $£ 10$ rental franchise in the counties (a franchise very similar to the one Benjamin Disraeli instituted in 1867). Despite their desires for an expanded suffrage, neither Cobden nor Bright apparently endorsed manhood suffrage. See: Miles Taylor, "Cobden, Richard", Oxford Dictionary of National Biography, vol. 12, eds. H.C.G. Matthew and Brian Harrison (New York and Oxford: Oxford University Press, 2004), 284-289; Miles Taylor, "Bright, John", Oxford Dictionary of National Biography, vol. 7, eds. H.C.G. Matthew and Brian Harrison (New York and Oxford: Oxford University Press, 2004), 628; 630; 632-633; 635. For more on Cobden's and Bright's partnership, especially in connection with parliamentary reform and franchise reform, see: Donald Read, Cobden and Bright: A Victorian Political Partnership (London: Edward Arnold, 1967), 149-177.

${ }^{64}$ Again, see: Hansard, vol. XLVI, 21 April 1898, 4010-4011.

${ }^{65}$ Holland, 176. Although Rerum novarum literally translates to "of new things", its English version has most often been titled On the Condition of the Working Class. See: Ibid. 
it denounced anything that smacked of socialism, the encyclical also refused to pass judgment on "the particular form of government prevailing in this or that nation" as long as it serves to "realize public well-being and private prosperity". ${ }^{66}$ Although the Pope never forthrightly supported the spread of liberalism in his encyclical of 1891 , he never explicitly denounced it either. It therefore seems that through the Rerum Novarum, the Church had allowed Quebecers to choose their own provincial political philosophy, as long as that choice did not lead to socialism. Despite this freedom, the vast majority of Quebecers - yet, in comparison with 1885 , a diminishing majority - had apparently chosen to maintain their generally conservative views of the franchise. ${ }^{67}$ Yet, Quebec was not alone in maintaining restrictive elements within its franchise legislation. Even those provinces that had supposedly instituted manhood suffrage - British Columbia, Manitoba, Ontario, and Prince Edward Island - still imposed disqualifications upon some

\footnotetext{
${ }^{66}$ Catholic Church, "The Condition of the Working Classes", The Great Encyclical Letters of Pope Leo XIII, 227-228.

${ }^{67}$ Expectedly, ultramontaine newspapers in Quebec denounced the liberal underpinnings of the Franchise Act of 1898. For example, the highly Catholic Courrier du Canada (published out of Quebec City) strongly believed that forcing the Liberals to accept Conservative amendments to the legislation would undoubtedly improve the project. See: "La loi de franchise", Courrier du Canada, 8 May 1898, 2. On the other hand, the year after the Liberals passed their Franchise Act of 1898, the Montreal-based Parti Ouvrier formed. Playing a "very active role on the Montreal political stage" for "about ten years at the beginning of the [twentieth] century", it pressed for the establishment of universal suffrage within Quebec. See: Paul-André Linteau, René Durocher, and Jean-Claude Robert, Quebec: $A$ History 1867-1929, trans. Robert Chodos (Toronto: James Lorimer, 1983), 495-496. During the franchise debates of 1897 and 1898 , the radical Montreal newspaper, La Presse, reflected this budding demand for the introduction of a more inclusive franchise within the province. In 1885, La Presse had originally viewed "avec crainte les tendances qu'il manifeste en faveur du suffrage universel". It consequently positioned itself against Prime Minister Macdonald's legislation, which was less restrictive than Quebec's franchise. One would therefore imagine La Presse would have supported Prime Minister Laurier's repeal of that legislation. Instead, it criticized the Liberals' electoral reform, remarking that "Elle a pour elle la suppression d'une dépense considérable : c'est son seul avantage." Because it feared provincial repression of the federal government and even further electoral corruption and fraud, however, it asked: "Pourquoi ne pas avoir au pouvoir le courage d'affirmer les doctrines qu'on a soutennes dans l'opposition et accepter purement et simplement le suffrage universel, avec le cens de la résidence". Changing its views considerably since 1885, La Presse had therefore advocated that any male person over the age of majority with a domicile in Quebec should receive a provincial ballot. Despite these words, Quebec would not bestow the provincial vote upon the majority of its male inhabitants (through substantially reduced income qualifications) until 1912. See: "Le Parlement", La Presse, 13 April 1885, 2; "Le Discours du Trône", La Presse, 26 March 1897, 4. See also: Elections Canada, 57.
} 
of their inhabitants. For example, British Columbia still disenfranchised all inhabitants of Asian and Aboriginal descent.

Moreover, such disqualifications from the franchise were not solely levelled against racial minorities. In a letter to Ontario Premier James Whitney, a (presumably white) resident and property-owner named C. H. Wood complained that when he went to cast his ballot in Cornwall, Ontario, he "found [himself] disfranchised on a temporary absence". ${ }^{68}$ In other words, the revising barrister had struck his name from the voters' list because he had been absent from the constituency for too long (thus following Ontario's franchise law). ${ }^{69}$ Because of such supposedly unfair franchise legislation where "property owners have not as much interest as some of the parties who even qualified to vote at last election" - Mr. Wood declared that he felt "like quiting [sic] Ontario for good" ${ }^{70}$ Although it is impossible to tell how many other Canadians found themselves in the same situation as Ontario's C. H. Wood, his disenfranchisement reflected the fact that even certain property-owners in those provinces that had reportedly instituted manhood suffrage found themselves without a federal ballot because of the Liberal Franchise Act of 1898. In ensuring that universal manhood suffrage would not

\footnotetext{
${ }^{68}$ Archives of Ontario, Sir James Pliny Whitney Papers, F 5-1, "Correspondence" series, MU 3113, Whitney (James P) Papers August 1897 - December 1899, C. H. Wood to Sir James P. Whitney, 19 July $1898,1$.

${ }^{69}$ According to section 7.2 of The Ontario Election Act, 1892, "A person may be resident in the municipality within the meaning of this Act, notwithstanding occasional or temporary absence in the prosecution of his occupation as a lumberman, mariner, or fisherman, or attendance as a student in an institution of learning in the Dominion of Canada; and such occasional or temporary absence shall not disentitle such person to be entered on the assessment roll or voter's list as a qualified voter, or to vote." Since the section never specifies the duration of an "occasional or temporary absence", it fell to the revising barrister to make such a judgement. It seems that in the case of Mr. Wood, the revising barrister ruled unfavourably. See: Ontario, Statutes of the Province of Ontario, 55 Victoria, 1892, 16. Furthermore, such a disqualification should not occur under Canada's current federal electoral system. As long as an individual is a Canadian citizen and has reached the age of majority, he or she may cast a ballot. Rules governing absentee voting ensure even those Canadians not presently residing in their home constituency may have their say come election day. See: Elections Canada, 78-79; 89-100.

${ }^{70}$ Archives of Ontario, C. H. Wood to Sir James P. Whitney, 1.
} 
gain a complete foothold in Canada at the federal level, the Liberals consequently followed classical liberal ideology concerning the franchise once again, aligning themselves with party forefathers such as George Brown, Alexander Mackenzie, and even Edward Blake. ${ }^{71}$ Undoubtedly, the Franchise Act of 1898 expanded the federal franchise considerably. That being said, it did not expand beyond the limitations set forth by contemporary liberal scholars. As a result, the Liberals' franchise act mirrored classical liberal ideology in every way. The republican notion that all male inhabitants of the state had a right to vote would therefore have to wait in the Canadian context. But, as Prime Minister Laurier made so abundantly clear, the Liberals did not wish to fashion a republican state in the first place.

If the Electoral Franchise Act of 1885 represented John A. Macdonald's attempt at conservative state formation, it appears that the Franchise Act of 1898 may have similarly represented Wilfrid Laurier's attempt at liberal state formation. By replacing the Conservatives' franchise reform with one of their own design, the Liberals apparently hoped to offset the formative potential of their opponents' franchise law. In endeavouring to counteract existing suffrage legislation, however, Prime Minister Laurier had his own precedent. One of Laurier's own political idols, former Liberal British

\footnotetext{
${ }^{71}$ Recall that throughout his political career - including the debates concerning Confederation George Brown resisted republican institutions such as universal manhood suffrage with all the strength he could muster. Brown's successor, Alexander Mackenzie, took a similarly negative stance toward republican ideas of electoral law. Even though he introduced the secret ballot federally in 1874 during his sole term as prime minister, he himself tended to agree that anyone who wished to cast a ballot should have the courage to stand in front of his peers and openly announce his choice of candidate. Even Prime Minister Laurier's predecessor, Edward Blake, believed that Canada should not institute universal manhood suffrage. Unlike Laurier, Blake did not see the necessity for property qualifications placed upon the franchise. He instead desired (like John Stuart Mill) to see "that intelligence established by an easy test... with reference to reading and writing" be used determine whether an individual should receive a ballot. In true liberal fashion, such a test would of course restrict the number of people who could access the suffrage. For Mackenzie's view, see: Dale C. Thomson, Alexander Mackenzie: Clear Grit (Toronto: Macmillan, 1960), 194. For Blake's view, see: Hansard, vol. XVIII, 17 April, 1885, 1187. For Mill's view, see again: Mill, On Representative Government, 170; 180.
} 
Prime Minister William Gladstone, ${ }^{72}$ had undertaken a similar project fourteen years earlier with the Representation of the People Act of 1884, otherwise known as the Third Reform Act. ${ }^{73}$ When Gladstone tabled the Third Reform Act, Britons' views regarding the franchise were much different than those they expressed in 1867, when Conservative Prime Minister Benjamin Disraeli instituted the Second Reform Act. Recall that throughout 1866 and 1867, public pressure for more inclusive franchise legislation threatened to erupt into violence. Disraeli's government had to act. They did so by implementing a surprisingly radical piece of suffrage legislation. Although a $£ 10$ property qualification still existed within England's rural county constituencies, the Second Reform Act had virtually established manhood suffrage within the nation's urban borough ridings. With England's urban labourers finally able to cast a vote, most Britons saw no need to agitate for further franchise extensions. Consequently, public pressure for a wider suffrage subsided. Nevertheless, in the penultimate year of his second ministry, Gladstone went ahead with his own franchise reform and extended the same household

\footnotetext{
${ }^{72}$ During his elegy spoken upon the occasion of Gladstone's death, Laurier delivered the following words in honour of his "ami": "La dernière moitié du siècle dans laquelle nous vivons a produit bien des hommes sages et forts qui, dans les différentes circonstances de la vie, ont captivé l'attention de tous ; mais de tous les hommes qui ont illustré leur époque, il me semble qu'aux yeux de la postérité il s'en détache quatre qui dépassent et effacent tous les autres, ce sont : Cavour, Lincoln, Bismarck et Gladstone...M. Gladstone a certainement surpassé tous ceux-là ; il concentrait en lui une variété de forces humaines qu'il est rare de rencontrer dans un seul homme. Il avait le gout, l'imagination, la conception poétique des choses qui manquait au comte de Cavour. Il possédait l'aptitude aux affaires et l'habilité financière que n'a jamais montrées Lincoln. Il possédait les nobles sentiments, l'inspiration généreuse que le prince Bismarck a toujours négligés quand il ne les méprisait pas." From this speech, one can see that Laurier viewed Gladstone as the greatest politician of his time. See: Laurier, 122-124.

${ }^{73}$ Although most people associate the Gladstone's Reform Act with franchise reform, the Third Reform Act, as Mary E. J. Chadwick explains, "was in fact a package of ten bills either introduced or accepted by the government." These other bills included Registration Bills for England, Scotland, and Ireland (that would introduce a shared voter registration procedure across the Three Kingdoms), an Hours of Poll Bill (that universalized polling hours), and a Redistribution Bill (that would refashion Great Britain's political constituencies). Further analysis of the Redistribution Bill in particular will occur later in this chapter. See: Mary E. J. Chadwick, "The Role of Redistribution in the Making of the Third Reform Act", The Historical Journal 19.3 (September 1976), 666.
} 
suffrage legislation enjoyed by the boroughs to the nation's county ridings as well. ${ }^{74}$ In doing so, he ended up adding between 1.6 million and 1.8 million names to the nation's voters' lists. ${ }^{75}$ By adopting liberal political philosophy in this way, Gladstone thus raised the proportion of eligible voters from twenty-eight percent to fifty-eight percent of Britain's male population. $^{76}$

Within the historiography covering franchise reform in Great Britain, Gladstone's franchise act of 1884 has received nowhere near the same attention as its two climatic predecessors of 1832 and 1867. As University College (London) historian Mary E. J. Chadwick has hypothesized, other parliamentary business, namely the Irish Home Rule question, may have helped to overshadow it. ${ }^{77}$ That being said, scholars on the subject have forwarded certain explanations as to why Gladstone's Liberal government reformed the British franchise despite the absence of public agitation for such a reform. In perhaps

${ }^{74}$ Ibid. See also: Hugh W. Stephens, "The Changing Context of British Politics in the 1880s: Reform Acts and the Formation of the Liberal Unionist Party", Social Science History 1.4 (Summer 1977), 487.

${ }^{75}$ In his monograph on British politics in the age of Disraeli and Gladstone, the aforementioned Kingston University historian Paul Adelman has estimated that Gladstone's Representation of the People Act provided the franchise to 1.6 million previously disenfranchised Britons. Journalist Paul Foot, on the other hand, provides a much more specific number. According to his text on the vote in Great Britain, Gladstone's legislation created 1,762,441 new voters. Unfortunately, neither Adelman nor Foot provide the source of their statistics. See: Adelman, 85; Paul Foot, The Vote: How It was Won and How It was Undermined (London: Viking, 2005), 167.

${ }^{77}$ Stephens in Social Science History, 487.

${ }^{77}$ Chadwick in The Historical Journal, 665. Irish Home Rule refers to the nineteenth-century movement for Irish legislative independence from Great Britain. Throughout the 1880-1885 Parliamentary session, Prime Minister Gladstone struggled with unrest in Ireland. To many, granting Home Rule to Ireland seemed to represent the only solution to the problem. As pressure outside the British Parliament grew in support of Home Rule, the results of the December, 1885 election created a new source of pressure within Parliament. Although Gladstone's Liberals won the election with 333 seats, the Irish party - a party dedicated to Irish Home Rule - held the balance of power in the new Parliament with 86 seats. In partial response to this parliamentary situation, Gladstone introduced his Home Rule Bill in April of 1886. As Cambridge historian Eugenio F. Biagini explains, however, "Gladstone had not prepared the [Liberal] party for such a dramatic development of his Irish policy and the shock was considerable." Although a majority of Liberals ended up siding with Gladstone, the Home Rule question ended up dividing the Liberal party. As a result, Gladstone's government was defeated by 341 votes to 311 in April of 1885 . He would not return to power until 1892. See: Eugenio F. Biagini, British Democracy and Irish Nationalism 1876-1906 (Cambridge: Cambridge University Press, 2007), 7-10. See also: Alvin Jackson, Home Rule: An Irish History, 1800-2000 (New York and Oxford: Oxford University Press, 2003), 56-64. 
the most detailed study of the political minutia that led to franchise reform in 1884 , University of Reading historian Andrew Jones advances the argument that Gladstone's Third Reform Act represented both the logical extension of party policy on the franchise and the logical extension of Disraeli's Second Reform Act. From the early 1870s onward, Liberal Member of Parliament George Otto Trevelyan almost annually tabled legislation that would extend the household franchise to the rural counties. ${ }^{78}$ Viewing it as a fair way to standardize access to the suffrage, thereby affirming the classical liberal tenet of equality of opportunity, more and more Liberals joined Trevelyan's cause as the decade progressed. By the time that the electoral campaign of 1880 had ended, Jones cites that a total of " 153 of the returned Liberals, including the candidate for Midlothian [William Gladstone himself], had made favourable and specific mention of the measure in their election addresses..."79 It was therefore no surprise when Gladstone finally tabled his franchise bill within the House of Commons in October of 1883 - especially when one considers the fact that the National Liberal Federation, during its meeting of the same month, voted that new franchise legislation should take "precedence over any Local or Metropolitan Government bills" ${ }^{80}$ Although it took over a year to become law (because of an obstinate House of Lords), the British franchise finally attained parity amongst urban and rural ridings on December $1,1884{ }^{81}$

\footnotetext{
${ }^{78}$ Andrew Jones, The Politics of Reform 1884 (Cambridge: Cambridge University Press, 1972), 3.

${ }^{79} \mathrm{Ibid}$.

${ }^{80} \mathrm{Ibid}$. According to Liberal Member of Parliament and future Colonial Secretary Joseph Chamberlain, "Mr. Gladstone considered that this subject [franchise reform], entailing as it would a new dissolution, ought to be deferred till towards the close of the Parliament just elected." See: Joseph Chamberlain, A Political Memoir, 1880-1892, ed. C. H. D. Howard (London: Batchworth Press, 1953), 4. Incidentally, Joseph Chamberlain was father to future British Prime Minister Neville Chamberlain.

${ }^{81}$ Jones, 8.
} 
Of course, as mentioned earlier, parity within the franchise resulted in the enfranchisement of 1.6 to 1.8 million Britons. Bearing in mind that the Representation of the People Act expanded the franchise in Britain's rural regions, the majority of these newly enfranchised voters - nearly two-thirds of them - were agricultural labourers who did not own farms of their own. ${ }^{82}$ As such, these new voters tended to be poorer financially, much like their labouring brethren in the cities. If poorer, unpropertied urban labourers tended to support the Liberal cause, Gladstone's Liberals may have presumed that poorer, unpropertied rural labourers would do the same. ${ }^{83}$ Indeed, as Mary Chadwick has contended, "[l]eading Conservatives" similarly feared that franchise reform would result in the "return [of] a Radical Government from the constituencies swamped by the newly enfranchised voters.

According to the statistics provided by University of Houston political scientist Hugh W. Stephens, the Conservatives were right to fear the transformative potential of Gladstone's franchise reform. Before 1884, the Liberals tended to win seats in constituencies with below-national average numbers of registered voters. After the passage of Gladstone's Reform Act, however, the Liberals began to take more constituencies boasting above-national average numbers of registered voters. ${ }^{85}$ With more Britons on average voting Liberal after Gladstone introduced his Representation of the People Act, Stephens concludes that "the Liberals did benefit from lowering the voter

${ }^{82}$ Stephens in Social Science History, 487; Foot, 167. Paul Foot cites that despite the rapid industrialization of Great Britain, agriculture still represented the largest employer of labour in 1884. See: Foot, 167.

${ }^{83}$ For the political tendencies of Great Britain's urban lower classes, see the previous chapter of this document.

${ }^{84}$ Chadwick in The Historical Journal, 667.

${ }^{85}$ Stephens in Social Science History, 494 (see Table 4). 
qualifications in the counties". ${ }^{86}$ As the number of prospective Liberal voters rose

because of their franchise reform, the Liberals could have consequently expected a better

chance of returning to power and a greater opportunity to inscribe further liberal

measures within the nation's statute books. Prime Minister Disraeli's attempt at state

formation through franchise reform was therefore turned on its head by Prime Minister

Gladstone: by enfranchising even more Britons, the British Liberals had seemingly turned

political disadvantage into political advantage. ${ }^{87}$

When Prime Minister Laurier entered into his first ministry in 1896, he had faced

the same sort of politically unfavourable situation as Gladstone had faced before he had

entered office in 1880. Prime Minister Macdonald, apparently following the precedent

\footnotetext{
${ }^{86}$ Ibid., 493.

${ }^{87}$ Unlike Disraeli's Second Reform Act of 1867, however, Gladstone's franchise reform in 1884 did not itself contain a redistribution of legislative seats. Such a redistribution - in the form of the Redistribution Act of 1885 - would not arrive until the following year. As soon as Gladstone announced an expansion of the franchise, the opposition Conservatives feared that the swarm of new voters would give a decided electoral advantage to the Liberals. Fortunately for the Conservatives, they still dominated the House of Lords. Arguing that Gladstone's franchise bill contained no redistribution of seats - which the Conservative Peers viewed as both necessary and as a way to hedge the Liberal advantage - the House of Lords, on July 8, 1884, rejected the legislation. Still desiring franchise reform, Gladstone reintroduced his legislation to the Commons after Parliament reconvened after the summer recess. After passing the House committee stage, the Lords received the bill once again on November 18. This time, however, both Gladstone and Granville George Leveson Gower, the $2^{\text {nd }}$ Earl of Granville (Liberal leader in the upper house) promised that they would allow redistribution if the Lords passed the Liberals' franchise reform. With the Conservatives getting what they desired, the Representation of the People Act became law in December, 1884. When the promised Redistribution Act came into effect the following year, Great Britain's constituencies underwent a massive reorganization. This was especially true with respect to its urban borough ridings. Before, British cities for the most part received only a couple of seats to represent their large and primarily Liberal populations. With such a mass of Liberal support behind them, borough ridings would generally return Liberal Members of Parliament. Through the redistribution of 1885 , neighbourhood boundaries would now serve to demarcate different city constituencies. Since some neighbourhoods were more affluent than others, Paul Adelman argues that urban constituencies were therefore "carved up deliberately on largely 'class' lines". Such divisions conferred a considerable advantage to the Conservatives. As James Cornford explains, "Where Conservative supporters had formerly been swamped in huge constituencies, they were now high and dry on islands of their own." Because of this redistribution of seats, the Conservatives for the first time won a majority in the English boroughs in the 1885 general election. They would continue to do well in the boroughs during the next four elections as well, leading them to three majority governments. "When passed through the net of redistricting", Hugh W. Stephens rightly contends that the Liberals, as a consequence of the Conservatives' obstinacy, "could not transform the advantage of the Franchise Act into [multiple majorities] in the Commons." See: Jones, 6-8; Adelman, 86; James Cornford, "The Transformation of Conservatism in the Nineteenth Century", Victorian Studies 7.1 (September 1963), 58; Stephens in Social Science History, 494.
} 
set by Prime Minister Disraeli, had set Canada's franchise legislation to clearly favour himself, his party, and conservatism in general. Indeed, Macdonald's machinations with respect to the suffrage seemed to have worked so well that, despite remarkably weak party organization in 1896 , the Conservatives still took more votes than the victorious Liberals. ${ }^{88}$ To extricate himself and his party from this political sinkhole, Laurier did what Gladstone had done fourteen years earlier: replace the state's existing franchise legislation with something that lent itself much more easily to both liberal political philosophy and Liberal political success. Where Gladstone added to and expanded Great Britain's existing franchise law to accomplish this goal, Laurier simply repealed the offending legislation altogether. In doing so, Laurier achieved a similarly substantial expansion of the nation's franchise.

By expanding Canada's franchise in this way, the Dominion government permitted a substantial number of poorer Canadians to cast a ballot federally. With immigration to Canada mounting quickly - thanks to the efforts of Prime Minister Laurier's Minister of the Interior, Clifford Sifton - these numbers would come to include a substantial number of recent immigrants as well. ${ }^{89}$ If poorer Canadians tended to vote Liberal, individuals who immigrated to Canada during the Laurier years had an even

${ }^{88}$ Recall that the Conservatives garnered 414,838 votes in 1896 while the Liberals managed only 405,185 (a difference of 9,653 votes). Again, see: Beck, Pendulum of Power, 86.

${ }^{89}$ Born in Upper Canada on March 10, 1861, Clifford Sifton moved with his family to Manitoba in 1875. A lawyer by training, Sifton entered the Manitoba legislature (after several failed attempts) as a Liberal in 1888, sitting for the constituency of North Brandon. After a stellar showing within Premier Thomas Greenway's Liberal government, Sifton joined Wilfrid Laurier's federal Liberal government in 1896 as Minister of the Interior. A born organizer and tireless worker, Sifton immediately set about transforming the immigration branch of the Department of the Interior with one goal in mind: to put in place the machinery necessary for the agricultural settlement of the Canadian west. By means of his promotional campaigns, Sifton's department managed to attract hundreds of thousands of immigrants from the United States, England, France, northern Italy, and eastern Europe to Canada. See: David J. Hall, "Sifton, Sir Clifford", Dictionary of Canadian Biography, vol. XV, 941-944. See also: Valerie Knowles, Strangers at Our Gates: Canadian Immigration and Immigration Policy, 1540-1990 (Toronto and Oxford: Dundurn Press, 1992), 58-59; 61-62. 
greater propensity to support the Liberal cause. Constant emphasis on the Liberals' role in opening Canada to immigration helped ingrain a sense of gratitude and loyalty into many of these new Canadians. ${ }^{90}$ Without the Liberals' decision to open the franchise, the vast majority of poorer Canadian men, many of them immigrants, would have never had the opportunity to cast a ballot once they finally found a place to settle. ${ }^{91}$ In creating so many new Liberal voters, the Liberals would have had a much greater opportunity of winning future federal elections. Considering that Prime Minister Laurier ended up leading the Liberals to consecutive electoral victories in 1900,1904 , and 1908, his alteration of the nation's franchise law may have in part helped him achieve his party's resounding electoral success. ${ }^{92}$ As in 1885 , however, such a recomposition of the electorate had the potential to spark further changes as well. With political citizenship

${ }^{90}$ Throughout the immigration boom during the Laurier years, the Liberals continually coupled their immigration efforts with attempts to reach out to newly arrived Canadians. In his article on the immigrant vote in early twentieth-century Saskatchewan, University of Regina historian J. William Brennan explains that the Liberals thought it "important to establish contact with newcomers as soon as they arrived" because "it is at this time that they are most easily moulded one way or the other". In this way, many immigrants reportedly came to equate "prosperity and success with Liberalism". Soon, as Brennan argues, the Liberals had come to "[count] on the support of voters only recently arrived from Europe or the United States". While many Liberal-voting immigrants to Saskatchewan would have most likely received a parcel of land upon their arrival, one could assume that a majority of those immigrants who had to rent their dwellings would have also voted Liberal. See: J. William Brennan, "Wooing the 'Foreign Vote': Saskatchewan Politics and the Immigrant, 1905-1919", Prairie Forum 3.1 (1978), 66-67. Anecdotally, one of my own great-grandfathers immigrated to British Columbia from then Czechoslovakia as a manual labourer in 1909. Not owning real property himself when he arrived, he most likely would have been disenfranchised by the Conservatives' Electoral Franchise Act of 1885 had it still been in effect. From what I gather, he was an avowed Liberal throughout his life. Similarly, another of my greatgrandfathers immigrated to Ottawa from Austria in 1913. Relatively poor himself when he arrived, he was also a staunch Liberal when it came to politics.

${ }^{91}$ Although the Laurier government wooed immigrants to Canada with promises of free agricultural land, "many new arrivals", as journalist Valerie Knowles explains, "particularly those from eastern and central Europe, found work in industry because settling on the land in Canada was then, as now, an expensive business and few immigrants had the necessary capital to take up farming right away. Temporary employment in railway construction, mining or lumbering was absolutely essential for most prospective farmers." Consequently, a large number of new immigrants during the Laurier years would not have owned real property of their own. Even so, the majority of these new Canadians who worked lowpaying jobs and who did not own real estate would have received a federal ballot as a result of the Franchise Act of 1898. See: Knowles, 73-74.

${ }^{92}$ For discussions of these federal elections, see: Beck, Pendulum of Power, 87-119. 
extended to more Canadian liberals (and Liberals) than ever before, one could reasonably expect a corresponding shift within the nation's political culture. Because of the Liberals' Franchise Act, liberal-minded (and Liberal-minded) Canadians had the potential for a much stronger voice within the federal sphere. Alongside this political clout came the enhanced ability to demand further liberal changes to the country's statutes. The Conciliation Act of 1900 perhaps represents a good instance of this. ${ }^{93}$ With liberalization of the Canadian state more readily received by the body politic, the state would have had a newfound capacity to undergo another ideological reorientation: if the Electoral Franchise Act of 1885 promoted conservative state formation, the Franchise Act of 1898 hoped to reverse any gains made by those previous efforts. The new century, therefore, looked particularly bright for Canadian liberals. Not only did Prime Minister Laurier's franchise reform appear to participate in a project that would usher out conservatism at the federal level; it also left the door wide open for the state to fill that void with further liberal policy.

With the implementation of the Liberal party's Franchise Act on June 13, 1898, the Dominion franchise had apparently come full circle. The provincial legislatures had controlled federal franchise legislation in the period following Confederation. Now, thirty-one years later, after a hiatus of Conservative-engineered central control, the provinces had gained control over the same legislation once again. In repealing the Electoral Franchise Act of 1885, the old had become new once more. Still, a return to a

${ }^{93}$ Through the Conciliation Act of 1900 , employers and employees could call upon the federal government to appoint conciliation officers to resolve labour disputes. Although the concilators' report was non-binding, the hope was that process would bring public attention to the dispute to force a reasonable settlement. In true classical liberal fashion, the Conciliation Act, therefore, attempted (through government intervention) to protect the individual rights of both employers and employees for the benefit of all. See: Robert Craig Brown and Ramsay Cook, Canada 1896-1921: A Nation Transformed (Toronto: McClelland and Stewart, 1974), 121. 
provincially-governed Dominion franchise did not mean a reversion to the same set of highly restrictive franchises enforced at the time of Confederation. Between 1867 and 1898, every Canadian province - with the notable exception of Quebec - had seen fit to frame rather inclusive pieces of franchise legislation, many verging upon universal manhood suffrage. Although the Franchise Act of 1898 certainly did not confer the federal vote upon all male inhabitants of Canada, or any of its female inhabitants for that matter, it extended the suffrage well beyond the limits imposed by John A. Macdonald's Conservative government in 1885 . Even though the provinces had regained control over the Dominion franchise, such control ensured Canadians a degree of access to the federal vote never before witnessed in the nation's history.

Much like Prime Minister Macdonald before him, Prime Minister Wilfrid Laurier and his Liberal party had several overlapping reasons for undertaking franchise reform. On the surface, the Liberals billed their repeal of the Electoral Franchise Act of 1885 simply as good governance. That legislation had reportedly cost Canadians too much money to enforce, and Canadians from all walks of life supposedly viewed it as wasteful. Repeal, on the other hand, represented a cost effective alternative. In repealing the Conservatives' act, however, the federal Liberals could have also expected additional, more partisan benefits. With Liberal governments leading six of the seven provinces, provincial governance of the Dominion franchise had the potential to work very much in Prime Minister Laurier's favour. Considering that the federal Liberals touted themselves as the party of provincial rights, Laurier could have hoped that Liberal provincial governments would help their federal cousins come election time with advantageous legislation, favourable voters' lists, or the use of provincial election machinery. And 
even if the provincial Liberals did not go so far, the prime minister could have at least expected his provincial counterparts not to work against him. Aside from good governance and political partisanship, however, one other reason for the passage of the Franchise Act of 1898 emerges: that of party ideology.

Perhaps the most important factor behind the Liberals' franchise legislation, party ideology contributed not only to who would govern the resultant franchise, but also its remarkably expansive scope. If the federal Liberal party portrayed itself as the party of provincial rights, it also billed itself as the party of small central government. Taking their cue from classical liberal philosophy, as derived largely from the seventeenthcentury writings of John Locke, Canada's Liberals had maintained since their inception that a small central government (and stronger local governments) could better satisfy the desires of the political community. By replacing Canada's uniform federal franchise with those of the provinces, the Liberals argued that they better accounted for the wide range of opinions concerning the franchise found across Canada. These provincial franchises were, however, much more inclusive than the legislation they replaced. Conveniently for the Liberals, such an expansive franchise also fell in line with classical liberal thought. From Montesquieu to John Stuart Mill, classical liberals had advocated a franchise that all citizens could potentially access. Although they believed that the state should place certain restrictions upon the franchise - especially with regard to the uneducated and the destitute - these liberals preached that most everyone should receive a vote. In broadening the federal franchise, but not to the point of universal manhood suffrage, the federal Liberals seem to have, once again, followed the ideas of classical liberalism to the letter. 
By respecting classical liberal ideology in this way, however, another possibility opened for Prime Minister Laurier's Liberal party regarding the overall effect of new franchise legislation. In 1884, Liberal British Prime Minister William Gladstone instituted a little-demanded franchise reform in part to further engrain liberal values within the very fabric of the British state. With this precedent in place, it appears that Canada's Liberals may have done much the same thing with their Franchise Act of 1898. Through their repeal of the Electoral Franchise Act of 1885, the Liberals enfranchised a large majority of the less wealthy yet liberal-minded Canadians disenfranchised by the repealed legislation. As a consequence, many more Liberal voters - including those individuals newly immigrated to Canada - came to comprise the nation's body politic. In doing so, the Liberals apparently hoped to turn political disadvantage into political advantage by giving themselves a greater opportunity for re-election. That being said, it appears that the Liberals franchise reform also represented the Liberals' own attempt at the larger project of state formation. By enfranchising so many probable Liberal voters, Canada's political culture would expectedly shift even further toward liberalism. With a strong liberal political culture in position, the potential for the nation's body politic to accept further liberal legislation would undoubtedly increase. If this potential could manifest itself, the Liberals' franchise reform could consequently erase any conservative gains made by the preceding franchise legislation and propel the Canadian state down the liberal path. With the Liberals' convincing electoral win in 1900 under the auspices of their franchise act, it seems that, at the end of the nineteenth-century, this project of liberal state formation was well underway. 


\section{Conclusion}

On May 16, 1885, the fiercely independent Montreal Daily Star published yet another editorial on the changing state of the Dominion's electoral franchise. Entitled "The Grits and the Franchise Bill", it marked the one month anniversary of Parliamentary debate concerning the Conservative party's Electoral Franchise Act. Like most other nineteenth-century Canadian newspapers, the Star - a pioneer of mass-circulation newspapers - had already devoted considerable space within its pages to discuss the nature of the suffrage in Canada. During the preceding month, Star editor Hugh Graham had already penned four other opinionated articles on the same general subject. ${ }^{1}$ Moreover, his editorial of May 16 would by no means be his last. As the federal franchise underwent further, seemingly incongruous alterations toward the end of the century, the Star, alongside newspapers from across the country, was quick to offer both praise and criticism. Of this collection, however, the "The Grits and the Franchise Bill" stands out in particular. While the body of the editorial principally discusses the offensive nature of the revising barrister clause embedded within the Electoral Franchise Act, Graham's opening sentence, perhaps better than anyone since, distils the rationale behind nineteenth-century Canadian federal franchise reform. As he so perceptively wrote 124 years ago: "The Franchise Bill is a statesmanlike measure with a partisan tail." ${ }^{2}$

\footnotetext{
${ }^{1}$ After cutting his teeth at the Montreal Daily Telegraph, Graham became a partner at the Montreal Daily Star in 1869. A British loyalist and a technological innovator in the newspaper business, he helped transform the Star into "Canada's largest and most profitable daily" by 1891 . For his work in support of the First World War effort, Graham was elevated to the peerage in 1917. He died in 1938. See: Douglas Fetherling, "Graham, Hugh, Baron Atholstan", Canadian Encyclopedia, vol. II, 920. For circulation statistics regarding Canada's leading nineteenth-century newspapers, see: Rutherford, 49.

2 "The Grits and the Franchise Bill", Montreal Daily Star, 16 May 1885, 2.
} 
Although Hugh Graham had penned this pithy sentence to specifically describe the Electoral Franchise Act of 1885 , his words quite readily apply to all federal franchise legislation that found its way into nineteenth-century Dominion statute books. Graham's analogy contains one particularly salient variable with respect to the three franchise reforms discussed within this paper: the size of the "partisan tail". When the Confederation delegates agreed upon Canada's inaugural franchise law, as drafted by John A. Macdonald and ensconced within section 41 of the British North America Act, the partisan tail attached to it was quite small. More interested in fashioning a franchise that all could easily agree upon - thereby diminishing the "[i]nsuperable difficulties" that, in Macdonald's opinion, would have derailed the talks concerning federal union - the delegates simply chose to employ the existing provincial franchises as the new federal franchise. In other words, those Canadians who could legally vote in provincial elections would receive a ballot in future federal elections as well. Fortunately for the Confederation delegates, this pragmatism nicely complemented their overall ideological outlooks.

In adopting provincial franchise legislation for the new Dominion franchise, the delegates to the Confederation negotiations ensured that strict property and income qualifications would regulate just who would receive a federal ballot. Although nineteenth-century election statistics remain largely inchoate, no more than twelve percent of all Canadians would have found their names on federal voters' lists when the Dominion's first general election commenced in August of 1867. Such restrictive franchise legislation endeared itself to the adherents of nineteenth-century Canada's two dominant political ideologies: conservatism and classical liberalism. For conservatives, 
inspired by the writings of Edmund Burke, the government should make the franchise as precious as possible by conferring the franchise solely upon those citizens who had demonstrated their independence through a substantial ownership of property. In doing so, the nation would continue to follow the same tradition that had supposedly served Great Britain so well in the past. Classical liberals, on the other hand, did not see the franchise as something that the government should necessarily deny the masses. Inspired by the ideas of thinkers such as Montesquieu and John Stuart Mill, liberals viewed the franchise as a measured privilege that all could potentially attain. In other words, they believed it should be an instrument of gradual but broad political empowerment. Even so, these liberals felt that one must still maintain certain restrictions - based upon property, income, education, or otherwise - upon the franchise to prevent undesirable inhabitants from negatively affecting the stability of the state. Consequently, the strong limitations placed upon the new nation's franchise suited the ideological predilections of leading Canadian conservatives such as John A. Macdonald, George-Étienne Cartier, Thomas D'Arcy McGee, and Charles Tupper, and leading Canadian liberals such as George Brown and Joseph Howe.

With section 41 of the British North America Act symbiotically satisfying conservatives and liberals alike, the Confederation delegates really only disregarded the philosophies of those Canadians whose political beliefs lay at the fringes of the political spectrum. Republicans for the most part, these Radical Canadians, such as Parti Rouge leader Antoine-Aimé Dorion, had for years endorsed the establishment of universal manhood suffrage within Canada. The excesses of "unbridled democracy" to the south, however, culminating in the American republic's hugely divisive Civil War, had served 
to ossify the stance of most Canadians against manhood suffrage, including those present at the Quebec Conference. Indeed, in the Province of Canada, George Brown's Reformers and John A. Macdonald's Conservatives had allied their parties in 1864 in part to guard against this republican threat, thus moderating or marginalizing more radical members of the legislature. By sweeping aside republican arguments concerning the franchise, the Reformers and Conservatives not only helped secure their sway over the Canadian legislature: they also set the groundwork for upcoming franchise legislation. Because of the ideological malleability of the Confederation franchise, future Canadian statesmen could draw Dominion franchise law in either a more conservative or a more liberal direction.

As Canada grew larger and stronger in the years following Confederation, the partisan tail on its franchise reforms grew longer as well. In 1885, now Prime Minster John A. Macdonald set forth to "complet[e] the Federal Constitution" (as he related to Lord Carnarvon) and finally give the federal Parliament a franchise of its very own. Arguing that it was not "worthy of our Parliament" to maintain legislation that allowed provinces, on a whim, to "tinker" with the federal vote, he touted his Electoral Franchise Act as a measure based upon the principle of good governance. Upon reading the proposed legislation, however, the opposition Liberals came to find much more partisan motivations behind Macdonald's bill. These partisan designs revealed themselves within section 14 of the act. Otherwise known as the revising barrister clause, the section allowed the prime minister himself to appoint those judges he desired to revise the nation's voters' lists. Besides providing another basket of plum patronage positions to dole out, it allowed the Conservatives to ensure that loyal party members would come to 
determine just who would receive a federal ballot. Sardonically asking "[w]hy not have the revising barrister do the voting directly, and not indirectly?", the Liberals decried the revising barrister clause as a clear Conservative attempt "to grasp the ballot box".

Despite its blatantly partisan nature, however, the revising barrister clause only represented one facet of a much larger legislative project.

While section 14 of the Electoral Franchise Act concerned itself with who would create the Dominion's voters' lists, the rest of the legislation outlined the rules the revising barristers had to follow when they fashioned those lists. Here lay the ideological current in which Prime Minister Macdonald wished to swim. Since Confederation, most provinces had reduced their franchise qualifications. Upon their entrance into the union, British Columbia and Prince Edward Island had even seen fit to introduce near-manhood suffrage. At the federal level, Macdonald's Electoral Franchise Act reversed this trend. When compared with those franchises maintained by the provinces (with the exception of Quebec), the property and income qualifications within the new Dominion franchise were thirty-three to two hundred percent more restrictive. In limiting access to the federal franchise in this way, the Prime Minister adhered to the same conservative ideology that framed his approach to the franchise at Confederation. As Edmund Burke himself suggested, alterations to the franchise should only take the form of restrictions. By introducing such a conservative franchise, however, the Conservative party apparently attempted to do more than simply reduce the number of Canadians who could vote federally. He sought to employ the franchise to shape the nation to fit his life-long ideological outlook. 
Taking his cue from British Prime Minister Benjamin Disraeli and his Second Reform Act, Prime Minister Macdonald, as one can plausibly conclude, endeavoured to insert his franchise reform into the larger project of state formation. Because property owners, on the whole, tended to uphold more conservative values, legislation that enfranchised property owners principally offered the opportunity of greater Conservative party success at the polls. Yet, a primarily conservative electorate had the potential to do more than simply return the Conservatives to office. As more conservatives came to compose the overall body politic, one would expect a corresponding conservative shift in Canada's political culture as well. Demands for further conservative legislation would rise. If all went as suggested, a slow shift right on the political spectrum would follow, heralding the formation of a more conservative Canadian state. The Electoral Franchise Act of 1885 therefore represented a highly-principled alteration of Canada's federal franchise law that stemmed from the paternalistic world of conservative political philosophy. Only its tail - the revising barrister clause - kept it tethered to the seedy sphere of nineteenth-century partisan politics.

Despite their repeated attacks on the Electoral Franchise Act, the Liberals applied a similar recipe of high-minded political philosophy and partisan tactical advantage when fashioning their Franchise Act of 1898. Citing the allegation that the Conservatives' franchise had both drained the federal coffers and failed to live up to the expectations of Liberals and Conservatives alike, the Liberals had similarly billed their repeal of the Electoral Franchise Act (and consequent return of the federal franchise to provincial jurisdiction) as a necessary reform for the good of the nation. Even so, the Conservatives quickly realized that this seemingly altruistic measure came with its own partisan tail 
attached. With Liberals dominating six of the seven provincial legislatures, the Franchise Act of 1898 left the door open to the sorts of electoral chicanery so loudly denounced by the Liberal party in the preceding years: from provincial juggling of the franchise law to favour the federal Liberals, to provincially-appointed Liberal revising barristers fashioning voters' lists that contained the names of proportionally more Liberal voters, to the use of provincial election machinery to the federal party's advantage. Because of the possibility of such partisan behaviour, George Eulas Foster, a Conservative partisan himself, concluded that "if it [the Liberals' bill] became law, we would be landed in exactly the same predicament [as with the Electoral Franchise Act of 1885]." Although a return to a provincially-governed federal franchise contained a partisan element to it, it did something more for the Liberals: it played into the larger ideological project they designed for their franchise reform.

In the years after Confederation, Canada's Liberal party had forcefully advocated for increased provincial rights and powers. Following classical liberal thinkers such as John Stuart Mill, the Liberals viewed local legislatures as better representatives of citizens' desires than a single, lumbering, autocratic central government. Liberal stalwarts such as Edward Blake and Oliver Mowat espoused pluralism as the surest preserver of liberty in a federal union. The Liberals' decision to return governance of the federal franchise to the provinces played directly to this philosophical outlook. So too did the overall inclusiveness of the new franchise. Between 1885 and 1898 , most provinces had undertaken another series of franchise expansions. Four of the seven provinces (with Nova Scotia, New Brunswick, and Quebec as the exceptions) had even seen fit to implement near-universal manhood suffrage. By 1898 , the provincial 
franchises, as a whole, gave many more Canadians the vote than the Electoral Franchise Act they replaced. In creating so many additional Dominion voters, the federal Liberals undoubtedly conformed to the classical liberal belief that governments should open the franchise wide enough so that all individuals have the opportunity of attaining it. Such was the essence of mid-Victorian liberalism. That being said, the Liberals by no means endorsed the headlong implementation of universal manhood suffrage across the whole of Canada. Once again echoing the liberal sentiments of Mill, Prime Minister Wilfrid Laurier argued that governments that choose to implement manhood suffrage would have also "prostituted their franchise." Because he ideologically "believe[d] that manhood suffrage is not the correct thing", he refused to impose that "tyranny" upon Canada. Thus, as with the Conservative franchise reform of 1885 , the ideological underpinnings of the Liberals' legislation also appeared to lead toward grander goals.

If Benjamin Disraeli's Second Reform Act of 1867 demonstrated the possibility of franchise reform's role in conservative state formation, William Gladstone's Third Reform Act of 1884 demonstrated the same possibility for liberal state formation. When Gladstone implemented his franchise legislation, he attempted to reverse the gains previously made by his rival Conservatives in enfranchising over one million more Britons. The Canadian Liberals' expansion of the franchise in 1898 did much the same thing. By enfranchising many of those Liberal voters excluded from the federal vote by the Conservatives in 1885 - including large numbers of newly-immigrated Canadians the Liberals successfully provided themselves with a much better opportunity for reelection. In doing so, they attempted to reverse whatever conservative gains the Conservatives made through their Electoral Franchise Act. With the Liberals' franchise 
reform apparently attempting to foster a stronger liberal political culture within Canada, the chances that the body politic would accept further liberal legislation also increased. The Liberal Franchise Act of 1898, therefore, promoted another ideological reorientation of the Canadian state: one that pushed aside conservative philosophy to make way for liberal policy.

Within the historiography on nineteenth-century Dominion franchise reform, the thrust of the analysis has centred on the dirty side of politics and the unsavoury partisan behaviour that reared its head perhaps too frequently during that era. From the chapter penned on "The Franchise" by political scientist Norman Ward in 1950 to historian Gordon Stewart's 1982 article on the Electoral Franchise Act as "John A. Macdonald's Greatest Triumph", scholars have tended to argue that nineteenth-century alterations to the federal franchise represented yet another set of power plays undertaken by Canada's political parties to both reward the party faithful and keep the reigns of power in the party's hands. Macdonald, "the old fox", is usually presented as the past master of this partisan sport. Undoubtedly, partisan desires played a role in franchise reform during this period. Aspects of the legislation, such as the revising barrister clause within the Electoral Franchise Act of 1885, provide historians with inviting examples of such political deviousness.

Yet, as this thesis has attempted to illustrate, partisanship only acted as one of several motivations for the franchise legislation enacted during the nineteenth century. In other words, it was a tail attached to the hind side of a larger whole. Notions of political progress and stability as well as various models of political paternalism also played prominent roles when politicians' minds turned to franchise reform. In 1867, 1885, and 
1898, however, one catalyst for Dominion franchise reform tended to hover above the others: that of political ideology. W. L. Morton introduced this idea in 1943 in perhaps the first scholarly analysis of nineteenth-century Dominion franchise development. Perceptively, he tied franchise reform to the implementation of political principles. More specifically, he viewed Conservative politicians and Liberal politicians employing the franchise as leverage in their larger contest over the nature of Confederation: whether Canada would have a strong central government, or whether political power would be diffused locally. Considering the date he wrote his article, however, Morton did not have the theoretical framework or tools to fully flesh out the implications of his argument. It is at this point that the concept of state formation - a theory suggesting that the state may transform a given culture through the conscious exercise of its amassed power in order to gain a cultural acceptance of itself and its goals - provides additional insight.

Undoubtedly, Conservatives and Liberals desired to introduce franchise legislation that flattered their own political ideals. Yet, in doing so, they did more than pass governance of the Dominion franchise back and forth between the provincial and federal spheres; they changed the size and composition of the nation's electorate itself. They opened and closed the shutter that composed their respective framing of the national politic. In selectively determining who may have the privilege to vote based upon perceived political proclivities, these politicians had the power to broadly shape an electorate best suited to achieve their own ends. While these ends ostensibly included the re-election of themselves and their fellow party members, they also included grander ideological designs for the country. Depending upon who a given piece of legislation enfranchised, Canadian statesmen, through the potential afforded by franchise reform to foster a given 
political culture within the body politic, could attempt to fashion a more conservative or more liberal Canadian state.

Herein lies the genius of the Dominion franchise reforms passed during the nineteenth century. Just as they reflected the act of pragmatic decision-making and played the dirty game of partisan politics, they also managed to evoke the language of good governance and to participate in the heady philosophical debates of Victorian politics. Above all else, however, these reforms gave Canadian statesmen, from John A. Macdonald and George-Etienne Cartier to George Brown and Wilfrid Laurier, a way to realize their own ideological visions of the Canadian nation. Contrary to contemporary opinion that Canada's politicians were 'wirepullers', franchise reform in the late nineteenth century elevated our politicians and invested them with altruism. They wished to help fashion the best nation possible, and they viewed the franchise as a means to achieving their higher ambitions. Although the success of these statesmen in attaining this lofty goal has yet to be fully measured - an investigation surely deserving of a paper of its own - their reforms certainly created the potential for such success. Today, the language of rights has overtaken the language of privilege regarding the franchise. With Canadians' right to vote enshrined within the nation's constitution, statesmen, like those of nineteenth-century Canada, no longer have the power to toy with franchise law in an attempt to fulfil their own national visions. That role has instead fallen directly to the Canadian voter. Men like Macdonald and Laurier, through their development of the Dominion franchise during the nineteenth century, sought to realize their own concepts of Confederation. Taking our inspiration from them, it is our task, as citizens of Canada, to now do the same. 


\section{Bibliography}

\section{Archival sources}

Library and Archives Canada

Edward Blake fonds, MG 27-ID2.

George Brown fonds, MG 24 B40.

Sir Charles Tupper fonds, MG 26-F.

Sir John A. Macdonald fonds, MG 26-A.

Sir Wilfrid Laurier fonds, MG 26-G.

Archives of Ontario

Sir James Pliny Whitney Papers, F 5-1.

\section{Primary sources}

Newspaper sources

Acadian Recorder. Halifax: Blackadar Bros.

Charlottetown Daily Examiner. Charlottetown: Examiner Pub. Co.

Courrier du Canada. Quebec: Léger Brousseau.

Daily British Colonist. Victoria: Colonist Publishers.

Grip. Toronto: Grip Print. \& Pub. Co.

La Presse. Montreal: T. Berthiaume.

Manitoba Daily Free Press. Winnipeg: W. F. Luxton (1873-1893); Clifford Sifton (1898-).

Montreal Daily Star. Montreal: Hugh Graham.

Novascotian. Halifax: William Annand. 
Palladium of Labor. Hamilton: s.n.

The Brandon Mail. Brandon, Man.: C. V. Cliffe.

The Daily Patriot. Charlottetown: s.n.

The Evening News. Toronto: E. E. Sheppard (1883-1887); William Douglas (1890?1902).

The Globe. Toronto: Globe Printing Co.

The Morning Chronicle. Halifax: C. Annand.

The Summerside Journal and Western Pioneer. Summerside, Prince Edward Island: Bertram and Bernard (1866-1895); W. A. Brennan (1895-1951).

The Telegram. Toronto: John Ross Robertson.

The Times. London, England: John Walter.

The Toronto World. Toronto: William Mclean.

The Victoria Daily Times. Victoria: s.n.

\section{Government documents}

British Columbia. The Revised Statutes of British Columbia 1897. Volume I. Victoria: Richard Wolfenden, Printer to the Queen's Most Excellent Majesty, 1897.

Canada. Bill. An Act to repeal the Electoral Franchise Act, and to further amend the Dominion Elections Act. Ottawa: S. E. Dawson, 1898.

-----. Census of Canada 1870-71. Volume III. Ottawa: I. B. Taylor, 1875.

-----. Official Report of the Debates of the House of Commons of the Dominion of Canada. Third session. Fifth Parliament. Volumes XVII - XIX. Ottawa: Maclean, Roger \& Co., 1885.

-----. Official Report of the Debates of the House of Commons of the Dominion of Canada. Third Session. Eighth Parliament. Volumes XLVI - XLVII. Ottawa: S. E. Dawson, 1898.

-----. The British North America act, 1867, and amending acts. Ottawa: s.n., 1890. 
Hodgins, Thomas. The Canadian Franchise Act, with Notes of Decisions on the Imperial Acts Relating to Registration, and on the Provincial Franchise and Election Acts. Toronto: Roswell \& Hutchison, 1886.

Manitoba. Acts of the Legislature of the Province of Manitoba passed in the session held in the Fifty-Fourth Year of The Reign of Her Majesty Queen Victoria, being the Fourth Session of the Seventh Legislature. Volume I. Winnipeg: David Philip, Queen's Printer, 1891.

Magurn, Arnott J., ed. The Parliamentary Guide and Work of General Reference 18981899. Winnipeg: The Manitoba Free Press Company, 1898.

New Brunswick. Acts of the General Assembly of Her Majesty's Province of New Brunswick. Fredericton: G. E. Fenety, 1889.

Nova Scotia. Debates and Proceedings of the House of Assembly, during the Second Session of the Twenty-Third Parliament of the Province of Nova Scotia 1865. Second session, twenty-third Parliament. Halifax: Crosskill and Bourinot, 1865.

-----. The Revised Statutes of Nova Scotia, 1900. Halifax: Queen's Printer, 1900.

------. The Statutes of Nova Scotia, passed in the Fourth Session of the General Assembly of the Twenty-sixth Reign of Her Majesty Queen Victoria, held on the Twelfth Day of February, 1863. Halifax: E. M. McDonald, Queen's Printer: 1863.

-----. The Statutes of Nova Scotia, passed in the Forty-Eighth Year of the Reign of Her Majesty Queen Victoria, being the Third Session of the Twenty-Eighth General Assembly Convened in the said Province. Halifax: Commissioner of Public Works and Mines, Queen's Printer: 1885.

Ontario. Statutes of the Province of Ontario, 55 Victoria, 1892. Toronto: Lud K. Cameron, 1892.

---.-. The Revised Statutes of Ontario, 1887. Volume I. Toronto: John Notman, 1887.

Province of Canada. First Report of the Secretary of the Board of Registration and Statistics, on the Census of the Canadas, for 1851-52. Volume I. Quebec: John Lovell, 1853.

------. Parliamentary Debates on the Subject of the Confederation of the British North American Provinces. Third Session. Eighth Provincial Parliament of Canada. Quebec: Hunter, Rose \& Co., 1865.

Quebec. Statutes of the Province of Quebec passed in the Fifty Ninth Year of the Reign of Her Majesty Queen Victoria and in the Fifth Session of the Eighth Legislature. Quebec: Charles François Langlois, 1895. 
Report of resolutions adopted at a conference of delegates from the provinces of Canada, Nova Scotia, and New Brunswick, and the colonies of Newfoundland and Prince Edward Island held at the city of Quebec, October 10, 1864, as the basis of a proposed confederation of those provinces and colonies. London: s.n., 1867 ?

United States. Ninth Census of the United States, 1870. Washington, D.C.: National Archives and Records Administration, 1870.

Other primary documents

Browne, G. P., ed. Documents on the Confederation of British North America. Toronto and Montreal: McClelland and Stewart, 1969.

Burke, Edmund. Reflections on the Revolution in France. Ed. J. C. D. Clark. Stanford: Stanford University Press, 2001.

-----. The Works of the Right Honourable Edmund Burke. London: John C. Nimmo, 1899.

Canadian Labor Congress. Proceedings of the Canadian Labor Congress, held in Toronto, On Wednesday, Thursday, and Friday, December $26^{\text {th }}, 27^{\text {th }}$, and $28^{\text {th }}$, 1883. Toronto: Roddy \& Nurse, 1884.

Catholic Church. The Encyclical Letter of Pope Pius LX, and the Syllabus of Modern Errors, Dated Dec. 8, 1864. S.I.: s.n., 1864.

-----. The Great Encyclical Letters of Pope Leo XIII. New York: Benzinger Brothers, 1903.

Elliott, Bruce S., ed. Index to the 1871 Census of Ontario: York. Toronto: Ontario Geneological Society, 1992.

Hobbes, Thomas. Leviathan. Ed. Edwin Curley. Indianapolis and Cambridge: Hackett, 1994.

"Joel Miller \& Brother, West Enterprise, November $25^{\text {th }}, 1869$, Produce Circular and Prices Current”. Toronto: s.n., 1869.

Laurier, Wilfrid, Sir. Discours a L'Étranger et au Canada. Montreal: Librairie Beauchemin, 1909.

Liberal-Conservative Union of Ontario. Handy Book on the Dominion Franchise Act. Second edition. Toronto: The Union, 1886. 
Liberal Party of Canada. Platform of the Liberal Party of Canada: Exemplified by Quotations, Tables and Arguments Based on Census and Trade Returns. Charlottetown: Geo. W. Gardiner, 1895.

Locke, John. Two Treatises of Government. Second edition. Cambridge: Cambridge University Press, 1967.

Mill, John Stuart. Considerations on Representative Government. Chicago: Gateway, 1962.

----. On Liberty. Ed. David Spitz. New York and London: W. W. Norton, 1975.

Montesquieu, Charles de Secondat, Baron de. The Spirit of the Laws. Volume 1. Trans. Thomas Nugent. New York: Hafner, 1949.

Smith, Goldwin. "The Proposed Constitution for British North America". Macmillan's Magazine 11 (March 1865): 406-416.

Tassé, Joseph. Discours de Sir Georges Cartier. Montreal: Eusèbe Senécal \& Fils, 1893.

Tocqueville, Alexis de. Democracy in America. Ed. J. P. Mayer. Trans. George Lawrence. New York: Harper and Row, 1988.

Trades and Labor Congress of Canada. Proceedings of the Trades and Labor Congress of Canada, held in Toronto, On Tuesday, Wednesday and Thursday, September $14^{\text {th }}, 15^{\text {th }} \& 16^{\text {th }}, 1886$. Toronto: Labor Record Print, 1886.

\section{Secondary sources}

Monographs

Adelman, Paul. Gladstone, Disraeli \& Later Victorian Politics. Third edition. London and New York: Longman, 1997.

Ajzenstat, Janet. The Canadian Founding: John Locke and Parliament. Montreal and Kingston: McGill-Queen's University Press, 2007.

Bacchi, Carol Lee. Liberation Deferred?: The Ideas of the English-Canadian Suffragists, 1877-1918. Toronto: University of Toronto Press, 1983.

Beck, J. Murray. Joseph Howe: Conservative Reformer 1804-1848. Volume 1. Montreal and Kingston: McGill-Queen's University Press, 1982.

-----. Pendulum of Power. Scarborough: Prentice-Hall, 1968. 
Berger, Carl. The Writing of Canadian History. Toronto: Oxford University Press, 1976.

Biagini, Eugenio F. British Democracy and Irish Nationalism 1876-1906. Cambridge: Cambridge University Press, 2007.

Billias, George Athan. Elbridge Gerry: Founding Father and Republican Statesman. Toronto and New York: McGraw-Hill, 1976.

Bradbury, Bettina. Working Families: Age, Gender, and Daily Survival in Industrializing Montreal. Toronto: University of Toronto Press, 2007.

Brock, Michael. The Great Reform Act. London: Hutchinson University Library, 1973.

Brown, Robert Craig and Cook, Ramsay. Canada 1896-1921: A Nation Transformed. Toronto: McClelland and Stewart, 1974.

Burchell, Graham, Colin Gordon, and Peter Miller, eds. The Foucault Effect: Studies in Governmentality with two lectures by and an interview with Michel Foucault. Chicago: University of Chicago Press, 1991.

Careless, J. M. S. Brown of the Globe: Statesman of Confederation 1860-1880.

Volume 2. Toronto: Macmillan, 1963.

Elections Canada. A History of the Vote in Canada. Ottawa: The Minister of Public Works and Government Services Canada, 1997.

Chamberlain, Joseph. A Political Memoir, 1880-1892. Ed. C. H. D. Howard. London: Batchworth Press, 1953.

Creighton, Donald. John A. Macdonald: The Old Chieftain. Toronto: Macmillan, 1955.

-----. John A. Macdonald: The Young Politician. Toronto: Macmillan, 1952.

Christian, William and Campbell, Colin. Political Parties and Ideologies in Canada. Third edition. Toronto: McGraw-Hill Ryerson, 1990.

Cleverdon, Catherine L. The Woman Suffrage Movement in Canada. Second edition. Toronto: University of Toronto Press, 1974.

Conrad, Margaret and Finkel, Alvin. Canada: A National History. Second edition. Toronto: Pearson Longman, 2007.

Corrigan, Philip and Sayer, Derek. The Great Arch. Oxford: Basil Blackwell, 1985.

Cowling, Maurice. 1867: Disraeli, Gladstone and Revolution. Cambridge: Cambridge University Press, 1967. 
Craig, F. W. S., ed. British Parliamentary Election Results 1832-1885. London: Macmillan, 1977.

Curtis, Bruce. The Politics of Population: State Formation, Statistics, and the Census of Canada, 1840-1875. Toronto: University of Toronto Press, 2001.

Durkheim, Emile. Professional Ethics and Civic Morals. Trans. Cornelia Brookfield. London: Routledge \& Kegan Paul, 1957.

Evans, A. Margaret. Sir Oliver Mowat. Toronto: University of Toronto Press, 1992.

Evans, Eric J. The Forging of the Modern State: Early industrial Britain 1783-1870. Third edition. Harlow: Pearson, 2001.

Foot, Paul. The Vote: How It was Won and How It was Undermined. London: Viking, 2005.

Forsey, Eugene. Trade Unions in Canada 1812-1902. Toronto: University of Toronto Press, 1982.

Foucault, Michel. Discipline and Punish. Trans. Alan Sheridan. New York: Vintage Books, 1995.

Garner, John. The Franchise and Politics in British North America 1755-1867. Toronto: University of Toronto Press, 1969.

Gramsci, Antonio. Prison Notebooks. Ed. and trans. Quintin Hoare and Geoffrey Nowell Smith. New York: International Publishers, 1971.

Grant, George. Lament for a Nation. Toronto: McClelland and Stewart, 1965.

Greer, Allan and Radforth, Ian, eds. Colonial Leviathan: State Formation in MidNineteenth-Century Canada. Toronto: University of Toronto Press, 1992.

Gwyn, Richard. John A.: the man who made us: the life and times of John A. Macdonald. Volume 1. Toronto: Random House Canada, 2007.

Gunn, Simon. History and Cultural Theory. Harlow: Pearson, 2006.

Hall, Catherine, Keith McClelland, and Jane Rendall. Defining the Victorian Nation: Class, Race, Gender and the Reform Act of 1867. Cambridge: Cambridge University Press, 2000.

Hardinge, Arthur, Sir. The Life of Henry Howard Molyneux Herbert Fourth Earl of Carnarvon 1831-1890. Volume 1. Ed. Elisabeth Countess of Carnarvon. London: Oxford University Press, 1925. 
Holland, Joe. Modern Catholic Social Teaching: The Popes Confront the Industrial Age 1740-1958. New York and Mahwah, New Jersey: Paulist Press, 2003.

Jackson, Alvin. Home Rule: An Irish History, 1800-2000. New York and Oxford: Oxford University Press, 2003.

Jenkins, T. A. Disraeli and Victorian Conservatism. New York: St. Martin's Press, 1997.

Jones, Andrew. The Politics of Reform 1884. Cambridge: Cambridge University Press, 1972.

Keyssar, Alexander. The Right To Vote. New York: Basic Books, 2000.

Knowles, Valerie. Strangers at Our Gates: Canadian Immigration and Immigration Policy, 1540-1990. Toronto and Oxford: Dundurn Press, 1992.

Langdon, Steven. The Emergence of the Canadian Working Class Movement 1845-1875. Toronto: New Hogtown Press, 1975.

Linteau, Paul-André, René Durocher, and Jean-Claude Robert. Quebec: A History 18671929. Trans. Robert Chodos. Toronto: James Lorimer, 1983.

Marx, Karl and Engels, Friedrich. The Marx-Engels Reader. Ed. Robert C. Tucker. Second edition. New York and London: W. W. Norton, 1978.

McNairn, Jeffrey L. The Capacity to Judge. Toronto: University of Toronto Press, 2000.

Monet, Jacques. The Last Cannon Shot. Toronto: University of Toronto Press, 1969.

Morton, Desmond. Working People. Fifth edition. Montreal and Kingston: McGillQueen's University Press, 2007.

Noel, S. J. R. Patrons, Clients, Brokers: Ontario Society and Politics, 1791-1896. Toronto: University of Toronto Press, 1990.

Palmer, Bryan D. Working Class Experience: Rethinking the History of Canadian Labour 1800-1991. Second edition. Toronto: McClelland and Stewart, 1992.

Pope, Joseph, Sir. Memoirs of the Right Honourable Sir John A. Macdonald. Volume II. Ottawa: J. Durie \& Son, 1894.

Read, Donald. Cobden and Bright: A Victorian Political Partnership. London: Edward Arnold, 1967.

Roper, Jon. Democracy and Its Critics. London: Unwin Hyman, 1989. 
Rutherford, Paul. A Victorian Authority. Toronto: University of Toronto Press, 1982.

Senior, Hereward. The Fenians and Canada. Toronto: Macmillan, 1978.

Simpson, Jeffrey. Spoils of Power. Toronto: Collins, 1988.

Skocpol, Theda. State and Social Revolutions. Cambridge and New York: Cambridge University Press, 1979.

Smith, Paul. Disraelian Conservatism and Social Reform. Toronto: University of Toronto Press, 1967.

Sotiron, Minko. From Politics to Profit. Montreal and Kingston: McGill-Queen's University Press, 1997.

Stevenson, Garth. Ex Uno Plures: Federal-Provincial Relations in Canada 1867-1896. Montreal and Kingston: McGill-Queen's University Press, 1993.

Sweeny, Alistair. George-Etienne Cartier: A Biography. Toronto: McClelland and Stewart, 1976.

Tassé, Joseph. Lord Beaconsfield and Sir John A. Macdonald: A Political and Personal Parallel. Trans. James Penny. Montreal: s.n., 1891.

-.---. Un Parallèle: Lord Beaconsfield et Sir John Macdonald. Ottawa: Imprimerie du Canada, 1880.

Taylor, Jeffrey. Fashioning Farmers: Ideology, Agricultural Knowledge, and the Manitoba Farm Movement, 1890-1925. Regina: Canadian Plains Research Centre, 1994.

Thompson, Michael, Richard Ellis, and Aaron Wildavsky. Cultural Theory. Boulder, San Fransisco, and Oxford: Westview Press, 1990.

Thomson, Dale C. Alexander Mackenzie: Clear Grit. Toronto: Macmillan, 1960.

Trevelyan, George Macaulay. British History in the Nineteenth Century (1782-1901). London, New York, and Toronto: Longmans, Green and Co., 1933.

Urquhart, M. C. and Buckley, K. A. H., eds. Historical Statistics of Canada. Toronto: Macmillan, 1965.

Vernon, James. Politics and the People: A study in English political culture, c. 18151867. Cambridge: Cambridge University Press, 1993.

Verzuh, Ron. Radical Rag. Ottawa: Steel Rail Publishing, 1988. 
Waite, P. B. Canada 1874-1896: Arduous Destiny. Toronto and Montreal: McClelland and Stewart, 1971.

Wallace, Elisabeth. Goldwin Smith, Victorian Liberal. Toronto: University of Toronto Press, 1957.

Ward, Norman. The Canadian House of Commons: Representation. Toronto: University of Toronto Press, 1950.

Weber, Max. Political Writings. Ed. Peter Lassman and Ronald Speirs. Cambridge: Cambridge University Press, 1994.

Wilson, David A. Thomas D'Arcy McGee: Passion, Reason, and Politics 1825-1857. Volume 1. Montreal and Kingston: McGill-Queen's University Press, 2008.

Wiseman, Nelson. In Search of Canadian Political Culture. Vancouver: University of British Columbia Press, 2007.

Wrong, George M. The Canadians: A Story of a People. Toronto: Macmillan, 1938.

\section{$\underline{\text { Articles and chapters }}$}

Acemoglu, Daren and Robinson, James A. "Why Did the West Extend the Franchise? Democracy, Inequality, and growth in Historical Perspective". The Quarterly Journal of Economics 115 (November 2000): 1167-1199.

Ajzenstat, Janet. "The Conservatism of the Canadian Founders". In After Liberalism: Essays in Search of Freedom, Virtue, and Order. Pages 17-32. Ed. William D. Gairdner. Toronto and New York: Stoddart, 1998.

Brady, Thomas. "Sinners and Publicans: Sir John A. Macdonald's Trial under the Controverted Elections Act, 1874." Ontario History 76.1: 65-87.

Brennan, J. William. "Wooing the 'Foreign Vote': Saskatchewan Politics and the Immigrant, 1905-1919”. Prairie Forum 3.1 (1978): 61-77.

Campbell, Gail G. "The Most Restrictive Franchise in British North America? A Case Study". Canadian Historical Review 71.2 (June 1990): 159-188.

Carty, R. Kenneth and Ward, W. Peter. "The Making of a Canadian Political Citizenship." In National Politics and Community in Canada. Pages 65-79. Eds. R. Kenneth Carty and W. Peter Ward. Vancouver: University of British Columbia Press, 1986. 
Chadwick, Mary E. J. "The Role of Redistribution in the Making of the Third Reform Act". The Historical Journal 19.3 (September 1976): 665-683.

Cornford, James. "The Transformation of Conservatism in the Nineteenth Century". Victorian Studies 7.1 (September 1963): 35-66.

Eadie, James A. "The Federal Election in Lennox Riding and Its Aftermath, 1882-83: A Glimpse of Victorian Political Morality." Ontario History 76.4: 353-373.

Ferry, Darren. "'Severing the Connections in a Complex Community': The Grange, the Patrons of Industry and the Construction/Contestation of a Late $19^{\text {th }}$-Century Agrarian Identity in Ontario". Labour/Le Travail 54 (Fall 2004): 9-47.

Forster, Ben, Davidson Malcolm, and Brown, R. Craig. "The Franchise, Personators, and Dead Men: An Inquiry into the Voters' Lists and the Election of 1891." Canadian Historical Review 67.1 (1986): 17-41.

Gwyn, Julian and Siddiq, Fazley. "Wealth Distribution in Nova Scotia during the Confederation Era, 1851 to 1871". Canadian Historical Review 73.4 (December 1992): 435-452.

Heaman, E. A. "Rights Talk and the Liberal Order Framework". In Liberalism and Hegemony: Debating the Canadian Liberal Revolution. Pages 147-175. Eds. Jean-François Constant and Michel Ducharme. Toronto: University of Toronto Press, 2009.

Himmelfarb, Gertrude. "The Politics of Democracy: the English Reform Act of 1867". Journal of British Studies 6.1 (1966): 97-138.

Hodgins, Bruce W. "The Canadian Political Elite's Attitudes Toward the Nature of the Plan of Union". In Federalism in Canada and Australia: The Early Years. Pages 43-59. Eds. Bruce W. Hodgins, Don Wright, and W. H. Heick. Waterloo: Wilfrid Laurier University Press, 1978.

Horowitz, Gad. "Conservatism, Liberalism, and Socialism in Canada: An Interpretation". Canadian Journal of Economy and Political Science 52.2 (May 1966): 143-171.

Langdon, Steven. "The Emergence of the Canadian Working Class Movement 18451875". Journal of Canadian Studies 8.2 (1973): 3-11.

Langdon, Steven. "The Emergence of the Canadian Working Class Movement 18451875". Journal of Canadian Studies 8.3 (1973): 8-26.

McKay, Ian. "The Liberal Order Framework: A Prospectus for a Reconnaissance of Canadian History". Canadian Historical Review 81.4 (December 2000): 617-645. 
Montgomery, Malcolm. "The Six Nations Indians and the Macdonald Franchise". Ontario History 57.1 (1965): 13-25.

Morton, W. L. "The Extension of the Franchise in Canada". Canadian Historical Association. Annual report of 1943: 104-115.

Ostry, Bernard. "Conservatives, Liberals, and Labour in the 1870's". Canadian Historical Review 41.2 (June 1960): 93-127.

-----. "Conservatives, Liberals, and Labour in the 1880s". Canadian Journal of Economics and Political Science 27.2 (May 1961): 141-161.

Ouellet, Fernand. "Through the Lace Curtain: Canadian View of American Democracy in the Pre-Civil War Period: Commentary". Canadian Association for American Studies bulletin 2.2 (1967): 69-72.

Palmer, Bryan D. "Labour Protest and Organization in Nineteenth-Century Canada, 1820-1890". Labour/Le Travail 20 (Fall 1987): 61-83.

Preece, Rod. "The Political Wisdom of Sir John A. Macdonald". Canadian Journal of Political Science 17.3 (September 1984): 459-486.

Smith, Andrew. "Toryism, Classical Liberalism, and Capitalism: The Politics of Taxation and the Struggle for Canadian Confederation". Canadian Historical Review 89.1 (March 2008): 2-25.

Smith, Peter J. "The Ideological Origins of Canadian Confederation". In Canada's Origins: Liberal, Tory, or Republican? Pages 47-78. Eds. Janet Ajzenstat and Peter J. Smith. Ottawa: Carleton University Press, 1995.

Snell, J. G. "The Cost of Living in Canada in 1870". Histoire Sociale: Social History 1979 12(23): 186-191.

Stephens, Hugh W. "The Changing Context of British Politics in the 1880s: Reform Acts and the Formation of the Liberal Unionist Party". Social Science History 1.4 (Summer 1977): 486-501.

Stewart, Gordon. “John A. Macdonald's Greatest Triumph.” Canadian Historical Review 63.1 (March 1982): 3-33.

Strong-Boag, Veronica. "The Citizenship Debates." In Contesting Canadian Citizenship. Pages 69-94. Eds. Robert Adamski, Dorothy E. Chunn, and Robert Menzies. Peterborough: Broadview Press, 2002.

Verberg, Norine. "Homeownership and Politics: Testing the Political Incorporation Thesis". Canadian Journal of Sociology 25.2 (2000): 169-195. 
Wise, S. F. "Upper Canada and the Conservative Tradition". In Profiles of a Province: Studies in the History of Ontario. Pages 20-33. Ed. Edith G. Firth. Toronto: Ontario Historical Society, 1967.

----. "Through the Lace Curtain: Canadian Views of American Democracy in the PreCivil War Period". Canadian Association for American Studies bulletin 2.2 (1967): 46-68.

\section{Dissertations and theses}

Banoub, David J. "Liberalism, Quebec's Political Culture, and George-Étienne Cartier, 1864-1871". M.A. thesis. Carleton University, 2007.

Franko, Roman Wasyl. "Toward a Liberal Democracy in Ontario: The Franchise and Policy-Making 1868-1888.” Ph.D. dissertation. Queen's University, 1992.

\section{Tertiary sources}

Borgatta, Edgar F. and Montgomery, Rhonda J. V., eds. Encyclopedia of Sociology. Volume 3. Second edition. New York: Macmillan Reference, 2000.

Cook, Ramsay, ed. Dictionary of Canadian Biography. Volume XIII. Toronto: University of Toronto Press, 1994.

----. Dictionary of Canadian Biography. Volume XIV. Toronto: University of Toronto Press, 1998.

-----. Dictionary of Canadian Biography. Volume XV. Toronto: University of Toronto Press, 2005.

Halpenny, Francess G., ed. Dictionary of Canadian Biography. Volume VI. Toronto: University of Toronto Press, 1987.

-----. Dictionary of Canadian Biography. Volume XI. Toronto: University of Toronto Press, 1982.

-----. Dictionary of Canadian Biography. Volume XII. Toronto: University of Toronto Press, 1990.

Johnson, Allan G. Blackwell Dictionary of Sociology. Second edition. Malden, Mass.: Blackwell, 2000.

La Terreur, Marc, ed. Dictionary of Canadian Biography. Volume X. Toronto: University of Toronto Press, 1972. 
Marsh, James H., ed. The Canadian Encyclopedia. Second edition. Volumes I-III. Edmonton: Hurtig, 1988.

Matthew, H.C.G. and Harrison, Brian, eds. Oxford Dictionary of National Biography. Volumes 7 and 12. New York and Oxford: Oxford University Press, 2004.

Morgan, Henry James, ed. The Canadian Men and Women of the Time. Toronto: William Briggs, 1912.

Ritzer, George, ed. The Blackwell Encyclopedia of Sociology. Volume VI. Malden, Mass.: Blackwell, 2007.

Scott, John and Marshall, Gordon, eds. A Dictionary of Sociology. Third edition. New York and Oxford: Oxford University Press, 2009.

Stearns, Peter N., ed. Encyclopedia of Social History. New York and London: Garland, 1994.

\section{$\underline{\text { Internet sources }}$}

Boultbee, Richard. "Alfred Boultbee (1828 - 1901)." The History of the Boultbee Family (2005), <http://homepage.ntlworld.com/boultbee/bfh/alfredb.htm > 17 October 2008). 